Tandem $N, N$-Dialkylation Reaction of $N$-Trimethylsilyl $\alpha$-Iminoesters Utilizing an Umpolung Reaction and Characteristics of the Silyl Substituent: Synthesis of Pyrrolidine, Piperidine, and Iminodiacetate

Isao Mizota, ${ }^{+}$Yurie Tadano, ${ }^{+}$Yusuke Nakamura, ${ }^{+}$Tomoki Haramiishi, ${ }^{+}$Miyuki Hotta, ${ }^{+}$ and Makoto Shimizu*,+,

${ }^{\dagger}$ Department of Chemistry for Materials, Graduate School of Engineering, Mie University, Tsu, Mie 514-8507, Japan.

${ }^{\ddagger}$ School of Energy Science and Engineering College, Nanjing Tech University, Nanjing 211800, Jiangsu Province, China

1. General Aspects S3

2. Synthesis of $N$-Silyl $\alpha$-Iminoester S3

2-1. Synthesis of Ketoester $-\mathrm{S3}$

2-2. [Table S1] Examination of Work-up for the Synthesis of $N$-Silyl $\alpha$-Iminoester----S7

2-3. Synthesis of $N$-Silyl $\alpha$-Iminoesters 1a-s$-S 7$

3. [Table 1] Examination of Solvents for $N$-Alkylation of $N$-Silyl $\alpha$-Iminoester$-S 17$

4. [Table S2] Examination of Nucleophiles for $N$-Alkylation of $N$-Silyl $\alpha$-Iminoester----S21

5. [Table S3] Examination of the Amount of Nucleophile for the $\mathrm{N}$-Alkylation of $\mathrm{N}$-Silyl $\alpha$-Iminoester $-S 24$

6. [Scheme 2] Scope of Substrates for $N$-Alkylation of $N$-Silyl $\alpha$-Iminoester $-S 25$

7. [Scheme 3] N-Addition of Enolate for $N$-Silyl $\alpha$-Iminoester S37 
8. Proposed Reaction Mechanism in the Presence of Silica gelS38

9. [Scheme 4 \& Table S4] Optimization of Tandem N-Alkylation/intramolecular Cyclization S39

10. [Scheme 5] Scope of Substrates for Tandem N-Alkylation/intramolecular Cyclization S42

11. [Table S5] Optimization of Tandem N-Alkylation/intermolecular Nucleophilic Addition S52

12. [Table 2] Tandem N,N-Dialkylation Reaction of $N$-Silyl $\alpha$-Iminoester$-S 55$

13. [Table S7] Computational Study of $N$-Silyl $\alpha$-Iminoester $-561$

14. References S101 


\section{General Aspects}

Infrared spectra were determined on a JASCO FT/IR-460 plus spectrometer. ${ }^{1} \mathrm{H}$ NMR and ${ }^{13} \mathrm{C}$ NMR spectra were recorded with a JEOL ECX-400P, or a JEOL A-500 spectrometer using tetramethylsilane as an internal standard. Mass spectra were recorded on a JEOL MS-700D spectrometer. Propionitrile (EtCN) and acetonitrile (MeCN) were distilled from phosphorus pentaoxide and then from calcium hydride and stored over Molecular Sieves 4Å. Dimethyl sulfoxide (DMSO), dimethyl formamide (DMF), dichloromethane $\left(\mathrm{CH}_{2} \mathrm{Cl}_{2}\right)$, and dichloroethane $\left(\mathrm{C}_{2} \mathrm{H}_{4} \mathrm{Cl}_{2}\right)$ were distilled from calcium hydride and stored over Molecular Sieves $4 \AA \AA$. Toluene was dried over calcium chloride, distilled, and stored over Molecular Sieves $4 \AA \AA$. Hexane was distilled and stored over sodium. Diethylether $\left(\mathrm{Et}_{2} \mathrm{O}\right)$ and tetrahydrofuran (THF) were distilled from benzophenone ketyl immediately before use or purified by Glass Contour Organic Solvent Purification System of Nikko Hansen \& Co., Ltd. Dimethoxyethane (DME) was distilled from calcium hydride and then cupper (I) chloride and stored over sodium. 1,4-Dioxane was distilled from calcium hydride and stored over sodium. Cyclopentyl methyl ether (CPME), tert-butyl methyl ether (TBME), and 2-methyltetrahydrofuran (2-MeTHF) were distilled before use. Purification of products was performed by column chromatography on silica gel (Kanto Silica Gel 60N) and/or preparative TLC on silica gel (Merck Kiesel Gel GF254 or Wako Gel B-5F).

\section{Synthesis of $\boldsymbol{N}$-Silyl $\alpha$-Iminoester}

\section{2-1. Synthesis of Ketoester}

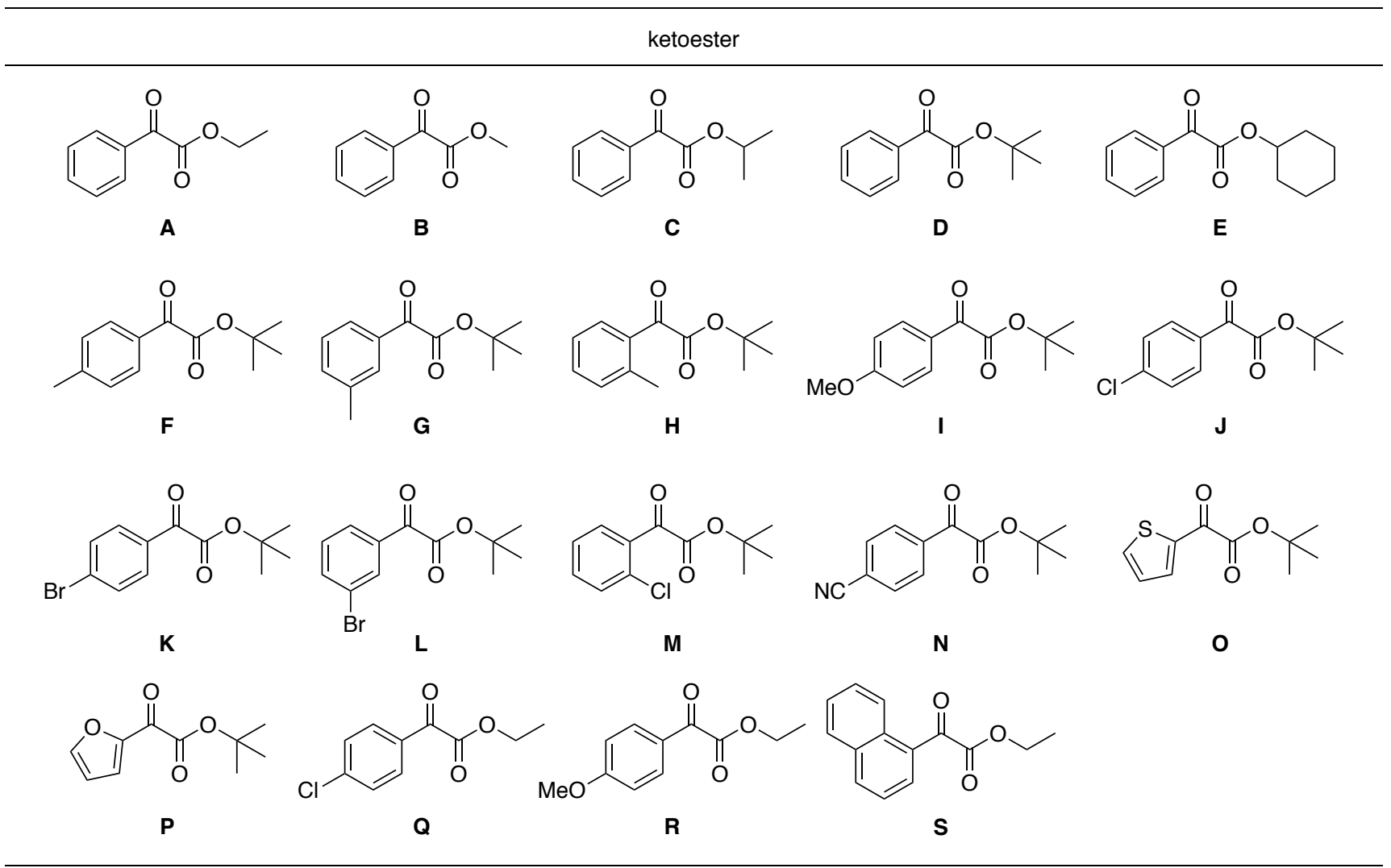

Compounds A and B were purchased from Tokyo Chemical Industry Co., Ltd. or FUJIFILM Wako Pure Chemical Corporation. Compounds $\mathbf{C}-\mathbf{K}, \mathbf{M}, \mathbf{O}$, and $\mathbf{Q}-\mathbf{S}$ were prepared according to the reported procedures. $^{1-6}$ 
<smiles>CC(=O)c1cccc(Br)c1</smiles>

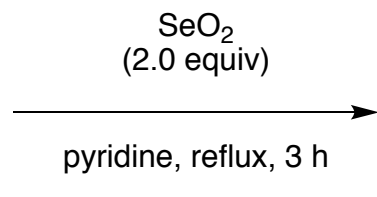<smiles>O=C(O)C(=O)c1cccc(Br)c1</smiles>

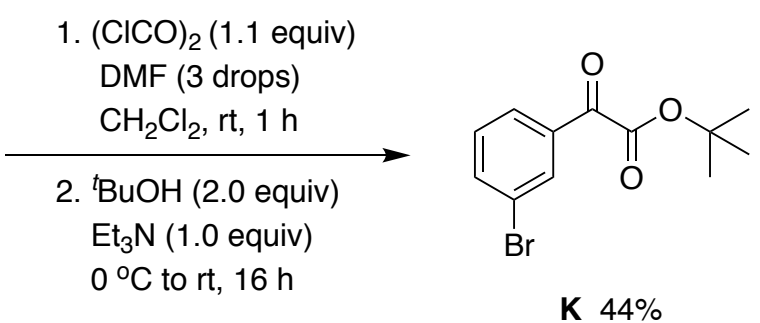

In a $30 \mathrm{~mL}$ two-necked round-bottomed flask equipped with a magnetic stirring bar, a rubber septum, and an argon balloon were placed $\mathrm{SeO}_{2}(2.22 \mathrm{~g}, 20 \mathrm{mmol}, 2.0$ equiv) and 3'-bromoacetophenone $(1.4 \mathrm{~mL}, 10 \mathrm{mmol})$ in pyridine $(5.0 \mathrm{~mL})$ and the whole mixture was heated at reflux for $3 \mathrm{~h}$. After the reaction, the mixture was filtered with suction through a celite pad and concentrated in vacuo. The resulting residue was treated with $2 \mathrm{~N} \mathrm{NaOH}$ aq. $(20 \mathrm{~mL})$ and the mixture was extracted with ethyl acetate $(20 \mathrm{~mL})$. The aqueous layer was acidified using $2 \mathrm{~N} \mathrm{HCl}$ aq. to $\mathrm{pH} 1$ and extracted with ethyl acetate $(20 \mathrm{~mL} \times 3)$. The combined organic phases were dried $\left(\mathrm{Na}_{2} \mathrm{SO}_{4}\right)$, and concentrated in vacuo to give a crude product, which was recrystallized from $\mathrm{CH}_{2} \mathrm{Cl}_{2}$ /hexane to give 2-(3-bromophenyl)-2-oxoacetic acid (965 mg, 42\%).

Under an argon atmosphere, a suspension of 2-(3-bromophenyl)-2-oxoacetic acid (916 mg, 4.00 $\mathrm{mmol})$ in $\mathrm{CH}_{2} \mathrm{Cl}_{2}(5.0 \mathrm{~mL})$ was stirred at room temperature for $5 \mathrm{~min}$, and to it was added oxalyl chloride (0.39 mL, $4.40 \mathrm{mmol}, 1.1$ equiv) and DMF ( 3 drops) slowly. After stirring for $1 \mathrm{~h}$, the mixture was concentrated in vacuo and cooled to $0{ }^{\circ} \mathrm{C}$, and to it was added $\mathrm{CH}_{2} \mathrm{Cl}_{2}(5.0 \mathrm{~mL}),{ }^{t} \mathrm{BuOH}(0.76 \mathrm{~mL}$, $8.00 \mathrm{mmol}, 2.0$ equiv) and $\mathrm{Et}_{3} \mathrm{~N}(0.56 \mathrm{~mL}, 4.00 \mathrm{mmol}, 1.0$ equiv). After the mixture was stirred for 16 $h$, the reaction was quenched with $\mathrm{H}_{2} \mathrm{O}(5.0 \mathrm{~mL})$, and the whole mixture was extracted with $\mathrm{CH}_{2} \mathrm{Cl}_{2}$ $(10.0 \mathrm{~mL} \times 3)$. The combined organic phases were washed with brine $(15 \mathrm{~mL})$, dried over anhydrous $\mathrm{Na}_{2} \mathrm{SO}_{4}$, and concentrated in vacuo. The crude product was purified by column chromatography on silica gel ( $n$-hexane/ethyl acetate $=7 / 1$ ) to give the title compound L (504 mg, 44\%).

tert-Butyl 2-(3-bromophenyl)-2-oxoacetate (L)<smiles>CC(C)(C)OC(=O)C(=O)c1cccc(Br)c1</smiles>

Yield 44\%; Yellow oil; ${ }^{1} \mathrm{H}$ NMR $\left(500 \mathrm{MHz}, \mathrm{CDCl}_{3}\right) \delta$ 8.13-8.12 (m, $\left.1 \mathrm{H}\right), 7.91-7.89(\mathrm{~m}, 1 \mathrm{H})$, 7.78-7.76 (m, 1H), 7.41-7.37 (m, 1H), $\left.1.64(\mathrm{~s}, 9 \mathrm{H}) ;{ }^{13} \mathrm{C} \mathrm{NMR} \mathrm{(125} \mathrm{MHz,} \mathrm{CDCl}_{3}\right) \delta 185.2,162.8,137.4,134.3,132.6$, $130.4,128.5,123.0,85.2,28.0$; IR (neat) 3090, 2984, 2979, 2939, 1731, 1693, 1587, 1484, 1398, 1371, 1213, 1153, 1070, 988, $857 \mathrm{~cm}^{-1}$; HRMS (EI): Calcd for $\mathrm{C}_{12} \mathrm{H}_{13} \mathrm{BrO}_{3}(\mathrm{M})^{+} 284.0048$, found 284.0049 .

\section{Synthesis of tert-butyl 2-(4-cyanophenyl)-2-oxoacetate (N)}



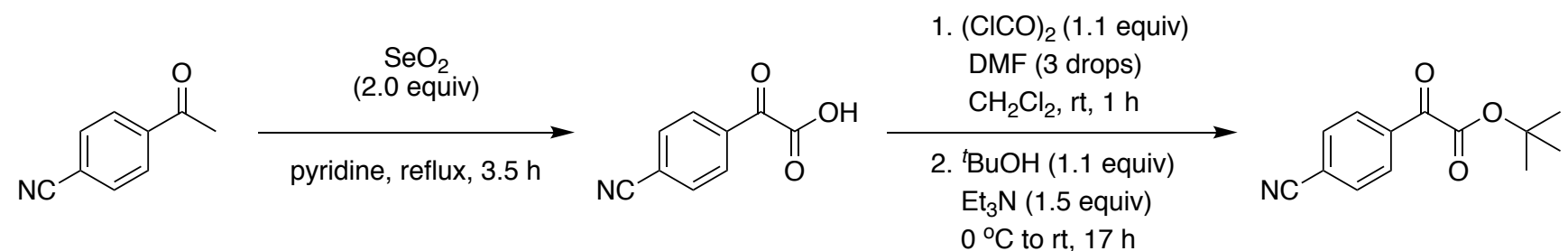

N 2\% (2 steps)

In a $30 \mathrm{~mL}$ two-necked round-bottomed flask equipped with a magnetic stirring bar, a rubber septum, and an argon balloon were placed $\mathrm{SeO}_{2}(2.22 \mathrm{~g}, 20 \mathrm{mmol}, 2.0$ equiv) and 4'-cyanoacetophenone $(1.45 \mathrm{~g}, 10 \mathrm{mmol})$ in pyridine $(5.0 \mathrm{~mL})$ and the whole mixture was heated at reflux for $3.5 \mathrm{~h}$. After the reaction, the mixture was filtered with suction through a celite pad and concentrated in vacuo. The resulting residue was treated with $2 \mathrm{~N} \mathrm{NaOH}$ aq. $(20 \mathrm{~mL})$ and the mixture was extracted with ethyl acetate $(20 \mathrm{~mL})$. The aqueous layer was acidified using $2 \mathrm{~N} \mathrm{HCl}$ aq. to $\mathrm{pH} 1$ and extracted with ethyl acetate $(20 \mathrm{~mL} \times 3)$. The combined organic phases were dried $\left(\mathrm{Na}_{2} \mathrm{SO}_{4}\right)$, and concentrated in vacuo to give a crude product $(905 \mathrm{mg})$, which was used without further purification.

Under an argon atmosphere, a suspension of crude product ( $905 \mathrm{mg}, 5.10 \mathrm{mmol}$ ) in $\mathrm{CH}_{2} \mathrm{Cl}_{2}(5.0 \mathrm{~mL}$ ) was stirred at room temperature for $5 \mathrm{~min}$, and to it was added oxalyl chloride $(0.44 \mathrm{~mL}, 5.10 \mathrm{mmol}$, 1.0 equiv) and DMF ( 3 drop) slowly. After stirring for $1 \mathrm{~h}$, the mixture was concentrated in vacuo and cooled to $0{ }^{\circ} \mathrm{C}$, and to it was added $\mathrm{CH}_{2} \mathrm{Cl}_{2}(5.0 \mathrm{~mL}),{ }^{t} \mathrm{BuOH}\left(0.53 \mathrm{~mL}, 5.60 \mathrm{mmol}, 1.1\right.$ equiv) and $\mathrm{Et}_{3} \mathrm{~N}$ $(1.0 \mathrm{~mL}, 7.70 \mathrm{mmol}, 1.5$ equiv). After the mixture was stirred for $17 \mathrm{~h}$, the reaction was quenched with $\mathrm{H}_{2} \mathrm{O}(5.0 \mathrm{~mL})$, and the whole mixture was extracted with $\mathrm{CH}_{2} \mathrm{Cl}_{2}(10.0 \mathrm{~mL} \times 3)$. The combined organic phases were washed with brine $(15 \mathrm{~mL})$, dried over anhydrous $\mathrm{Na}_{2} \mathrm{SO}_{4}$, and concentrated in vacuo. The crude product was purified by column chromatography on silica gel ( $n$-hexane/ethyl acetate $=7 / 1)$ to give the title compound $\mathbf{N}(45.0 \mathrm{mg}, 2 \%$ (2 steps)).

tert-Butyl 2-(4-cyanophenyl)-2-oxoacetate (N)<smiles>CC(C)(C)OC(=O)C(=O)c1ccc(C#N)cc1</smiles>

Yield 2\% (2 steps); Yellow oil; ${ }^{1} \mathrm{H}$ NMR (400 MHz, $\left.\mathrm{CDCl}_{3}\right) \delta 8.12-8.09(\mathrm{~m}, 2 \mathrm{H}), 7.83-7.80(\mathrm{~m}, 2 \mathrm{H}), 1.64(\mathrm{~s}$, $9 \mathrm{H}) ;{ }^{13} \mathrm{C} \mathrm{NMR}\left(100 \mathrm{MHz}, \mathrm{CDCl}_{3}\right) \delta 184.9,162.2,135.7,132.6,130.3,117.7,117.6,85.6,28.0$; IR (neat) 2982, 2232, 1727, 1696, 1328, 1211, 1150, 987, 866, 829, $791 \mathrm{~cm}^{-1}$; HRMS (EI): Calcd for $\mathrm{C}_{13} \mathrm{H}_{13} \mathrm{NO}_{3}$ $(\mathrm{M})^{+}$231.0895, found 231.0889 .

\section{Synthesis of tert-butyl 2-(furan-2-yl)-2-oxoacetate (P)}
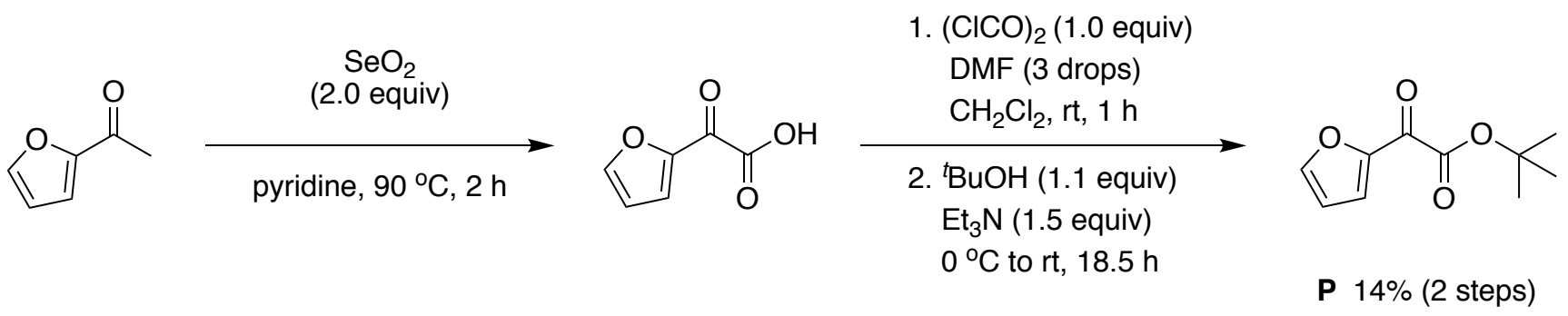
In a $30 \mathrm{~mL}$ two-necked round-bottomed flask equipped with a magnetic stirring bar, a rubber septum, and an argon balloon were placed $\mathrm{SeO}_{2}(2.22 \mathrm{~g}, 20 \mathrm{mmol}, 2.0$ equiv) and 2-acetylfuran (1.0 $\mathrm{mL}, 10 \mathrm{mmol}$ ) in pyridine $(5.0 \mathrm{~mL})$ and the whole mixture was heated at $90{ }^{\circ} \mathrm{C}$ for $2 \mathrm{~h}$. After the reaction, the mixture was filtered with suction through a celite pad and concentrated in vacuo. The resulting residue was treated with $2 \mathrm{~N} \mathrm{NaOH}$ aq. $(20 \mathrm{~mL})$ and the mixture was extracted with ethyl acetate $(20 \mathrm{~mL})$. The aqueous layer was acidified using $2 \mathrm{~N} \mathrm{HCl}$ aq. to $\mathrm{pH} 1$ and extracted with ethyl acetate $(20 \mathrm{~mL} \times 3)$. The combined organic phases were dried $\left(\mathrm{Na}_{2} \mathrm{SO}_{4}\right)$, and concentrated in vacuo to give a crude product (492 $\mathrm{mg}$ ), which was used without further purification.

Under an argon atmosphere, a suspension of crude product ( $492 \mathrm{mg}, 3.51 \mathrm{mmol}$ ) in $\mathrm{CH}_{2} \mathrm{Cl}_{2}(5.0 \mathrm{~mL}$ ) was stirred at room temperature for $5 \mathrm{~min}$, and to it was added oxalyl chloride $(0.30 \mathrm{~mL}, 3.51 \mathrm{mmol}$, 1.0 equiv) and DMF ( 3 drops) slowly. After stirring for $1 \mathrm{~h}$, the mixture was concentrated in vacuo and cooled to $0{ }^{\circ} \mathrm{C}$, and to it was added $\mathrm{CH}_{2} \mathrm{Cl}_{2}(5.0 \mathrm{~mL}),{ }^{t} \mathrm{BuOH}\left(0.37 \mathrm{~mL}, 3.86 \mathrm{mmol}, 1.1\right.$ equiv) and $\mathrm{Et}_{3} \mathrm{~N}$ $(0.73 \mathrm{~mL}, 5.27 \mathrm{mmol}, 1.5$ equiv). After the mixture was stirred for $18.5 \mathrm{~h}$, the reaction was quenched with $\mathrm{H}_{2} \mathrm{O}(5.0 \mathrm{~mL})$, and the whole mixture was extracted with $\mathrm{CH}_{2} \mathrm{Cl}_{2}(10.0 \mathrm{~mL} \times 3)$. The combined organic phases were washed with brine $(15 \mathrm{~mL})$, dried over anhydrous $\mathrm{Na}_{2} \mathrm{SO}_{4}$, and concentrated in vacuo. The crude product was purified by column chromatography on silica gel ( $n$-hexane/ethyl acetate $=7 / 1)$ to give the title compound $\mathbf{P}(283.5 \mathrm{mg}, 14 \%$ (2 steps)).

tert-Butyl 2-(furan-2-yl)-2-oxoacetate (P)

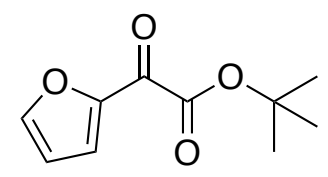

Yield 14\% (2 steps); Yellow oil; ${ }^{1} \mathrm{H}$ NMR (400 MHz, $\left.\mathrm{CDCl}_{3}\right) \delta$ 7.75-7.74 (m, $\left.1 \mathrm{H}\right), 7.61(\mathrm{~d}, J=3.7 \mathrm{~Hz}, 1 \mathrm{H})$, 6.62 (dd, $J=1.4,3.7 \mathrm{~Hz}, 1 \mathrm{H}), 1.62(\mathrm{~s}, 9 \mathrm{H}) ;{ }^{13} \mathrm{C} \mathrm{NMR}\left(100 \mathrm{MHz}, \mathrm{CDCl}_{3}\right) \delta 172.5,160.6,149.8,149.1$, 123.8, 112.8, 84.6, 27.8; IR (neat) 1730, 1675, 1464, 1373, 1248, 1155, 1030, 995, 909, 885, 839, 771 $\mathrm{cm}^{-1}$; HRMS (EI): Calcd for $\mathrm{C}_{10} \mathrm{H}_{12} \mathrm{O}_{4}(\mathrm{M})^{+} 196.0736$, found 196.0741 . 


\section{2-2. [Table S1] Examination of Work-up for the Synthesis of $N$-Silyl $\alpha$-Iminoester}

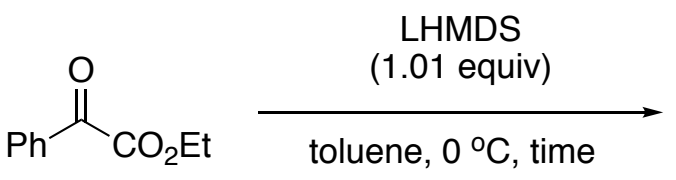

A<smiles>CCOC(=O)/C(=N\N(C)S(C)(=O)=O)c1ccccc1</smiles>

1a

\begin{tabular}{ccccc}
\hline entry & $c[\mathrm{M}]$ & time $(\mathrm{h})$ & work-up & yield $(\%)$ \\
\hline 1 & 0.015 & 1 & washed with $\mathrm{H}_{2} \mathrm{O}$ & decomposed \\
2 & 0.015 & 1 & distillation & decomposed \\
3 & 0.015 & 1 & washed with $\mathrm{H}_{2} \mathrm{O}$ and $\mathrm{NaHCO}_{3}$ aq. & decomposed \\
4 & 0.015 & 2.5 & washed with buffer & decomposed \\
5 & 0.003 & 13.5 & washed with $\mathrm{H}_{2} \mathrm{O}$ & 98 \\
\hline
\end{tabular}

(Table S1, entry 5)

Under an argon atmosphere, a solution of ketoester $\mathbf{A}(1.6 \mathrm{~mL}, 10.0 \mathrm{mmol})$ in toluene $(50 \mathrm{~mL})$ was stirred at $0{ }^{\circ} \mathrm{C}$ for $5 \mathrm{~min}$, and to it was added LHMDS in THF $(7.8 \mathrm{~mL}, 10.1 \mathrm{mmol}, 1.30 \mathrm{~N}, 1.01$ equiv) slowly. After the mixture was stirred for $13.5 \mathrm{~h}$ at $0{ }^{\circ} \mathrm{C}$, the reaction was quenched with $\mathrm{H}_{2} \mathrm{O}(5.0 \mathrm{~mL})$, and the whole mixture was washed with $\mathrm{H}_{2} \mathrm{O}(5.0 \mathrm{~mL} \times 3)$, dried over anhydrous $\mathrm{Na}_{2} \mathrm{SO}_{4}$, and concentrated in vacuo to give ethyl (Z)-2-phenyl-2-[(trimethylsilyl)imino]acetate 1a (2.44 g).

Ethyl (Z)-2-phenyl-2-[(trimethylsilyl)imino]acetate (1a) ${ }^{7}$<smiles>CCOC(=O)/C(=N\[Si](C)(C)C)c1ccccc1</smiles>

Yield 98\%; Yellow oil; ${ }^{1} \mathrm{H}$ NMR $\left(500 \mathrm{MHz}, \mathrm{CDCl}_{3}\right) \delta$ 7.77-7.76 (m, 2H), 7.47-7.39 (m, 3H), 4.35 (q, J = 7.3 $\mathrm{Hz}, 2 \mathrm{H}), 1.39(\mathrm{t}, \mathrm{J}=7.3 \mathrm{~Hz}, 3 \mathrm{H}), 0.24(\mathrm{~s}, 9 \mathrm{H}) ;{ }^{13} \mathrm{C} \mathrm{NMR}\left(100 \mathrm{MHz}, \mathrm{CDCl}_{3}\right) \delta$ 166.3, 164.7, 136.3, 131.4, 128.4, 127.6, 61.3, 14.1, -0.3; IR (neat) 3027, 2960, 1731, 1667, 1366, 1314, 1277, 1248, 1196, 760 $\mathrm{cm}^{-1}$; HRMS (EI): Calcd for $\mathrm{C}_{13} \mathrm{H}_{19} \mathrm{NO}_{2} \mathrm{Si}(\mathrm{M})^{+} 249.1185$, found 249.1181 .

\section{2-3. Synthesis of $\boldsymbol{N}$-Silyl $\alpha$-Iminoester 1a-s}


<smiles>CCOC(=O)/C(=N\C(C)C)c1ccccc1</smiles>

1a

$1 b$

$1 c$

$1 d$

$1 e$<smiles>Cc1ccc(/C(=N/[Y5](=O)[O-])C(=O)OC(C)(C)C)cc1</smiles><smiles>Cc1ccccc1/C(=N/NS(C)(=O)=O)C(=O)OC(C)(C)C</smiles>

$1 \mathrm{~h}$<smiles>COc1ccc(/C(=N/NS(C)(=O)=O)C(=O)OC(C)(C)C)cc1</smiles>

$1 \mathrm{i}$<smiles></smiles>

1j<smiles>CC(C)(C)OC(=O)C(=NNS(C)(=O)=O)c1cccc(Br)c1</smiles><smiles></smiles><smiles>CC(C)(C)OC(=O)C(=NNS(C)(=O)=O)c1ccc(C#N)cc1</smiles><smiles>CN(C)/N=C(\C(=O)OC(C)(C)C)c1cccs1</smiles>

$1 \mathrm{k}$

11

$1 \mathrm{~m}$

$1 n$

10<smiles>CN(C)/N=C(\C(=O)OC(C)(C)C)c1ccco1</smiles><smiles>CCOC(=O)/C(=N\N(C)S(C)(=O)=O)c1ccc(Cl)cc1</smiles>

19<smiles>CCOC(=O)C(=NN(C)S(=O)(=O)c1ccc(OC)cc1)C(=O)OCC</smiles><smiles>CCOC(=O)C(=NN(C)S(=O)(=O)c1cccc2ccccc12)C(=O)OCC</smiles>

$1 p$

$1 r$

$1 \mathrm{~s}$

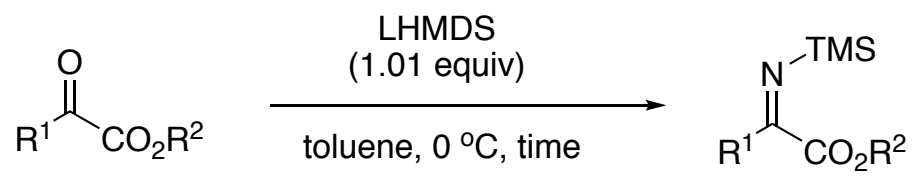

\begin{tabular}{|c|c|c|c|c|c|c|}
\hline \multirow[b]{2}{*}{ entry } & \multirow[b]{2}{*}{$\mathrm{R}^{1}$} & \multirow[b]{2}{*}{$\mathrm{R}^{2}$} & \multicolumn{4}{|c|}{1} \\
\hline & & & ketoester & time $(\mathrm{h})$ & product & yield (\%) \\
\hline 1 & $\mathrm{Ph}$ & Et & $A$ & 13.5 & $1 a$ & 98 \\
\hline 2 & $\mathrm{Ph}$ & $\mathrm{Me}$ & B & 3 & $1 b$ & 64 \\
\hline 3 & $\mathrm{Ph}$ & iPr & C & 3 & 1c & 98 \\
\hline 4 & $\mathrm{Ph}$ & $t^{\mathrm{B} u}$ & D & 3 & $1 d$ & 87 \\
\hline 5 & $\mathrm{Ph}$ & Cy & E & 1 & $1 e$ & 83 \\
\hline 6 & $4-\mathrm{MeC}_{6} \mathrm{H}_{4}$ & ${ }^{t} \mathrm{Bu}$ & $F$ & 3 & $1 f$ & 85 \\
\hline 7 & $3-\mathrm{MeC}_{6} \mathrm{H}_{4}$ & $t^{\mathrm{Bu}}$ & $\mathbf{G}$ & 1 & $1 \mathrm{~g}$ & 99 \\
\hline 8 & 2- $\mathrm{MeC}_{6} \mathrm{H}_{4}$ & $t^{t} \mathrm{Bu}$ & H & 3.5 & $1 \mathrm{~h}$ & 92 \\
\hline 9 & 4- $\mathrm{MeOC}_{6} \mathrm{H}_{4}$ & $t^{\mathrm{Bu}}$ & I & 2 & $1 \mathrm{i}$ & 99 \\
\hline 10 & 4- $-\mathrm{ClC}_{6} \mathrm{H}_{4}$ & $t^{\mathrm{Bu}}$ & $\mathbf{J}$ & 2 & $1 \mathrm{j}$ & quant \\
\hline 11 & 4- $\mathrm{BrC}_{6} \mathrm{H}_{4}$ & ${ }^{t} \mathrm{Bu}$ & $K$ & 2.5 & $1 \mathrm{k}$ & quant \\
\hline 12 & $3-\mathrm{BrC}_{6} \mathrm{H}_{4}$ & $t^{\mathrm{Bu}}$ & $\mathbf{L}$ & 1.5 & 11 & 97 \\
\hline 13 & $2-\mathrm{ClC}_{6} \mathrm{H}_{4}$ & $t^{\mathrm{Bu}}$ & $\mathbf{M}$ & 3.5 & $1 \mathrm{~m}$ & 92 \\
\hline 14 & $4-\mathrm{CNC}_{6} \mathrm{H}_{4}$ & ${ }^{t} \mathrm{Bu}$ & $\mathbf{N}$ & 5 & $1 n$ & 69 \\
\hline 15 & 2-Thienyl & ${ }^{t} \mathrm{Bu}$ & 0 & 2 & 10 & 92 \\
\hline 16 & 2-Furyl & $t^{\mathrm{Bu}}$ & $\mathbf{P}$ & 2 & $1 p$ & 94 \\
\hline 17 & $4-\mathrm{ClC}_{6} \mathrm{H}_{4}$ & Et & $\mathbf{Q}$ & 2 & $1 q$ & 96 \\
\hline 18 & 4- $\mathrm{MeOC}_{6} \mathrm{H}_{4}$ & Et & $\mathbf{R}$ & 4.5 & $1 \mathrm{r}$ & quant \\
\hline 19 & 1-Naphthyl & $\mathrm{Et}$ & $\mathrm{s}$ & 2 & $1 \mathrm{~s}$ & 81 \\
\hline
\end{tabular}




\section{Synthesis of methyl (Z)-2-phenyl-2-[(trimethylsilyl)imino]acetate (1b)}

Under an argon atmosphere, a solution of ketoester $\mathbf{B}(1.4 \mathrm{~mL}, 10.0 \mathrm{mmol})$ in toluene $(50 \mathrm{~mL})$ was stirred at $0{ }^{\circ} \mathrm{C}$ for $5 \mathrm{~min}$, and to it was added LHMDS in THF (7.8 mL, $10.1 \mathrm{mmol}, 1.30 \mathrm{~N}, 1.01$ equiv) slowly. After the mixture was stirred for $3 \mathrm{~h}$ at $0{ }^{\circ} \mathrm{C}$, the reaction was quenched with $\mathrm{H}_{2} \mathrm{O}(5.0 \mathrm{~mL})$, and the whole mixture was washed with $\mathrm{H}_{2} \mathrm{O}(5.0 \mathrm{~mL} \times 3)$, dried over anhydrous $\mathrm{Na}_{2} \mathrm{SO}_{4}$, and concentrated in vacuo to give the title compound $\mathbf{1 b}(2.26 \mathrm{~g})$.

Methyl (Z)-2-phenyl-2-[(trimethylsilyl)imino]acetate (1) ${ }^{8}$

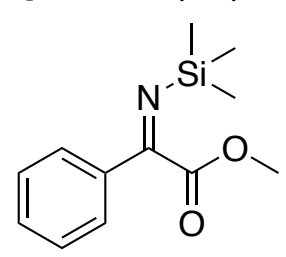

Yield 64\%; Yellow oil; ${ }^{1} \mathrm{H}$ NMR (400 MHz, $\left.\mathrm{CDCl}_{3}\right) \delta$ 7.77-7.74 (m, 2H), 7.47-7.37 (m, 3H), $3.86(\mathrm{~s}, 3 \mathrm{H})$, 0.23 (s, 9H); ${ }^{13} \mathrm{C}$ NMR (100 MHz, $\left.\mathrm{CDCl}_{3}\right) \delta 166.5,164.3,136.1,131.4,128.4,127.6,51.8,-0.45 ; \mathrm{IR}$ (neat) 3061, 2955, 2900, 1737, 1666, 1248, 1202, 1174, 1007, 966, 843, $693 \mathrm{~cm}^{-1}$; HRMS (EI): Calcd for $\mathrm{C}_{12} \mathrm{H}_{17} \mathrm{NO}_{2} \mathrm{Si}(\mathrm{M})^{+} 235.1029$, found 235.1034.

\section{Synthesis of isopropyl (Z)-2-phenyl-2-[(trimethylsilyl)imino]acetate (1c)}

Under an argon atmosphere, a solution of ketoester C (209 $\mathrm{mg}, 1.09 \mathrm{mmol})$ in toluene $(5.0 \mathrm{~mL})$ was stirred at $0{ }^{\circ} \mathrm{C}$ for $5 \mathrm{~min}$, and to it was added LHMDS in THF ( $0.84 \mathrm{~mL}, 1.10 \mathrm{mmol}, 1.30 \mathrm{~N}, 1.01$ equiv) slowly. After the mixture was stirred for $3 \mathrm{~h}$ at $0{ }^{\circ} \mathrm{C}$, the reaction was quenched with $\mathrm{H}_{2} \mathrm{O}(5.0 \mathrm{~mL})$, and the whole mixture was washed with $\mathrm{H}_{2} \mathrm{O}(5.0 \mathrm{~mL} \times 3)$, dried over anhydrous $\mathrm{Na}_{2} \mathrm{SO}_{4}$, and concentrated in vacuo to give the title compound $1 \mathrm{c}(281 \mathrm{mg})$.

Isopropyl (Z)-2-phenyl-2-[(trimethylsilyl)imino]acetate (1c)<smiles>CC(C)OC(=O)/C(=N\[Si](C)(C)C)c1ccccc1</smiles>

Yield 98\%; Yellow oil; ${ }^{1} \mathrm{H}$ NMR (400 MHz, $\left.\mathrm{CDCl}_{3}\right) \delta$ 7.77-7.75 (m, 2H), 7.45-7.37 (m, 3H), 5.23 (qq, $J=$ 6.3, $6.3 \mathrm{~Hz}, 1 \mathrm{H}), 1.37(\mathrm{~d}, J=6.3 \mathrm{~Hz}, 6 \mathrm{H}), 0.25(\mathrm{~s}, 9 \mathrm{H}) ;{ }^{13} \mathrm{C} \mathrm{NMR}\left(125 \mathrm{MHz} \mathrm{CDCl}_{3}\right) \delta 166.1,164.9,136.5$, 131.3, 128.3, 127.6, 69.6, 21.8, -0.2; IR (neat) 3062, 2981, 2900, 1727, 1667, 1387, 1375, 1275, 1248, 1200, $788 \mathrm{~cm}^{-1}$; HRMS (EI): Calcd for $\mathrm{C}_{10} \mathrm{H}_{14} \mathrm{NSi}\left(\mathrm{M}-\mathrm{C}_{4} \mathrm{H}_{7} \mathrm{O}_{2}\right)^{+} 176.0896$, found 176.0896 .

\section{Synthesis of tert-butyl (Z)-2-phenyl-2-[(trimethylsilyl)imino]acetate (1d)}

Under an argon atmosphere, a solution of ketoester $\mathbf{D}(103 \mathrm{mg}, 0.50 \mathrm{mmol})$ in toluene $(2.5 \mathrm{~mL})$ was stirred at $0{ }^{\circ} \mathrm{C}$ for $5 \mathrm{~min}$, and to it was added LHMDS in THF ( $0.39 \mathrm{~mL}, 0.51 \mathrm{mmol}, 1.30 \mathrm{~N}, 1.01$ equiv) slowly. After the mixture was stirred for $3 \mathrm{~h}$ at $0{ }^{\circ} \mathrm{C}$, the reaction was quenched with $\mathrm{H}_{2} \mathrm{O}(5.0 \mathrm{~mL})$, 
and the whole mixture was washed with $\mathrm{H}_{2} \mathrm{O}(5.0 \mathrm{~mL} \times 3)$, dried over anhydrous $\mathrm{Na}_{2} \mathrm{SO}_{4}$, and concentrated in vacuo to give the title compound $\mathbf{1} \mathbf{d}(121 \mathrm{mg})$.

tert-Butyl (Z)-2-phenyl-2-[(trimethylsilyl)imino]acetate (1d) ${ }^{7}$<smiles>CC(C)(C)OC(=O)/C(=N\[Si](C)(C)C)c1ccccc1</smiles>

Yield 87\%; Yellow oil; ${ }^{1} \mathrm{H}$ NMR (400 MHz, $\left.\mathrm{CDCl}_{3}\right) \delta$ 7.78-7.76 (m, 2H), 7.46-7.38 (m, 3H), $1.60(\mathrm{~s}, 9 \mathrm{H})$, 0.27 (s, 9H); ${ }^{13} \mathrm{C}$ NMR $\left(125 \mathrm{MHz}, \mathrm{CDCl}_{3}\right) \delta 165.7,165.0,136.9,131.0,128.2,127.7,83.3,28.3,0.2$; IR (neat) 3062, 2979, 1724, 1669, 1394, 1369, 1248, 1209, 1151, 843, $690 \mathrm{~cm}^{-1}$; HRMS (EI): Calcd for $\mathrm{C}_{15} \mathrm{H}_{23} \mathrm{NO}_{2} \mathrm{Si}(\mathrm{M})^{+}$277.1498, found 277.1491.

\section{Synthesis of cyclohexyl (Z)-2-phenyl-2-[(trimethylsilyl)imino]acetate (1e)}

Under an argon atmosphere, a solution of ketoester $\mathbf{E}(403 \mathrm{mg}, 1.73 \mathrm{mmol})$ in toluene $(8.7 \mathrm{~mL})$ was stirred at $0^{\circ} \mathrm{C}$ for $5 \mathrm{~min}$, and to it was added LHMDS in THF (1.3 mL, $1.75 \mathrm{mmol}, 1.30 \mathrm{~N}, 1.01$ equiv) slowly. After the mixture was stirred for $1 \mathrm{~h}$ at $0{ }^{\circ} \mathrm{C}$, the reaction was quenched with $\mathrm{H}_{2} \mathrm{O}(5.0 \mathrm{~mL})$, and the whole mixture was washed with $\mathrm{H}_{2} \mathrm{O}(5.0 \mathrm{~mL} \times 3)$, dried over anhydrous $\mathrm{Na}_{2} \mathrm{SO}_{4}$, and concentrated in vacuo to give the title compound $1 \mathrm{e}(435 \mathrm{mg})$.

Cyclohexyl (Z)-2-phenyl-2-[(trimethylsilyl)imino]acetate (1e)<smiles>C[Si](C)(C)/N=C(\C(=O)OC1CCCCC1)c1ccccc1</smiles>

Yield 83\%; Yellow oil; ${ }^{1} \mathrm{H}$ NMR $\left(500 \mathrm{MHz}, \mathrm{CDCl}_{3}\right)$ $\delta$ 7.77-7.75 (m, 2H), 7.47-7.38 (m, 3H), 5.03-4.98 (m, $1 \mathrm{H})$, $2.03-2.00(\mathrm{~m}, 2 \mathrm{H}), 1.79-1.75(\mathrm{~m}, 2 \mathrm{H}), 1.59-1.52(\mathrm{~m}, 3 \mathrm{H}), 1.46-1.38(\mathrm{~m}, 2 \mathrm{H}), 1.31-1.23(\mathrm{~m}, 1 \mathrm{H})$, 0.25 (s, 9H); ${ }^{13} \mathrm{C}$ NMR $\left(125 \mathrm{MHz} \mathrm{CDCl}_{3}\right) \delta 166.1,165.0,136.5,131.3,128.3,127.6,74.5,31.6,25.2$, 23.8, -0.2; IR (neat) 2940, 2861, 1725, 1665, 1449, 1260, 1194, 991, 847, 754, $695 \mathrm{~cm}^{-1}$; HRMS (EI): Calcd for $\mathrm{C}_{17} \mathrm{H}_{25} \mathrm{NO}_{2} \mathrm{Si}(\mathrm{M})^{+}$303.1655, found 303.1656.

\section{Synthesis of tert-butyl (Z)-2-(p-tolyl)-2-[(trimethylsilyl)imino]acetate (1f)}

Under an argon atmosphere, a solution of ketoester $\mathbf{F}(300 \mathrm{mg}, 1.36 \mathrm{mmol})$ in toluene $(6.8 \mathrm{~mL})$ was stirred at $0{ }^{\circ} \mathrm{C}$ for $5 \mathrm{~min}$, and to it was added LHMDS in THF (1.1 mL, $1.38 \mathrm{mmol}, 1.30 \mathrm{~N}, 1.01$ equiv) slowly. After the mixture was stirred for $3 \mathrm{~h}$ at $0{ }^{\circ} \mathrm{C}$, the reaction was quenched with $\mathrm{H}_{2} \mathrm{O}(5.0 \mathrm{~mL})$, and the whole mixture was washed with $\mathrm{H}_{2} \mathrm{O}(5.0 \mathrm{~mL} \times 3)$, dried over anhydrous $\mathrm{Na}_{2} \mathrm{SO}_{4}$, and concentrated in vacuo to give the title compound $\mathbf{1 f}(356 \mathrm{mg})$.

tert-Butyl (Z)-2-(p-tolyl)-2-[(trimethylsilyl)imino]acetate (1f) 


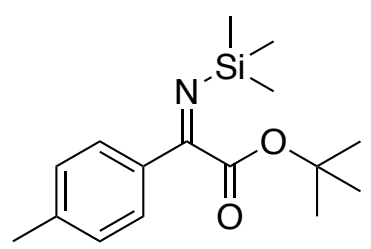

Yield 85\%; Yellow oil; ${ }^{1} \mathrm{H}$ NMR $\left(500 \mathrm{MHz}, \mathrm{CDCl}_{3}\right) \delta 7.67(\mathrm{~d}, J=7.9 \mathrm{~Hz}, 2 \mathrm{H}), 7.19(\mathrm{~d}, J=7.9 \mathrm{~Hz}, 2 \mathrm{H}), 2.37$ (s, 3H), 1.59 (s, 9H), 0.26 (s, 9H); ${ }^{13} \mathrm{C} \mathrm{NMR} \mathrm{(125} \mathrm{MHz,} \mathrm{CDCl} 3$ ) $\delta 165.9,164.9,141.4,134.4,128.9,127.7$, 83.1, 28.2, 21.4, 0.2; IR (neat) 2978, 1724, 1664, 1607, 1456, 1369, 1249, 1153, 967, 876, $842 \mathrm{~cm}^{-1}$; HRMS (EI): Calcd for $\mathrm{C}_{16} \mathrm{H}_{25} \mathrm{NO}_{2} \mathrm{Si}(\mathrm{M})^{+} 291.1655$, found 291.1661 .

\section{Synthesis of tert-butyl (Z)-2-(m-tolyl)-2-[(trimethylsilyl)imino]acetate (1g)}

Under an argon atmosphere, a solution of ketoester $\mathbf{G}(330 \mathrm{mg}, 1.50 \mathrm{mmol})$ in toluene $(7.5 \mathrm{~mL})$ was stirred at $0{ }^{\circ} \mathrm{C}$ for $5 \mathrm{~min}$, and to it was added LHMDS in THF (1.2 mL, $1.52 \mathrm{mmol}, 1.30 \mathrm{~N}, 1.01$ equiv) slowly. After the mixture was stirred for $1 \mathrm{~h}$ at $0{ }^{\circ} \mathrm{C}$, the reaction was quenched with $\mathrm{H}_{2} \mathrm{O}(5.0 \mathrm{~mL})$, and the whole mixture was washed with $\mathrm{H}_{2} \mathrm{O}(5.0 \mathrm{~mL} \times 3)$, dried over anhydrous $\mathrm{Na}_{2} \mathrm{SO}_{4}$, and concentrated in vacuo to give the title compound $1 \mathrm{~g}(434 \mathrm{mg})$.

tert-Butyl (Z)-2-(m-tolyl)-2-[(trimethylsilyl)imino]acetate (1g)<smiles>Cc1cccc(C(=N[Si](C)(C)C)C(=O)OC(C)(C)C)c1</smiles>

Yield 99\%; Yellow oil; ${ }^{1} \mathrm{H}$ NMR $\left(500 \mathrm{MHz}, \mathrm{CDCl}_{3}\right) \delta$ 7.63-7.59 $(\mathrm{m}, 1 \mathrm{H}), 7.56-7.51(\mathrm{~m}, 1 \mathrm{H})$, 7.30-7.24 (m, $2 \mathrm{H}), 2.38(\mathrm{~s}, 3 \mathrm{H}), 1.60(\mathrm{~s}, 9 \mathrm{H}), 0.27(\mathrm{~s}, 9 \mathrm{H}) ;{ }^{13} \mathrm{C} \mathrm{NMR}\left(125 \mathrm{MHz}, \mathrm{CDCl}_{3}\right) \delta 165.9,165.4,138.0,136.9$, $131.8,128.1,128.1,125.0,83.3,28.3,21.4,0.2$; IR (neat) 2970, 1723, 1665, 1370, 1244, 1146, 1023, 847, 751, 691, $575 \mathrm{~cm}^{-1}$; HRMS (EI): Calcd for $\mathrm{C}_{13} \mathrm{H}_{16} \mathrm{NO}_{2}\left(\mathrm{M}-\mathrm{C}_{3} \mathrm{H}_{9} \mathrm{Si}\right)^{+} 218.1181$, found 218.1171 .

\section{Synthesis of tert-butyl (Z)-2-(o-tolyl)-2-[(trimethylsilyl)imino]acetate (1h)}

Under an argon atmosphere, a solution of ketoester $\mathbf{H}(441 \mathrm{mg}, 2.00 \mathrm{mmol})$ in toluene $(10 \mathrm{~mL})$ was stirred at $0^{\circ} \mathrm{C}$ for $5 \mathrm{~min}$, and to it was added LHMDS in THF (1.6 mL, $2.02 \mathrm{mmol}, 1.30 \mathrm{~N}, 1.01$ equiv) slowly. After the mixture was stirred for $3.5 \mathrm{~h}$ at $0{ }^{\circ} \mathrm{C}$, the reaction was quenched with $\mathrm{H}_{2} \mathrm{O}(5.0 \mathrm{~mL})$, and the whole mixture was washed with $\mathrm{H}_{2} \mathrm{O}(5.0 \mathrm{~mL} \times 3)$, dried over anhydrous $\mathrm{Na}_{2} \mathrm{SO}_{4}$, and concentrated in vacuo to give the title compound $\mathbf{1 h}(536 \mathrm{mg})$.

tert-Butyl (Z)-2-(o-tolyl)-2-[(trimethylsilyl)imino]acetate (1h)<smiles>Cc1ccccc1/C(=N/[Si](C)(C)C)C(=O)OC(C)(C)C</smiles>

Yield 92\%; Yellow oil; ${ }^{1} \mathrm{H}$ NMR (500 MHz, $\left.\mathrm{CDCl}_{3}\right)$ $\delta$ 7.26-7.15 (m, 4H), $2.33(\mathrm{~s}, 3 \mathrm{H}), 1.48(\mathrm{~s}, 9 \mathrm{H}), 0.16$ (s, 
9H); ${ }^{13} \mathrm{C}$ NMR $\left(125 \mathrm{MHz}, \mathrm{CDCl}_{3}\right) \delta 168.4,163.8,139.4,135.5,130.5,128.9,127.7,125.3,82.5,27.9$, 19.9, 0.0; IR (neat) 2976, 1724, 1675, 1456, 1369, 1251, 1156, 976, 876, 843, 749, $598 \mathrm{~cm}^{-1}$; HRMS (EI): Calcd for $\mathrm{C}_{16} \mathrm{H}_{25} \mathrm{NO}_{2} \mathrm{Si}(\mathrm{M})^{+} 291.1655$, found 291.1659 .

\section{Synthesis of tert-butyl (Z)-2-(4-methoxyphenyl)-2-[(trimethylsilyl)imino]acetate (1i)}

Under an argon atmosphere, a solution of ketoester I (200 mg, $0.85 \mathrm{mmol})$ in toluene $(8.5 \mathrm{~mL})$ was stirred at $0{ }^{\circ} \mathrm{C}$ for $5 \mathrm{~min}$, and to it was added LHMDS in THF ( $0.66 \mathrm{~mL}, 0.86 \mathrm{mmol}, 1.30 \mathrm{~N}, 1.01$ equiv) slowly. After the mixture was stirred for $2 \mathrm{~h}$ at $0{ }^{\circ} \mathrm{C}$, the reaction was quenched with $\mathrm{H}_{2} \mathrm{O}(5.0 \mathrm{~mL})$, and the whole mixture was washed with $\mathrm{H}_{2} \mathrm{O}(5.0 \mathrm{~mL} \times 3)$, dried over anhydrous $\mathrm{Na}_{2} \mathrm{SO}_{4}$, and concentrated in vacuo to give the title compound $1 \mathbf{i}(260 \mathrm{mg})$.

tert-Butyl (Z)-2-(4-methoxyphenyl)-2-[(trimethylsilyl)imino]acetate (1i)

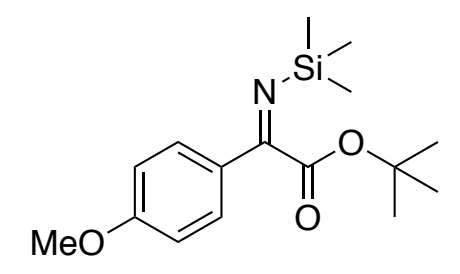

Yield 99\%; Yellow oil; ${ }^{1} \mathrm{H}$ NMR (500 MHz, $\left.\mathrm{CDCl}_{3}\right)$ 87.76-7.73 (m, 2H), 6.92-6.88 (m, 2H), $3.84(\mathrm{~s}, 3 \mathrm{H})$, 1.60 (s, 9H), 0.26 (s, 9H); ${ }^{13} \mathrm{C}$ NMR (125 MHz, CDCl$) \delta 166.0,164.3,162.0,130.0,129.5,113.6,83.2$, 55.4, 28.3, 0.27; IR (neat) 2977, 1724, 1661, 1602, 1574, 1513, 1254, 1152, 843, $793 \mathrm{~cm}^{-1}$; HRMS(EI): Calcd for $\mathrm{C}_{16} \mathrm{H}_{25} \mathrm{NO}_{3} \mathrm{Si}(\mathrm{M})^{+} 307.1604$, found 307.1608 .

\section{Synthesis of tert-butyl (Z)-2-(4-chlorophenyl)-2-[(trimethylsilyl)imino]acetate (1j)}

Under an argon atmosphere, a solution of ketoester $\mathbf{J}(218 \mathrm{mg}, 0.91 \mathrm{mmol})$ in toluene $(9.1 \mathrm{~mL})$ was stirred at $0{ }^{\circ} \mathrm{C}$ for $5 \mathrm{~min}$, and to it was added LHMDS in THF (0.78 mL, $0.91 \mathrm{mmol}, 1.30 \mathrm{~N}, 1.01$ equiv) slowly. After the mixture was stirred for $2 \mathrm{~h}$ at $0{ }^{\circ} \mathrm{C}$, the reaction was quenched with $\mathrm{H}_{2} \mathrm{O}(5.0 \mathrm{~mL})$, and the whole mixture was washed with $\mathrm{H}_{2} \mathrm{O}(5.0 \mathrm{~mL} \times 3)$, dried over anhydrous $\mathrm{Na}_{2} \mathrm{SO}_{4}$, and concentrated in vacuo to give the title compound $\mathbf{1} \mathbf{j}(282 \mathrm{mg})$.

tert-Butyl (Z)-2-(4-chlorophenyl)-2-[(trimethylsilyl)imino]acetate (1j)<smiles>CC(C)(C)OC(=O)C(=N[Si](C)(C)C)c1ccc(Cl)cc1</smiles>

Yield quant; Yellow oil; ${ }^{1} \mathrm{H}$ NMR (400 MHz, $\left.\mathrm{CDCl}_{3}\right) \delta$ 7.72-7.69 (m, 2H), 7.39-7.34 (m, 2H), $1.59(\mathrm{~s}, 9 \mathrm{H})$, 0.27 (s, 9H); $\left.{ }^{13} \mathrm{C} \mathrm{NMR} \mathrm{(100} \mathrm{MHz,} \mathrm{CDCl}\right) \delta 165.2,163.6,137.2,135.4,129.0,128.5,83.6,28.2,0.1$; IR (neat) 2979, 1726, 1670, 1592, 1488, 1369, 1249, 1153, 1091, $757 \mathrm{~cm}^{-1}$; HRMS (El): Calcd for $\mathrm{C}_{15} \mathrm{H}_{22} \mathrm{ClNO}_{2} \mathrm{Si}(\mathrm{M})^{+}$311.1108, found 311.1124. 


\section{Synthesis of tert-butyl (Z)-2-(4-bromophenyl)-2-[(trimethylsilyl)imino]acetate (1k)}

Under an argon atmosphere, a solution of ketoester $\mathbf{K}(855 \mathrm{mg}, 3.00 \mathrm{mmol})$ in toluene $(15 \mathrm{~mL})$ was stirred at $0^{\circ} \mathrm{C}$ for $5 \mathrm{~min}$, and to it was added LHMDS in THF (2.3 mL, $3.03 \mathrm{mmol}, 1.30 \mathrm{~N}, 1.01$ equiv) slowly. After the mixture was stirred for $2.5 \mathrm{~h}$ at $0{ }^{\circ} \mathrm{C}$, the reaction was quenched with $\mathrm{H}_{2} \mathrm{O}(5.0 \mathrm{~mL})$, and the whole mixture was washed with $\mathrm{H}_{2} \mathrm{O}(5.0 \mathrm{~mL} \times 3)$, dried over anhydrous $\mathrm{Na}_{2} \mathrm{SO}_{4}$, and concentrated in vacuo to give the title compound $\mathbf{1 k}(1.2 \mathrm{~g})$.

tert-Butyl (Z)-2-(4-bromophenyl)-2-[(trimethylsilyl)imino]acetate (1k)<smiles>CC(C)(C)OC(=O)/C(=N\[Si](C)(C)C)c1ccc(Br)cc1</smiles>

Yield quant; Yellow oil; ${ }^{1} \mathrm{H}$ NMR $\left(500 \mathrm{MHz}, \mathrm{CDCl}_{3}\right) \delta$ 7.65-7.63 (m, 2H), 7.54-7.51 (m, 2H), $1.59(\mathrm{~s}, 9 \mathrm{H})$, 0.27 (s, 9H); ${ }^{13} \mathrm{C} \mathrm{NMR}\left(125 \mathrm{MHz}, \mathrm{CDCl}_{3}\right) \delta$ 165.1, 163.7, 135.8, 131.4, 129.2, 125.8, 83.6, 28.2, 0.1; IR (neat) 2973, 2898, 1726, 1674, 1584, 1247, 1150, 984, 875, 845, 786, $753 \mathrm{~cm}^{-1}$; HRMS (EI): Calcd for $\mathrm{C}_{15} \mathrm{H}_{22} \mathrm{BrNO}_{2} \mathrm{Si}(\mathrm{M})^{+} 355.0603$, found 355.0602 .

\section{Synthesis of tert-butyl (Z)-2-(3-bromophenyl)-2-[(trimethylsilyl)imino]acetate (1)}

Under an argon atmosphere, a solution of ketoester $\mathbf{L}(504 \mathrm{mg}, 1.77 \mathrm{mmol})$ in toluene $(8.9 \mathrm{~mL})$ was stirred at $0^{\circ} \mathrm{C}$ for $5 \mathrm{~min}$, and to it was added LHMDS in THF (1.4 mL, $1.79 \mathrm{mmol}, 1.30 \mathrm{~N}, 1.01$ equiv) slowly. After the mixture was stirred for $1.5 \mathrm{~h}$ at $0{ }^{\circ} \mathrm{C}$, the reaction was quenched with $\mathrm{H}_{2} \mathrm{O}(5.0 \mathrm{~mL})$, and the whole mixture was washed with $\mathrm{H}_{2} \mathrm{O}(5.0 \mathrm{~mL} \times 3)$, dried over anhydrous $\mathrm{Na}_{2} \mathrm{SO}_{4}$, and concentrated in vacuo to give the title compound $\mathbf{1}$ ( $610 \mathrm{mg}$ ).

tert-Butyl (Z)-2-(3-bromophenyl)-2-[(trimethylsilyl)imino]acetate (1I)<smiles>CC(C)(C)OC(=O)/C(=N\[Si](C)(C)C)c1cccc(Br)c1</smiles>

Yield 97\%; Yellow oil; ${ }^{1} \mathrm{H}$ NMR $\left(500 \mathrm{MHz}, \mathrm{CDCl}_{3}\right) \delta$ 7.95-7.94 (m, $\left.1 \mathrm{H}\right), 7.65-7.63(\mathrm{~m}, 1 \mathrm{H})$, 7.57-7.55 (m, $1 \mathrm{H}), 7.29-7.25(\mathrm{~m}, 1 \mathrm{H}), 1.60(\mathrm{~s}, 9 \mathrm{H}), 0.27(\mathrm{~s}, 9 \mathrm{H}) ;{ }^{13} \mathrm{C} \mathrm{NMR}\left(125 \mathrm{MHz}, \mathrm{CDCl}_{3}\right) \delta$ 165.0, 163.2, 138.9, 133.8, 130.6, 129.7, 126.4, 122.6, 83.8, 28.2, 0.1; IR (neat) 2972, 1724, 1670, 1565, 1465, 1370, 1252, 1195, 1151, 992, 844, 792, 689, $518 \mathrm{~cm}^{-1}$; HRMS (EI): Calcd for $\mathrm{C}_{15} \mathrm{H}_{22} \mathrm{BrNO}_{2} \mathrm{Si}(\mathrm{M})^{+} 355.0603$, found 355.0613.

\section{Synthesis of tert-butyl (Z)-2-(2-chlorophenyl)-2-[(trimethylsilyl)imino]acetate (1m)}

Under an argon atmosphere, a solution of ketoester $\mathbf{M}(481 \mathrm{mg}, 2.00 \mathrm{mmol})$ in toluene $(10 \mathrm{~mL})$ was stirred at $0^{\circ} \mathrm{C}$ for $5 \mathrm{~min}$, and to it was added LHMDS in THF (1.6 mL, $2.02 \mathrm{mmol}, 1.30 \mathrm{~N}, 1.01$ equiv) 
slowly. After the mixture was stirred for $3.5 \mathrm{~h}$ at $0{ }^{\circ} \mathrm{C}$, the reaction was quenched with $\mathrm{H}_{2} \mathrm{O}(5.0 \mathrm{~mL})$, and the whole mixture was washed with $\mathrm{H}_{2} \mathrm{O}(5.0 \mathrm{~mL} \times 3)$, dried over anhydrous $\mathrm{Na}_{2} \mathrm{SO}_{4}$, and concentrated in vacuo to give the title compound $1 \mathrm{~m}$ (572 mg).

tert-Butyl (Z)-2-(2-chlorophenyl)-2-[(trimethylsilyl)imino]acetate (1m)<smiles>CC(C)(C)OC(=O)/C(=N\[Si](C)(C)C)c1ccccc1Cl</smiles>

Yield 92\%; Yellow oil; ${ }^{1} \mathrm{H}$ NMR (500 MHz, $\left.\mathrm{CDCl}_{3}\right) \delta$ 7.33-7.25 (m, 4H), $1.46(\mathrm{~s}, 9 \mathrm{H}), 0.18(\mathrm{~s}, 9 \mathrm{H}) ;{ }^{13} \mathrm{C} \mathrm{NMR}$ (125 MHz, $\mathrm{CDCl}_{3}$ ) $\delta 165.1,161.5,139.7,131.4,130.1,129.7,129.1,126.6,82.7,27.7,0.1$; IR (neat) 2974, 2898, 1730, 1682, 1369, 1251, 1158, 1062, 981, 845 754, $693 \mathrm{~cm}^{-1}$; HRMS (El): Calcd for $\mathrm{C}_{11} \mathrm{H}_{13} \mathrm{CINOSi}\left(\mathrm{M}-\mathrm{C}_{4} \mathrm{H}_{9} \mathrm{O}\right)^{+} 238.0455$, found 238.0447 .

\section{Synthesis of tert-Butyl (Z)-2-(4-cyanophenyl)-2-[(trimethylsilyl)imino]acetate (1n)}

Under an argon atmosphere, a solution of ketoester $\mathbf{N}(33.9 \mathrm{mg}, 0.15 \mathrm{mmol})$ in toluene $(0.75 \mathrm{~mL})$ was stirred at $0{ }^{\circ} \mathrm{C}$ for $5 \mathrm{~min}$, and to it was added LHMDS in THF (0.11 mL, $0.15 \mathrm{mmol}, 1.30 \mathrm{~N}, 1.01$ equiv) slowly. After the mixture was stirred for $5 \mathrm{~h}$ at $0{ }^{\circ} \mathrm{C}$, the reaction was quenched with $\mathrm{H}_{2} \mathrm{O}(5.0$ $\mathrm{mL})$, and the whole mixture was washed with $\mathrm{H}_{2} \mathrm{O}(5.0 \mathrm{~mL} \times 3)$, dried over anhydrous $\mathrm{Na}_{2} \mathrm{SO}_{4}$, and concentrated in vacuo to give the title compound $1 \mathrm{n}(31.1 \mathrm{mg})$.

tert-Butyl (Z)-2-(4-cyanophenyl)-2-[(trimethylsilyl)imino]acetate (1n)<smiles>CC(C)(C)OC(=O)/C(=N\[Si](C)(C)C)c1ccc(C#N)cc1</smiles>

Yield 69\%; Yellow oil; ${ }^{1} \mathrm{H}$ NMR $\left(500 \mathrm{MHz}, \mathrm{CDCl}_{3}\right) \delta$ 7.87-7.85 (m, 2H), 7.70-7.69 (m, 2H), $1.60(\mathrm{~s}, 9 \mathrm{H})$, 0.28 (s, 9H); ${ }^{13} \mathrm{C} \mathrm{NMR}\left(125 \mathrm{MHz}, \mathrm{CDCl}_{3}\right) \delta 164.5,162.8,140.4,132.1,128.2,118.5,114.2,84.1,28.2$, -0.0; IR (neat) 2980, 2917, 2848, 2230, 1726, 1610, 1370, 1250, 1153, 967, 787, $767 \mathrm{~cm}^{-1}$; HRMS (EI): Calcd for $\mathrm{C}_{16} \mathrm{H}_{22} \mathrm{~N}_{2} \mathrm{O}_{2} \mathrm{Si}(\mathrm{M})^{+} 302.1451$, found 302.1462 .

\section{Synthesis of tert-butyl (E)-2-(thiophen-2-yl)-2-[(trimethylsilyl)imino]acetate (10)}

Under an argon atmosphere, a solution of ketoester $\mathbf{O}(623 \mathrm{mg}, 2.94 \mathrm{mmol})$ in toluene $(29 \mathrm{~mL})$ was stirred at $0{ }^{\circ} \mathrm{C}$ for $5 \mathrm{~min}$, and to it was added LHMDS in THF (2.3 mL, $2.96 \mathrm{mmol}, 1.30 \mathrm{~N}, 1.01$ equiv) slowly. After the mixture was stirred for $2 \mathrm{~h}$ at $0{ }^{\circ} \mathrm{C}$, the reaction was quenched with $\mathrm{H}_{2} \mathrm{O}(5.0 \mathrm{~mL})$, and the whole mixture was washed with $\mathrm{H}_{2} \mathrm{O}(5.0 \mathrm{~mL} \times 3)$, dried over anhydrous $\mathrm{Na}_{2} \mathrm{SO}_{4}$, and concentrated in vacuo to give the title compound 10 (768 $\mathrm{mg})$. 
tert-Butyl (E)-2-(thiophen-2-yl)-2-[(trimethylsilyl)imino]acetate (10)<smiles>CC(C)(C)OC(=O)/C(=N\[Si](C)(C)C)c1cccs1</smiles>

Yield 92\%; Yellow oil; ${ }^{1} \mathrm{H}$ NMR $\left(500 \mathrm{MHz}, \mathrm{CDCl}_{3}\right) \delta$ 7.44-7.42 (m, 2H), 7.07-7.05 (m, 1H), $1.61(\mathrm{~s}, 9 \mathrm{H})$, 0.25 (s, 9H); $\left.{ }^{13} \mathrm{C} \mathrm{NMR} \mathrm{(125} \mathrm{MHz,} \mathrm{CDCl}\right) \delta 163.5,158.2,145.8,130.8,130.0,127.8,83.6,28.2,0.2 ;$ IR (neat) 2978, 1727, 1647, 1395, 1290, 1248, 1151, 944, 869, 841, 789, $714 \mathrm{~cm}^{-1}$; HRMS (EI): Calcd for $\mathrm{C}_{13} \mathrm{H}_{21} \mathrm{NO}_{2} \mathrm{SSi}(\mathrm{M})^{+} 283.1062$, found 283.1048 .

\section{Synthesis of tert-butyl (Z)-2-(furan-2-yl)-2-[(trimethylsilyl)imino]acetate (1p)}

Under an argon atmosphere, a solution of ketoester $\mathbf{P}(100 \mathrm{mg}, 0.51 \mathrm{mmol})$ in toluene $(5.1 \mathrm{~mL})$ was stirred at $0{ }^{\circ} \mathrm{C}$ for $5 \mathrm{~min}$, and to it was added LHMDS in THF ( $0.40 \mathrm{~mL}, 0.52 \mathrm{mmol}, 1.30 \mathrm{~N}, 1.01$ equiv) slowly. After the mixture was stirred for $2 \mathrm{~h}$ at $0{ }^{\circ} \mathrm{C}$, the reaction was quenched with $\mathrm{H}_{2} \mathrm{O}(5.0 \mathrm{~mL})$, and the whole mixture was washed with $\mathrm{H}_{2} \mathrm{O}(5.0 \mathrm{~mL} \times 3)$, dried over anhydrous $\mathrm{Na}_{2} \mathrm{SO}_{4}$, and concentrated in vacuo to give the title compound $1 \mathrm{p}(128 \mathrm{mg})$.

tert-Butyl (Z)-2-(furan-2-yl)-2-[(trimethylsilyl)imino]acetate (1p)

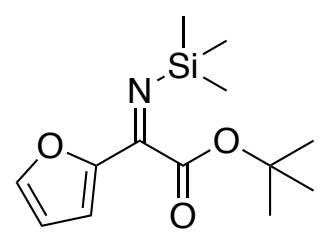

Yield 94\%; Yellow oil; ${ }^{1} \mathrm{H}$ NMR (500 MHz, $\left.\mathrm{CDCl}_{3}\right) \delta 7.55(\mathrm{~d}, J=1.7 \mathrm{~Hz}, 1 \mathrm{H}), 6,89(\mathrm{~d}, J=3.5 \mathrm{~Hz}, 1 \mathrm{H}), 6.48$ (dd, $J=1.7,3.5 \mathrm{~Hz}, 1 \mathrm{H}), 1.60(\mathrm{~s}, 9 \mathrm{H}), 0.29(\mathrm{~s}, 9 \mathrm{H}) ;{ }^{13} \mathrm{C} \mathrm{NMR}\left(125 \mathrm{MHz}, \mathrm{CDCl}_{3}\right) \delta 163.2,154.6,151.7$, $145.5,115.8,111.7,83.5,28.1,0.4$; IR (neat) 2978, 2902, 1731, 1657, 1394, 1380, 1370, 1244, 1150, 991, 922, 863, 843, $755 \mathrm{~cm}^{-1}$; HRMS (EI): Calcd for $\mathrm{C}_{10} \mathrm{H}_{12} \mathrm{NO}_{3}\left(\mathrm{M}-\mathrm{C}_{3} \mathrm{H}_{9} \mathrm{Si}\right)^{+}$194.0817, found 194.0816.

\section{Synthesis of ethyl (Z)-2-(4-chlorophenyl)-2-[(trimethylsilyl)imino]acetate (1q)}

Under an argon atmosphere, a solution of ketoester $\mathbf{Q}(638 \mathrm{mg}, 3.00 \mathrm{mmol})$ in toluene $(15 \mathrm{~mL})$ was stirred at $0^{\circ} \mathrm{C}$ for $5 \mathrm{~min}$, and to it was added LHMDS in THF (2.3 mL, $3.03 \mathrm{mmol}, 1.30 \mathrm{~N}, 1.01$ equiv) slowly. After the mixture was stirred for $2 \mathrm{~h}$ at $0{ }^{\circ} \mathrm{C}$, the reaction was quenched with $\mathrm{H}_{2} \mathrm{O}(5.0 \mathrm{~mL})$, and the whole mixture was washed with $\mathrm{H}_{2} \mathrm{O}(5.0 \mathrm{~mL} \times 3)$, dried over anhydrous $\mathrm{Na}_{2} \mathrm{SO}_{4}$, and concentrated in vacuo to give the title compound $\mathbf{1 q}(815 \mathrm{mg})$.

Ethyl (Z)-2-(4-chlorophenyl)-2-[(trimethylsilyl)imino]acetate (1q)<smiles>CCOC(=O)/C(=N\[Si](C)(C)C)c1ccc(Cl)cc1</smiles> 
Yield 96\%; Yellow oil; ${ }^{1} \mathrm{H}$ NMR (400 MHz, $\left.\mathrm{CDCl}_{3}\right) \delta$ 7.73-7.69 (m, 2H), 7.40-7.36 (m, 2H), 4.34 (q, J = 7.1 $\mathrm{Hz}, 2 \mathrm{H}), 1.38(\mathrm{t}, J=7.1 \mathrm{~Hz}, 3 \mathrm{H}), 0.24(\mathrm{~s}, 9 \mathrm{H}) ;{ }^{13} \mathrm{C} \mathrm{NMR}\left(100 \mathrm{MHz}, \mathrm{CDCl}_{3}\right) \delta 165.8,163.2,137.6,134.7$, 129.0, 128.6, 61.5, 14.1, -0.3; IR (neat) 2962, 1731, 1666, 1591, 1487, 1401, 1285, 1249, 1195, 1091, 1020, 978, 842, $757 \mathrm{~cm}^{-1}$; HRMS (EI): Calcd for $\mathrm{C}_{10} \mathrm{H}_{9} \mathrm{CINO}_{2}\left(\mathrm{M}-\mathrm{C}_{3} \mathrm{H}_{9} \mathrm{Si}\right)^{+} 210.0322$, found 210.0322 .

\section{Synthesis of ethyl (Z)-2-(4-methoxyphenyl)-2-[(trimethylsilyl)imino]acetate (1r)}

Under an argon atmosphere, a solution of ketoester $\mathbf{R}(416 \mathrm{mg}, 2.00 \mathrm{mmol})$ in toluene $(10 \mathrm{~mL})$ was stirred at $0^{\circ} \mathrm{C}$ for $5 \mathrm{~min}$, and to it was added LHMDS in THF (1.55 mL, $2.02 \mathrm{mmol}, 1.30 \mathrm{~N}, 1.01$ equiv) slowly. After the mixture was stirred for $4.5 \mathrm{~h}$ at $0{ }^{\circ} \mathrm{C}$, the reaction was quenched with $\mathrm{H}_{2} \mathrm{O}(5.0 \mathrm{~mL})$, and the whole mixture was washed with $\mathrm{H}_{2} \mathrm{O}(5.0 \mathrm{~mL} \times 3)$, dried over anhydrous $\mathrm{Na}_{2} \mathrm{SO}_{4}$, and concentrated in vacuo to give the title compound $1 \mathrm{r}(558 \mathrm{mg})$.

Ethyl (Z)-2-(4-methoxyphenyl)-2-[(trimethylsilyl)imino]acetate (1r)

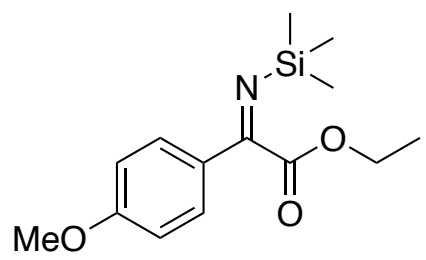

Yield quant; Yellow oil; ${ }^{1} \mathrm{H}$ NMR $\left(400 \mathrm{MHz}, \mathrm{CDCl}_{3}\right) \delta$ 7.75-7.71 $(\mathrm{m}, 2 \mathrm{H}), 6.92-6.88(\mathrm{~m}, 2 \mathrm{H}), 4.33(\mathrm{q}, J=$ $7.2 \mathrm{~Hz}, 2 \mathrm{H}), 3.83(\mathrm{~s}, 3 \mathrm{H}), 1.38(\mathrm{t}, J=7.2 \mathrm{~Hz}, 3 \mathrm{H}), 0.22(\mathrm{~s}, 9 \mathrm{H}) ;{ }^{13} \mathrm{C} \mathrm{NMR}\left(100 \mathrm{MHz}, \mathrm{CDCl}_{3}\right) \delta$ 166.5, 163.9, $162.3,129.5,129.3,113.7,61.2,55.4,14.1,-0.2$; IR (neat) 2961, 2899, 1729, 1659, 1602, 1510, 1254, 1200, 1164, 1025, 874, 840, $758 \mathrm{~cm}^{-1}$; HRMS (El): Calcd for $\mathrm{C}_{11} \mathrm{H}_{12} \mathrm{NO}_{3}\left(\mathrm{M}-\mathrm{C}_{3} \mathrm{H}_{9} \mathrm{Si}\right)^{+}$206.0817, found 206.0811.

\section{Synthesis of ethyl (Z)-2-(naphthalen-1-yl)-2-[(trimethylsilyl)imino]acetate (1s)}

Under an argon atmosphere, a solution of ketoester $\mathbf{S}(460 \mathrm{mg}, 2.00 \mathrm{mmol})$ in toluene $(10 \mathrm{~mL})$ was stirred at $0{ }^{\circ} \mathrm{C}$ for $5 \mathrm{~min}$, and to it was added LHMDS in THF (1.55 mL, $2.02 \mathrm{mmol}, 1.30 \mathrm{~N}, 1.01$ equiv) slowly. After the mixture was stirred for $2 \mathrm{~h}$ at $0{ }^{\circ} \mathrm{C}$, the reaction was quenched with $\mathrm{H}_{2} \mathrm{O}(5.0 \mathrm{~mL})$, and the whole mixture was washed with $\mathrm{H}_{2} \mathrm{O}(5.0 \mathrm{~mL} \times 3)$, dried over anhydrous $\mathrm{Na}_{2} \mathrm{SO}_{4}$, and concentrated in vacuo to give the title compound $1 \mathrm{~s}$ (486 $\mathrm{mg}$ ).

Ethyl (Z)-2-(naphthalen-1-yl)-2-[(trimethylsilyl)imino]acetate (1s)<smiles>CCOC(=O)/C(=N\[Si](C)(C)C)c1cccc2ccccc12</smiles>

Yield 81\%; Yellow oil; ${ }^{1} \mathrm{H}$ NMR $\left(400 \mathrm{MHz}, \mathrm{CDCl}_{3}\right)$ 8 8.18-8.15 (m, $\left.1 \mathrm{H}\right), 7.89-7.84(\mathrm{~m}, 2 \mathrm{H})$, 7.52-7.44 (m, $4 \mathrm{H}), 4.27(\mathrm{q}, J=7.1 \mathrm{~Hz}, 2 \mathrm{H}), 1.27(\mathrm{t}, J=7.1 \mathrm{~Hz}, 3 \mathrm{H}), 0.12(\mathrm{~s}, 9 \mathrm{H}) ;{ }^{13} \mathrm{C} \mathrm{NMR}\left(100 \mathrm{MHz}, \mathrm{CDCl}_{3}\right) \delta 167.2$, $165.0,136.3,133.6,130.6,130.1,128.4,126.9,126.2,126.2,125.1,124.7,61.7,14.0,-0.2$; IR (neat) 3056, 2958, 2899, 1728, 1666, 1508, 1248, 1221, 1088, 844, $780 \mathrm{~cm}^{-1}$; HRMS (EI): Calcd for $\mathrm{C}_{14} \mathrm{H}_{12} \mathrm{NO}_{2}$ 


\section{3. [Table 1] Examination of Solvents for $\mathbf{N}$-Alkylation of $\boldsymbol{N}$-Silyl $\alpha$-Iminoester}

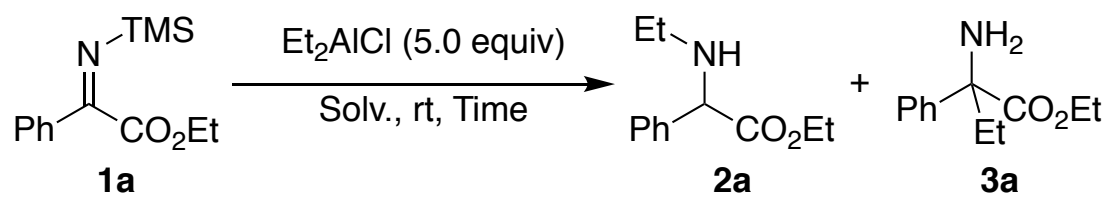

(Table 1, entry 1)

Under an argon atmosphere, a solution of $\mathrm{N}$-silyl $\alpha$-iminoester 1a (37.4 $\mathrm{mg}, 0.15 \mathrm{mmol}$ ) in EtCN $(0.50 \mathrm{~mL})$ was stirred at room temperature for $5 \mathrm{~min}$, and to it was added $\mathrm{Et}_{2} \mathrm{AlCl}$ in hexane $(0.70 \mathrm{~mL}$, $0.75 \mathrm{mmol}, 1.07 \mathrm{~N}, 5.0$ equiv) slowly. After the mixture was stirred for $2.5 \mathrm{~h}$, the reaction was quenched with a solution of Rochelle's salt in water (22 wt\%, $5.0 \mathrm{~mL}$ ), and the whole mixture was extracted with ethyl acetate $(10.0 \mathrm{~mL} \times 3)$. The combined extracts were washed with a solution of Rochelle's salt in water (22 wt\%, $15 \mathrm{~mL}$ ), dried over anhydrous $\mathrm{Na}_{2} \mathrm{SO}_{4}$, and concentrated in vacuo. The crude product was purified on silica gel TLC ( $n$-hexane/ethyl acetate $=5 / 1$ ) to give ethyl 2-(ethylamino)-2-phenylacetate 2 a (8,65 mg, 28\%) and 3a (5.35 mg, 17\%).

Ethyl 2-(ethylamino)-2-phenylacetate (2a)<smiles>CCNC(C(=O)OCC)c1ccccc1</smiles>

Yield 28\%; Yellow oil; ${ }^{1} \mathrm{H}$ NMR $\left(500 \mathrm{MHz}, \mathrm{CDCl}_{3}\right) \delta 7.39-7.26(\mathrm{~m}, 5 \mathrm{H}), 4.36(\mathrm{~s}, 1 \mathrm{H}), 4.20(\mathrm{dq}, J=7.2$, $11.0 \mathrm{~Hz}, 1 \mathrm{H}), 4.12(\mathrm{dq}, J=7.2,11.0 \mathrm{~Hz}, 1 \mathrm{H}), 2.64(\mathrm{dq}, J=7.1,11.1 \mathrm{~Hz}, 1 \mathrm{H}), 2.56(\mathrm{dq}, J=7.1,11.1 \mathrm{~Hz}$, 1H), 1.92 (brs, 1H), 1.21 (dd, $J=7.2,7.2 \mathrm{~Hz}, 3 \mathrm{H}), 1.13$ (dd, $J=7.1,7.1 \mathrm{~Hz}, 3 \mathrm{H}) ;{ }^{13} \mathrm{C} \mathrm{NMR}(100 \mathrm{MHz}$, $\left.\mathrm{CDCl}_{3}\right) \delta 173.0,138.2,128.6,128.0,127.3,65.4,61.1,42.0,15.1,14.1$; IR (neat) 3421, 2973, 2937, 1734, 1646, 1454, 1369, 1205, 1178, 1028, 730, $699 \mathrm{~cm}^{-1}$; HRMS(EI): Calcd for $\mathrm{C}_{9} \mathrm{H}_{12} \mathrm{~N}\left(\mathrm{M}-\mathrm{C}_{3} \mathrm{H}_{5} \mathrm{O}_{2}\right)^{+}$ 134.0970, found 134.0966 .

Ethyl 2-amino-2-phenylbutanoate (3a) ${ }^{9}$<smiles>CCOC(=O)C(N)(CC)c1ccccc1</smiles>

Yield 17\%; Yellow oil.

(Table 1, entry 2)

Under an argon atmosphere, a solution of $\mathrm{N}$-silyl $\alpha$-iminoester $1 \mathrm{a}(37.4 \mathrm{mg}, 0.15 \mathrm{mmol})$ in $\mathrm{MeCN}$ $(0.50 \mathrm{~mL})$ was stirred at room temperature for $5 \mathrm{~min}$, and to it was added $\mathrm{Et}_{2} \mathrm{AlCl}$ in hexane $(0.70 \mathrm{~mL}$, $0.75 \mathrm{mmol}, 1.07 \mathrm{~N}, 5.0$ equiv) slowly. After the mixture was stirred for $2.5 \mathrm{~h}$, the reaction was quenched with a solution of Rochelle's salt in water $(22 \mathrm{wt} \%, 5.0 \mathrm{~mL})$, and the whole mixture was 
extracted with ethyl acetate $(10.0 \mathrm{~mL} \times 3)$. The combined extracts were washed with a solution of Rochelle's salt in water (22 wt\%, $15 \mathrm{~mL}$ ), dried over anhydrous $\mathrm{Na}_{2} \mathrm{SO}_{4}$, and concentrated in vacuo. The crude product was purified on silica gel TLC ( $n$-hexane/ethyl acetate $=6 / 1$ ) to give ethyl 2-(ethylamino)-2-phenylacetate 2 a $(9.20 \mathrm{mg}, 30 \%)$ and $\mathbf{3 a}(6.80 \mathrm{mg}, 22 \%)$.

(Table 1, entry 3)

Under an argon atmosphere, a solution of $\mathrm{N}$-silyl $\alpha$-iminoester 1a $(37.4 \mathrm{mg}, 0.15 \mathrm{mmol})$ in DMSO $(0.50 \mathrm{~mL})$ was stirred at room temperature for $5 \mathrm{~min}$, and to it was added $\mathrm{Et}_{2} \mathrm{AlCl}$ in hexane $(0.70 \mathrm{~mL}$, $0.75 \mathrm{mmol}, 1.07 \mathrm{~N}, 5.0$ equiv) slowly. After the mixture was stirred for $3.5 \mathrm{~h}$, the reaction was quenched with a solution of Rochelle's salt in water $(22 \mathrm{wt} \%, 5.0 \mathrm{~mL})$, and the whole mixture was extracted with ethyl acetate $(10.0 \mathrm{~mL} \times 3)$. The combined extracts were washed with a solution of Rochelle's salt in water (22 wt\%, $15 \mathrm{~mL}$ ), dried over anhydrous $\mathrm{Na}_{2} \mathrm{SO}_{4}$, and concentrated in vacuo. The crude product was purified on silica gel TLC ( $n$-hexane/ethyl acetate $=5 / 1$ ) to give ethyl 2-(ethylamino)-2-phenylacetate 2 a (13.1 mg, 42\%) and 3a (0.92 mg, 3\%).

(Table 1, entry 4)

Under an argon atmosphere, a solution of $N$-silyl $\alpha$-iminoester $1 \mathrm{a}(37.4 \mathrm{mg}, 0.15 \mathrm{mmol})$ in DMF $(0.50 \mathrm{~mL})$ was stirred at room temperature for $5 \mathrm{~min}$, and to it was added $\mathrm{Et}_{2} \mathrm{AlCl}$ in hexane $(0.70 \mathrm{~mL}$, $0.75 \mathrm{mmol}, 1.07 \mathrm{~N}, 5.0$ equiv) slowly. After the mixture was stirred for $14 \mathrm{~h}$, the reaction was quenched with a solution of Rochelle's salt in water $(22 \mathrm{wt} \%, 5.0 \mathrm{~mL}$ ), and the whole mixture was extracted with ethyl acetate $(10.0 \mathrm{~mL} \times 3)$. The combined extracts were washed with a solution of Rochelle's salt in water $(22 \mathrm{wt} \%, 15 \mathrm{~mL})$, dried over anhydrous $\mathrm{Na}_{2} \mathrm{SO}_{4}$, and concentrated in vacuo. The crude product was purified on silica gel TLC ( $n$-hexane/ethyl acetate $=5 / 1$ ) to give ethyl 2-(ethylamino)-2-phenylacetate 2 a (18.4 mg, 59\%).

(Table 1, entry 5)

Under an argon atmosphere, a solution of $N$-silyl $\alpha$-iminoester 1 a $(37.4 \mathrm{mg}, 0.15 \mathrm{mmol})$ in toluene $(0.50 \mathrm{~mL})$ was stirred at room temperature for $5 \mathrm{~min}$, and to it was added $\mathrm{Et}_{2} \mathrm{AlCl}$ in hexane $(0.70 \mathrm{~mL}$, $0.75 \mathrm{mmol}, 1.07 \mathrm{~N}, 5.0$ equiv) slowly. After the mixture was stirred for $9 \mathrm{~h}$, the reaction was quenched with a solution of Rochelle's salt in water $(22 \mathrm{wt} \%, 5.0 \mathrm{~mL})$, and the whole mixture was extracted with ethyl acetate $(10.0 \mathrm{~mL} \times 3)$. The combined extracts were washed with a solution of Rochelle's salt in water $\left(22 \mathrm{wt} \%, 15 \mathrm{~mL}\right.$ ), dried over anhydrous $\mathrm{Na}_{2} \mathrm{SO}_{4}$, and concentrated in vacuo. The crude product was purified on silica gel TLC ( $n$-hexane/ethyl acetate $=5 / 1$ ) to give ethyl 2-(ethylamino)-2-phenylacetate 2 a $(2.27 \mathrm{mg}, 7 \%)$.

(Table 1, entry 6)

Under an argon atmosphere, a solution of $N$-silyl $\alpha$-iminoester 1 a $(37.4 \mathrm{mg}, 0.15 \mathrm{mmol})$ in hexane $(0.50 \mathrm{~mL})$ was stirred at room temperature for $5 \mathrm{~min}$, and to it was added $\mathrm{Et}_{2} \mathrm{AlCl}$ in hexane $(0.70 \mathrm{~mL}$, $0.75 \mathrm{mmol}, 1.07 \mathrm{~N}, 5.0$ equiv) slowly. After the mixture was stirred for $3 \mathrm{~h}$, the reaction was quenched with a solution of Rochelle's salt in water $(22 \mathrm{wt} \%, 5.0 \mathrm{~mL}$ ), and the whole mixture was extracted with ethyl acetate $(10.0 \mathrm{~mL} \times 3)$. The combined extracts were washed with a solution of Rochelle's salt in water (22 wt\%, $15 \mathrm{~mL}$ ), dried over anhydrous $\mathrm{Na}_{2} \mathrm{SO}_{4}$, and concentrated in vacuo. The crude product was purified on silica gel TLC ( $n$-hexane/ethyl acetate $=5 / 1$ ) to give ethyl 2-(ethylamino)-2-phenylacetate 2 a (2.54 mg, 8\%) and 3a (10.8 mg, 35\%). 
(Table 1, entry 7)

Under an argon atmosphere, a solution of $N$-silyl $\alpha$-iminoester 1 a (37.4 mg, $0.15 \mathrm{mmol}$ ) in $\mathrm{CH}_{2} \mathrm{Cl}_{2}$ $(0.50 \mathrm{~mL})$ was stirred at room temperature for $5 \mathrm{~min}$, and to it was added $\mathrm{Et}_{2} \mathrm{AlCl}$ in hexane $(0.70 \mathrm{~mL}$, $0.75 \mathrm{mmol}, 1.07 \mathrm{~N}, 5.0$ equiv) slowly. After the mixture was stirred for $3.5 \mathrm{~h}$, the reaction was quenched with a solution of Rochelle's salt in water (22 wt\%, $5.0 \mathrm{~mL}$ ), and the whole mixture was extracted with ethyl acetate $(10.0 \mathrm{~mL} \times 3)$. The combined extracts were washed with a solution of Rochelle's salt in water (22 wt\%, $15 \mathrm{~mL}$ ), dried over anhydrous $\mathrm{Na}_{2} \mathrm{SO}_{4}$, and concentrated in vacuo. The crude product was purified on silica gel TLC ( $n$-hexane/ethyl acetate $=5 / 1$ ) to give ethyl 2-(ethylamino)-2-phenylacetate $\mathbf{2 a}(0.89 \mathrm{mg}, 3 \%)$ and 3 a (9.00 mg, 29\%).

(Table 1, entry 8)

Under an argon atmosphere, a solution of $N$-silyl $\alpha$-iminoester 1 a $(37.4 \mathrm{mg}, 0.15 \mathrm{mmol})$ in $\mathrm{C}_{2} \mathrm{H}_{4} \mathrm{Cl}_{2}$ $(0.50 \mathrm{~mL})$ was stirred at room temperature for $5 \mathrm{~min}$, and to it was added $\mathrm{Et}_{2} \mathrm{AlCl}$ in hexane $(0.70 \mathrm{~mL}$, $0.75 \mathrm{mmol}, 1.07 \mathrm{~N}, 5.0$ equiv) slowly. After the mixture was stirred for $3 \mathrm{~h}$, the reaction was quenched with a solution of Rochelle's salt in water (22 wt\%, $5.0 \mathrm{~mL}$ ), and the whole mixture was extracted with ethyl acetate $(10.0 \mathrm{~mL} \times 3)$. The combined extracts were washed with a solution of Rochelle's salt in water $\left(22 \mathrm{wt} \%, 15 \mathrm{~mL}\right.$ ), dried over anhydrous $\mathrm{Na}_{2} \mathrm{SO}_{4}$, and concentrated in vacuo. The crude product was purified on silica gel TLC ( $n$-hexane/ethyl acetate $=5 / 1$ ) to give ethyl 2-amino-2-phenylbutanoate 3a (5.12 mg, 17\%).

(Table 1, entry 9)

Under an argon atmosphere, a solution of $N$-silyl $\alpha$-iminoester $1 \mathrm{a}$ ( $37.4 \mathrm{mg}, 0.15 \mathrm{mmol}$ ) in $\mathrm{Et}_{2} \mathrm{O}(0.50$ $\mathrm{mL}$ ) was stirred at room temperature for $5 \mathrm{~min}$, and to it was added $\mathrm{Et}_{2} \mathrm{AICl}$ in hexane $(0.70 \mathrm{~mL}, 0.75$ mmol, $1.07 \mathrm{~N}, 5.0$ equiv) slowly. After the mixture was stirred for $3 \mathrm{~h}$, the reaction was quenched with a solution of Rochelle's salt in water $(22 \mathrm{wt} \%, 5.0 \mathrm{~mL})$, and the whole mixture was extracted with ethyl acetate $(10.0 \mathrm{~mL} \times 3)$. The combined extracts were washed with a solution of Rochelle's salt in water (22 wt\%, $15 \mathrm{~mL}$ ), dried over anhydrous $\mathrm{Na}_{2} \mathrm{SO}_{4}$, and concentrated in vacuo. The crude product was purified on silica gel TLC ( $n$-hexane/ethyl acetate $=5 / 1$ ) to give ethyl 2-(ethylamino)-2-phenylacetate 2 a (4.60 mg, 15\%) and 3a (4.60 mg, 15\%).

(Table 1, entry 10)

Under an argon atmosphere, a solution of $N$-silyl $\alpha$-iminoester 1 a $(37.4 \mathrm{mg}, 0.15 \mathrm{mmol})$ in DME $(0.50 \mathrm{~mL})$ was stirred at room temperature for $5 \mathrm{~min}$, and to it was added $\mathrm{Et}_{2} \mathrm{AlCl}$ in hexane $(0.70 \mathrm{~mL}$, $0.75 \mathrm{mmol}, 1.07 \mathrm{~N}, 5.0$ equiv) slowly. After the mixture was stirred for $9 \mathrm{~h}$, the reaction was quenched with a solution of Rochelle's salt in water (22 wt\%, $5.0 \mathrm{~mL}$ ), and the whole mixture was extracted with ethyl acetate $(10.0 \mathrm{~mL} \times 3)$. The combined extracts were washed with a solution of Rochelle's salt in water $\left(22 \mathrm{wt} \%, 15 \mathrm{~mL}\right.$ ), dried over anhydrous $\mathrm{Na}_{2} \mathrm{SO}_{4}$, and concentrated in vacuo. The crude product was purified on silica gel TLC ( $n$-hexane/ethyl acetate $=5 / 1$ ) to give ethyl 2-(ethylamino)-2-phenylacetate $\mathbf{2 a}(9.44 \mathrm{mg}, 30 \%)$ and $3 \mathbf{3}(6.16 \mathrm{mg}, 20 \%)$.

(Table 1, entry 11)

Under an argon atmosphere, a solution of $N$-silyl $\alpha$-iminoester 1 a $(37.4 \mathrm{mg}, 0.15 \mathrm{mmol}$ ) in 1,4-dioxane $\left(0.50 \mathrm{~mL}\right.$ ) was stirred at room temperature for $5 \mathrm{~min}$, and to it was added $\mathrm{Et}_{2} \mathrm{AlCl}$ in hexane $(0.70 \mathrm{~mL}, 0.75 \mathrm{mmol}, 1.07 \mathrm{~N}, 5.0$ equiv) slowly. After the mixture was stirred for $3 \mathrm{~h}$, the 
reaction was quenched with a solution of Rochelle's salt in water ( $22 \mathrm{wt} \%, 5.0 \mathrm{~mL}$ ), and the whole mixture was extracted with ethyl acetate $(10.0 \mathrm{~mL} \times 3)$. The combined extracts were washed with a solution of Rochelle's salt in water $(22 \mathrm{wt} \%, 15 \mathrm{~mL})$, dried over anhydrous $\mathrm{Na}_{2} \mathrm{SO}_{4}$, and concentrated in vacuo. The crude product was purified on silica gel TLC ( $n$-hexane/ethyl acetate $=5 / 1$ ) to give ethyl 2-(ethylamino)-2-phenylacetate 2 a (13.8 mg, 44\%) and 3a (4.10 mg, 13\%).

(Table 1, entry 12)

Under an argon atmosphere, a solution of $\mathrm{N}$-silyl $\alpha$-iminoester 1 a $(37.4 \mathrm{mg}, 0.15 \mathrm{mmol})$ in CPME $(0.50 \mathrm{~mL})$ was stirred at room temperature for $5 \mathrm{~min}$, and to it was added $\mathrm{Et}_{2} \mathrm{AlCl}$ in hexane $(0.70 \mathrm{~mL}$, $0.75 \mathrm{mmol}, 1.07 \mathrm{~N}, 5.0$ equiv) slowly. After the mixture was stirred for $3 \mathrm{~h}$, the reaction was quenched with a solution of Rochelle's salt in water $(22 \mathrm{wt} \%, 5.0 \mathrm{~mL}$ ), and the whole mixture was extracted with ethyl acetate $(10.0 \mathrm{~mL} \times 3)$. The combined extracts were washed with a solution of Rochelle's salt in water $\left(22 \mathrm{wt} \%, 15 \mathrm{~mL}\right.$ ), dried over anhydrous $\mathrm{Na}_{2} \mathrm{SO}_{4}$, and concentrated in vacuo. The crude product was purified on silica gel TLC ( $n$-hexane/ethyl acetate $=5 / 1$ ) to give ethyl 2-(ethylamino)-2-phenylacetate 2 a (7.34 mg, 24\%) and 3 a (7.76 mg, 25\%).

(Table 1, entry 13)

Under an argon atmosphere, a solution of $N$-silyl $\alpha$-iminoester 1 a $(37.4 \mathrm{mg}, 0.15 \mathrm{mmol})$ in TBME $(0.50 \mathrm{~mL})$ was stirred at room temperature for $5 \mathrm{~min}$, and to it was added $\mathrm{Et}_{2} \mathrm{AlCl}$ in hexane $(0.70 \mathrm{~mL}$, $0.75 \mathrm{mmol}, 1.07 \mathrm{~N}, 5.0$ equiv) slowly. After the mixture was stirred for $3 \mathrm{~h}$, the reaction was quenched with a solution of Rochelle's salt in water $(22 \mathrm{wt} \%, 5.0 \mathrm{~mL}$ ), and the whole mixture was extracted with ethyl acetate $(10.0 \mathrm{~mL} \times 3)$. The combined extracts were washed with a solution of Rochelle's salt in water $\left(22 \mathrm{wt} \%, 15 \mathrm{~mL}\right.$ ), dried over anhydrous $\mathrm{Na}_{2} \mathrm{SO}_{4}$, and concentrated in vacuo. The crude product was purified on silica gel TLC ( $n$-hexane/ethyl acetate $=5 / 1$ ) to give ethyl 2-(ethylamino)-2-phenylacetate 2a (8.00 mg, 26\%) and 3a (13.2 mg, 42\%).

(Table 1, entry 14)

Under an argon atmosphere, a solution of $\mathrm{N}$-silyl $\alpha$-iminoester $1 \mathrm{a}$ ( $37.4 \mathrm{mg}, 0.15 \mathrm{mmol})$ in THF (0.50 $\mathrm{mL}$ ) was stirred at room temperature for $5 \mathrm{~min}$, and to it was added $\mathrm{Et}_{2} \mathrm{AICl}$ in hexane $(0.70 \mathrm{~mL}, 0.75$ mmol, $1.07 \mathrm{~N}, 5.0$ equiv) slowly. After the mixture was stirred for $3 \mathrm{~h}$, the reaction was quenched with a solution of Rochelle's salt in water $(22 \mathrm{wt} \%, 5.0 \mathrm{~mL})$, and the whole mixture was extracted with ethyl acetate $(10.0 \mathrm{~mL} \times 3)$. The combined extracts were washed with a solution of Rochelle's salt in water $\left(22 \mathrm{wt} \%, 15 \mathrm{~mL}\right.$ ), dried over anhydrous $\mathrm{Na}_{2} \mathrm{SO}_{4}$, and concentrated in vacuo. The crude product was purified on silica gel TLC ( $n$-hexane/ethyl acetate $=5 / 1$ ) to give ethyl 2-(ethylamino)-2-phenylacetate $\mathbf{2 a}$ (18.9 mg, 60\%) and 3a (0.40 mg, 1\%).

(Table 1, entry 15)

Under an argon atmosphere, a solution of $\mathrm{N}$-silyl $\alpha$-iminoester $1 \mathrm{a}$ (37.4 mg, $0.15 \mathrm{mmol}$ ) in 2-MeTHF $(0.50 \mathrm{~mL})$ was stirred at room temperature for $5 \mathrm{~min}$, and to it was added $\mathrm{Et}_{2} \mathrm{AlCl}$ in hexane $(0.70 \mathrm{~mL}$, $0.75 \mathrm{mmol}, 1.07 \mathrm{~N}, 5.0$ equiv) slowly. After the mixture was stirred for $4 \mathrm{~h}$, the reaction was quenched with a solution of Rochelle's salt in water $(22 \mathrm{wt} \%, 5.0 \mathrm{~mL})$, and the whole mixture was extracted with ethyl acetate $(10.0 \mathrm{~mL} \times 3)$. The combined extracts were washed with a solution of Rochelle's salt in water $\left(22 \mathrm{wt} \%, 15 \mathrm{~mL}\right.$ ), dried over anhydrous $\mathrm{Na}_{2} \mathrm{SO}_{4}$, and concentrated in vacuo. The crude product was purified on silica gel TLC ( $n$-hexane/ethyl acetate $=5 / 1$ ) to give ethyl 
2-(ethylamino)-2-phenylacetate $\mathbf{2 a}(19.2 \mathrm{mg}, 62 \%)$ and $\mathbf{3 a}(0.50 \mathrm{mg}, 2 \%)$.

(Table 1, entry 16)

Under an argon atmosphere, a solution of $N$-silyl $\alpha$-iminoester $1 \mathrm{a}(37.4 \mathrm{mg}, 0.15 \mathrm{mmol}$ ) in undistilled 2-MeTHF $(0.50 \mathrm{~mL})$ was stirred at room temperature for $5 \mathrm{~min}$, and to it was added $\mathrm{Et}_{2} \mathrm{AlCl}$ in hexane $(0.70 \mathrm{~mL}, 0.75 \mathrm{mmol}, 1.07 \mathrm{~N}, 5.0$ equiv) slowly. After the mixture was stirred for $3 \mathrm{~h}$, the reaction was quenched with a solution of Rochelle's salt in water ( $22 \mathrm{wt} \%, 5.0 \mathrm{~mL}$ ), and the whole mixture was extracted with ethyl acetate $(10.0 \mathrm{~mL} \times 3)$. The combined extracts were washed with a solution of Rochelle's salt in water $(22 \mathrm{wt} \%, 15 \mathrm{~mL})$, dried over anhydrous $\mathrm{Na}_{2} \mathrm{SO}_{4}$, and concentrated in vacuo. The crude product was purified on silica gel TLC ( $n$-hexane/ethyl acetate $=5 / 1$ ) to give ethyl 2-(ethylamino)-2-phenylacetate 2 a (17.0 mg, 55\%) and $\mathbf{3 a}(1.3 \mathrm{mg}, 4 \%)$.

(Table 1, entry 17)

Under an argon atmosphere, a solution of $N$-silyl $\alpha$-iminoester 1 a (37.4 mg, $0.15 \mathrm{mmol}$ ) in degassed 2-MeTHF $(0.50 \mathrm{~mL})$ was stirred at room temperature for $5 \mathrm{~min}$, and to it was added $\mathrm{Et}_{2} \mathrm{AlCl}$ in hexane $(0.70 \mathrm{~mL}, 0.75 \mathrm{mmol}, 1.07 \mathrm{~N}, 5.0$ equiv) slowly. After the mixture was stirred for $3 \mathrm{~h}$, the reaction was quenched with a solution of Rochelle's salt in water (22 wt\%, $5.0 \mathrm{~mL}$ ), and the whole mixture was extracted with ethyl acetate $(10.0 \mathrm{~mL} \times 3)$. The combined extracts were washed with a solution of Rochelle's salt in water $(22 \mathrm{wt} \%, 15 \mathrm{~mL})$, dried over anhydrous $\mathrm{Na}_{2} \mathrm{SO}_{4}$, and concentrated in vacuo. The crude product was purified on silica gel TLC ( $n$-hexane/ethyl acetate $=5 / 1$ ) to give ethyl 2-(ethylamino)-2-phenylacetate $\mathbf{2 a}(19.8 \mathrm{mg}, 64 \%)$ and 3 a (0.40 mg, 1\%).

\section{4. [Table S2] Examination of Nucleophiles for $\mathbf{N}$-Alkylation of $\boldsymbol{N}$-Silyl $\boldsymbol{\alpha}$-Iminoester}

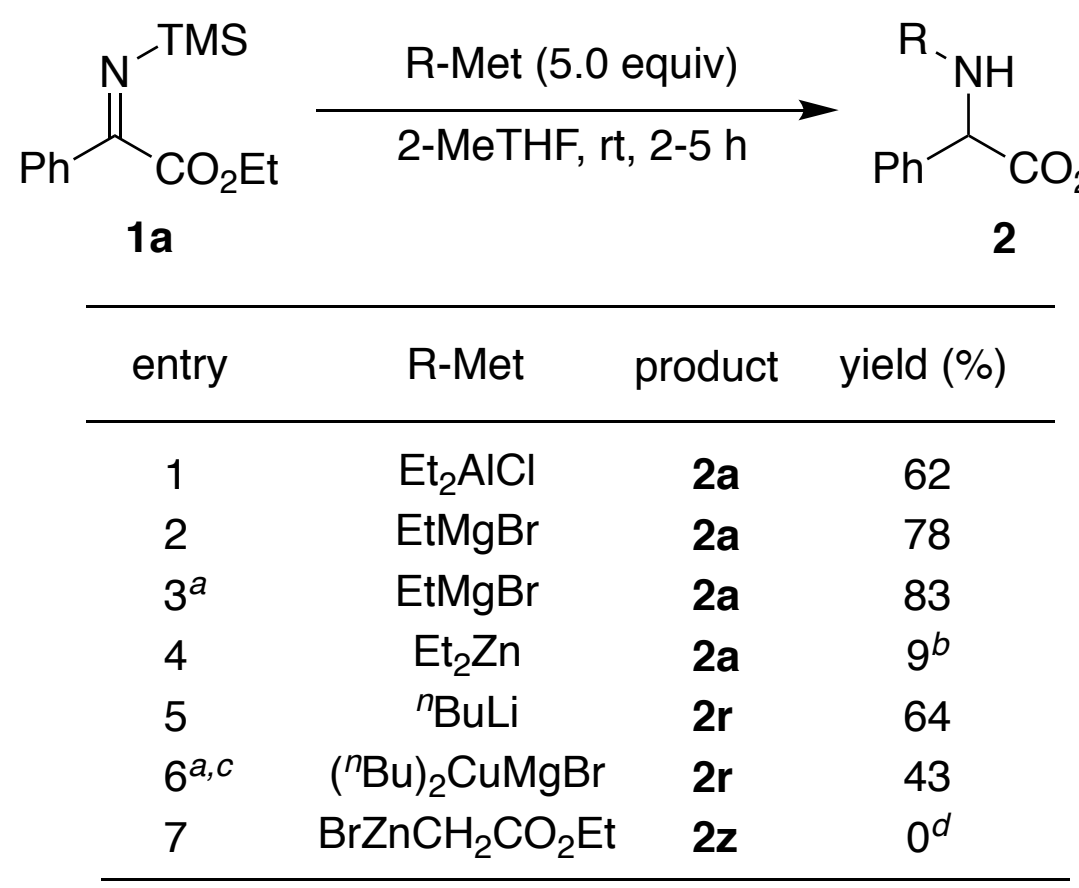

${ }^{a}$ DMF was used as a solvent.

${ }^{b}$ Ethyl benzoylformate was obtained in $55 \%$ yield.

${ }^{c}$ R-Met (3.0 equiv) was used.

${ }^{d}$ C-Alkylated product $\mathbf{3 b}$ was obtained in $54 \%$ yield. 
(Table S2, entry 1): Same as in entry 15, Table 1.

(Table S2, entry 2)

Under an argon atmosphere, a solution of $\mathrm{N}$-silyl $\alpha$-iminoester $1 \mathrm{a}$ ( $37.4 \mathrm{mg}, 0.15 \mathrm{mmol}$ ) in 2-MeTHF $(0.50 \mathrm{~mL})$ was stirred at room temperature for $5 \mathrm{~min}$, and to it was added $\mathrm{EtMgBr}$ in $\mathrm{THF}(0.77 \mathrm{~mL}$, $0.75 \mathrm{mmol}, 0.98 \mathrm{~N}, 5.0$ equiv) slowly. After the mixture was stirred for $3 \mathrm{~h}$, the reaction was quenched with sat. $\mathrm{NaHCO}_{3}$ aq. $(5.0 \mathrm{~mL})$, and the whole mixture was extracted with ethyl acetate (10.0 $\mathrm{mL} \times$ 3). The combined extracts were washed with a solution of sat. $\mathrm{NaHCO}_{3}$ aq. $(15 \mathrm{~mL})$, dried over anhydrous $\mathrm{Na}_{2} \mathrm{SO}_{4}$, and concentrated in vacuo. The crude product was purified on silica gel TLC ( $n$-hexane/ethyl acetate $=5 / 1$ ) to give ethyl 2-(ethylamino)-2-phenylacetate 2 a $(24.1 \mathrm{mg}, 78 \%)$.

(Table S2, entry 3)

Under an argon atmosphere, a solution of $N$-silyl $\alpha$-iminoester 1a (37.4 mg, $0.15 \mathrm{mmol}$ ) in DMF $(0.50 \mathrm{~mL})$ was stirred at room temperature for $5 \mathrm{~min}$, and to it was added EtMgBr in THF $(0.83 \mathrm{~mL}$, $0.75 \mathrm{mmol}, 0.90 \mathrm{~N}, 5.0$ equiv) slowly. After the mixture was stirred for $3 \mathrm{~h}$, the reaction was quenched with sat. $\mathrm{NaHCO}_{3}$ aq. $(5.0 \mathrm{~mL})$, and the whole mixture was extracted with ethyl acetate $(10.0 \mathrm{~mL} \times 3)$. The combined extracts were washed with a solution of sat. $\mathrm{NaHCO}_{3}$ aq. $(15 \mathrm{~mL})$, dried over anhydrous $\mathrm{Na}_{2} \mathrm{SO}_{4}$, and concentrated in vacuo. The crude product was purified on silica gel TLC ( $n$-hexane/ethyl acetate $=5 / 1)$ to give ethyl 2-(ethylamino)-2-phenylacetate 2 a $(25.8 \mathrm{mg}, 83 \%)$.

(Table S2, entry 4)

Under an argon atmosphere, a solution of $N$-silyl $\alpha$-iminoester 1 a $(37.4 \mathrm{mg}, 0.15 \mathrm{mmol})$ in 2-MeTHF $(0.50 \mathrm{~mL})$ was stirred at room temperature for $5 \mathrm{~min}$, and to it was added $\mathrm{Et}_{2} \mathrm{Zn}$ in hexane $(0.75 \mathrm{~mL}$, $0.75 \mathrm{mmol}, 1.00 \mathrm{~N}, 5.0$ equiv) slowly. After the mixture was stirred for $3 \mathrm{~h}$, the reaction was quenched with sat. $\mathrm{NaHCO}_{3}$ aq. $(5.0 \mathrm{~mL})$, and the whole mixture was extracted with ethyl acetate $(10.0 \mathrm{~mL} \times 3)$. The combined extracts were washed with a solution of sat. $\mathrm{NaHCO}_{3}$ aq. $(15 \mathrm{~mL})$, dried over anhydrous $\mathrm{Na}_{2} \mathrm{SO}_{4}$, and concentrated in vacuo. The crude product was purified on silica gel TLC ( $n$-hexane/ethyl acetate $=5 / 1$ ) to give ethyl 2-(ethylamino)-2-phenylacetate 2 a $(2.90 \mathrm{mg}, 9 \%)$ and ethyl benzoylformate (14.6 $\mathrm{mg}, 55 \%)$.

(Table S2, entry 5)

Under an argon atmosphere, a solution of $\mathrm{N}$-silyl $\alpha$-iminoester $1 \mathrm{a}$ (37.4 mg, $0.15 \mathrm{mmol}$ ) in 2-MeTHF $(0.50 \mathrm{~mL})$ was stirred at room temperature for $5 \mathrm{~min}$, and to it was added ${ }^{n} \mathrm{BuLi}$ in hexane $(0.45 \mathrm{~mL}$, $0.75 \mathrm{mmol}, 1.67 \mathrm{~N}, 5.0$ equiv) slowly. After the mixture was stirred for $3 \mathrm{~h}$, the reaction was quenched with sat. $\mathrm{NaHCO}_{3}$ aq. $(5.0 \mathrm{~mL})$, and the whole mixture was extracted with ethyl acetate $(10.0 \mathrm{~mL} \times 3)$. The combined extracts were washed with a solution of sat. $\mathrm{NaHCO}_{3}$ aq. $(15 \mathrm{~mL})$, dried over anhydrous $\mathrm{Na}_{2} \mathrm{SO}_{4}$, and concentrated in vacuo. The crude product was purified on silica gel TLC ( $n$-hexane/ethyl acetate $=5 / 1$ ) to give ethyl 2-(butylamino)-2-phenylacetate $2 r(23.0 \mathrm{mg}, 64 \%$ ).

Ethyl 2-(butylamino)-2-phenylacetate (2r) 


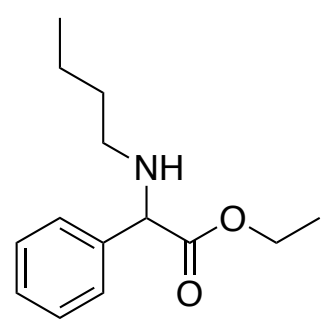

Yield 64\%; brown oil; ${ }^{1} \mathrm{H}$ NMR $\left(500 \mathrm{MHz}, \mathrm{CDCl}_{3}\right) \delta$ 7.34-7.26 (m, 5H), $4.34(\mathrm{~s}, 1 \mathrm{H}), 4.20(\mathrm{dq}, J=7.2$, $11.0 \mathrm{~Hz}, 1 \mathrm{H}), 4.12(\mathrm{dq}, J=7.2,11.0 \mathrm{~Hz}, 1 \mathrm{H}), 2.58(\mathrm{dt}, J=7.2,11.0 \mathrm{~Hz}, 1 \mathrm{H}), 2.50(\mathrm{dt}, J=7.2,11.0 \mathrm{~Hz}, 1 \mathrm{H})$, 1.97 (brs, $1 \mathrm{H}), 1.53-1.47(\mathrm{~m}, 2 \mathrm{H}), 1.38-1.30(\mathrm{~m}, 2 \mathrm{H}), 1.21$ (dd, $J=7.2,7.2 \mathrm{~Hz}, 3 \mathrm{H}), 0.89$ (dd, $J=7.2,7.2$ $\mathrm{Hz}, 3 \mathrm{H}) ;{ }^{13} \mathrm{C}$ NMR $\left(125 \mathrm{MHz}, \mathrm{CDCl}_{3}\right) \delta 173.2,138.4,128.6,127.9,127.3,65.6,61.1,47.5,32.1,20.4$, 14.1, 13.9; IR (neat) 3335, 2958, 2930, 2872, 1735, 1455, 1368, 1176, 1124, 1027, 730, $698 \mathrm{~cm}^{-1}$; HRMS (EI): Calced for $\mathrm{C}_{14} \mathrm{H}_{21} \mathrm{NO}_{2}(\mathrm{M})^{+} 235.1572$, found 235.1565 .

\section{(Table S2, entry 6)}

Under an argon atmosphere, a solution of $N$-silyl $\alpha$-iminoester 1a $(37.4 \mathrm{mg}, 0.15 \mathrm{mmol})$ in DMF $(0.50 \mathrm{~mL})$ was stirred at room temperature for $5 \mathrm{~min}$, and to it was added $\left({ }^{n} \mathrm{Bu}\right){ }_{2} \mathrm{CuMgBr}(0.45 \mathrm{mmol}$, 3.0 equiv), which was prepared from $\mathrm{CuBr}(64.6 \mathrm{mg}, 0.45 \mathrm{mmol})$ and ${ }^{n} \mathrm{BuMgBr}$ in THF $(1.45 \mathrm{~mL}, 0.90$ $\mathrm{mmol}, 0.62 \mathrm{~N})$ in THF (2.69 mL) at -78 to $-15^{\circ} \mathrm{C}$ for $15 \mathrm{~min}$, slowly. After the mixture was stirred for $5 \mathrm{~h}$, the reaction was quenched with sat. $\mathrm{NaHCO}_{3}$ aq. $(5.0 \mathrm{~mL})$, and the whole mixture was extracted with ethyl acetate $(10.0 \mathrm{~mL} \times 3)$. The combined extracts were washed with a solution of sat. $\mathrm{NaHCO}_{3}$ aq. (15 mL), dried over anhydrous $\mathrm{Na}_{2} \mathrm{SO}_{4}$, and concentrated in vacuo. The crude product was purified on silica gel TLC ( $n$-hexane/ethyl acetate $=5 / 1$ ) to give ethyl 2-(butylamino)-2-phenylacetate $2 r$ (15.1 $\mathrm{mg}, 43 \%)$.

(Table S2, entry 7)

Under an argon atmosphere, a solution of $\mathrm{N}$-silyl $\alpha$-iminoester $1 \mathrm{a}(37.4 \mathrm{mg}, 0.15 \mathrm{mmol})$ in 2-MeTHF $(0.50 \mathrm{~mL})$ was stirred at room temperature for $5 \mathrm{~min}$, and to it was added (2-ethoxy-2-oxoethyl)zinc(II) bromide in THF $(0.91 \mathrm{~mL}, 0.75 \mathrm{mmol}, 0.82 \mathrm{~N}, 5.0$ equiv) slowly. After the mixture was stirred for $3 \mathrm{~h}$, the reaction was quenched with sat. $\mathrm{NaHCO}_{3}$ aq. $(5.0 \mathrm{~mL})$, and the whole mixture was extracted with ethyl acetate $(10.0 \mathrm{~mL} \times 3)$. The combined extracts were washed with a solution of sat. $\mathrm{NaHCO}_{3}$ aq. (15 mL), dried over anhydrous $\mathrm{Na}_{2} \mathrm{SO}_{4}$, and concentrated in vacuo. The crude product was purified on silica gel TLC ( $n$-hexane/ethyl acetate $=5 / 1$ ) to give diethyl 2-amino-2-phenylsuccinate $\mathbf{3 b}$ (21.4 mg, 54\%).

Diethyl 2-amino-2-phenylsuccinate (3b)<smiles>CCOC(=O)CC(N)(C(=O)OCC)c1ccccc1</smiles> 
Yield 54\%; Yellow oil; ${ }^{1} \mathrm{H}$ NMR (400 MHz, $\left.\mathrm{CDCl}_{3}\right) \delta$ 7.54-7.50 (m, 2H), 7.37-7.27 (m, 3H), 4.22 (q, J = 7.1 $\mathrm{Hz}, 2 \mathrm{H}), 4.15(\mathrm{q}, J=7.1 \mathrm{~Hz}, 2 \mathrm{H}), 3.30(\mathrm{~d}, J=1.7 \mathrm{~Hz}, 1 \mathrm{H}), 2.81(\mathrm{~d}, J=1.7 \mathrm{~Hz}, 1 \mathrm{H}), 2.53(\mathrm{brs}, 2 \mathrm{H}), 1.25(\mathrm{t}, J$ $=7.1 \mathrm{~Hz}, 3 \mathrm{H}), 1.24(\mathrm{t}, J=7.1 \mathrm{~Hz}, 3 \mathrm{H}) ;{ }^{13} \mathrm{C} \mathrm{NMR}\left(100 \mathrm{MHz}, \mathrm{CDCl}_{3}\right) \delta 175.0,171.6,141.9,128.6,127.8$, 125.1, 62.1, 61.6, 60.7, 44.9, 14.1, 14.0; IR (neat) 3387, 3318, 3061, 2982, 1730, 1601, 1185, 1053, 1030, 771, $729 \mathrm{~cm}^{-1}$; HRMS (EI): Calced for $\mathrm{C}_{11} \mathrm{H}_{14} \mathrm{NO}_{2}\left(\mathrm{M}-\mathrm{C}_{3} \mathrm{H}_{5} \mathrm{O}_{2}\right)^{+} 192.1025$, found 192.1027.

\section{5. [Table S3] Examination of the Amount of Nucleophile for the $\mathrm{N}$-Alkylation of $\mathrm{N}$-Silyl $\alpha$-Iminoester}

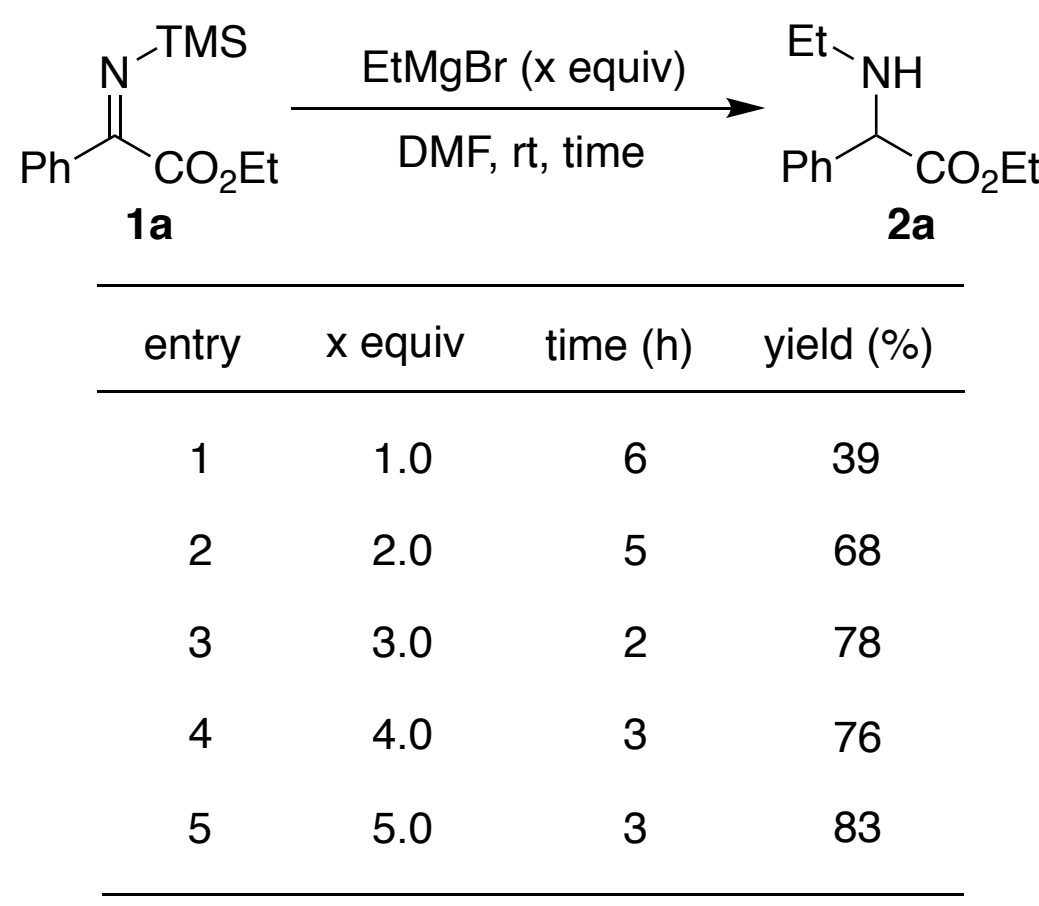

(Table S3, entry 1)

Under an argon atmosphere, a solution of $N$-silyl $\alpha$-iminoester $1 \mathrm{a}(37.4 \mathrm{mg}, 0.15 \mathrm{mmol})$ in DMF $(0.50 \mathrm{~mL})$ was stirred at room temperature for $5 \mathrm{~min}$, and to it was added $\mathrm{EtMgBr}$ in $\mathrm{THF}(0.17 \mathrm{~mL}$, $0.15 \mathrm{mmol}, 0.90 \mathrm{~N}, 1.0$ equiv) slowly. After the mixture was stirred for $6 \mathrm{~h}$, the reaction was quenched with sat. $\mathrm{NaHCO}_{3}$ aq. $(5.0 \mathrm{~mL})$, and the whole mixture was extracted with ethyl acetate $(10.0 \mathrm{~mL} \times 3)$. The combined extracts were washed with a solution of sat. $\mathrm{NaHCO}_{3}$ aq. $(15 \mathrm{~mL})$, dried over anhydrous $\mathrm{Na}_{2} \mathrm{SO}_{4}$, and concentrated in vacuo. The crude product was purified on silica gel TLC ( $n$-hexane/ethyl acetate $=5 / 1)$ to give ethyl 2-(ethylamino)-2-phenylacetate $2 \mathrm{a}(12.1 \mathrm{mg}, 39 \%)$.

(Table S3, entry 2)

Under an argon atmosphere, a solution of $N$-silyl $\alpha$-iminoester 1 a $(37.4 \mathrm{mg}, 0.15 \mathrm{mmol})$ in DMF $(0.50 \mathrm{~mL})$ was stirred at room temperature for $5 \mathrm{~min}$, and to it was added $\mathrm{EtMgBr}$ in $\mathrm{THF}(0.33 \mathrm{~mL}$, $0.30 \mathrm{mmol}, 0.90 \mathrm{~N}, 2.0$ equiv) slowly. After the mixture was stirred for $5 \mathrm{~h}$, the reaction was quenched with sat. $\mathrm{NaHCO}_{3}$ aq. $(5.0 \mathrm{~mL})$, and the whole mixture was extracted with ethyl acetate $(10.0 \mathrm{~mL} \times 3)$. The combined extracts were washed with a solution of sat. $\mathrm{NaHCO}_{3}$ aq. $(15 \mathrm{~mL})$, dried over anhydrous $\mathrm{Na}_{2} \mathrm{SO}_{4}$, and concentrated in vacuo. The crude product was purified on silica gel TLC ( $n$-hexane/ethyl acetate $=5 / 1)$ to give ethyl 2-(ethylamino)-2-phenylacetate 2 a $(21.1 \mathrm{mg}, 68 \%)$.

(Table S3, entry 3) 
Under an argon atmosphere, a solution of $N$-silyl $\alpha$-iminoester 1 a $(37.4 \mathrm{mg}, 0.15 \mathrm{mmol}$ ) in DMF $(0.50 \mathrm{~mL})$ was stirred at room temperature for $5 \mathrm{~min}$, and to it was added $\mathrm{EtMgBr}$ in THF $(0.50 \mathrm{~mL}$, $0.45 \mathrm{mmol}, 0.90 \mathrm{~N}, 3.0$ equiv) slowly. After the mixture was stirred for $2 \mathrm{~h}$, the reaction was quenched with sat. $\mathrm{NaHCO}_{3}$ aq. $(5.0 \mathrm{~mL})$, and the whole mixture was extracted with ethyl acetate $(10.0 \mathrm{~mL} \times 3)$. The combined extracts were washed with a solution of sat. $\mathrm{NaHCO}_{3}$ aq. $(15 \mathrm{~mL})$, dried over anhydrous $\mathrm{Na}_{2} \mathrm{SO}_{4}$, and concentrated in vacuo. The crude product was purified on silica gel TLC ( $n$-hexane/ethyl acetate $=5 / 1$ ) to give ethyl 2-(ethylamino)-2-phenylacetate 2 a $(24.3 \mathrm{mg}, 78 \%)$.

(Table S3, entry 4)

Under an argon atmosphere, a solution of $N$-silyl $\alpha$-iminoester 1 a $(37.4 \mathrm{mg}, 0.15 \mathrm{mmol}$ ) in DMF $(0.50 \mathrm{~mL})$ was stirred at room temperature for $5 \mathrm{~min}$, and to it was added EtMgBr in THF $(0.67 \mathrm{~mL}$, $0.60 \mathrm{mmol}, 0.90 \mathrm{~N}, 4.0$ equiv) slowly. After the mixture was stirred for $3 \mathrm{~h}$, the reaction was quenched with sat. $\mathrm{NaHCO}_{3}$ aq. $(5.0 \mathrm{~mL})$, and the whole mixture was extracted with ethyl acetate $(10.0 \mathrm{~mL} \times 3)$. The combined extracts were washed with a solution of sat. $\mathrm{NaHCO}_{3}$ aq. $(15 \mathrm{~mL})$, dried over anhydrous $\mathrm{Na}_{2} \mathrm{SO}_{4}$, and concentrated in vacuo. The crude product was purified on silica gel TLC ( $n$-hexane/ethyl acetate $=5 / 1$ ) to give ethyl 2-(ethylamino)-2-phenylacetate 2 a $(23.6 \mathrm{mg}, 76 \%)$.

(Table S3, entry 5): Same as in entry 7, Table S2.

\section{6. [Scheme 2] Scope of Substrates for $N$-Alkylation of $N$-Silyl $\alpha$-Iminoester}

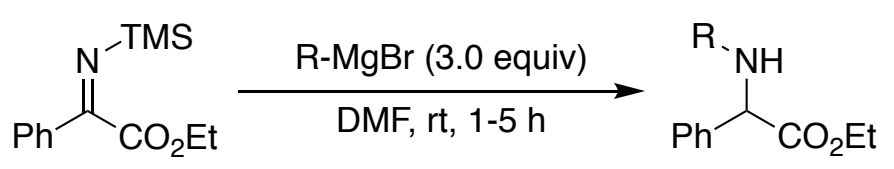

$1 \mathrm{a}$

2

\section{Synthesis of ethyl 2-(ethylamino)-2-phenylacetate (2a)}

(In the case of 3.0 equiv of Grignard): Same as in entry 3, Table S3.

(In the case of 5.0 equiv of Grignard): Same as in entry 5, Table S3.

\section{Synthesis of methyl 2-(ethylamino)-2-phenylacetate (2b)}

Under an argon atmosphere, a solution of $N$-silyl $\alpha$-iminoester $\mathbf{1 b}(35.3 \mathrm{mg}, 0.15 \mathrm{mmol})$ in DMF $(0.50 \mathrm{~mL})$ was stirred at room temperature for $5 \mathrm{~min}$, and to it was added EtMgBr in THF $(0.77 \mathrm{~mL}$, $0.75 \mathrm{mmol}, 0.98 \mathrm{~N}, 5.0$ equiv) slowly. After the mixture was stirred for $3 \mathrm{~h}$, the reaction was quenched with sat. $\mathrm{NaHCO}_{3}$ aq. $(5.0 \mathrm{~mL})$, and the whole mixture was extracted with ethyl acetate $(10.0 \mathrm{~mL} \times 3)$. The combined extracts were washed with a solution of sat. $\mathrm{NaHCO}_{3}$ aq. $(15 \mathrm{~mL})$, dried over anhydrous $\mathrm{Na}_{2} \mathrm{SO}_{4}$, and concentrated in vacuo. The crude product was purified on silica gel TLC ( $n$-hexane/ethyl acetate $=5 / 1$ ) to give the title compound $\mathbf{2 b}(23.1 \mathrm{mg}, 80 \%)$.

Methyl 2-(ethylamino)-2-phenylacetate (2b) 
<smiles>CCNC(C(=O)OC)c1ccccc1</smiles>

Yield 80\% (2 steps); Yellow oil; ${ }^{1} \mathrm{H}$ NMR (400 MHz, $\left.\mathrm{CDCl}_{3}\right) \delta$ 7.39-7.25 (m, 5H), $4.38(\mathrm{~s}, 1 \mathrm{H}), 3.69(\mathrm{~s}, 3 \mathrm{H})$, $2.63(\mathrm{dq}, J=7.1,10.9 \mathrm{~Hz}, 1 \mathrm{H}$ ), 2.55 (dq, $J=7.1,10.9 \mathrm{~Hz}, 1 \mathrm{H}), 1.92$ (brs, $1 \mathrm{H}), 1.13$ (dd, J = 7.1, $7.1 \mathrm{~Hz}$, $3 \mathrm{H}) ;{ }^{13} \mathrm{C} \mathrm{NMR}\left(125 \mathrm{MHz}, \mathrm{CDCl}_{3}\right) \delta 173.6,138.2,128.7,128.0,127.3,65.4,52.1,42.0,15.1$; IR (neat) 3333, 2966, 2895, 2844, 1739, 1496, 1453, 1433, 1209, 1169, 984, 733, $697 \mathrm{~cm}^{-1}$; HRMS (EI): Calcd for $\mathrm{C}_{9} \mathrm{H}_{12} \mathrm{~N}\left(\mathrm{M}-\mathrm{C}_{2} \mathrm{H}_{3} \mathrm{O}_{2}\right)^{+}$134.0970, found 134.0959.

\section{Synthesis of isopropyl 2-(ethylamino)-2-phenylacetate (2c)}

Under an argon atmosphere, a solution of $N$-silyl $\alpha$-iminoester $1 \mathrm{c}(39.5 \mathrm{mg}, 0.15 \mathrm{mmol})$ in DMF (0.50 $\mathrm{mL}$ ) was stirred at room temperature for $5 \mathrm{~min}$, and to it was added $\mathrm{EtMgBr}$ in THF $(0.93 \mathrm{~mL}, 0.75$ mmol, $0.81 \mathrm{~N}, 5.0$ equiv) slowly. After the mixture was stirred for $3 \mathrm{~h}$, the reaction was quenched with sat. $\mathrm{NaHCO}_{3}$ aq. $(5.0 \mathrm{~mL})$, and the whole mixture was extracted with ethyl acetate $(10.0 \mathrm{~mL} \times 3)$. The combined extracts were washed with a solution of sat. $\mathrm{NaHCO}_{3}$ aq. (15 $\mathrm{mL}$ ), dried over anhydrous $\mathrm{Na}_{2} \mathrm{SO}_{4}$, and concentrated in vacuo. The crude product was purified on silica gel TLC ( $n$-hexane/ethyl acetate $=5 / 1)$ to give the title compound $2 \mathrm{c}(22.9 \mathrm{mg}, 69 \%)$.

Isopropyl 2-(ethylamino)-2-phenylacetate (2c)<smiles>CCNC(C(=O)OC(C)C)c1ccccc1</smiles>

Yield 69\%; Yellow oil; ${ }^{1} \mathrm{H}$ NMR (400 MHz, $\left.\mathrm{CDCl}_{3}\right) \delta 7.38-7.25(\mathrm{~m}, 5 \mathrm{H}), 5.03$ (qq, $J=6.1,6.1 \mathrm{~Hz}, 1 \mathrm{H}$ ), 4.32 (s, 1H), 2.64 (dq, J = 7.0, $10.9 \mathrm{~Hz}, 1 \mathrm{H}), 2.56$ (dq, $J=7.0,10.9 \mathrm{~Hz}, 1 \mathrm{H}), 1.92(\mathrm{brs}, 1 \mathrm{H}), 1.24(\mathrm{~d}, J=6.1 \mathrm{~Hz}$, $3 \mathrm{H}), 1.13$ (dd, $J=7.0,7.0 \mathrm{~Hz}, 3 \mathrm{H}), 1.11(\mathrm{~d}, J=6.1 \mathrm{~Hz}, 3 \mathrm{H}) ;{ }^{13} \mathrm{C} \mathrm{NMR}\left(125 \mathrm{MHz}, \mathrm{CDCl}_{3}\right) \delta 172.7,138.4$, $128.5,127.8,127.2,68.5,65.5,42.0,21.8,21.4,15.2$; IR (neat) 3330, 3031, 2978, 1730, 1453, 1377, 1313, 1208, 1177, 1106, 719, $699 \mathrm{~cm}^{-1}$; HRMS(EI): Calcd for $\mathrm{C}_{13} \mathrm{H}_{19} \mathrm{NO}_{2}(\mathrm{M})^{+}$221.1416, found 221.1421.

\section{Synthesis of tert-butyl 2-(ethylamino)-2-phenylacetate (2d)}

Under an argon atmosphere, a solution of $N$-silyl $\alpha$-iminoester $1 \mathbf{d}(27.7 \mathrm{mg}, 0.10 \mathrm{mmol})$ in DMF $(0.50 \mathrm{~mL})$ was stirred at room temperature for $5 \mathrm{~min}$, and to it was added EtMgBr in THF $(0.62 \mathrm{~mL}$, $0.50 \mathrm{mmol}, 0.81 \mathrm{~N}, 5.0$ equiv) slowly. After the mixture was stirred for $1 \mathrm{~h}$, the reaction was quenched with sat. $\mathrm{NaHCO}_{3}$ aq. $(5.0 \mathrm{~mL})$, and the whole mixture was extracted with ethyl acetate $(10.0 \mathrm{~mL} \times 3)$. The combined extracts were washed with a solution of sat. $\mathrm{NaHCO}_{3}$ aq. $(15 \mathrm{~mL})$, dried over anhydrous $\mathrm{Na}_{2} \mathrm{SO}_{4}$, and concentrated in vacuo. The crude product was purified on silica gel TLC ( $n$-hexane/ethyl acetate $=5 / 1$ ) to give the title compound $\mathbf{2 d}(21.0 \mathrm{mg}, 89 \%)$.

tert-Butyl 2-(ethylamino)-2-phenylacetate (2d) 


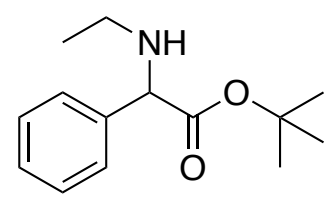

Yield 89\%; Yellow oil; ${ }^{1} \mathrm{H}$ NMR $\left(500 \mathrm{MHz}, \mathrm{CDCl}_{3}\right) \delta 7.36-7,26(\mathrm{~m}, 5 \mathrm{H}), 4.25(\mathrm{~s}, 1 \mathrm{H}), 2.63(\mathrm{dq}, J=7.2,11.0$ $\mathrm{Hz}, 1 \mathrm{H}$ ), 2.55 (dq, $J=7.2,11.0 \mathrm{~Hz}, 1 \mathrm{H}), 1.89$ (brs, $1 \mathrm{H}), 1.39(\mathrm{~s}, 9 \mathrm{H}), 1.13$ (dd, $J=7.2,7.2 \mathrm{~Hz}, 3 \mathrm{H}$ ); ${ }^{13} \mathrm{C}$ NMR $\left(125 \mathrm{MHz} \mathrm{CDCl}_{3}\right) \delta 172.4,138.8,128.5,127.6,127.2,81.4,66.0,42.0,27.9,15.2$; IR (neat) 3332, 2975, 2934, 2872, 1729, 1455, 1392, 1368, 1250, 1216, 1151, 846, 751, $698 \mathrm{~cm}^{-1}$; HRMS (El): Calcd. For $\mathrm{C}_{14} \mathrm{H}_{21} \mathrm{NO}_{2}(\mathrm{M})^{+} 235.1572$, found 235.1582 .

\section{Synthesis of cyclohexyl 2-(ethylamino)-2-phenylacetate (2e)}

Under an argon atmosphere, a solution of $\mathrm{N}$-silyl $\alpha$-iminoester 1 e $(45.5 \mathrm{mg}, 0.15 \mathrm{mmol})$ in DMF $(0.50 \mathrm{~mL})$ was stirred at room temperature for $5 \mathrm{~min}$, and to it was added EtMgBr in THF $(0.56 \mathrm{~mL}$, $0.45 \mathrm{mmol}, 0.80 \mathrm{~N}, 3.0$ equiv) slowly. After the mixture was stirred for $1 \mathrm{~h}$, the reaction was quenched with sat. $\mathrm{NaHCO}_{3}$ aq. $(5.0 \mathrm{~mL})$, and the whole mixture was extracted with ethyl acetate (10.0 $\mathrm{mL} \times$ 3). The combined extracts were washed with a solution of sat. $\mathrm{NaHCO}_{3}$ aq. $(15 \mathrm{~mL})$, dried over anhydrous $\mathrm{Na}_{2} \mathrm{SO}_{4}$, and concentrated in vacuo. The crude product was purified on silica gel TLC ( $n$-hexane/ethyl acetate $=5 / 1)$ to give the title compound 2 e $(30.0 \mathrm{mg}, 77 \%)$.

Cyclohexyl 2-(ethylamino)-2-phenylacetate (2e)

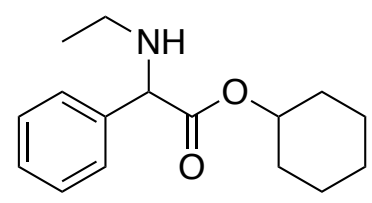

Yield 77\%; Yellow oil; ${ }^{1} \mathrm{H}$ NMR $\left(500 \mathrm{MHz}, \mathrm{CDCl}_{3}\right) \delta$ 7.38-7.26 (m, 5H), 4.82-4.77 (m, $\left.1 \mathrm{H}\right), 4.35(\mathrm{~s}, 1 \mathrm{H})$, $2.64(\mathrm{dq}, J=7.2,11.0 \mathrm{~Hz}, 1 \mathrm{H}), 2.57(\mathrm{dq}, J=7.2,11.0 \mathrm{~Hz}, 1 \mathrm{H}), 2.00-1.88(\mathrm{~m}, 1 \mathrm{H}), 1.88-1.78(\mathrm{~m}, 1 \mathrm{H})$, 1.70-1.66 (m, 2H), 1.54-1.20 (m, 7H), $1.13(\mathrm{dd}, J=7.2,7.2 \mathrm{~Hz}, 3 \mathrm{H}) ;{ }^{13} \mathrm{C} \mathrm{NMR}\left(125 \mathrm{MHz}, \mathrm{CDCl}_{3}\right) \delta 172.6$, $138.5,128.5,127.8,127.2,73.3,65.6,42.0,31.5,31.1,25.2,23.5,23.3,15.2$; IR (neat) 3335, 2936, 2859, 1732, 1448, 1318, 1177, 1128, 1021, 960, 733, $697 \mathrm{~cm}^{-1}$; HRMS (EI): Calcd for $\mathrm{C}_{16} \mathrm{H}_{23} \mathrm{NO}_{2}(\mathrm{M})^{+}$ 261.1729 found 261.1734 .

\section{Synthesis of tert-butyl 2-(ethylamino)-2-(p-tolyl)acetate (2f)}

Under an argon atmosphere, a solution of $N$-silyl $\alpha$-iminoester $1 \mathbf{f}(43.7 \mathrm{mg}, 0.15 \mathrm{mmol})$ in DMF (0.50 $\mathrm{mL}$ ) was stirred at room temperature for $5 \mathrm{~min}$, and to it was added $\mathrm{EtMgBr}$ in THF $(0.51 \mathrm{~mL}, 0.45$ mmol, $0.89 \mathrm{~N}, 3.0$ equiv) slowly. After the mixture was stirred for $3 \mathrm{~h}$, the reaction was quenched with sat. $\mathrm{NaHCO}_{3}$ aq. $(5.0 \mathrm{~mL})$, and the whole mixture was extracted with ethyl acetate $(10.0 \mathrm{~mL} \times 3)$. The combined extracts were washed with a solution of sat. $\mathrm{NaHCO}_{3}$ aq. (15 $\mathrm{mL}$ ), dried over anhydrous $\mathrm{Na}_{2} \mathrm{SO}_{4}$, and concentrated in vacuo. The crude product was purified on silica gel TLC ( $n$-hexane/ethyl acetate $=5 / 1)$ to give the title compound $\mathbf{2 f}(30.6 \mathrm{mg}, 82 \%)$. 
tert-Butyl 2-(ethylamino)-2-( $p$-tolyl)acetate (2f)<smiles>CCNC(C(=O)OC(C)(C)C)c1ccc(C)cc1</smiles>

Yield 81\%; Yellow oil; ${ }^{1} \mathrm{H}$ NMR $\left(500 \mathrm{MHz}, \mathrm{CDCl}_{3}\right) \delta$ 7.24-7.12 (m, 4H), $4.21(\mathrm{~s}, 1 \mathrm{H}), 2.61$ (dq, $J=7.1$, $11.0 \mathrm{~Hz}, 1 \mathrm{H}$ ), 2.54 (dq, $J=7.1,11.0 \mathrm{~Hz}, 1 \mathrm{H}), 2.33(\mathrm{~s}, 3 \mathrm{H}), 1.88$ (brs, $1 \mathrm{H}), 1.39(\mathrm{~s}, 9 \mathrm{H}), 1.12$ (dd, $J=7.1$, $7.1 \mathrm{~Hz}, 3 \mathrm{H}) ;{ }^{13} \mathrm{C} \mathrm{NMR}\left(125 \mathrm{MHz}, \mathrm{CDCl}_{3}\right) \delta 172.6,137.2,135.8,129.2,127.0,81.2,65.6,41.9,27.9,21.1$, 15.2; IR (neat) 3335, 2974, 1729, 1512, 1457, 1368, 1319, 1249, 1153, 1037, 951, 846, $789 \mathrm{~cm}^{-1}$; HRMS (EI): Calcd for $\mathrm{C}_{15} \mathrm{H}_{23} \mathrm{NO}_{2}(\mathrm{M})^{+} 249.1729$ found 249.1719 .

\section{Synthesis of tert-butyl 2-(ethylamino)-2-(m-tolyl)acetate (2g)}

Under an argon atmosphere, a solution of $N$-silyl $\alpha$-iminoester $1 \mathrm{~g}(43.7 \mathrm{mg}, 0.15 \mathrm{mmol})$ in DMF $(0.50 \mathrm{~mL})$ was stirred at room temperature for $5 \mathrm{~min}$, and to it was added EtMgBr in THF $(0.54 \mathrm{~mL}$, $0.45 \mathrm{mmol}, 0.80 \mathrm{~N}, 3.0$ equiv) slowly. After the mixture was stirred for $1 \mathrm{~h}$, the reaction was quenched with sat. $\mathrm{NaHCO}_{3}$ aq. $(5.0 \mathrm{~mL})$, and the whole mixture was extracted with ethyl acetate $(10.0 \mathrm{~mL} \times 3)$. The combined extracts were washed with a solution of sat. $\mathrm{NaHCO}_{3}$ aq. $(15 \mathrm{~mL})$, dried over anhydrous $\mathrm{Na}_{2} \mathrm{SO}_{4}$, and concentrated in vacuo. The crude product was purified on silica gel TLC ( $n$-hexane/ethyl acetate $=5 / 1$ ) to give the title compound $2 \mathrm{~g}(26.2 \mathrm{mg}, 70 \%)$.

tert-Butyl 2-(ethylamino)-2-( $m$-tolyl)acetate $(\mathbf{2 g})$<smiles>CCNC(C(=O)OC(C)(C)C)c1cccc(C)c1</smiles>

Yield 70\%; Yellow oil; ${ }^{1} \mathrm{H}$ NMR $\left(400 \mathrm{MHz}, \mathrm{CDCl}_{3}\right) \delta$ 7.26-7.07 (m, 4H), $4.20(\mathrm{~s}, 1 \mathrm{H}), 2.63$ (dq, $J=7.1$, $11.2 \mathrm{~Hz}, 1 \mathrm{H}), 2.55$ (dq, J = 7.1, $11.2 \mathrm{~Hz}, 1 \mathrm{H}), 2.34$ (s, 3H), 1.89 (brs, 1H), 1.40 (s, 9H), 1.13 (dd, J = 7.1, $7.1 \mathrm{~Hz}, 3 \mathrm{H}) ;{ }^{13} \mathrm{C}$ NMR $\left(100 \mathrm{MHz}, \mathrm{CDCl}_{3}\right) \delta$ 172.5, 138.7, 138.1, 128.4, 128.3, 127.9, 124.2, 81.3, 65.9, 42.0, 27.9, 21.4, 15.2; IR (neat) 3335, 2972, 1728, 1605, 1460, 1373, 1365, 1316, 1249, 1153, 1147, 955, 849, 784, $698 \mathrm{~cm}^{-1}$; HRMS (EI): Calcd for $\mathrm{C}_{11} \mathrm{H}_{14} \mathrm{NO}\left(\mathrm{M}-\mathrm{C}_{4} \mathrm{H}_{9} \mathrm{O}\right)^{+} 176.1075$ found 176.1067 .

\section{Synthesis of tert-butyl 2-(ethylamino)-2-(o-tolyl)acetate (2h)}

Under an argon atmosphere, a solution of $N$-silyl $\alpha$-iminoester $1 \mathbf{h}(43.7 \mathrm{mg}, 0.15 \mathrm{mmol})$ in DMF $(0.50 \mathrm{~mL})$ was stirred at room temperature for $5 \mathrm{~min}$, and to it was added $\mathrm{EtMgBr}$ in THF $(0.51 \mathrm{~mL}$, $0.45 \mathrm{mmol}, 0.89 \mathrm{~N}, 3.0$ equiv) slowly. After the mixture was stirred for $1 \mathrm{~h}$, the reaction was quenched with sat. $\mathrm{NaHCO}_{3}$ aq. $(5.0 \mathrm{~mL})$, and the whole mixture was extracted with ethyl acetate $(10.0 \mathrm{~mL} \times 3)$. The combined extracts were washed with a solution of sat. $\mathrm{NaHCO}_{3}$ aq. $(15 \mathrm{~mL})$, dried over anhydrous $\mathrm{Na}_{2} \mathrm{SO}_{4}$, and concentrated in vacuo. The crude product was purified on silica gel TLC ( $n$-hexane/ethyl acetate $=5 / 1$ ) to give the title compound $\mathbf{2 h}(22.6 \mathrm{mg}, 60 \%)$. 
tert-Butyl 2-(ethylamino)-2-(o-tolyl)acetate (2h)<smiles>CCNC(C(=O)OC(C)(C)C)c1ccccc1C</smiles>

Yield 60\%; Yellow oil; ${ }^{1} \mathrm{H}$ NMR $\left(400 \mathrm{MHz}, \mathrm{CDCl}_{3}\right) \delta$ 7.27-7.15 (m, 4H), $4.48(\mathrm{~s}, 1 \mathrm{H}), 2.66(\mathrm{dq}, J=7.1$, $11.2 \mathrm{~Hz}, 1 \mathrm{H}$ ), 2.54 (dq, J = 7.1, $11.2 \mathrm{~Hz}, 1 \mathrm{H}$ ), 2.43 (s, 3H), 1.88 (brs, 1H), 1.38 (s, 9H), 1.12 (dd, J = 7.1, $7.1 \mathrm{~Hz}, 3 \mathrm{H}) ;{ }^{13} \mathrm{C}$ NMR $\left(100 \mathrm{MHz}, \mathrm{CDCl}_{3}\right) \delta 172.7,137.4,136.4,130.5,127.4,126.2,125.8,81.3,62.0$ 42.2, 27.9, 19.5, 15.3; IR (neat) 3337, 2972, 1729, 1460, 1369, 1320, 1252, 1217, 1152, 1041, 948, 847, 786, $751 \mathrm{~cm}^{-1}$; HRMS (EI): Calcd for $\mathrm{C}_{15} \mathrm{H}_{23} \mathrm{NO}_{2}(\mathrm{M})^{+} 249.1729$ found 249.1723 .

\section{Synthesis of tert-butyl 2-(ethylamino)-2-(4-methoxyphenyl)acetate (2i)}

Under an argon atmosphere, a solution of $N$-silyl $\alpha$-iminoester $1 \mathbf{i}(31.0 \mathrm{mg}, 0.10 \mathrm{mmol})$ in DMF $(0.50$ $\mathrm{mL}$ ) was stirred at room temperature for $5 \mathrm{~min}$, and to it was added $\mathrm{EtMgBr}$ in THF $(0.34 \mathrm{~mL}, 0.30$ mmol, $0.89 \mathrm{~N}, 3.0$ equiv) slowly. After the mixture was stirred for $1 \mathrm{~h}$, the reaction was quenched with sat. $\mathrm{NaHCO}_{3}$ aq. $(5.0 \mathrm{~mL})$, and the whole mixture was extracted with ethyl acetate $(10.0 \mathrm{~mL} \times 3)$. The combined extracts were washed with a solution of sat. $\mathrm{NaHCO}_{3}$ aq. (15 mL), dried over anhydrous $\mathrm{Na}_{2} \mathrm{SO}_{4}$, and concentrated in vacuo. The crude product was purified on silica gel TLC ( $n$-hexane/ethyl acetate $=5 / 1)$ to give the title compound $\mathbf{2 i}(22.6 \mathrm{mg}, 85 \%)$.

tert-Butyl 2-(ethylamino)-2-(4-methoxyphenyl)acetate (2i)

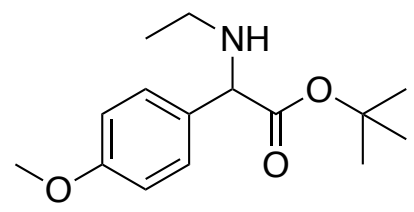

Yield 85\%; Yellow oil; ${ }^{1} \mathrm{H}$ NMR $\left(500 \mathrm{MHz}, \mathrm{CDCl}_{3}\right) \delta$ 7.28-7.26 (m, 2H), 6.88-6.85 (m, 2H), $4.19(\mathrm{~S}, 1 \mathrm{H})$, $3.80(\mathrm{~s}, 3 \mathrm{H}), 2.61(\mathrm{dq}, J=7.1,11.0 \mathrm{~Hz}, 1 \mathrm{H}), 2.54(\mathrm{dq}, J=7.1,11.0 \mathrm{~Hz}, 1 \mathrm{H}), 1.82$ (brs, $1 \mathrm{H}), 1.39(\mathrm{~s}, 9 \mathrm{H})$, 1.12 (dd, $J=7.1,7.1 \mathrm{~Hz}, 3 \mathrm{H}) ;{ }^{13} \mathrm{C}$ NMR $\left(125 \mathrm{MHz}, \mathrm{CDCl}_{3}\right) \delta 172.7,159.0,131.0,128.3,113.8,81.3,65.3$, 55.2, 41.9, 27.9, 15.2; IR (neat) 3300, 2974, 2935, 2838, 1727, 1678, 1605, 1513, 1460, 1368, 1251, 1152, 1034, 836, $797 \mathrm{~cm}^{-1}$; $\mathrm{HRMS}(\mathrm{EI})$ : Calcd. For $\mathrm{C}_{15} \mathrm{H}_{23} \mathrm{NO}_{3}(\mathrm{M})^{+} 265.1678$, found 265.1667 .

\section{Synthesis of tert-butyl 2-(4-chlorophenyl)-2-(ethylamino)acetate (2j)}

Under an argon atmosphere, a solution of $N$-silyl $\alpha$-iminoester $1 \mathbf{j}$ (46.7 mg, $0.15 \mathrm{mmol}$ ) in DMF (0.50 $\mathrm{mL}$ ) was stirred at room temperature for $5 \mathrm{~min}$, and to it was added $\mathrm{EtMgBr}$ in THF $(0.51 \mathrm{~mL}, 0.45$ mmol, $0.89 \mathrm{~N}, 3.0$ equiv) slowly. After the mixture was stirred for $1.5 \mathrm{~h}$, the reaction was quenched with sat. $\mathrm{NaHCO}_{3}$ aq. $(5.0 \mathrm{~mL})$, and the whole mixture was extracted with ethyl acetate $(10.0 \mathrm{~mL} \times 3)$. The combined extracts were washed with a solution of sat. $\mathrm{NaHCO}_{3}$ aq. (15 $\mathrm{mL}$ ), dried over anhydrous $\mathrm{Na}_{2} \mathrm{SO}_{4}$, and concentrated in vacuo. The crude product was purified on silica gel TLC ( $n$-hexane/ethyl acetate $=5 / 1)$ to give the title compound $2 \mathbf{j}(38.2 \mathrm{mg}, 94 \%)$. 
tert-Butyl 2-(4-chlorophenyl)-2-(ethylamino)acetate (2j)<smiles>CCNC(C(=O)OC(C)(C)C)c1ccc(Cl)cc1</smiles>

Yield 94\%; Yellow oil; ${ }^{1} \mathrm{H}$ NMR $\left(400 \mathrm{MHz}, \mathrm{CDCl}_{3}\right) \delta$ 7.37-7.27 (m, 4H), $4.22(\mathrm{~s}, 1 \mathrm{H}), 2.62$ (dq, $J=7.1,11.3$ $\mathrm{Hz}, 1 \mathrm{H}$ ), $2.53(\mathrm{dq}, J=7.1,11.3 \mathrm{~Hz}, 1 \mathrm{H}), 1.92$ (brs, $1 \mathrm{H}), 1.39(\mathrm{~s}, 9 \mathrm{H}), 1.12$ (dd, $J=7.1,7.1 \mathrm{~Hz}, 3 \mathrm{H}) ;{ }^{13} \mathrm{C}$ NMR $\left(125 \mathrm{MHz} \mathrm{CDCl}_{3}\right) \delta$ 172.0, 137.4, 133.4, 128.6, 128.6, 81.7, 65.3, 42.0, 27.9, 15.2; IR (neat) 3334, 2976, 2934, 2872, 1729, 1491, 1369, 1251, 1153, 1090, 1015, 837, $789 \mathrm{~cm}^{-1}$; HRMS (EI): Calcd for $\mathrm{C}_{10} \mathrm{H}_{11} \mathrm{CINO}(\mathrm{M}-\mathrm{C} 4 \mathrm{H} 9 \mathrm{O})+196.0529$ found 196.0523 .

\section{Synthesis of tert-butyl 2-(4-bromophenyl)-2-(ethylamino)acetate (2k)}

Under an argon atmosphere, a solution of $N$-silyl $\alpha$-iminoester $1 \mathbf{k}(53.5 \mathrm{mg}, 0.15 \mathrm{mmol}$ ) in DMF $(0.50 \mathrm{~mL})$ was stirred at room temperature for $5 \mathrm{~min}$, and to it was added EtMgBr in THF $(0.56 \mathrm{~mL}$, $0.45 \mathrm{mmol}, 0.80 \mathrm{~N}, 3.0$ equiv) slowly. After the mixture was stirred for $3 \mathrm{~h}$, the reaction was quenched with sat. $\mathrm{NaHCO}_{3}$ aq. $(5.0 \mathrm{~mL}$ ), and the whole mixture was extracted with ethyl acetate $(10.0 \mathrm{~mL} \times 3)$. The combined extracts were washed with a solution of sat. $\mathrm{NaHCO}_{3}$ aq. $(15 \mathrm{~mL})$, dried over anhydrous $\mathrm{Na}_{2} \mathrm{SO}_{4}$, and concentrated in vacuo. The crude product was purified on silica gel TLC ( $n$-hexane/ethyl acetate $=5 / 1$ ) to give the title compound $\mathbf{2 k}(52.4 \mathrm{mg}$, quant).

tert-Butyl 2-(4-bromophenyl)-2-(ethylamino)acetate (2k)<smiles>CCNC(C(=O)OC(C)(C)C)c1ccc(Br)cc1</smiles>

Yield quant; Yellow oil; ${ }^{1} \mathrm{H}$ NMR (400 MHz, $\left.\mathrm{CDCl}_{3}\right) \delta$ 7.47-7.44 (m, 2H), 7.27-7.23 (m, 2H), $4.20(\mathrm{~s}, 1 \mathrm{H})$, $2.62(\mathrm{dq}, J=7.1,11.0 \mathrm{~Hz}, 1 \mathrm{H}$ ), $2.53(\mathrm{dq}, J=7.1,11.0 \mathrm{~Hz}, 1 \mathrm{H}), 1.88$ (brs, $1 \mathrm{H}$ ), 1.39 (s, 9H), 1.12 (dd, $J=$ 7.1, $7.1 \mathrm{~Hz}, 3 \mathrm{H}) ;{ }^{13} \mathrm{C} \mathrm{NMR}\left(100 \mathrm{MHz}, \mathrm{CDCl}_{3}\right) \delta$ 171.9, 138.0, 131.6, 129.0, 121.6, 81.7, 65.4, 42.0, 27.9, 15.2; IR (neat) 3335, 2972, 2932, 1733, 1480, 1373, 1248, 1152, 1013, 789, $751 \mathrm{~cm}^{-1}$; HRMS (EI): Calcd for $\mathrm{C}_{14} \mathrm{H}_{20} \mathrm{BrNO}_{2}(\mathrm{M})^{+} 313.0677$ found 313.0676 .

\section{Synthesis of tert-butyl 2-(3-bromophenyl)-2-(ethylamino)acetate (2I)}

Under an argon atmosphere, a solution of $N$-silyl $\alpha$-iminoester 1 l $(53.5 \mathrm{mg}, 0.15 \mathrm{mmol})$ in DMF (0.50 $\mathrm{mL}$ ) was stirred at room temperature for $5 \mathrm{~min}$, and to it was added $\mathrm{EtMgBr}$ in THF $(0.56 \mathrm{~mL}, 0.45$ mmol, $0.80 \mathrm{~N}, 3.0$ equiv) slowly. After the mixture was stirred for $1 \mathrm{~h}$, the reaction was quenched with sat. $\mathrm{NaHCO}_{3}$ aq. $(5.0 \mathrm{~mL})$, and the whole mixture was extracted with ethyl acetate $(10.0 \mathrm{~mL} \times 3)$. The combined extracts were washed with a solution of sat. $\mathrm{NaHCO}_{3}$ aq. (15 mL), dried over anhydrous $\mathrm{Na}_{2} \mathrm{SO}_{4}$, and concentrated in vacuo. The crude product was purified on silica gel TLC ( $n$-hexane/ethyl acetate $=5 / 1)$ to give the title compound $\mathbf{2 l}(37.9 \mathrm{mg}, 80 \%)$. 
tert-Butyl 2-(3-bromophenyl)-2-(ethylamino)acetate (2I)<smiles>CCNC(C(=O)OC(C)(C)C)c1cccc(Br)c1</smiles>

Yield 80\%; Yellow oil; ${ }^{1} \mathrm{H}$ NMR $\left(400 \mathrm{MHz}, \mathrm{CDCl}_{3}\right) \delta$ 7.54-7.53 (m, $\left.1 \mathrm{H}\right), 7.42-7.39(\mathrm{~m}, 1 \mathrm{H}), 7.31-7.27(\mathrm{~m}$, $1 \mathrm{H}), 7.21-7.18(\mathrm{~m}, 1 \mathrm{H}), 4.21(\mathrm{~s}, 1 \mathrm{H}), 2.63(\mathrm{dq}, J=7.1,11.1 \mathrm{~Hz}, 1 \mathrm{H}), 2.54(\mathrm{dq}, J=7.1,11.1 \mathrm{~Hz}, 1 \mathrm{H}), 1.88$ (brs, $1 \mathrm{H}), 1.40$ (s, 9H), 1.13 (dd, $J=7.1,7.1 \mathrm{~Hz}, 3 \mathrm{H}) ;{ }^{13} \mathrm{C} \mathrm{NMR}\left(100 \mathrm{MHz}, \mathrm{CDCl}_{3}\right) \delta 171.8,141.2,130.8$, $130.4,130.0,125.8,122.6,81.8,65.5,42.1,27.9,15.2$; IR (neat) 3334, 2979, 2931, 1728, 1575, 1474, $1468,1383,1368,1250,1156,1149,843,775,690 \mathrm{~cm}^{-1}$; HRMS (EI): Calcd for $\mathrm{C}_{14} \mathrm{H}_{20} \mathrm{BrNO}_{2}(\mathrm{M})^{+}$ 313.0677 found 313.0685 .

\section{Synthesis of tert-butyl 2-(2-chlorophenyl)-2-(ethylamino)acetate (2m)}

(In the case of 3.0 equiv of Grignard)

Under an argon atmosphere, a solution of $N$-silyl $\alpha$-iminoester $1 \mathrm{~m}(46.8 \mathrm{mg}, 0.15 \mathrm{mmol})$ in DMF $(0.50 \mathrm{~mL})$ was stirred at room temperature for $5 \mathrm{~min}$, and to it was added EtMgBr in THF $(0.51 \mathrm{~mL}$, $0.45 \mathrm{mmol}, 0.88 \mathrm{~N}, 3.0$ equiv) slowly. After the mixture was stirred for $1 \mathrm{~h}$, the reaction was quenched with sat. $\mathrm{NaHCO}_{3}$ aq. $(5.0 \mathrm{~mL})$, and the whole mixture was extracted with ethyl acetate $(10.0 \mathrm{~mL} \times 3)$. The combined extracts were washed with a solution of sat. $\mathrm{NaHCO}_{3}$ aq. $(15 \mathrm{~mL})$, dried over anhydrous $\mathrm{Na}_{2} \mathrm{SO}_{4}$, and concentrated in vacuo. The crude product was purified on silica gel TLC ( $n$-hexane/ethyl acetate $=5 / 1$ ) to give the title compound $2 \mathrm{~m}(28.1 \mathrm{mg}, 69 \%)$.

(In the case of 5.0 equiv of Grignard)

Under an argon atmosphere, a solution of $N$-silyl $\alpha$-iminoester $1 \mathrm{~m}(46.8 \mathrm{mg}, 0.15 \mathrm{mmol})$ in DMF $(0.50 \mathrm{~mL})$ was stirred at room temperature for $5 \mathrm{~min}$, and to it was added EtMgBr in THF $(0.85 \mathrm{~mL}$, $0.75 \mathrm{mmol}, 0.88 \mathrm{~N}, 5.0$ equiv) slowly. After the mixture was stirred for $1 \mathrm{~h}$, the reaction was quenched with sat. $\mathrm{NaHCO}_{3}$ aq. $(5.0 \mathrm{~mL})$, and the whole mixture was extracted with ethyl acetate $(10.0 \mathrm{~mL} \times 3)$. The combined extracts were washed with a solution of sat. $\mathrm{NaHCO}_{3}$ aq. $(15 \mathrm{~mL})$, dried over anhydrous $\mathrm{Na}_{2} \mathrm{SO}_{4}$, and concentrated in vacuo. The crude product was purified on silica gel TLC ( $n$-hexane/ethyl acetate $=5 / 1$ ) to give the title compound $2 \mathrm{~m}(30.5 \mathrm{mg}, 75 \%)$.

tert-Butyl 2-(2-chlorophenyl)-2-(ethylamino)acetate (2m)<smiles>CCNC(C(=O)OC(C)(C)C)c1ccccc1Cl</smiles>

Yield 69\%; Yellow oil; ${ }^{1} \mathrm{H}$ NMR (400 MHz, $\left.\mathrm{CDCl}_{3}\right) \delta$ 7.38-7.36 (m, 2H), 7.26-7.17 (m, 2H), $4.78(\mathrm{~s}, 1 \mathrm{H})$, $2.66(\mathrm{dq}, J=7.1,11.3 \mathrm{~Hz}, 1 \mathrm{H}), 2.55$ (dq, $J=7.1,11.3 \mathrm{~Hz}, 1 \mathrm{H}), 1.96$ (brs, 1H), 1.39 (s, 9H), 1.12 (dd, $J=$ 7.1, $7.1 \mathrm{~Hz}, 3 \mathrm{H}) ;{ }^{13} \mathrm{C}$ NMR $\left(125 \mathrm{MHz}, \mathrm{CDCl}_{3}\right) \delta 171.6,137.0,134.1,129.7,128.7,128.1,127.0,81.6$, 
62.1, 42.1, 27.8, 15.2; IR (neat) 3339, 2973, 1728, 1466, 1382, 1368, 1318, 1246, 1160, 1152, 1039, 951, 846, $755 \mathrm{~cm}^{-1}$; HRMS (EI): Calcd for $\mathrm{C}_{10} \mathrm{H}_{11} \mathrm{CINO}\left(\mathrm{M}-\mathrm{C}_{4} \mathrm{H}_{9} \mathrm{O}\right)^{+} 196.0529$ found 196.0524 .

\section{Synthesis of tert-butyl 2-(4-cyanophenyl)-2-(ethylamino)acetate (2n)}

Under an argon atmosphere, a solution of $N$-silyl $\alpha$-iminoester $1 \mathrm{n}(25.5 \mathrm{mg}, 0.084 \mathrm{mmol})$ in DMF $(0.28 \mathrm{~mL})$ was stirred at room temperature for $5 \mathrm{~min}$, and to it was added $\mathrm{EtMgBr}$ in THF $(0.27 \mathrm{~mL}$, $0.25 \mathrm{mmol}, 0.92 \mathrm{~N}, 3.0$ equiv) slowly. After the mixture was stirred for $1 \mathrm{~h}$, the reaction was quenched with sat. $\mathrm{NaHCO}_{3}$ aq. $(5.0 \mathrm{~mL})$, and the whole mixture was extracted with ethyl acetate $(10.0 \mathrm{~mL} \times 3)$. The combined extracts were washed with a solution of sat. $\mathrm{NaHCO}_{3}$ aq. $(15 \mathrm{~mL})$, dried over anhydrous $\mathrm{Na}_{2} \mathrm{SO}_{4}$, and concentrated in vacuo. The crude product was purified on silica gel TLC ( $n$-hexane/ethyl acetate $=5 / 1$ ) to give the title compound $\mathbf{2 n}(17.9 \mathrm{mg}, 82 \%)$.

tert-Butyl 2-(4-cyanophenyl)-2-(ethylamino)acetate (2n)

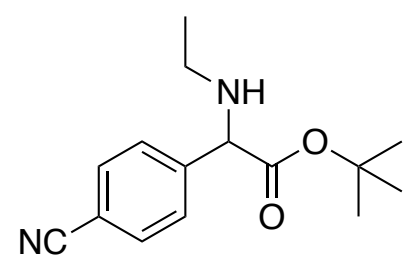

Yield 82\%; Yellow oil; ${ }^{1} \mathrm{H}$ NMR $\left(500 \mathrm{MHz}, \mathrm{CDCl}_{3}\right) \delta$ 7.65-7.63 (m, 2H), 7.52-7.50 (m, 2H), $4.30(\mathrm{~s}, 1 \mathrm{H})$, $2.64(\mathrm{dq}, J=7.2,11.1 \mathrm{~Hz}, 1 \mathrm{H}), 2.53(\mathrm{dq}, J=7.2,11.1 \mathrm{~Hz}, 1 \mathrm{H}), 1.93$ (brs, 1H), $1.39(\mathrm{~s}, 9 \mathrm{H}), 1.13$ (dd, $J=$ 7.2, 7.2 Hz, 3H); ${ }^{13} \mathrm{C} \mathrm{NMR}\left(125 \mathrm{MHz}, \mathrm{CDCl}_{3}\right) \delta 171.2,144.3,132.3,128.1,118.7,111.5,82.3,65.7,42.2$, 27.8, 15.2; IR (neat) 3430, 3061, 2930, 2867, 2240, 1686, 1594, 1492, 1453, 1347, 1278, 1101, 755, $700,587 \mathrm{~cm}^{-1}$; HRMS (EI): Calcd for $\mathrm{C}_{15} \mathrm{H}_{20} \mathrm{~N}_{2} \mathrm{O}_{2}(\mathrm{M})^{+} 260.1525$ found 260.1521 .

\section{Synthesis of tert-butyl 2-(ethylamino)-2-(thiophen-2-yl)acetate (20)}

Under an argon atmosphere, a solution of $N$-silyl $\alpha$-iminoester $10(42.5 \mathrm{mg}, 0.15 \mathrm{mmol})$ in DMF $(0.50 \mathrm{~mL})$ was stirred at room temperature for $5 \mathrm{~min}$, and to it was added $\mathrm{EtMgBr}$ in THF $(0.51 \mathrm{~mL}$, $0.45 \mathrm{mmol}, 0.89 \mathrm{~N}, 3.0$ equiv) slowly. After the mixture was stirred for $3 \mathrm{~h}$, the reaction was quenched with sat. $\mathrm{NaHCO}_{3}$ aq. $(5.0 \mathrm{~mL})$, and the whole mixture was extracted with ethyl acetate $(10.0 \mathrm{~mL} \times 3)$. The combined extracts were washed with a solution of sat. $\mathrm{NaHCO}_{3}$ aq. $(15 \mathrm{~mL})$, dried over anhydrous $\mathrm{Na}_{2} \mathrm{SO}_{4}$, and concentrated in vacuo. The crude product was purified on silica gel TLC ( $n$-hexane/ethyl acetate $=5 / 1$ ) to give the title compound $20(17.8 \mathrm{mg}, 49 \%)$.

tert-Butyl 2-(ethylamino)-2-(thiophen-2-yl)acetate (20)

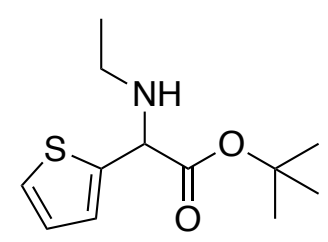

Yield 49\%; Yellow oil; ${ }^{1} \mathrm{H}$ NMR $\left(400 \mathrm{MHz}, \mathrm{CDCl}_{3}\right) \delta 7.22$ (dd, $\left.J=0.9,5.0 \mathrm{~Hz}, 1 \mathrm{H}\right), 7.02-7.00(\mathrm{~m}, 1 \mathrm{H}), 6.95$ $(\mathrm{dd}, J=3.7,5.0 \mathrm{~Hz}, 1 \mathrm{H}), 4.49(\mathrm{~d}, J=0.9 \mathrm{~Hz}, 1 \mathrm{H}), 2.68(\mathrm{dq}, J=7.2,11.3 \mathrm{~Hz}, 1 \mathrm{H}), 2.63(\mathrm{dq}, J=7.2,11.3 \mathrm{~Hz}$, 
1H), 1.91 (brs, 1H), 1.46 (s, 9H), 1.14 (dd, J = 7.2, 7.2 Hz, 3H); $\left.{ }^{13} \mathrm{C} \mathrm{NMR} \mathrm{(100} \mathrm{MHz,} \mathrm{CDCl}_{3}\right) \delta$ 171.4, 142.5, 126.6, 124.9, 124.9, 82.0, 61.7, 42.1, 27.9, 15.2; IR (neat) 3323, 2974, 1730, 1458, 1369, 1309, 1258, $1153,1035,942,797,701 \mathrm{~cm}^{-1}$; HRMS (EI): Calcd for $\mathrm{C}_{12} \mathrm{H}_{19} \mathrm{NO}_{2} \mathrm{~S}(\mathrm{M})^{+} 241.1137$ found 241.1144 .

\section{Synthesis of tert-butyl 2-(ethylamino)-2-(furan-2-yl)acetate (2p)}

(In the case of 3.0 equiv of Grignard)

Under an argon atmosphere, a solution of $N$-silyl $\alpha$-iminoester $1 \mathrm{p}(26.7 \mathrm{mg}, 0.10 \mathrm{mmol})$ in DMF $(0.50 \mathrm{~mL})$ was stirred at room temperature for $5 \mathrm{~min}$, and to it was added $\mathrm{EtMgBr}$ in THF $(0.34 \mathrm{~mL}$, $0.30 \mathrm{mmol}, 0.89 \mathrm{~N}, 3.0$ equiv) slowly. After the mixture was stirred for $3 \mathrm{~h}$, the reaction was quenched with sat. $\mathrm{NaHCO}_{3}$ aq. $(5.0 \mathrm{~mL})$, and the whole mixture was extracted with ethyl acetate $(10.0 \mathrm{~mL} \times 3)$. The combined extracts were washed with a solution of sat. $\mathrm{NaHCO}_{3}$ aq. $(15 \mathrm{~mL})$, dried over anhydrous $\mathrm{Na}_{2} \mathrm{SO}_{4}$, and concentrated in vacuo. The crude product was purified on silica gel TLC ( $n$-hexane/ethyl acetate $=5 / 1$ ) to give the title compound $\mathbf{2 p}(11.0 \mathrm{mg}, 49 \%)$.

(In the case of 5.0 equiv of Grignard)

Under an argon atmosphere, a solution of $N$-silyl $\alpha$-iminoester $1 p(75.0 \mathrm{mg}, 0.28 \mathrm{mmol})$ in DMF $(0.93 \mathrm{~mL})$ was stirred at room temperature for $5 \mathrm{~min}$, and to it was added EtMgBr in THF (1.6 mL, $1.40 \mathrm{mmol}, 0.89 \mathrm{~N}, 5.0$ equiv) slowly. After the mixture was stirred for $3 \mathrm{~h}$, the reaction was quenched with sat. $\mathrm{NaHCO}_{3}$ aq. $(5.0 \mathrm{~mL})$, and the whole mixture was extracted with ethyl acetate $(10.0 \mathrm{~mL} \times 3)$. The combined extracts were washed with a solution of sat. $\mathrm{NaHCO}_{3}$ aq. $(15 \mathrm{~mL})$, dried over anhydrous $\mathrm{Na}_{2} \mathrm{SO}_{4}$, and concentrated in vacuo. The crude product was purified on silica gel TLC ( $n$-hexane/ethyl acetate $=5 / 1$ ) to give the title compound $2 p(36.6 \mathrm{mg}, 58 \%)$.

tert-Butyl 2-(ethylamino)-2-(furan-2-yl)acetate $(2 \mathrm{p})$

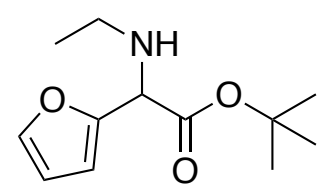

Yield 49\%; Yellow oil; ${ }^{1} \mathrm{H}$ NMR $\left(500 \mathrm{MHz}, \mathrm{CDCl}_{3}\right)$ 8 7.37-7.36 (m, $\left.1 \mathrm{H}\right), 6.34-6.32(\mathrm{~m}, 1 \mathrm{H}), 6.26-6.25(\mathrm{~m}$, $1 \mathrm{H}), 4.36(\mathrm{~s}, 1 \mathrm{H}), 2.64(\mathrm{dq}, J=7.2,11.1 \mathrm{~Hz}, 1 \mathrm{H}), 2.58(\mathrm{dq}, J=7.2,11.1 \mathrm{~Hz}, 1 \mathrm{H}), 1.98(\mathrm{brs}, 1 \mathrm{H}), 1.45(\mathrm{~s}$, $9 \mathrm{H}), 1.13$ (dd, $J=7.2,7.2 \mathrm{~Hz}, 3 \mathrm{H}) ;{ }^{13} \mathrm{C}$ NMR $\left(125 \mathrm{MHz}, \mathrm{CDCl}_{3}\right) \delta 170.3,151.8,142.2,110.2,107.3,81.9$, 60.0, 41.9, 27.9, 15.1; IR (neat) 3333, 2974, 2934, 1734, 1390, 1370, 1222, 1153, 1011, 962, 940, 918, 846, 786, $736 \mathrm{~cm}^{-1}$; HRMS (EI): Calcd for $\mathrm{C}_{8} \mathrm{H}_{10} \mathrm{NO}_{2}(\mathrm{M}-\mathrm{C} 4 \mathrm{H} 9 \mathrm{O})^{+} 152.0712$ found 152.0705.

\section{Synthesis of tert-butyl 2-phenyl-2-(propylamino)acetate (2q)}

(In the case of 3.0 equiv of Grignard)

Under an argon atmosphere, a solution of $N$-silyl $\alpha$-iminoester $1 \mathbf{d}(41.6 \mathrm{mg}, 0.15 \mathrm{mmol})$ in DMF $(0.50 \mathrm{~mL})$ was stirred at room temperature for $5 \mathrm{~min}$, and to it was added ${ }^{\mathrm{n}} \mathrm{PrMgBr}$ in THF $(0.77 \mathrm{~mL}$, $0.45 \mathrm{mmol}, 0.98 \mathrm{~N}, 3.0$ equiv) slowly. After the mixture was stirred for $3 \mathrm{~h}$, the reaction was quenched with sat. $\mathrm{NaHCO}_{3}$ aq. $(5.0 \mathrm{~mL})$, and the whole mixture was extracted with ethyl acetate $(10.0 \mathrm{~mL} \times 3)$. The combined extracts were washed with a solution of sat. $\mathrm{NaHCO}_{3}$ aq. $(15 \mathrm{~mL})$, dried over anhydrous $\mathrm{Na}_{2} \mathrm{SO}_{4}$, and concentrated in vacuo. The crude product was purified on silica gel TLC 
( $n$-hexane/ethyl acetate $=5 / 1$ ) to give the title compound $\mathbf{2 q}(21.0 \mathrm{mg}, 56 \%)$.

(In the case of 5.0 equiv of Grignard)

Under an argon atmosphere, a solution of $N$-silyl $\alpha$-iminoester $1 \mathbf{d}(41.6 \mathrm{mg}, 0.15 \mathrm{mmol})$ in DMF $(0.50 \mathrm{~mL})$ was stirred at room temperature for $5 \mathrm{~min}$, and to it was added ${ }^{n} \mathrm{PrMgBr}$ in THF $(0.77 \mathrm{~mL}$, $0.75 \mathrm{mmol}, 0.98 \mathrm{~N}, 5.0$ equiv) slowly. After the mixture was stirred for $3 \mathrm{~h}$, the reaction was quenched with sat. $\mathrm{NaHCO}_{3}$ aq. $(5.0 \mathrm{~mL})$, and the whole mixture was extracted with ethyl acetate $(10.0 \mathrm{~mL} \times 3)$. The combined extracts were washed with a solution of sat. $\mathrm{NaHCO}_{3}$ aq. $(15 \mathrm{~mL})$, dried over anhydrous $\mathrm{Na}_{2} \mathrm{SO}_{4}$, and concentrated in vacuo. The crude product was purified on silica gel TLC ( $n$-hexane/ethyl acetate $=5 / 1$ ) to give the title compound $\mathbf{2 q}(28.1 \mathrm{mg}, 75 \%)$.

tert-Butyl 2-phenyl-2-(propylamino)acetate (2q)

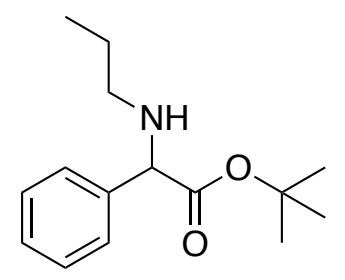

Yield 75\%; Yellow oil; ${ }^{1} \mathrm{H}$ NMR $\left(400 \mathrm{MHz}, \mathrm{CDCl}_{3}\right) \delta$ 7.37-7.25 (m, 5H), $4.23(\mathrm{~s}, 1 \mathrm{H}), 2.55$ (dt, J = 7.3, 11.0 $\mathrm{Hz}, 1 \mathrm{H}), 2.46$ (dt, $J=7.3,11.0 \mathrm{~Hz}, 1 \mathrm{H}), 1.98$ (brs, 1H), 1.53 (ddq, $J=7.3,7.3,7.4 \mathrm{~Hz}, 2 \mathrm{H}), 1.39(\mathrm{~s}, 9 \mathrm{H})$, $0.91(\mathrm{t}, J=7.4 \mathrm{~Hz}, 3 \mathrm{H}) ;{ }^{13} \mathrm{C} \mathrm{NMR}\left(100 \mathrm{MHz}, \mathrm{CDCl}_{3}\right) \delta 172.5,138.9,128.4,127.6,127.2,81.3,66.1,49.7$, 27.9, 23.3, 11.7; IR (neat) 3062, 2967, 2932, 2875, 1732, 1455, 1368, 1251, 1149, 953, 845, 751, 698 $\mathrm{cm}^{-1}$; HRMS (EI): Calcd for $\mathrm{C}_{15} \mathrm{H}_{23} \mathrm{NO}_{2}(\mathrm{M})^{+} 249.1729$ found 249.1722 .

\section{Synthesis of tert-butyl 2-(butylamino)-2-phenylacetate (2s)}

(In the case of 3.0 equiv of Grignard)

Under an argon atmosphere, a solution of $N$-silyl $\alpha$-iminoester $1 \mathbf{d}(42.6 \mathrm{mg}, 0.15 \mathrm{mmol})$ in DMF $(0.50 \mathrm{~mL})$ was stirred at room temperature for $5 \mathrm{~min}$, and to it was added ${ }^{n} \mathrm{PrMgBr}$ in THF $(0.56 \mathrm{~mL}$, $0.45 \mathrm{mmol}, 0.80 \mathrm{~N}, 3.0$ equiv) slowly. After the mixture was stirred for $3 \mathrm{~h}$, the reaction was quenched with sat. $\mathrm{NaHCO}_{3}$ aq. $(5.0 \mathrm{~mL})$, and the whole mixture was extracted with ethyl acetate $(10.0 \mathrm{~mL} \times 3)$. The combined extracts were washed with a solution of sat. $\mathrm{NaHCO}_{3}$ aq. $(15 \mathrm{~mL})$, dried over anhydrous $\mathrm{Na}_{2} \mathrm{SO}_{4}$, and concentrated in vacuo. The crude product was purified on silica gel TLC ( $n$-hexane/ethyl acetate $=5 / 1$ ) to give the title compound 2 s $(34.5 \mathrm{mg}, 87 \%)$.

(In the case of 5.0 equiv of Grignard)

Under an argon atmosphere, a solution of $N$-silyl $\alpha$-iminoester $1 \mathbf{d}(42.6 \mathrm{mg}, 0.15 \mathrm{mmol})$ in DMF $(0.50 \mathrm{~mL})$ was stirred at room temperature for $5 \mathrm{~min}$, and to it was added ${ }^{n} \mathrm{PrMgBr}$ in THF $(0.94 \mathrm{~mL}$, $0.75 \mathrm{mmol}, 0.80 \mathrm{~N}, 5.0$ equiv) slowly. After the mixture was stirred for $3 \mathrm{~h}$, the reaction was quenched with sat. $\mathrm{NaHCO}_{3}$ aq. $(5.0 \mathrm{~mL})$, and the whole mixture was extracted with ethyl acetate $(10.0 \mathrm{~mL} \times 3)$. The combined extracts were washed with a solution of sat. $\mathrm{NaHCO}_{3}$ aq. $(15 \mathrm{~mL})$, dried over anhydrous $\mathrm{Na}_{2} \mathrm{SO}_{4}$, and concentrated in vacuo. The crude product was purified on silica gel TLC ( $n$-hexane/ethyl acetate $=5 / 1$ ) to give the title compound 2 s $(37.8 \mathrm{mg}, 96 \%)$. 


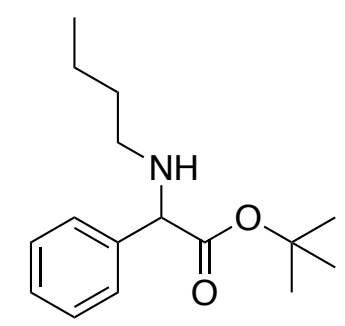

Yellow oil; ${ }^{1} \mathrm{H}$ NMR $\left(400 \mathrm{MHz}, \mathrm{CDCl}_{3}\right) \delta 7.37-7.24(\mathrm{~m}, 5 \mathrm{H}), 4.23(\mathrm{~s}, 1 \mathrm{H}), 2.58(\mathrm{dt}, J=7.2,11.5 \mathrm{~Hz}, 1 \mathrm{H})$, 2.49 (dt, $J=7.2,11.5 \mathrm{~Hz}, 1 \mathrm{H}), 1.97(\mathrm{brs}, 1 \mathrm{H}), 1.55-1.46(\mathrm{~m}, 2 \mathrm{H}), 1.39(\mathrm{~s}, 9 \mathrm{H}), 1.38-1.29(\mathrm{~m}, 2 \mathrm{H}), 0.89$ (t, $J=7.3 \mathrm{~Hz}, 3 \mathrm{H}) ;{ }^{13} \mathrm{C}$ NMR $\left(125 \mathrm{MHz}, \mathrm{CDCl}_{3}\right) \delta 172.5,138.9,128.4,127.6,127.2,81.3,66.2,47.5,32.2$, 27.9, 20.4, 13.9; IR (neat) 3338, 2960, 2871, 1731, 1460, 1368, 1252, 1157, 1149, 845, 741, 702, 694 $\mathrm{cm}^{-1}$; HRMS (EI): Calcd for $\mathrm{C}_{16} \mathrm{H}_{25} \mathrm{NO}_{2}(\mathrm{M})^{+} 263.1885$ found 263.1881 .

\section{Synthesis of ethyl 2-(isobutylamino)-2-phenylacetate (2t)}

Under an argon atmosphere, a solution of $N$-silyl $\alpha$-iminoester 1a (37.4 mg, $0.15 \mathrm{mmol}$ ) in DMF $(0.50 \mathrm{~mL})$ was stirred at room temperature for $5 \mathrm{~min}$, and to it was added ${ }^{~} \mathrm{BuMgBr}$ in $\mathrm{THF}(0.86 \mathrm{~mL}$, $0.75 \mathrm{mmol}, 0.87 \mathrm{~N}, 5.0$ equiv) slowly. After the mixture was stirred for $1 \mathrm{~h}$, the reaction was quenched with sat. $\mathrm{NaHCO}_{3}$ aq. $(5.0 \mathrm{~mL})$, and the whole mixture was extracted with ethyl acetate $(10.0 \mathrm{~mL} \times 3)$. The combined extracts were washed with a solution of sat. $\mathrm{NaHCO}_{3}$ aq. $(15 \mathrm{~mL})$, dried over anhydrous $\mathrm{Na}_{2} \mathrm{SO}_{4}$, and concentrated in vacuo. The crude product was purified on silica gel TLC ( $n$-hexane/ethyl acetate $=5 / 1$ ) to give the title compound $\mathbf{2 t}(28.0 \mathrm{mg}, 79 \%)$.

Ethyl 2-(isobutylamino)-2-phenylacetate (2t)<smiles>CCOC(=O)C(NCC(C)C)c1ccccc1</smiles>

Yield 79\%; Yellow oil; ${ }^{1} \mathrm{H}$ NMR $\left(400 \mathrm{MHz}, \mathrm{CDCl}_{3}\right) \delta$ 7.40-7.26 (m, 5H), $4.32(\mathrm{~s}, 1 \mathrm{H}), 4.19$ (dq, $J=7.1$, $11.0 \mathrm{~Hz}, 1 \mathrm{H}$ ), $4.12(\mathrm{dq}, J=7.1,11.0 \mathrm{~Hz}, 1 \mathrm{H}), 2.40$ (dd, $J=6.6,11.2 \mathrm{~Hz}, 1 \mathrm{H}), 2.30$ (dd, J=6.6, $11.2 \mathrm{~Hz}$, 1H), $1.94(\mathrm{brs}, 1 \mathrm{H}), 1.82-1.69(\mathrm{~m}, 1 \mathrm{H}), 1.20(\mathrm{dd}, J=7.1,7.1 \mathrm{~Hz}, 3 \mathrm{H}), 0.91(\mathrm{~d}, J=6.9 \mathrm{~Hz}, 6 \mathrm{H}) ;{ }^{13} \mathrm{C} \mathrm{NMR}$ $\left(125 \mathrm{MHz}, \mathrm{CDCl}_{3}\right) \delta 173.2,138.5,128.5,127.8,127.3,65.8,61.0,55.7,28.5,20.6,20.6,14.1$; IR (neat) 2962, 2853, 1671, 1545, 1453, 1385, 1266, 1025, 716, $510 \mathrm{~cm}^{-1}$; HRMS (EI): Calcd for $\mathrm{C}_{14} \mathrm{H}_{21} \mathrm{NO}_{2}(\mathrm{M})^{+}$ 235.1572 , found 235.1574 .

\section{Synthesis of tert-butyl 2-(but-3-en-1-ylamino)-2-phenylacetate (2u)}

Under an argon atmosphere, a solution of $N$-silyl $\alpha$-iminoester $1 \mathbf{d}(42.6 \mathrm{mg}, 0.15 \mathrm{mmol})$ in DMF $(0.50 \mathrm{~mL})$ was stirred at room temperature for $5 \mathrm{~min}$, and to it was added ${ }^{~} \mathrm{BuMgBr}$ in THF $(0.64 \mathrm{~mL}$, $0.45 \mathrm{mmol}, 0.70 \mathrm{~N}, 3.0$ equiv) slowly. After the mixture was stirred for $2.5 \mathrm{~h}$, the reaction was quenched with sat. $\mathrm{NaHCO}_{3}$ aq. $(5.0 \mathrm{~mL})$, and the whole mixture was extracted with ethyl acetate 
(10.0 mL x 3). The combined extracts were washed with a solution of sat. $\mathrm{NaHCO}_{3}$ aq. (15 mL), dried over anhydrous $\mathrm{Na}_{2} \mathrm{SO}_{4}$, and concentrated in vacuo. The crude product was purified on silica gel TLC ( $n$-hexane/ethyl acetate $=5 / 1$ ) to give the title compound $2 \mathbf{u}(32.2 \mathrm{mg}, 82 \%)$.

tert-Butyl 2-(but-3-en-1-ylamino)-2-phenylacetate (2u)

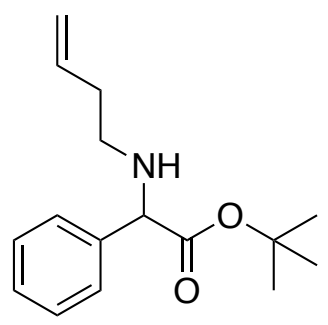

Yield 82\%; Yellow oil; ${ }^{1} \mathrm{H}$ NMR $\left(400 \mathrm{MHz}, \mathrm{CDCl}_{3}\right) \delta 7.36-7.25(\mathrm{~m}, 5 \mathrm{H}), 5.78$ (ddt, $J=6.9,10.3,17.2 \mathrm{~Hz}$, $1 \mathrm{H}), 5.09$ (ddd, $J=1.6,3.4,17.2 \mathrm{~Hz}, 1 \mathrm{H}), 5.05-5.02(\mathrm{~m}, 1 \mathrm{H}), 4.24(\mathrm{~s}, 1 \mathrm{H}), 2.65(\mathrm{dt}, J=6.9,11.2 \mathrm{~Hz}, 1 \mathrm{H})$, $2.57(\mathrm{dt}, J=6.9,11.2 \mathrm{~Hz}, 1 \mathrm{H}), 2.30-2.23(\mathrm{~m}, 2 \mathrm{H}), 1.99$ (brs, $1 \mathrm{H}), 1.39(\mathrm{~s}, 9 \mathrm{H}) ;{ }^{13} \mathrm{C} \mathrm{NMR}\left(125 \mathrm{MHz}, \mathrm{CDCl}_{3}\right)$ $\delta 172.2,138.8136 .2,128.5,127.7,127.2,116.3,81.4,66.1,46.7,34.3,27.9$; IR (neat) 3337, 3071, 2977, 2929, 2843, 1730, 1459, 1384, 1368, 1251, 1150, 914, 846, 747, $697 \mathrm{~cm}^{-1}$; HRMS (El): Calcd for $\mathrm{C}_{12} \mathrm{H}_{14} \mathrm{NO}\left(\mathrm{M}-\mathrm{C}_{4} \mathrm{H}_{9} \mathrm{O}\right)^{+} 188.1075$ found 188.1074 .

\section{Synthesis of tert-Butyl 2-\{[2-(1,3-dioxan-2-yl)ethyl]amino\}-2-phenylacetate (2v)}

Under an argon atmosphere, a solution of $N$-silyl $\alpha$-iminoester $1 \mathbf{d}(42.6 \mathrm{mg}, 0.15 \mathrm{mmol})$ in DMF $(0.50 \mathrm{~mL})$ was stirred at room temperature for $5 \mathrm{~min}$, and to it was added [2-(1,3-dioxan-2-yl)ethyl]magnesium bromide in THF $(0.65 \mathrm{~mL}, 0.45 \mathrm{mmol}, 0.69 \mathrm{~N}, 3.0$ equiv) slowly. After the mixture was stirred for $3 \mathrm{~h}$, the reaction was quenched with sat. $\mathrm{NaHCO}_{3}$ aq. $(5.0 \mathrm{~mL})$, and the whole mixture was extracted with ethyl acetate $(10.0 \mathrm{~mL} \times 3)$. The combined extracts were washed with a solution of sat. $\mathrm{NaHCO}_{3}$ aq. $(15 \mathrm{~mL})$, dried over anhydrous $\mathrm{Na}_{2} \mathrm{SO}_{4}$, and concentrated in vacuo. The crude product was purified on silica gel TLC ( $n$-hexane/ethyl acetate $=5 / 1$ ) to give the title compound $2 \mathbf{v}(35.6 \mathrm{mg}, 74 \%)$.

tert-Butyl 2-\{[2-(1,3-dioxan-2-yl)ethyl]amino\}-2-phenylacetate (2v)

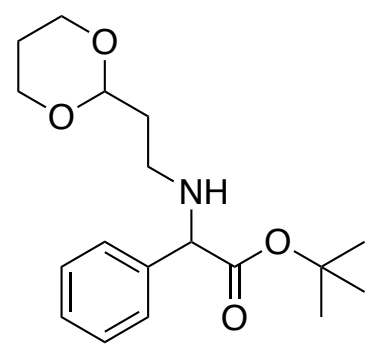

Yield 74\%; Yellow oil; ${ }^{1} \mathrm{H}$ NMR $\left(500 \mathrm{MHz}, \mathrm{CDCl}_{3}\right) \delta 7,37-7.25(\mathrm{~m}, 5 \mathrm{H}), 4.64(\mathrm{t}, J=5.2 \mathrm{~Hz}, 1 \mathrm{H}), 4.22(\mathrm{~s}$, $1 \mathrm{H}), 4.10-4.06(\mathrm{~m}, 2 \mathrm{H}), 3.77-3.72(\mathrm{~m}, 2 \mathrm{H}), 2.69(\mathrm{dt}, J=6.7,11.6 \mathrm{~Hz}, 1 \mathrm{H}), 2.59(\mathrm{dt}, J=6.7,11.6 \mathrm{~Hz}, 1 \mathrm{H})$, 2.12-2.00 (m, 2H), 1.82-1.78 (m, 2H), $1.38(\mathrm{~s}, 9 \mathrm{H}), 1.34-1.30(\mathrm{~m}, 1 \mathrm{H}) ;{ }^{13} \mathrm{C} \mathrm{NMR}\left(100 \mathrm{MHz}, \mathrm{CDCl}_{3}\right) \delta$ 172.2, 138.7, 128.4, 127.7, 127.3, 101.2, 81.4, 66.8, 66.2, 42.6, 35.3, 27.9, 25.8; IR (neat) 3063, 2968, 2851, 1730, 1463, 1368, 1247, 1148, 1143, 1003, 746, $697 \mathrm{~cm}^{-1}$; HRMS(EI): Calcd for $\mathrm{C}_{18} \mathrm{H}_{27} \mathrm{NO}_{4}(\mathrm{M})^{+}$ 


\section{Synthesis of ethyl 2-(tert-butylamino)-2-phenylacetate (2x)}

Under an argon atmosphere, a solution of $N$-silyl $\alpha$-iminoester 1 a $(37.4 \mathrm{mg}, 0.15 \mathrm{mmol}$ ) in DMF $(0.50 \mathrm{~mL})$ was stirred at room temperature for $5 \mathrm{~min}$, and to it was added ${ }^{t} \mathrm{BuMgBr}$ in $\mathrm{THF}(0.44 \mathrm{~mL}$, $0.45 \mathrm{mmol}, 1.03 \mathrm{~N}, 3.0$ equiv) slowly. After the mixture was stirred for $7 \mathrm{~h}$, the reaction was quenched with sat. $\mathrm{NaHCO}_{3}$ aq. $(5.0 \mathrm{~mL})$, and the whole mixture was extracted with ethyl acetate (10.0 $\mathrm{mL} \times$ 3). The combined extracts were washed with a solution of sat. $\mathrm{NaHCO}_{3}$ aq. $(15 \mathrm{~mL})$, dried over anhydrous $\mathrm{Na}_{2} \mathrm{SO}_{4}$, and concentrated in vacuo. The crude product was purified on silica gel TLC ( $n$-hexane/ethyl acetate $=5 / 1$ ) to give the title compound $\mathbf{2 x}(2.60 \mathrm{mg}, 7 \%)$.

Ethyl 2-(tert-butylamino)-2-phenylacetate $(\mathbf{2 x})^{10}$<smiles>CCOC(=O)C(NC(C)(C)C)c1ccccc1</smiles>

Yield 7\%; Yellow oil; ${ }^{1} \mathrm{H}$ NMR $\left(500 \mathrm{MHz}, \mathrm{CDCl}_{3}\right) \delta$ 7.41-7.40 (m, 2H), 7.33-7.24 (m, 3H), $4.45(\mathrm{~s}, 1 \mathrm{H})$, $4.20(\mathrm{dq}, J=7.2,11.0 \mathrm{~Hz}, 1 \mathrm{H}$ ), 4.10 (dq, $J=7.2,11.0 \mathrm{~Hz}, 1 \mathrm{H}), 2.01$ (brs, $1 \mathrm{H}$ ), 1.21 (dd, J = 7.2, 7.2 Hz, $3 \mathrm{H}), 1.11(\mathrm{~s}, 9 \mathrm{H}) ;{ }^{13} \mathrm{C} \mathrm{NMR}\left(125 \mathrm{MHz}, \mathrm{CDCl}_{3}\right) \delta 175.1,140.6,128.6,127.5,127.2,61.2,59.8,51.3,29.4$, 14.0; IR (neat) 3065, 2966, 2905, 2873, 1734, 1454, 1364, 1227, 1202, 1168, 1026, 726, $702 \mathrm{~cm}^{-1}$; HRMS (EI): Calcd for $\mathrm{C}_{12} \mathrm{H}_{16} \mathrm{NO}\left(\mathrm{M}-\mathrm{C}_{2} \mathrm{H}_{5} \mathrm{O}\right)^{+} 190.1232$ found 190.1231 .

\section{7. [Scheme 3] $\mathbf{N}$-Addition of Enolate for $N$-Silyl $\alpha$-Iminoester}

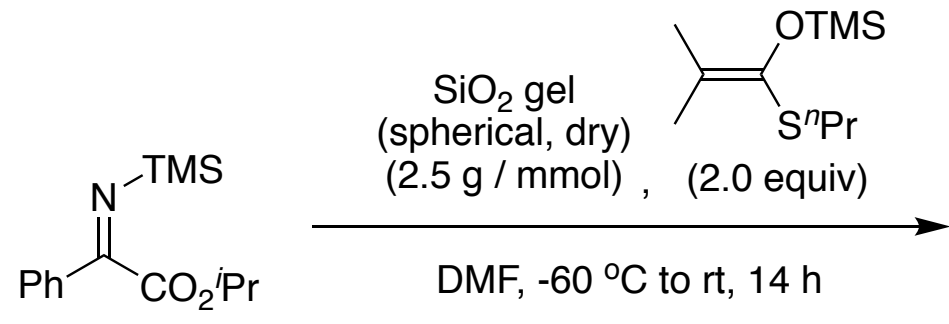

$1 c$<smiles>CCCCCCCC(=O)C(=O)OCC</smiles>

2 y $28 \%$

Under an argon atmosphere, a solution of $\mathrm{N}$-silyl $\alpha$-iminoester $1 \mathrm{c}(39.5 \mathrm{mg}, 0.15 \mathrm{mmol})$ in DMF (0.50 $\mathrm{mL}$ ) was stirred at $-60^{\circ} \mathrm{C}$ for 5 minutes. Dried silica gel $(375 \mathrm{mg})$ and DMF $(1.0 \mathrm{~mL})$ were added to it. A solution of trimethyl\{[2-methyl-1-(propylthio)prop-1-en-1-yl]oxy\}silane $(65.5 \mathrm{mg}, 0.30 \mathrm{mmol}$ ) in DMF $(0.30 \mathrm{~mL})$ was added to the mixture. The mixture was gradually warmed to room temperature during $14 \mathrm{~h}$. Saturated aqueous $\mathrm{NaHCO}_{3}(10 \mathrm{~mL})$ was added to quench the reaction. The mixture was filtered with suction through a Celite pad and washed with ethyl acetate. The mixture was extracted with ethyl acetate $(3 \times 5.0 \mathrm{~mL})$. The combine extracts were dried over $\mathrm{Na}_{2} \mathrm{SO}_{4}$ and concentrated in vacuo to give a crude product. Purification on silica gel TLC ( $n$-Hexane : ethyl acetate $=5: 1$ as an eluent) gave isopropyl 2-\{[2-methyl-1-oxo-1-(propylthio)propan-2-yl]amino\}-2-phenylacetate 2y (14.2 mg, 28\%). 
Isopropyl 2-\{[2-methyl-1-oxo-1-(propylthio)propan-2-yl]amino\}-2-phenylacetate (2y)<smiles>CCCSC(=O)C(C)(C)NC(C(=O)OC(C)C)c1ccccc1</smiles>

Yield 28\%; Yellow oil; ${ }^{1} \mathrm{H}$ NMR $\left(400 \mathrm{MHz}, \mathrm{CDCl}_{3}\right) \delta$ 7.64-7.61 (m, 2H), 7.36-7.28 (m, 3H), 5.16 (qq, $J=$ $6.2,6.2 \mathrm{~Hz}, 1 \mathrm{H}), 4.44(\mathrm{~s}, 1 \mathrm{H}), 2.85(\mathrm{t}, J=7.3 \mathrm{~Hz}, 2 \mathrm{H}), 1.61(\mathrm{tq}, J=7.3,7.3 \mathrm{~Hz}, 2 \mathrm{H}), 1.41(\mathrm{~s}, 3 \mathrm{H}), 1.33(\mathrm{~d}, J$ $=6.2 \mathrm{~Hz}, 3 \mathrm{H}), 1.30(\mathrm{~d}, J=6.2 \mathrm{~Hz}, 3 \mathrm{H}), 1.20(\mathrm{~s}, 3 \mathrm{H}), 0.98(\mathrm{t}, J=7.3 \mathrm{~Hz}, 3 \mathrm{H}) ;{ }^{13} \mathrm{C} \mathrm{NMR}\left(100 \mathrm{MHz}, \mathrm{CDCl}_{3}\right) \delta$ 208.0, 173.4, 137.8, 127.9, 127.5, 127.4, 81.7, 70.2, 57.3, 30.8, 23.7, 22.7, 22.2, 21.7, 21.5, 13.4; IR (neat) 2976, 2931, 2873, 1722, 1675, 1387, 1254, 1106, 962, 787, 757, $705 \mathrm{~cm}^{-1}$; HRMS (EI) : Calcd for $\mathrm{C}_{18} \mathrm{H}_{27} \mathrm{NO}_{3} \mathrm{~S}(\mathrm{M})^{+} 337.1712$, found 337.1726 .

\section{Proposed Reaction Mechanism in the Presence of Silica Gel}

path (a)
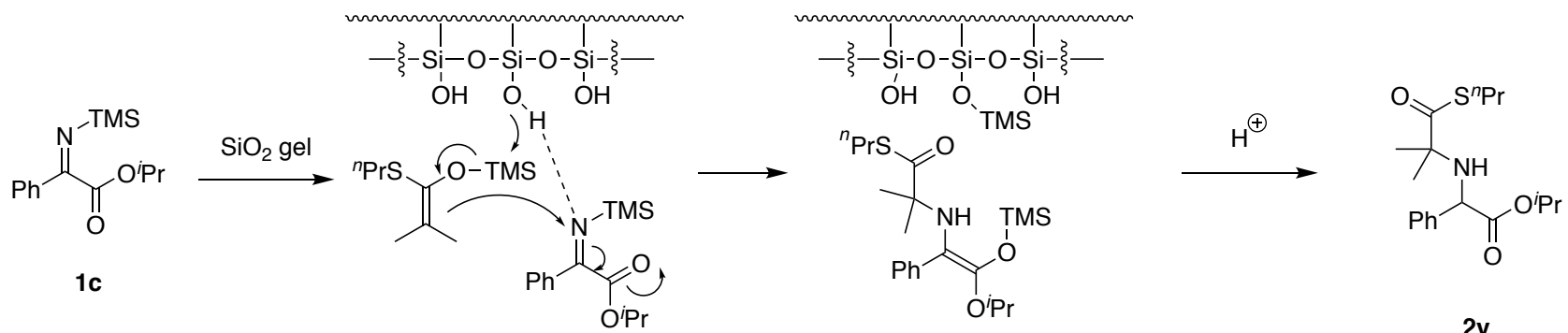

$2 y$

path (b)<smiles>CCCOC(=O)/C(=N\N(C)S(=O)(=O)O)c1ccccc1</smiles>

$1 c$

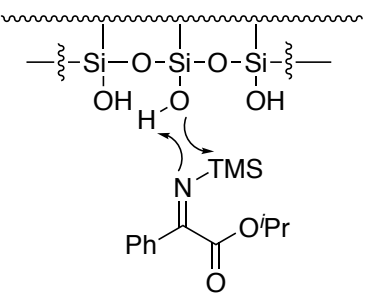

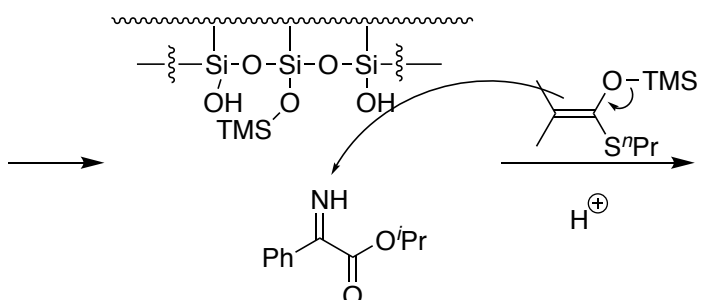

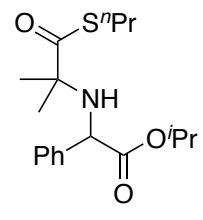

$2 y$ 


\section{9. [Scheme 4 \& Table S4] Optimization of Tandem N-Alkylation/intramolecular Cyclization}

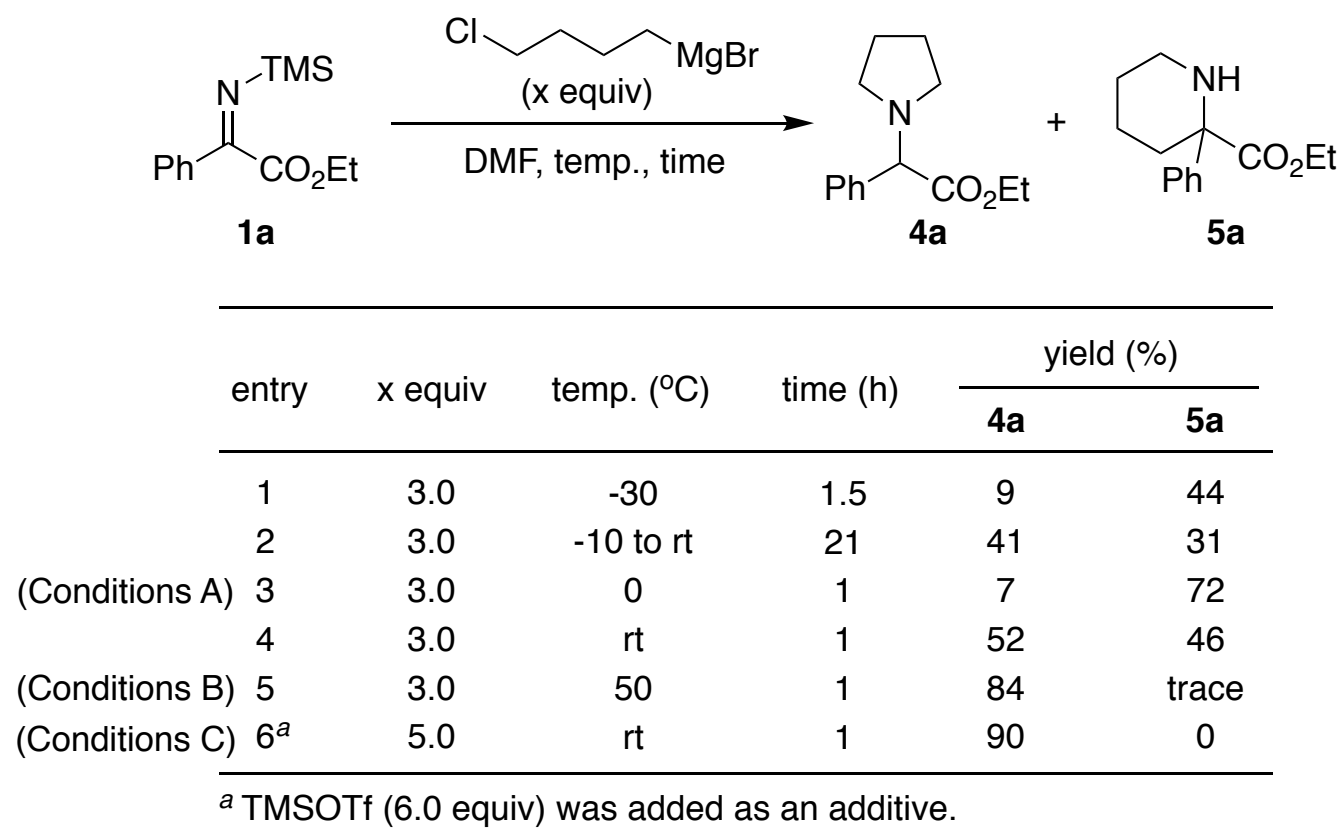

(Table S4, entry 1)

Under an argon atmosphere, a solution of $N$-silyl $\alpha$-iminoester 1 a $(37.4 \mathrm{mg}, 0.15 \mathrm{mmol}$ ) in DMF $\left(0.50 \mathrm{~mL}\right.$ ) was stirred at $-30{ }^{\circ} \mathrm{C}$ for $5 \mathrm{~min}$, and to it was added (4-chlorobutyl)magnesium bromide in THF $(0.56 \mathrm{~mL}, 0.45 \mathrm{mmol}, 0.80 \mathrm{~N}, 3.0$ equiv) slowly. After the mixture was stirred for $1.5 \mathrm{~h}$, the reaction was quenched with sat. $\mathrm{NaHCO}_{3}$ aq. $(5.0 \mathrm{~mL}$ ), and the whole mixture was extracted with ethyl acetate $(10.0 \mathrm{~mL} \times 3)$. The combined extracts were washed with a solution of sat. $\mathrm{NaHCO}_{3}$ aq. $(15 \mathrm{~mL})$, dried over anhydrous $\mathrm{Na}_{2} \mathrm{SO}_{4}$, and concentrated in vacuo. The crude product was purified on silica gel TLC $\left(\mathrm{CH}_{2} \mathrm{Cl}_{2} / \mathrm{MeOH}=10 / 1\right)$ to give ethyl 2-phenyl-2-(pyrrolidin-1-yl)acetate 4a (3.20 mg, 9\%) and 5 a (15.4 mg, 44\%).

Ethyl 2-phenyl-2-(pyrrolidin-1-yl)acetate (4a) ${ }^{11}$<smiles>CCOC(=O)C(c1ccccc1)N1CCCC1</smiles>

Yellow oil; ${ }^{1} \mathrm{H}$ NMR $\left(500 \mathrm{MHz}, \mathrm{CDCl}_{3}\right) \delta$ 7.48-7.47 (d, $\left.J=7.3 \mathrm{~Hz}, 2 \mathrm{H}\right), 7.35-7.23(\mathrm{~m}, 3 \mathrm{H}), 4.22-4.09(\mathrm{~m}$, $2 \mathrm{H}), 3.90(\mathrm{~s}, 1 \mathrm{H}), 2.61-2.52(\mathrm{~m}, 2 \mathrm{H}), 2.47-2.38(\mathrm{~m}, 2 \mathrm{H}), 1.84-1.74(\mathrm{~m}, 4 \mathrm{H}), 1.20(\mathrm{t}, J=7.0 \mathrm{~Hz}, 3 \mathrm{H}) ;{ }^{13} \mathrm{C}$ NMR $\left(125 \mathrm{MHz}_{2} \mathrm{CDCl}_{3}\right) \delta 171.7,137.4,128.4,128.4,128.2,74.1,60.9,52.5,23.3,14.1$; IR (neat) 3065, 2971, 2875, 1745, 1454, 1371, 1257, 1165, 1028, 907, 734, $705 \mathrm{~cm}^{-1}$; HRMS (EI): Calcd for $\mathrm{C}_{14} \mathrm{H}_{19} \mathrm{NO}_{2}$ $(\mathrm{M})^{+} 233.1416$ found 233.1405 .

Ethyl 2-phenylpiperidine-2-carboxylate (5a) 


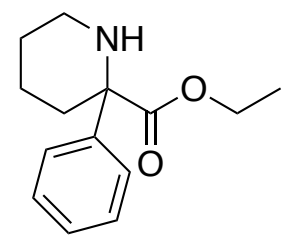

Yellow oil; ${ }^{1} \mathrm{H}$ NMR (500 MHz, $\left.\mathrm{CDCl}_{3}\right) \delta$ 7.50-7.49 (m, 2H), 7.34-7.24 (m, 3H), 4.25-4.16 (m, 2H), 3.05-3.01 (m, 1H), 2.79-2.74 (m, 1H), $2.57(\mathrm{brs}, 1 \mathrm{H}), 2.46-2.43(\mathrm{~m}, 1 \mathrm{H}), 1.74-1.48(\mathrm{~m}, 5 \mathrm{H}), 1.24(\mathrm{dd}, J=$ 7.0, 7.0 Hz, 3H); ${ }^{13} \mathrm{C} \mathrm{NMR}\left(125 \mathrm{MHz}, \mathrm{CDCl}_{3}\right) \delta 174.6,143.3,128.4,127.3,125.1,65.7,61.0,43.8,35.2$, 25.0, 22.5, 14.2; IR (neat) 3328, 3062, 2933, 2861, 1713, 1447, 1348, 1217, 1120, 1026, 790, 754, 701 $\mathrm{cm}^{-1}$; HRMS (EI): Calcd for $\mathrm{C}_{14} \mathrm{H}_{19} \mathrm{NO}_{2}(\mathrm{M})^{+} 233.1416$ found 233.1420 .

\section{(Table S4, entry 2)}

Under an argon atmosphere, a solution of $\mathrm{N}$-silyl $\alpha$-iminoester 1a $(37.4 \mathrm{mg}, 0.15 \mathrm{mmol}$ ) in DMF $\left(0.50 \mathrm{~mL}\right.$ ) was stirred at $-10{ }^{\circ} \mathrm{C}$ for $5 \mathrm{~min}$, and to it was added (4-chlorobutyl)magnesium bromide in THF ( $0.56 \mathrm{~mL}, 0.45 \mathrm{mmol}, 0.80 \mathrm{~N}, 3.0$ equiv) slowly. After the mixture was stirred at $-10^{\circ} \mathrm{C}$ to $\mathrm{rt}$ for 21 $h$, the reaction was quenched with sat. $\mathrm{NaHCO}_{3}$ aq. $(5.0 \mathrm{~mL})$, and the whole mixture was extracted with ethyl acetate $(10.0 \mathrm{~mL} \times 3)$. The combined extracts were washed with a solution of sat. $\mathrm{NaHCO}_{3}$ aq. (15 mL), dried over anhydrous $\mathrm{Na}_{2} \mathrm{SO}_{4}$, and concentrated in vacuo. The crude product was purified on silica gel TLC $\left(\mathrm{CH}_{2} \mathrm{Cl}_{2} / \mathrm{MeOH}=10 / 1\right)$ to give ethyl 2-phenyl-2-(pyrrolidin-1-yl)acetate $4 a$ (14.4 mg, 41\%) and 5a (11.0 mg, 31\%).

(Table S4, entry 3) (Conditions A)

Under an argon atmosphere, a solution of $N$-silyl $\alpha$-iminoester 1 a $(37.4 \mathrm{mg}, 0.15 \mathrm{mmol}$ ) in DMF $\left(0.50 \mathrm{~mL}\right.$ ) was stirred at $0{ }^{\circ} \mathrm{C}$ for $5 \mathrm{~min}$, and to it was added (4-chlorobutyl)magnesium bromide in THF $(0.56 \mathrm{~mL}, 0.45 \mathrm{mmol}, 0.80 \mathrm{~N}, 3.0$ equiv) slowly. After the mixture was stirred for $1 \mathrm{~h}$, the reaction was quenched with sat. $\mathrm{NaHCO}_{3}$ aq. $(5.0 \mathrm{~mL})$, and the whole mixture was extracted with ethyl acetate $(10.0 \mathrm{~mL} \times 3)$. The combined extracts were washed with a solution of sat. $\mathrm{NaHCO}_{3}$ aq. $(15 \mathrm{~mL})$, dried over anhydrous $\mathrm{Na}_{2} \mathrm{SO}_{4}$, and concentrated in vacuo. The crude product was purified on silica gel TLC $\left(\mathrm{CH}_{2} \mathrm{Cl}_{2} / \mathrm{MeOH}=10 / 1\right)$ to give ethyl 2-phenyl-2-(pyrrolidin-1-yl)acetate 4a $(2.60 \mathrm{mg}, 7 \%)$ and $5 \mathrm{a}$ (25.2 mg, 72\%).

(Table S4, entry 4)

Under an argon atmosphere, a solution of $N$-silyl $\alpha$-iminoester 1 a $(37.4 \mathrm{mg}, 0.15 \mathrm{mmol}$ ) in DMF $(0.50 \mathrm{~mL})$ was stirred at room temperature for $5 \mathrm{~min}$, and to it was added (4-chlorobutyl)magnesium bromide in THF ( $0.56 \mathrm{~mL}, 0.45 \mathrm{mmol}, 0.80 \mathrm{~N}, 3.0$ equiv) slowly. After the mixture was stirred for $1 \mathrm{~h}$, the reaction was quenched with sat. $\mathrm{NaHCO}_{3}$ aq. $(5.0 \mathrm{~mL})$, and the whole mixture was extracted with ethyl acetate $(10.0 \mathrm{~mL} \times 3)$. The combined extracts were washed with a solution of sat. $\mathrm{NaHCO}_{3}$ aq. $(15 \mathrm{~mL})$, dried over anhydrous $\mathrm{Na}_{2} \mathrm{SO}_{4}$, and concentrated in vacuo. The crude product was purified on silica gel TLC $\left(\mathrm{CH}_{2} \mathrm{Cl}_{2} / \mathrm{MeOH}=10 / 1\right)$ to give ethyl 2-phenyl-2-(pyrrolidin-1-yl)acetate 4a (18.1 mg, $52 \%)$ and $5 \mathrm{a}(16.1 \mathrm{mg}, 46 \%)$.

(Table S4, entry 5) (Conditions B)

Under an argon atmosphere, a solution of $N$-silyl $\alpha$-iminoester 1 a $(37.4 \mathrm{mg}, 0.15 \mathrm{mmol})$ in DMF $\left(0.50 \mathrm{~mL}\right.$ ) was stirred at $50{ }^{\circ} \mathrm{C}$ for $5 \mathrm{~min}$, and to it was added (4-chlorobutyl)magnesium bromide in 
THF ( $0.56 \mathrm{~mL}, 0.45 \mathrm{mmol}, 0.80 \mathrm{~N}, 3.0$ equiv) slowly. After the mixture was stirred for $1 \mathrm{~h}$, the reaction was quenched with sat. $\mathrm{NaHCO}_{3}$ aq. $(5.0 \mathrm{~mL})$, and the whole mixture was extracted with ethyl acetate (10.0 $\mathrm{mL} \times 3$ ). The combined extracts were washed with a solution of sat. $\mathrm{NaHCO}_{3}$ aq. $(15 \mathrm{~mL})$, dried over anhydrous $\mathrm{Na}_{2} \mathrm{SO}_{4}$, and concentrated in vacuo. The crude product was purified on silica gel TLC $\left(\mathrm{CH}_{2} \mathrm{Cl}_{2} / \mathrm{MeOH}=10 / 1\right)$ to give ethyl 2-phenyl-2-(pyrrolidin-1-yl)acetate 4a (29.3 mg, 84\%).

(Table S4, entry 6) (Conditions $C$ )

Under an argon atmosphere, a solution of $N$-silyl $\alpha$-iminoester $1 \mathrm{a}$ ( $37.4 \mathrm{mg}, 0.15 \mathrm{mmol}$ ) and TMSOTf $(0.16 \mathrm{~mL}, 0.9 \mathrm{mmol}, 6.0$ equiv) in $\mathrm{DMF}(0.50 \mathrm{~mL})$ was stirred at room temperature for $5 \mathrm{~min}$, and to it was added (4-chlorobutyl)magnesium bromide in THF ( $1.32 \mathrm{~mL}, 0.75 \mathrm{mmol}, 0.57 \mathrm{~N}, 5.0$ equiv) slowly. After the mixture was stirred for $1 \mathrm{~h}$, the reaction was quenched with sat. $\mathrm{NaHCO}_{3}$ aq. $(5.0 \mathrm{~mL})$, and the whole mixture was extracted with ethyl acetate $(10.0 \mathrm{~mL} \times 3)$. The combined extracts were washed with a solution of sat. $\mathrm{NaHCO}_{3}$ aq. $(15 \mathrm{~mL})$, dried over anhydrous $\mathrm{Na}_{2} \mathrm{SO}_{4}$, and concentrated in vacuo. The crude product was purified on silica gel TLC ( $n$-hexane/AcOEt $=5 / 1)$ to give ethyl 2-phenyl-2-(pyrrolidin-1-yl)acetate $4 a$ (31.4 mg, 90\%). 


\section{0. [Scheme 5] Scope of Substrates for Tandem N-Alkylation/intramolecular Cyclization}
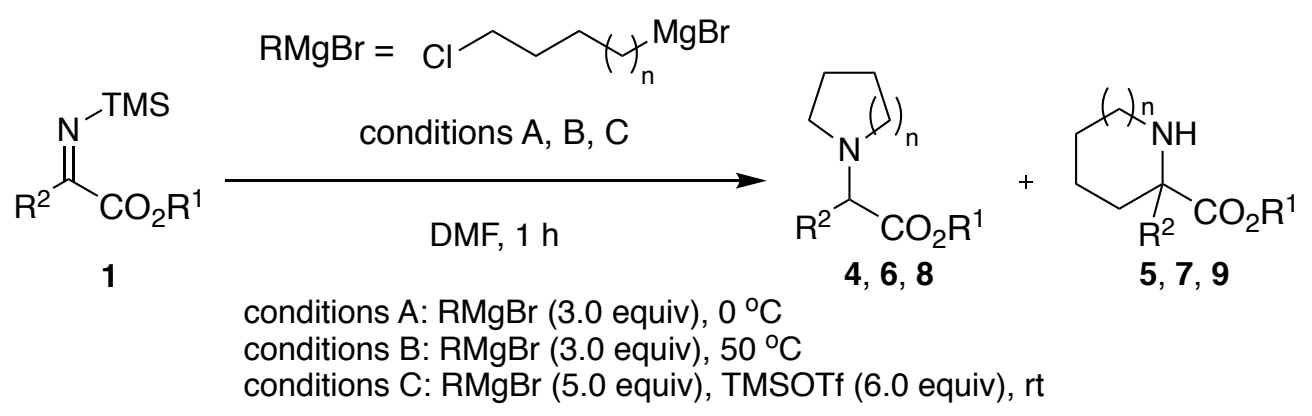

$5,7,9$

conditions $\mathrm{B}: \mathrm{RMgBr}$ ( 3.0 equiv), $50^{\circ} \mathrm{C}$

conditions $\mathrm{C}$ : $\mathrm{RMgBr}$ (5.0 equiv), TMSOTf (6.0 equiv), rt

\section{Syntheses of ethyl 2-phenyl-2-(pyrrolidin-1-yl)acetate (4a) and ethyl 2-phenylpiperidine-2-carboxylate (5a)}

(Conditions A): Same as in entry 3, Table S4.

(Conditions B): Same as in entry 5, Table S4.

(Conditions C): Same as in entry 6, Table S4.

(Conditions $A$, on a $1 \mathrm{mmol}$ scale reaction)

Under an argon atmosphere, a solution of $N$-silyl $\alpha$-iminoester 1a ( $249 \mathrm{mg}, 1.00 \mathrm{mmol}$ ) in DMF (3.3 $\mathrm{m}$ ) was stirred at $0{ }^{\circ} \mathrm{C}$ for $5 \mathrm{~min}$, and to it was added (4-chlorobutyl)magnesium bromide in THF (6.1 $\mathrm{mL}, 3.00 \mathrm{mmol}, 0.49 \mathrm{~N}, 3.0$ equiv) slowly. After the mixture was stirred for $1 \mathrm{~h}$, the reaction was quenched with sat. $\mathrm{NaHCO}_{3}$ aq. $(5.0 \mathrm{~mL})$, and the whole mixture was extracted with ethyl acetate $(10.0 \mathrm{~mL} \times 3)$. The combined extracts were washed with a solution of sat. $\mathrm{NaHCO}_{3}$ aq. $(15 \mathrm{~mL})$, dried over anhydrous $\mathrm{Na}_{2} \mathrm{SO}_{4}$, and concentrated in vacuo. The crude product was purified by column chromatography on silica gel $\left(\mathrm{CH}_{2} \mathrm{Cl}_{2} / \mathrm{AcOEt}=23 / 2\right)$ to give ethyl 2-phenyl-2-(pyrrolidin-1-yl)acetate 5a (198 mg, 85\%).

(Conditions $C$, on a $1 \mathrm{mmol}$ scale reaction)

Under an argon atmosphere, a solution of $N$-silyl $\alpha$-iminoester $1 \mathrm{a}$ ( $249 \mathrm{mg}, 1.00 \mathrm{mmol}$ ) and TMSOTf (1.1 mL, $6.00 \mathrm{mmol}, 6.0$ equiv) in DMF (3.3 mL) was stirred at room temperature for $5 \mathrm{~min}$, and to it was added (4-chlorobutyl)magnesium bromide in THF (10.2 mL, $5.00 \mathrm{mmol}, 0.49 \mathrm{~N}, 5.0$ equiv) slowly. After the mixture was stirred for $1 \mathrm{~h}$, the reaction was quenched with sat. $\mathrm{NaHCO}_{3}$ aq. $(5.0 \mathrm{~mL})$, and the whole mixture was extracted with ethyl acetate $(10.0 \mathrm{~mL} \times 3)$. The combined extracts were washed with a solution of sat. $\mathrm{NaHCO}_{3}$ aq. $(15 \mathrm{~mL})$, dried over anhydrous $\mathrm{Na}_{2} \mathrm{SO}_{4}$, and concentrated in vacuo. The crude product was purified on silica gel TLC $\left(\mathrm{CH}_{2} \mathrm{Cl}_{2} / \mathrm{AcOEt}=21 / 1\right)$ to give ethyl 2-phenyl-2-(pyrrolidin-1-yl)acetate 4a (227 mg, 97\%).

Syntheses of ethyl 2-(4-chlorophenyl)-2-(pyrrolidin-1-yl)acetate (4b) and ethyl 2-(4-chlorophenyl)piperidine-2-carboxylate (5b)

(Conditions A)

Under an argon atmosphere, a solution of $N$-silyl $\alpha$-iminoester $1 \mathrm{q}(42.6 \mathrm{mg}, 0.15 \mathrm{mmol})$ in DMF $\left(0.50 \mathrm{~mL}\right.$ ) was stirred at $0{ }^{\circ} \mathrm{C}$ for $5 \mathrm{~min}$, and to it was added (4-chlorobutyl)magnesium bromide in THF $(0.51 \mathrm{~mL}, 0.45 \mathrm{mmol}, 0.88 \mathrm{~N}, 3.0$ equiv) slowly. After the mixture was stirred for $1 \mathrm{~h}$, the reaction was 
quenched with sat. $\mathrm{NaHCO}_{3}$ aq. $(5.0 \mathrm{~mL}$ ), and the whole mixture was extracted with ethyl acetate $(10.0 \mathrm{~mL} \times 3)$. The combined extracts were washed with a solution of sat. $\mathrm{NaHCO}_{3}$ aq. $(15 \mathrm{~mL})$, dried over anhydrous $\mathrm{Na}_{2} \mathrm{SO}_{4}$, and concentrated in vacuo. The crude product was purified on silica gel TLC ( $n$-hexane/AcOEt $=6 / 1$ ) to give ethyl 2-(4-chlorophenyl)-2-(pyrrolidin-1-yl)acetate $\mathbf{4 b}$ (1.50 mg, 4\%) and 5 b (21.4 mg, 53\%).

\section{(Conditions $B$ )}

Under an argon atmosphere, a solution of $N$-silyl $\alpha$-iminoester $1 \mathbf{q}(42.6 \mathrm{mg}, 0.15 \mathrm{mmol})$ in DMF $(0.50 \mathrm{~mL})$ was stirred at $50^{\circ} \mathrm{C}$ for $5 \mathrm{~min}$, and to it was added (4-chlorobutyl)magnesium bromide in THF ( $0.45 \mathrm{~mL}, 0.45 \mathrm{mmol}, 1.01 \mathrm{~N}, 3.0$ equiv) slowly. After the mixture was stirred for $1 \mathrm{~h}$, the reaction was quenched with sat. $\mathrm{NaHCO}_{3}$ aq. $(5.0 \mathrm{~mL})$, and the whole mixture was extracted with ethyl acetate (10.0 $\mathrm{mL} \times 3$ ). The combined extracts were washed with a solution of sat. $\mathrm{NaHCO}_{3}$ aq. $(15 \mathrm{~mL})$, dried over anhydrous $\mathrm{Na}_{2} \mathrm{SO}_{4}$, and concentrated in vacuo. The crude product was purified on silica gel TLC $\left(\mathrm{CH}_{2} \mathrm{Cl}_{2} / \mathrm{MeOH}=10 / 1\right)$ to give ethyl 2-(4-chlorophenyl)-2-(pyrrolidin-1-yl)acetate 4b (16.1 mg, 40\%).

\section{(Conditions $C$ )}

Under an argon atmosphere, a solution of $N$-silyl $\alpha$-iminoester $1 \mathbf{q}(42.6 \mathrm{mg}, 0.15 \mathrm{mmol}$ ) and TMSOTf ( $0.16 \mathrm{~mL}, 0.9 \mathrm{mmol}, 6.0$ equiv) in $\mathrm{DMF}(0.50 \mathrm{~mL})$ was stirred at room temperature for $5 \mathrm{~min}$, and to it was added (4-chlorobutyl)magnesium bromide in THF ( $1.53 \mathrm{~mL}, 0.75 \mathrm{mmol}, 0.49 \mathrm{~N}, 5.0$ equiv) slowly. After the mixture was stirred for $1 \mathrm{~h}$, the reaction was quenched with sat. $\mathrm{NaHCO}_{3}$ aq. $(5.0 \mathrm{~mL})$, and the whole mixture was extracted with ethyl acetate $(10.0 \mathrm{~mL} \times 3)$. The combined extracts were washed with a solution of sat. $\mathrm{NaHCO}_{3}$ aq. $(15 \mathrm{~mL})$, dried over anhydrous $\mathrm{Na}_{2} \mathrm{SO}_{4}$, and concentrated in vacuo. The crude product was purified on silica gel TLC ( $n$-hexane/AcOEt $=5 / 1)$ to give ethyl 2-(4-chlorophenyl)-2-(pyrrolidin-1-yl)acetate 4b (22.6 mg, 56\%).

\section{Ethyl 2-(4-chlorophenyl)-2-(pyrrolidin-1-yl)acetate (4b)}

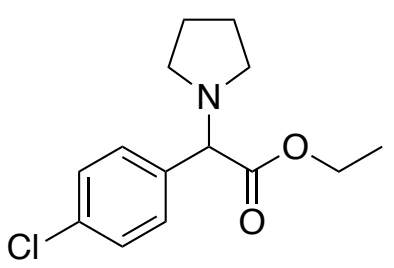

Yellow oil; ${ }^{1} \mathrm{H}$ NMR $\left(500 \mathrm{MHz}, \mathrm{CDCl}_{3}\right) \delta$ 7.43-7.42 (m, 2H), 7.32-7.30 (m, 2H), 4.19 (dq, J= 7.0, $10.7 \mathrm{~Hz}$, $1 \mathrm{H}), 4.12(\mathrm{dq}, J=7.0,10.7 \mathrm{~Hz}, 1 \mathrm{H}), 3.87(\mathrm{~s}, 1 \mathrm{H}), 2.58-2.52(\mathrm{~m}, 2 \mathrm{H}), 2.46-2.40(\mathrm{~m}, 2 \mathrm{H}), 1.85-1.77(\mathrm{~m}$, $4 \mathrm{H}), 1.20$ (dd, $J=7.0,7.0 \mathrm{~Hz}, 3 \mathrm{H}) ;{ }^{13} \mathrm{C}$ NMR $\left(125 \mathrm{MHz}, \mathrm{CDCl}_{3}\right) \delta 171.4,136.0,134.0,129.7,128.7,73.3$, 61.1, 52.5, 23.3, 14.1; IR (neat) 2971, 2876, 1744, 1490, 1370, 1172, 1092, 1015, 904, 833, $759 \mathrm{~cm}^{-1}$; HRMS (EI): Calcd for $\mathrm{C}_{14} \mathrm{H}_{18} \mathrm{ClNO}_{2}(\mathrm{M})^{+} 267.1026$ found 267.1018 .

Ethyl 2-(4-chlorophenyl)piperidine-2-carboxylate (5b) 


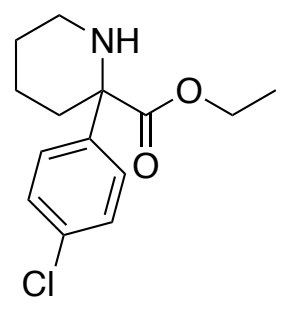

Yellow oil; ${ }^{1} \mathrm{H}$ NMR (400 MHz, $\left.\mathrm{CDCl}_{3}\right) \delta$ 7.45-7.42 (m, 2H), 7.31-7.27 (m, 2H), 4.26-4.14 (m, 2H), 3.03-2.99 (m, $1 \mathrm{H}), 2.78-2.71(\mathrm{~m}, 1 \mathrm{H}), 2.42-2.37(\mathrm{~m}, 1 \mathrm{H}), 2.18$ (brs, $1 \mathrm{H}), 1.73-1.46(\mathrm{~m}, 5 \mathrm{H}), 1.24(\mathrm{dd}, J=$ 7.1, $7.1 \mathrm{~Hz}, 3 \mathrm{H}) ;{ }^{13} \mathrm{C} \mathrm{NMR}\left(100 \mathrm{MHz}, \mathrm{CDCl}_{3}\right) \delta 174.3,142.0,133.2,128.5,126.7,65.4,61.2,43.7,35.3$, 25.0, 22.4, 14.2; IR (neat) 3338, 3062, 2935, 2859, 1726, 1486, 1220, 1119, 1100, 1021, 830, 790, 753 $\mathrm{cm}^{-1}$; HRMS (EI): Calcd for $\mathrm{C}_{14} \mathrm{H}_{18} \mathrm{ClNO}_{2}(\mathrm{M})^{+} 267.1026$ found 267.1023 .

\section{Syntheses of ethyl 2-(4-methoxyphenyl)-2-(pyrrolidin-1-yl)acetate (4c) and ethyl 2-(4-methoxyphenyl)piperidine-2-carboxylate (5c)}

(Conditions A)

Under an argon atmosphere, a solution of $N$-silyl $\alpha$-iminoester $1 \mathbf{r}$ ( $41.9 \mathrm{mg}, 0.15 \mathrm{mmol})$ in DMF (0.50 $\mathrm{mL}$ ) was stirred at $0{ }^{\circ} \mathrm{C}$ for $5 \mathrm{~min}$, and to it was added (4-chlorobutyl)magnesium bromide in THF $(0.51$ $\mathrm{mL}, 0.45 \mathrm{mmol}, 0.88 \mathrm{~N}, 3.0$ equiv) slowly. After the mixture was stirred for $1 \mathrm{~h}$, the reaction was quenched with sat. $\mathrm{NaHCO}_{3}$ aq. $(5.0 \mathrm{~mL})$, and the whole mixture was extracted with ethyl acetate $(10.0 \mathrm{~mL} \times 3)$. The combined extracts were washed with a solution of sat. $\mathrm{NaHCO}_{3}$ aq. $(15 \mathrm{~mL})$, dried over anhydrous $\mathrm{Na}_{2} \mathrm{SO}_{4}$, and concentrated in vacuo. The crude product was purified on silica gel TLC ( $n$-hexane/AcOEt $=6 / 1)$ to give ethyl 2-(4-methoxyphenyl)piperidine-2-carboxylate $5 \mathrm{c}(22.5 \mathrm{mg}$, $57 \%)$.

\section{(Conditions B)}

Under an argon atmosphere, a solution of $N$-silyl $\alpha$-iminoester $1 \mathbf{r}$ ( $41.9 \mathrm{mg}, 0.15 \mathrm{mmol})$ in DMF (0.50 $\mathrm{mL}$ ) was stirred at $50{ }^{\circ} \mathrm{C}$ for $5 \mathrm{~min}$, and to it was added (4-chlorobutyl)magnesium bromide in THF $(0.53 \mathrm{~mL}, 0.45 \mathrm{mmol}, 0.85 \mathrm{~N}, 3.0$ equiv) slowly. After the mixture was stirred for $1 \mathrm{~h}$, the reaction was quenched with sat. $\mathrm{NaHCO}_{3}$ aq. $(5.0 \mathrm{~mL})$, and the whole mixture was extracted with ethyl acetate $(10.0 \mathrm{~mL} \times 3)$. The combined extracts were washed with a solution of sat. $\mathrm{NaHCO}_{3}$ aq. $(15 \mathrm{~mL})$, dried over anhydrous $\mathrm{Na}_{2} \mathrm{SO}_{4}$, and concentrated in vacuo. The crude product was purified on silica gel TLC $\left(\mathrm{CH}_{2} \mathrm{Cl}_{2} / \mathrm{MeOH}=10 / 1\right)$ to give ethyl 2-(4-methoxyphenyl)-2-(pyrrolidin-1-yl)acetate 4c (23.2 mg, $59 \%)$ and $5 \mathrm{c}(1.1 \mathrm{mg}, 3 \%)$.

\section{(Conditions C)}

Under an argon atmosphere, a solution of $N$-silyl $\alpha$-iminoester $1 \mathbf{r}(41.9 \mathrm{mg}, 0.15 \mathrm{mmol}$ ) and TMSOTf $(0.16 \mathrm{~mL}, 0.9 \mathrm{mmol}, 6.0$ equiv) in $\mathrm{DMF}(0.50 \mathrm{~mL})$ was stirred at room temperature for $5 \mathrm{~min}$, and to it was added (4-chlorobutyl)magnesium bromide in THF $(1.53 \mathrm{~mL}, 0.75 \mathrm{mmol}, 0.49 \mathrm{~N}, 5.0$ equiv) slowly. After the mixture was stirred for $1 \mathrm{~h}$, the reaction was quenched with sat. $\mathrm{NaHCO}_{3}$ aq. $(5.0 \mathrm{~mL})$, and the whole mixture was extracted with ethyl acetate $(10.0 \mathrm{~mL} \times 3)$. The combined extracts were washed with a solution of sat. $\mathrm{NaHCO}_{3}$ aq. $(15 \mathrm{~mL})$, dried over anhydrous $\mathrm{Na}_{2} \mathrm{SO}_{4}$, and concentrated in vacuo. The crude product was purified on silica gel TLC ( $n$-hexane/AcOEt $=5 / 1)$ to give ethyl 2-(4-methoxyphenyl)-2-(pyrrolidin-1-yl)acetate 4c (21.4 mg, 54\%). 
Ethyl 2-(4-methoxyphenyl)-2-(pyrrolidin-1-yl)acetate (4c)

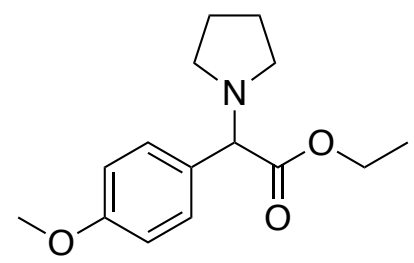

Yellow oil; ${ }^{1} \mathrm{H}$ NMR $\left(400 \mathrm{MHz}, \mathrm{CDCl}_{3}\right) \delta$ 7.41-7.37 (m, $\left.2 \mathrm{H}\right), 6.88-6.84(\mathrm{~m}, 2 \mathrm{H}), 4.19(\mathrm{dq}, J=7.1,10.8 \mathrm{~Hz}$, $1 \mathrm{H}), 4.12(\mathrm{dq}, J=7.1,10.8 \mathrm{~Hz}, 1 \mathrm{H}), 3.84(\mathrm{~s}, 1 \mathrm{H}), 3.80(\mathrm{~s}, 3 \mathrm{H}), 2.59-2.51(\mathrm{~m}, 2 \mathrm{H}), 2.48-2.39(\mathrm{~m}, 2 \mathrm{H})$, 1.85-1.75 (m, 4H), $1.20(\mathrm{dd}, J=7.1,7.1 \mathrm{~Hz}, 3 \mathrm{H}) ;{ }^{13} \mathrm{C} \mathrm{NMR}\left(100 \mathrm{MHz}, \mathrm{CDCl}_{3}\right) \delta 172.0,159.5,129.7$, $129.5,113.8,73.3,60.8,55.2,52.5,23.3,14.1$; IR (neat) 2970, 2877, 1736, 1608, 1511, 1460, 1300, $1248,1171,1031,836,796,667 \mathrm{~cm}^{-1}$; HRMS (EI): Calcd for $\mathrm{C}_{15} \mathrm{H}_{21} \mathrm{NO}_{3}(\mathrm{M})^{+} 263.1521$ found 263.1533.

Ethyl 2-(4-methoxyphenyl)piperidine-2-carboxylate (5c)

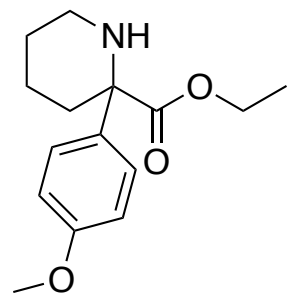

Yellow oil; ${ }^{1} \mathrm{H}$ NMR $\left(500 \mathrm{MHz}, \mathrm{CDCl}_{3}\right)$ $\delta$ 7.43-7.39 (m, 2H), 6.88-6.85 (m, 2H), 4.24-4.15 (m, 2H), $3.79(\mathrm{~s}$, $3 \mathrm{H}), 3.20-2.90(\mathrm{~m}, 2 \mathrm{H}), 2.80-2.75(\mathrm{~m}, 1 \mathrm{H}), 2.44-2.41(\mathrm{~m}, 1 \mathrm{H}), 1.74-1.47(\mathrm{~m}, 5 \mathrm{H}), 1.24(\mathrm{dd}, J=7.0,7.0$ $\mathrm{Hz}, 3 \mathrm{H}) ;{ }^{13} \mathrm{C}$ NMR $\left(125 \mathrm{MHz}, \mathrm{CDCl}_{3}\right) \delta 174.5,158.7,135.1,126.3,113.7,65.1,61.1,55.2,43.7,34.9$, 24.9, 22.4, 14.2; IR (neat) 3340, 2935, 2836, 1725, 1609, 1512, 1458, 1300, 1249, 1218, 1179, 1122, 1032, $831 \mathrm{~cm}^{-1}$; HRMS (EI): Calcd for $\mathrm{C}_{15} \mathrm{H}_{21} \mathrm{NO}_{3}(\mathrm{M})^{+} 263.1521$ found 263.1517.

\section{Syntheses of ethyl 2-(naphthalen-1-yl)-2-(pyrrolidin-1-yl)acetate (4d)}

\section{(Conditions A)}

Under an argon atmosphere, a solution of $N$-silyl $\alpha$-iminoester $1 \mathrm{~s}$ ( $44.9 \mathrm{mg}, 0.15 \mathrm{mmol})$ in DMF (0.50 $\mathrm{mL}$ ) was stirred at $0{ }^{\circ} \mathrm{C}$ for $5 \mathrm{~min}$, and to it was added (4-chlorobutyl)magnesium bromide in THF (0.56 $\mathrm{mL}, 0.45 \mathrm{mmol}, 0.80 \mathrm{~N}, 3.0$ equiv) slowly. After the mixture was stirred for $1 \mathrm{~h}$, the reaction was quenched with sat. $\mathrm{NaHCO}_{3}$ aq. $(5.0 \mathrm{~mL})$, and the whole mixture was extracted with ethyl acetate $(10.0 \mathrm{~mL} \times 3)$. The combined extracts were washed with a solution of sat. $\mathrm{NaHCO}_{3}$ aq. $(15 \mathrm{~mL})$, dried over anhydrous $\mathrm{Na}_{2} \mathrm{SO}_{4}$, and concentrated in vacuo. The crude product was purified on silica gel TLC $\left(\mathrm{CH}_{2} \mathrm{Cl}_{2} / \mathrm{AcOEt}=21 / 2\right)$ to give ethyl 2-(naphthalen-1-yl)-2-(pyrrolidin-1-yl)acetate $4 \mathbf{d}$ (15.1 mg, 35\%).

\section{(Conditions $B$ )}

Under an argon atmosphere, a solution of $N$-silyl $\alpha$-iminoester $1 \mathrm{~s}$ ( $44.9 \mathrm{mg}, 0.15 \mathrm{mmol}$ ) in DMF (0.50 $\mathrm{mL}$ ) was stirred at $50{ }^{\circ} \mathrm{C}$ for $5 \mathrm{~min}$, and to it was added (4-chlorobutyl)magnesium bromide in THF $(0.56 \mathrm{~mL}, 0.45 \mathrm{mmol}, 0.80 \mathrm{~N}, 3.0$ equiv) slowly. After the mixture was stirred for $1 \mathrm{~h}$, the reaction was quenched with sat. $\mathrm{NaHCO}_{3}$ aq. $(5.0 \mathrm{~mL})$, and the whole mixture was extracted with ethyl acetate $(10.0 \mathrm{~mL} \times 3)$. The combined extracts were washed with a solution of sat. $\mathrm{NaHCO}_{3}$ aq. $(15 \mathrm{~mL})$, dried 
over anhydrous $\mathrm{Na}_{2} \mathrm{SO}_{4}$, and concentrated in vacuo. The crude product was purified on silica gel TLC $\left(\mathrm{CH}_{2} \mathrm{Cl}_{2} / \mathrm{AcOEt}=21 / 2\right)$ to give ethyl 2-(naphthalen-1-yl)-2-(pyrrolidin-1-yl)acetate $4 \mathbf{d}$ (22.9 mg, 54\%). (Conditions $\mathrm{C}$ )

Under an argon atmosphere, a solution of $N$-silyl $\alpha$-iminoester $1 \mathrm{~s}$ ( $44.9 \mathrm{mg}, 0.15 \mathrm{mmol}$ ) and TMSOTf $(0.16 \mathrm{~mL}, 0.9 \mathrm{mmol}, 6.0$ equiv) in $\mathrm{DMF}(0.50 \mathrm{~mL})$ was stirred at room temperature for $5 \mathrm{~min}$, and to it was added (4-chlorobutyl)magnesium bromide in THF $(1.53 \mathrm{~mL}, 0.75 \mathrm{mmol}, 0.49 \mathrm{~N}, 5.0$ equiv) slowly. After the mixture was stirred for $1 \mathrm{~h}$, the reaction was quenched with sat. $\mathrm{NaHCO}_{3}$ aq. $(5.0 \mathrm{~mL})$, and the whole mixture was extracted with ethyl acetate $(10.0 \mathrm{~mL} \times 3)$. The combined extracts were washed with a solution of sat. $\mathrm{NaHCO}_{3}$ aq. $\left(15 \mathrm{~mL}\right.$ ), dried over anhydrous $\mathrm{Na}_{2} \mathrm{SO}_{4}$, and concentrated in vacuo. The crude product was purified on silica gel TLC ( $n$-hexane/AcOEt $=5 / 1)$ to give ethyl 2-(naphthalen-1-yl)-2-(pyrrolidin-1-yl)acetate 4d (13.9 mg, 33\%).

Ethyl 2-(naphthalen-1-yl)-2-(pyrrolidin-1-yl)acetate (4d)

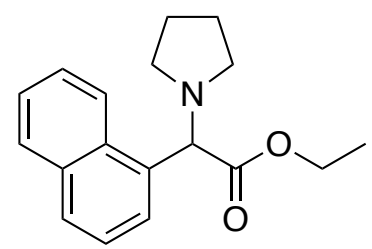

Yellow oil; ${ }^{1} \mathrm{H}$ NMR $\left(400 \mathrm{MHz}, \mathrm{CDCl}_{3}\right) \delta 8.52-8.50(\mathrm{~m}, 1 \mathrm{H}), 7.86-7.76(\mathrm{~m}, 3 \mathrm{H}), 7.56-7.44(\mathrm{~m}, 3 \mathrm{H}), 4.74(\mathrm{~s}$, $1 \mathrm{H}), 4.15(\mathrm{dq}, J=7.1,10.6 \mathrm{~Hz}, 1 \mathrm{H}), 4.07(\mathrm{dq}, J=7.1,10.6 \mathrm{~Hz}, 1 \mathrm{H}), 2.69-2.60(\mathrm{~m}, 2 \mathrm{H}), 2.57-2.49(\mathrm{~m}, 2 \mathrm{H})$, 1.84-1.76 (m, 4H), $1.13(\mathrm{dd}, J=7.1,7.1 \mathrm{~Hz}, 3 \mathrm{H}) ;{ }^{13} \mathrm{C} \mathrm{NMR}\left(100 \mathrm{MHz}, \mathrm{CDCl}_{3}\right) \delta 171.8,133.9,133.5$, 131.6, 128.6, 128.6, 126.9, 126.1, 125.6, 125.4, 124.1, 69.9, 60.8, 52.4, 23.5, 14.1; IR (neat) 3048, 2967, 2873, 1741, 1674, 1510, 1370, 1181, 1160, 1093, 1027, 907, $778 \mathrm{~cm}^{-1}$; HRMS (EI): Calcd for $\mathrm{C}_{18} \mathrm{H}_{21} \mathrm{NO}_{2}(\mathrm{M})^{+} 283.1572$ found 283.1568 .

\section{Syntheses of methyl 2-phenyl-2-(pyrrolidin-1-yl)acetate (4e) and methyl 2-phenylpiperidine-2-carboxylate (5e)}

\section{(Conditions A)}

Under an argon atmosphere, a solution of $N$-silyl $\alpha$-iminoester $\mathbf{1 b}$ (35.3 mg, $0.15 \mathrm{mmol}$ ) in DMF (0.50 $\mathrm{mL}$ ) was stirred at $0{ }^{\circ} \mathrm{C}$ for $5 \mathrm{~min}$, and to it was added (4-chlorobutyl)magnesium bromide in THF $(0.45$ $\mathrm{mL}, 0.45 \mathrm{mmol}, 1.01 \mathrm{~N}, 3.0$ equiv) slowly. After the mixture was stirred for $1 \mathrm{~h}$, the reaction was quenched with sat. $\mathrm{NaHCO}_{3}$ aq. $(5.0 \mathrm{~mL})$, and the whole mixture was extracted with ethyl acetate $(10.0 \mathrm{~mL} \times 3)$. The combined extracts were washed with a solution of sat. $\mathrm{NaHCO}_{3}$ aq. $(15 \mathrm{~mL})$, dried over anhydrous $\mathrm{Na}_{2} \mathrm{SO}_{4}$, and concentrated in vacuo. The crude product was purified on silica gel TLC ( $n$-hexane/AcOEt $=6 / 1$ ) to give methyl 2-phenyl-2-(pyrrolidin-1-yl)acetate 4 e $(1.50 \mathrm{mg}, 5 \%)$ and 5 e (25.4 mg, 77\%).

\section{(Conditions B)}

Under an argon atmosphere, a solution of $N$-silyl $\alpha$-iminoester $\mathbf{1 b}(35.3 \mathrm{mg}, 0.15 \mathrm{mmol}$ ) in DMF $\left(0.50 \mathrm{~mL}\right.$ ) was stirred at $50^{\circ} \mathrm{C}$ for $5 \mathrm{~min}$, and to it was added (4-chlorobutyl)magnesium bromide in THF ( $0.48 \mathrm{~mL}, 0.45 \mathrm{mmol}, 0.93 \mathrm{~N}, 3.0$ equiv) slowly. After the mixture was stirred for $1 \mathrm{~h}$, the reaction was quenched with sat. $\mathrm{NaHCO}_{3}$ aq. $(5.0 \mathrm{~mL})$, and the whole mixture was extracted with ethyl acetate 
(10.0 $\mathrm{mL}$ x 3). The combined extracts were washed with a solution of sat. $\mathrm{NaHCO}_{3}$ aq. $(15 \mathrm{~mL})$, dried over anhydrous $\mathrm{Na}_{2} \mathrm{SO}_{4}$, and concentrated in vacuo. The crude product was purified on silica gel TLC $\left(\mathrm{CH}_{2} \mathrm{Cl}_{2} / \mathrm{AcOEt}=21 / 1\right)$ to give methyl 2-phenyl-2-(pyrrolidin-1-yl)acetate 4 e $(17.3 \mathrm{mg}, 53 \%)$ and $5 e$ (3.1 mg, 9\%).

\section{(Conditions C)}

Under an argon atmosphere, a solution of $\mathrm{N}$-silyl $\alpha$-iminoester $\mathbf{1 b}$ ( $35.3 \mathrm{mg}, 0.15 \mathrm{mmol}$ ) and TMSOTf $(0.16 \mathrm{~mL}, 0.9 \mathrm{mmol}, 6.0$ equiv) in $\mathrm{DMF}(0.50 \mathrm{~mL})$ was stirred at room temperature for $5 \mathrm{~min}$, and to it was added (4-chlorobutyl)magnesium bromide in THF ( $1.53 \mathrm{~mL}, 0.75 \mathrm{mmol}, 0.49 \mathrm{~N}, 5.0$ equiv) slowly. After the mixture was stirred for $1 \mathrm{~h}$, the reaction was quenched with sat. $\mathrm{NaHCO}_{3}$ aq. $(5.0 \mathrm{~mL})$, and the whole mixture was extracted with ethyl acetate $(10.0 \mathrm{~mL} \times 3)$. The combined extracts were washed with a solution of sat. $\mathrm{NaHCO}_{3}$ aq. $(15 \mathrm{~mL})$, dried over anhydrous $\mathrm{Na}_{2} \mathrm{SO}_{4}$, and concentrated in vacuo. The crude product was purified on silica gel TLC ( $n$-hexane/AcOEt $=5 / 1)$ to give methyl 2-phenyl-2-(pyrrolidin-1-yl)acetate 4e (6.9 mg, 21\%).

Methyl 2-phenyl-2-(pyrrolidin-1-yl)acetate $(\mathbf{4 e})^{12}$

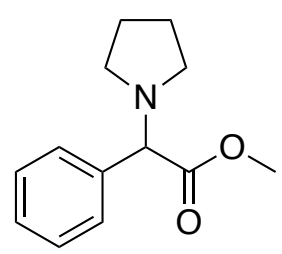

Yellow oil; IR (neat) 3069, 2959, 2873, 1749, 1444, 1202, 1162, 1009, 790, 735, $698 \mathrm{~cm}^{-1}$; HRMS (EI): Calcd for $\mathrm{C}_{12} \mathrm{H}_{14} \mathrm{NO}\left(\mathrm{M}-\mathrm{CH}_{3} \mathrm{O}\right)^{+} 188.1075$ found 188.1070 .

Methyl 2-phenylpiperidine-2-carboxylate $(5 e)^{13}$<smiles>COC(=O)C1(c2ccccc2)CCCCN1</smiles>

Yellow oil; ${ }^{1} \mathrm{H}$ NMR (400 MHz, $\left.\mathrm{CDCl}_{3}\right)$ 8 7.49-7.46 (m, 2H), 7.35-7.23 (m, 3H), 3.72 (s, 3H), 3.05-3.01 (m, $1 \mathrm{H}), 2.78-2.71(\mathrm{~m}, 1 \mathrm{H}), 2.55-2.20(\mathrm{~m}, 2 \mathrm{H}), 1.82-1.46(\mathrm{~m}, 5 \mathrm{H}) ;{ }^{13} \mathrm{C} \mathrm{NMR}\left(100 \mathrm{MHz}, \mathrm{CDCl}_{3}\right) \delta$ 175.2, 143.3, $128.5,127.4,125.1,65.9,52.2,43.9,35.2,25.1,22.5$; IR (neat) 3342, 3061, 2939, 2857, 1730, 1443, 1353, 1223, 1126, 997, 756, $699 \mathrm{~cm}^{-1}$; HRMS (EI): Calcd for $\mathrm{C}_{12} \mathrm{H}_{14} \mathrm{NO}\left(\mathrm{M}-\mathrm{CH}_{3} \mathrm{O}\right)^{+} 188.1075$ found 188.1071.

\section{Syntheses of isopropyl 2-phenyl-2-(pyrrolidin-1-yl)acetate (4f) and isopropyl \\ 2-phenylpiperidine-2-carboxylate (5f)}

\section{(Conditions A)}

Under an argon atmosphere, a solution of $N$-silyl $\alpha$-iminoester $1 \mathrm{c}(39.5 \mathrm{mg}, 0.15 \mathrm{mmol})$ in DMF (0.50 $\mathrm{mL}$ ) was stirred at $0{ }^{\circ} \mathrm{C}$ for $5 \mathrm{~min}$, and to it was added (4-chlorobutyl)magnesium bromide in THF $(0.55$ $\mathrm{mL}, 0.45 \mathrm{mmol}, 0.82 \mathrm{~N}, 3.0$ equiv) slowly. After the mixture was stirred for $1 \mathrm{~h}$, the reaction was quenched with sat. $\mathrm{NaHCO}_{3}$ aq. $(5.0 \mathrm{~mL})$, and the whole mixture was extracted with ethyl acetate 
(10.0 $\mathrm{mL}$ x 3). The combined extracts were washed with a solution of sat. $\mathrm{NaHCO}_{3}$ aq. $(15 \mathrm{~mL})$, dried over anhydrous $\mathrm{Na}_{2} \mathrm{SO}_{4}$, and concentrated in vacuo. The crude product was purified by silica gel TLC $\left(\mathrm{CH}_{2} \mathrm{Cl}_{2} / \mathrm{AcOEt}=21 / 2\right)$ to give isopropyl 2-phenyl-2-(pyrrolidin-1-yl)acetate $\mathbf{4 f}(4.90 \mathrm{mg}, 13 \%)$ and $\mathbf{5 e}$ (27.0 mg, 73\%).

\section{(Conditions B)}

Under an argon atmosphere, a solution of $\mathrm{N}$-silyl $\alpha$-iminoester $1 \mathrm{c}$ (39.5 mg, $0.15 \mathrm{mmol}$ ) in DMF (0.50 $\mathrm{mL}$ ) was stirred at $50{ }^{\circ} \mathrm{C}$ for $5 \mathrm{~min}$, and to it was added (4-chlorobutyl)magnesium bromide in THF ( $0.45 \mathrm{~mL}, 0.45 \mathrm{mmol}, 1.01 \mathrm{~N}, 3.0$ equiv) slowly. After the mixture was stirred for $1 \mathrm{~h}$, the reaction was quenched with sat. $\mathrm{NaHCO}_{3}$ aq. $(5.0 \mathrm{~mL})$, and the whole mixture was extracted with ethyl acetate $(10.0 \mathrm{~mL} \times 3)$. The combined extracts were washed with a solution of sat. $\mathrm{NaHCO}_{3}$ aq. $(15 \mathrm{~mL})$, dried over anhydrous $\mathrm{Na}_{2} \mathrm{SO}_{4}$, and concentrated in vacuo. The crude product was purified on silica gel TLC $\left(\mathrm{CH}_{2} \mathrm{Cl}_{2} / \mathrm{AcOEt}=21 / 2\right)$ to give isopropyl 2-phenyl-2-(pyrrolidin-1-yl)acetate $\mathbf{4 f}(21.4 \mathrm{mg}, 58 \%)$ and $\mathbf{5 f}$ (1.40 mg, 4\%).

\section{(Conditions $C$ )}

Under an argon atmosphere, a solution of $N$-silyl $\alpha$-iminoester $1 \mathrm{c}(39.5 \mathrm{mg}, 0.15 \mathrm{mmol}$ ) and TMSOTf ( $0.16 \mathrm{~mL}, 0.9 \mathrm{mmol}, 6.0$ equiv) in $\mathrm{DMF}(0.50 \mathrm{~mL})$ was stirred at room temperature for $5 \mathrm{~min}$, and to it was added (4-chlorobutyl)magnesium bromide in THF ( $1.53 \mathrm{~mL}, 0.75 \mathrm{mmol}, 0.49 \mathrm{~N}, 5.0$ equiv) slowly. After the mixture was stirred for $1 \mathrm{~h}$, the reaction was quenched with sat. $\mathrm{NaHCO}_{3}$ aq. $(5.0 \mathrm{~mL})$, and the whole mixture was extracted with ethyl acetate $(10.0 \mathrm{~mL} \times 3)$. The combined extracts were washed with a solution of sat. $\mathrm{NaHCO}_{3}$ aq. $(15 \mathrm{~mL})$, dried over anhydrous $\mathrm{Na}_{2} \mathrm{SO}_{4}$, and concentrated in vacuo. The crude product was purified on silica gel TLC ( $n$-hexane/AcOEt $=5 / 1$ ) to give isopropyl 2-phenyl-2-(pyrrolidin-1-yl)acetate $\mathbf{4 f}$ (31.6 mg, 85\%).

Isopropyl 2-phenyl-2-(pyrrolidin-1-yl)acetate (4f)

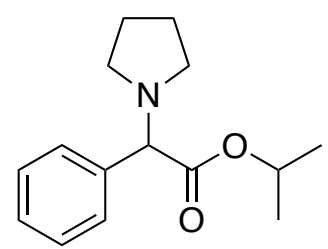

Yellow oil; ${ }^{1} \mathrm{H}$ NMR (500 MHz, $\left.\mathrm{CDCl}_{3}\right)$ $\delta$ 7.49-7.47 (m, 2H), 7.34-7.28 (m, 3H), 5.03 (qq, J=6.2, $6.2 \mathrm{~Hz}$, $1 \mathrm{H}), 3.86(\mathrm{~s}, 1 \mathrm{H}), 2.64-2.52(\mathrm{~m}, 2 \mathrm{H}), 2.51-2.39(\mathrm{~m}, 2 \mathrm{H}), 1.86-1.76(\mathrm{~m}, 4 \mathrm{H}), 1.23(\mathrm{~d}, J=6.2 \mathrm{~Hz}, 3 \mathrm{H}), 1.12$ $(\mathrm{d}, J=6.2 \mathrm{~Hz}, 3 \mathrm{H}) ;{ }^{13} \mathrm{C} \mathrm{NMR}\left(125 \mathrm{MHz}, \mathrm{CDCl}_{3}\right) \delta 171.3,137.6,128.4,128.3,128.0,74.2,68.2,52.5$, 23.3, 21.7, 21.4; IR (neat) 2974, 2931, 2877, 1733, 1457, 1376, 1262, 1174, 1105, 785, 754, $705 \mathrm{~cm}^{-1}$; HRMS (EI): Calcd for $\mathrm{C}_{15} \mathrm{H}_{21} \mathrm{NO}_{2}(\mathrm{M})^{+} 247.1572$ found 247.1581 .

Isopropyl 2-phenylpiperidine-2-carboxylate (5f)

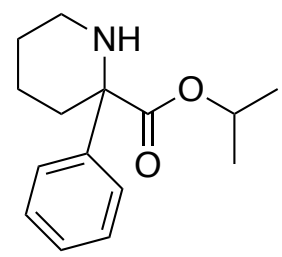


Yellow oil; ${ }^{1} \mathrm{H}$ NMR (500 MHz, $\left.\mathrm{CDCl}_{3}\right) \delta$ 7.50-7.49 (m, 2H), 7.34-7.24 (m, 3H), 5.09 (qq, J = 6.2, $6.2 \mathrm{~Hz}$, $1 \mathrm{H}), 3.30-2.90(\mathrm{~m}, 2 \mathrm{H}), 2.81-2.75(\mathrm{~m}, 1 \mathrm{H}), 2.46-2.43(\mathrm{~m}, 1 \mathrm{H}), 1.74-1.48(\mathrm{~m}, 5 \mathrm{H}), 1.23(\mathrm{~d}, J=6.2 \mathrm{~Hz}, 3 \mathrm{H})$, $1.20(\mathrm{~d}, J=6.2 \mathrm{~Hz}, 3 \mathrm{H}) ;{ }^{13} \mathrm{C} \mathrm{NMR}\left(125 \mathrm{MHz}, \mathrm{CDCl}_{3}\right) \delta 174.0,143.5,128.3,127.2,125.0,68.5,65.6,43.8$, 35.2, 25.0, 22.5, 21.7; IR (neat) 3330, 3060, 2978, 2935, 1723, 1453, 1374, 1221, 1105, 971, 918, 841, 764, $699 \mathrm{~cm}^{-1}$; HRMS (EI): Calcd for $\mathrm{C}_{15} \mathrm{H}_{21} \mathrm{NO}_{2}(\mathrm{M})^{+} 247.1572$ found 247.1562 .

\section{Syntheses of tert-butyl 2-phenyl-2-(pyrrolidin-1-yl)acetate (4g) and tert-butyl 2-phenylpiperidine-2-carboxylate (5g)}

\section{(Conditions A)}

Under an argon atmosphere, a solution of $N$-silyl $\alpha$-iminoester $1 \mathbf{d}(41.6 \mathrm{mg}, 0.15 \mathrm{mmol})$ in DMF $\left(0.50 \mathrm{~mL}\right.$ ) was stirred at $0^{\circ} \mathrm{C}$ for $5 \mathrm{~min}$, and to it was added (4-chlorobutyl)magnesium bromide in THF ( $0.55 \mathrm{~mL}, 0.45 \mathrm{mmol}, 0.82 \mathrm{~N}, 3.0$ equiv) slowly. After the mixture was stirred for $1 \mathrm{~h}$, the reaction was quenched with sat. $\mathrm{NaHCO}_{3}$ aq. $(5.0 \mathrm{~mL})$, and the whole mixture was extracted with ethyl acetate $(10.0 \mathrm{~mL} \times 3)$. The combined extracts were washed with a solution of sat. $\mathrm{NaHCO}_{3}$ aq. $(15 \mathrm{~mL})$, dried over anhydrous $\mathrm{Na}_{2} \mathrm{SO}_{4}$, and concentrated in vacuo. The crude product was purified on silica gel TLC $\left(\mathrm{CH}_{2} \mathrm{Cl}_{2} /\right.$ AcOEt $\left.=21 / 2\right)$ to give tert-butyl 2-phenylpiperidine-2-carboxylate $5 \mathrm{~g}(32.9 \mathrm{mg}, 84 \%)$.

(Conditions $B$ )

Under an argon atmosphere, a solution of $N$-silyl $\alpha$-iminoester $1 \mathbf{d}(41.6 \mathrm{mg}, 0.15 \mathrm{mmol})$ in DMF $(0.50 \mathrm{~mL})$ was stirred at $50{ }^{\circ} \mathrm{C}$ for $5 \mathrm{~min}$, and to it was added (4-chlorobutyl)magnesium bromide in THF ( $0.45 \mathrm{~mL}, 0.45 \mathrm{mmol}, 1.01 \mathrm{~N}, 3.0$ equiv) slowly. After the mixture was stirred for $1 \mathrm{~h}$, the reaction was quenched with sat. $\mathrm{NaHCO}_{3}$ aq. $(5.0 \mathrm{~mL})$, and the whole mixture was extracted with ethyl acetate $(10.0 \mathrm{~mL} \times 3)$. The combined extracts were washed with a solution of sat. $\mathrm{NaHCO}_{3}$ aq. (15 mL), dried over anhydrous $\mathrm{Na}_{2} \mathrm{SO}_{4}$, and concentrated in vacuo. The crude product was purified on silica gel TLC $\left(\mathrm{CH}_{2} \mathrm{Cl}_{2} / \mathrm{AcOEt}=21 / 2\right)$ to give tert-butyl 2-phenyl-2-(pyrrolidin-1-yl)acetate $\mathbf{4 g}(15.5 \mathrm{mg}, 40 \%)$ and $\mathbf{5 g}$ (3.70 mg, 9\%).

\section{(Conditions C)}

Under an argon atmosphere, a solution of $\mathrm{N}$-silyl $\alpha$-iminoester $1 \mathbf{d}(41.6 \mathrm{mg}, 0.15 \mathrm{mmol}$ ) and TMSOTf $(0.16 \mathrm{~mL}, 0.9 \mathrm{mmol}, 6.0$ equiv) in $\mathrm{DMF}(0.50 \mathrm{~mL})$ was stirred at room temperature for $5 \mathrm{~min}$, and to it was added (4-chlorobutyl)magnesium bromide in THF ( $1.53 \mathrm{~mL}, 0.75 \mathrm{mmol}, 0.49 \mathrm{~N}, 5.0$ equiv) slowly. After the mixture was stirred for $1 \mathrm{~h}$, the reaction was quenched with sat. $\mathrm{NaHCO}_{3}$ aq. $(5.0 \mathrm{~mL})$, and the whole mixture was extracted with ethyl acetate $(10.0 \mathrm{~mL} \times 3)$. The combined extracts were washed with a solution of sat. $\mathrm{NaHCO}_{3}$ aq. $(15 \mathrm{~mL})$, dried over anhydrous $\mathrm{Na}_{2} \mathrm{SO}_{4}$, and concentrated in vacuo. The crude product was purified on silica gel TLC ( $n$-hexane/AcOEt $=5 / 1$ ) to give tert-butyl 2-phenyl-2-(pyrrolidin-1-yl)acetate 4g (23.1 mg, 59\%)

tert-Butyl 2-phenyl-2-(pyrrolidin-1-yl)acetate (4g) $)^{14}$

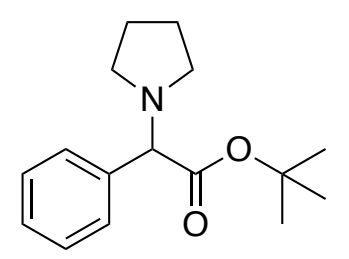


Yellow oil; ${ }^{1} \mathrm{H}$ NMR (400 MHz, $\left.\mathrm{CDCl}_{3}\right)$ $\delta$ 7.46-7.44 (m, 2H), 7.34-7.26 (m, 3H), 3.80 (s, $\left.1 \mathrm{H}\right)$, 2.62-2.53 (m, $2 \mathrm{H}), 2.50-2.40(\mathrm{~m}, 2 \mathrm{H}), 1.83-1.73(\mathrm{~m}, 4 \mathrm{H}), 1.38(\mathrm{~s}, 9 \mathrm{H}) ;{ }^{13} \mathrm{C} \mathrm{NMR}\left(100 \mathrm{MHz}, \mathrm{CDCl}_{3}\right) \delta 170.9,138.0$, $128.4,128.3,127.8,80.9,74.4,52.3,27.9,23.4$; IR (neat) 3060, 2973, 2875, 1734, 1454, 1365, 1253, 1146, 793, 751, $697 \mathrm{~cm}^{-1}$; HRMS (EI): Calcd for $\mathrm{C}_{16} \mathrm{H}_{23} \mathrm{NO}_{2}(\mathrm{M})^{+} 261.1729$ found 261.1736.

tert-Butyl 2-phenylpiperidine-2-carboxylate (5g)

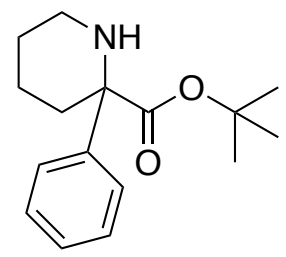

Yellow oil; ${ }^{1} \mathrm{H}$ NMR $\left(400 \mathrm{MHz}, \mathrm{CDCl}_{3}\right) \delta$ 7.51-7.48 (m, $\left.2 \mathrm{H}\right), 7.34-7.22(\mathrm{~m}, 3 \mathrm{H}), 3.03-2.99(\mathrm{~m}, 1 \mathrm{H})$, 2.83-2.76 (m, $1 \mathrm{H}), 2.42-2.20(\mathrm{~m}, 2 \mathrm{H}), 1.80-1.49(\mathrm{~m}, 5 \mathrm{H}), 1.44(\mathrm{~s}, 9 \mathrm{H}) ;{ }^{13} \mathrm{C} \mathrm{NMR}\left(100 \mathrm{MHz}, \mathrm{CDCl}_{3}\right) \delta$ 173.8, 143.8, 128.3, 127.1, 125.1, 81.2, 65.9, 43.7, 35.2, 27.9, 25.1, 22.5; IR (neat) 3341, 3063, 2976, 2931, 1723, 1452, 1384, 1367, 1240, 1155, 1123, 839, $699 \mathrm{~cm}^{-1}$; HRMS (EI): Calcd for $\mathrm{C}_{16} \mathrm{H}_{23} \mathrm{NO}_{2}(\mathrm{M})^{+}$ 261.1729 found 261.1735 .

\section{Syntheses of methyl 2-phenyl-2-(piperidin-1-yl)acetate (6)}

(Conditions A)

Under an argon atmosphere, a solution of $N$-silyl $\alpha$-iminoester $1 \mathbf{b}$ (35.3 $\mathrm{mg}, 0.15 \mathrm{mmol}$ ) in DMF $(0.50 \mathrm{~mL})$ was stirred at $0{ }^{\circ} \mathrm{C}$ for $5 \mathrm{~min}$, and to it was added (5-chloropentyl)magnesium bromide in THF ( $0.64 \mathrm{~mL}, 0.45 \mathrm{mmol}, 0.70 \mathrm{~N}, 3.0$ equiv) slowly. After the mixture was stirred for $1 \mathrm{~h}$, the reaction was quenched with sat. $\mathrm{NaHCO}_{3}$ aq. $(5.0 \mathrm{~mL})$, and the whole mixture was extracted with ethyl acetate (10.0 $\mathrm{mL} \times 3$ ). The combined extracts were washed with a solution of sat. $\mathrm{NaHCO}_{3}$ aq. $(15 \mathrm{~mL})$, dried over anhydrous $\mathrm{Na}_{2} \mathrm{SO}_{4}$, and concentrated in vacuo. The crude product was purified by silica gel TLC $\left(\mathrm{CH}_{2} \mathrm{Cl}_{2} / \mathrm{MeOH}=6 / 1\right)$ to give ethyl 2-phenyl-2-(piperidin-1-yl)acetate 6 (16.0 mg, 46\%) .

(Conditions B) [TH-292]

Under an argon atmosphere, a solution of $N$-silyl $\alpha$-iminoester $1 \mathbf{b}$ (35.3 $\mathrm{mg}, 0.15 \mathrm{mmol}$ ) in DMF $\left(0.50 \mathrm{~mL}\right.$ ) was stirred at $50{ }^{\circ} \mathrm{C}$ for $5 \mathrm{~min}$, and to it was added (5-chloropentyl)magnesium bromide in THF ( $0.64 \mathrm{~mL}, 0.45 \mathrm{mmol}, 0.70 \mathrm{~N}, 3.0$ equiv) slowly. After the mixture was stirred for $1 \mathrm{~h}$, the reaction was quenched with sat. $\mathrm{NaHCO}_{3}$ aq. $(5.0 \mathrm{~mL})$, and the whole mixture was extracted with ethyl acetate $(10.0 \mathrm{~mL} \times 3)$. The combined extracts were washed with a solution of sat. $\mathrm{NaHCO}_{3}$ aq. $(15 \mathrm{~mL})$, dried over anhydrous $\mathrm{Na}_{2} \mathrm{SO}_{4}$, and concentrated in vacuo. The crude product was purified on silica gel TLC $\left(\mathrm{CH}_{2} \mathrm{Cl}_{2} / \mathrm{MeOH}=6 / 1\right)$ to give methyl 2-phenyl-2-(piperidin-1-yl)acetate 6 (17.5 mg, 50\%) .

Methyl 2-phenyl-2-(piperidin-1-yl)acetate (6) ${ }^{15}$ 


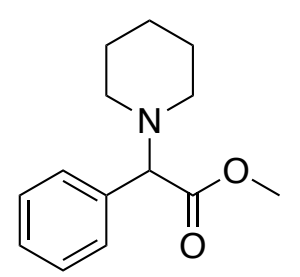

Yellow oil; ${ }^{1} \mathrm{H}$ NMR (500 MHz, $\left.\mathrm{CDCl}_{3}\right) \delta$ 7.44-7.39 (m, 2H), 7.35-7.26 (m, 3H), $3.97(\mathrm{~s}, 1 \mathrm{H}), 3.68(\mathrm{~s}, 3 \mathrm{H})$, 2.43-2.30 (m, 4H), 1.62-1.57 (m, 4H), 1.47-1.39 (m, 2H); $\left.{ }^{13} \mathrm{C} \mathrm{NMR} \mathrm{(125} \mathrm{MHz,} \mathrm{CDCl}_{3}\right) \delta 172.4,136.2$, $128.8,128.4,128.2,75.0,52.4,51.9,25.8,24.3$; IR (neat) 2937, 2852, 1740, 1683, 1444, 1265, 1200, 1158, 1016, 870, 756, $696 \mathrm{~cm}^{-1}$; HRMS (EI): Calcd for $\mathrm{C}_{14} \mathrm{H}_{19} \mathrm{NO}_{2}(\mathrm{M})^{+} 233.1416$ found 233.1420 .

\section{Syntheses of methyl 2-(azepan-1-yl)-2-phenylacetate (8)}

\section{(Conditions A)}

Under an argon atmosphere, a solution of $N$-silyl $\alpha$-iminoester $\mathbf{1 b}(35.3 \mathrm{mg}, 0.15 \mathrm{mmol}$ ) in DMF $(0.50 \mathrm{~mL})$ was stirred at $0{ }^{\circ} \mathrm{C}$ for $5 \mathrm{~min}$, and to it was added (6-chlorohexyl)magnesium bromide in THF ( $0.47 \mathrm{~mL}, 0.45 \mathrm{mmol}, 0.96 \mathrm{~N}, 3.0$ equiv) slowly. After the mixture was stirred for $2 \mathrm{~h}$, the reaction was quenched with sat. $\mathrm{NaHCO}_{3}$ aq. $(5.0 \mathrm{~mL})$, and the whole mixture was extracted with ethyl acetate $(10.0 \mathrm{~mL} \times 3)$. The combined extracts were washed with a solution of sat. $\mathrm{NaHCO}_{3}$ aq. $(15 \mathrm{~mL})$, dried over anhydrous $\mathrm{Na}_{2} \mathrm{SO}_{4}$, and concentrated in vacuo. The crude product was purified on silica gel TLC ( $n$-hexane/AcOEt = 6/1) to give methyl 2-(azepan-1-yl)-2-phenylacetate 8 (23.9 mg, 64\%).

\section{(Conditions B)}

Under an argon atmosphere, a solution of $N$-silyl $\alpha$-iminoester $\mathbf{1 b}(35.3 \mathrm{mg}, 0.15 \mathrm{mmol})$ in DMF $(0.50 \mathrm{~mL})$ was stirred at $50{ }^{\circ} \mathrm{C}$ for $5 \mathrm{~min}$, and to it was added (6-chlorohexyl)magnesium bromide in THF ( $0.47 \mathrm{~mL}, 0.45 \mathrm{mmol}, 0.96 \mathrm{~N}, 3.0$ equiv) slowly. After the mixture was stirred for $2 \mathrm{~h}$, the reaction was quenched with sat. $\mathrm{NaHCO}_{3}$ aq. $(5.0 \mathrm{~mL})$, and the whole mixture was extracted with ethyl acetate $(10.0 \mathrm{~mL} \times 3)$. The combined extracts were washed with a solution of sat. $\mathrm{NaHCO}_{3}$ aq. $(15 \mathrm{~mL})$, dried over anhydrous $\mathrm{Na}_{2} \mathrm{SO}_{4}$, and concentrated in vacuo. The crude product was purified on silica gel TLC $\left(\mathrm{CH}_{2} \mathrm{Cl}_{2} / \mathrm{MeOH}=10 / 1\right)$ to give methyl 2-(azepan-1-yl)-2-phenylacetate 8 (7.9 mg, 21\%) .

Methyl 2-(azepan-1-yl)-2-phenylacetate (8)<smiles>COC(=O)C(c1ccccc1)N1CCCCCC1</smiles>

Yellow oil; ${ }^{1} \mathrm{H}$ NMR $\left(500 \mathrm{MHz}, \mathrm{CDCl}_{3}\right) \delta$ 7.38-7.28 (m, 5H), $4.36(\mathrm{~s}, 1 \mathrm{H}), 3.69(\mathrm{~s}, 3 \mathrm{H}), 3.52(\mathrm{dd}, J=7.2$, $7.2 \mathrm{~Hz}, 2 \mathrm{H}$ ), 2.58 (ddd, $J=7.2,7.2,11.2 \mathrm{~Hz}, 1 \mathrm{H}$ ), 2.49 (ddd, J=7.2, 7.2, $11.2 \mathrm{~Hz}, 1 \mathrm{H}$ ), 1.76 (ddt, $J=7.2$, 7.2, 7.2 Hz, 2H), 1.52 (ddt, $J=7.2,7.2,7.2 \mathrm{~Hz}, 2 \mathrm{H}), 1.45-1.31(\mathrm{~m}, 4 \mathrm{H}) ;{ }^{13} \mathrm{C} \mathrm{NMR}\left(125 \mathrm{MHz}, \mathrm{CDCl}_{3}\right) \delta$ 173.6, 138.2, 128.7, 128.0, 127.3, 65.5, 52.2, 47.6, 45.0, 32.5, 29.8, 26.7, 26.5; IR (neat) 3063, 2933, 2856, 1736, 1458, 1316, 1166, 1007, 793, 755, $699 \mathrm{~cm}^{-1}$; HRMS (EI): Calcd for $\mathrm{C}_{15} \mathrm{H}_{21} \mathrm{NO}_{2}(\mathrm{M})^{+}$ 247.1572 found 247.1569 . 
11. [Table S5] Optimization of Tandem N-Alkylation/intermolecular Nucleophilic Addition

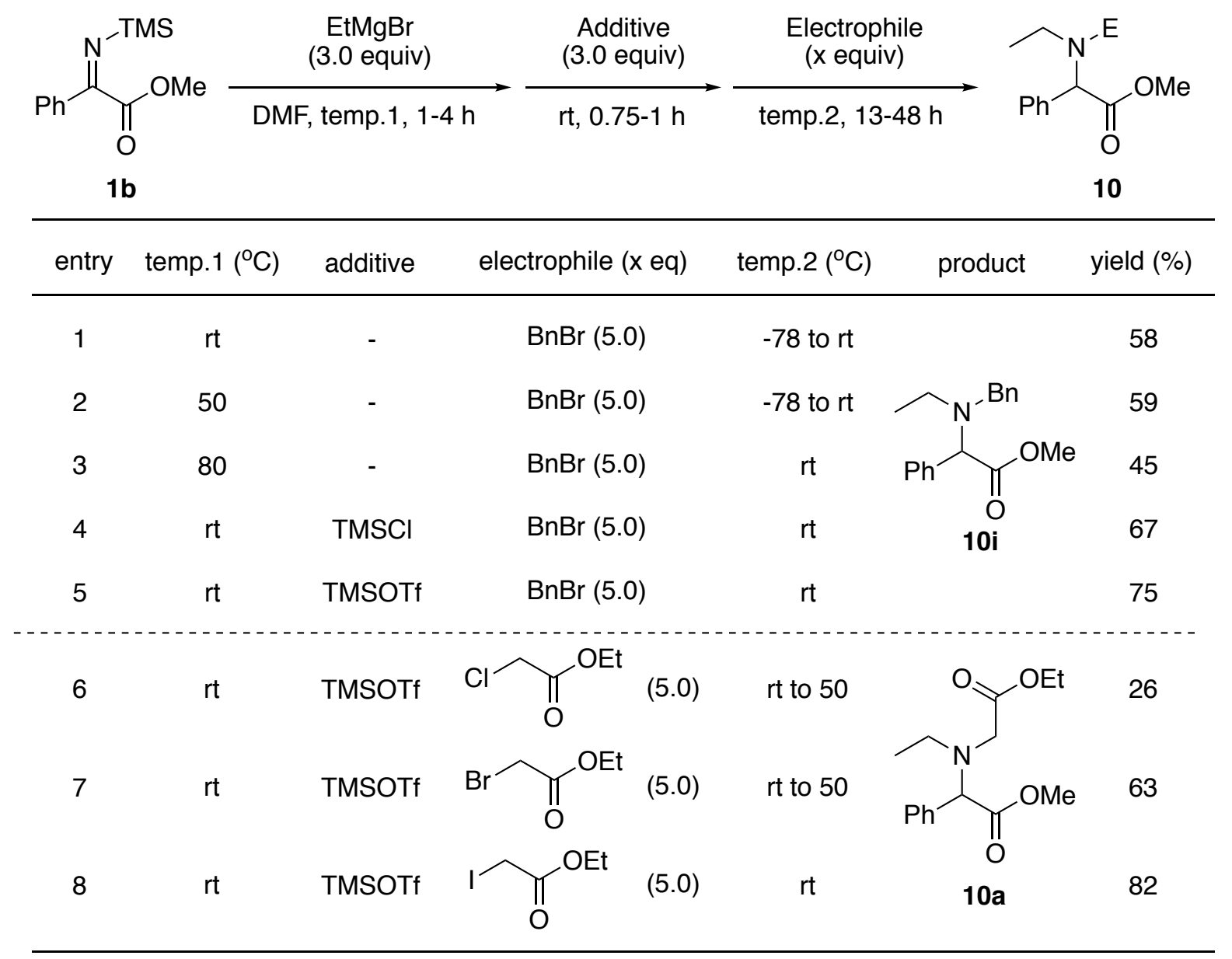

(Table S5, entry 1)

Under an argon atmosphere, a solution of $N$-silyl $\alpha$-iminoester $\mathbf{1 b}$ ( $35.3 \mathrm{mg}, 0.15 \mathrm{mmol}$ ) in DMF $(0.50 \mathrm{~mL})$ was stirred at room temperature for $5 \mathrm{~min}$, and to it was added $\mathrm{EtMgBr}$ in THF $(0.51 \mathrm{~mL}$, $0.45 \mathrm{mmol}, 0.89 \mathrm{~N}, 3.0$ equiv) slowly. After the mixture was stirred for $1.5 \mathrm{~h}$, to it was added benzyl bromide $\left(0.090 \mathrm{~mL}, 0.75 \mathrm{mmol}, 5.0\right.$ equiv) at $-78{ }^{\circ} \mathrm{C}$ and the mixture was gradually warmed to room temperature during $48 \mathrm{~h}$. The reaction was quenched with sat. $\mathrm{NaHCO}_{3}$ aq. $(5.0 \mathrm{~mL}$ ), and the whole mixture was extracted with ethyl acetate $(10.0 \mathrm{~mL} \times 3)$. The combined extracts were washed with a solution of sat. $\mathrm{NaHCO}_{3}$ aq. (15 mL), dried over anhydrous $\mathrm{Na}_{2} \mathrm{SO}_{4}$, and concentrated in vacuo. The crude product was purified on silica gel TLC ( $n$-hexane/AcOEt $=5 / 1$ ) to give methyl 2-[benzyl(ethyl)amino]-2-phenylacetate 10i (24.6 mg, 58\%).

Methyl 2-[benzyl(ethyl)amino]-2-phenylacetate (10i) 


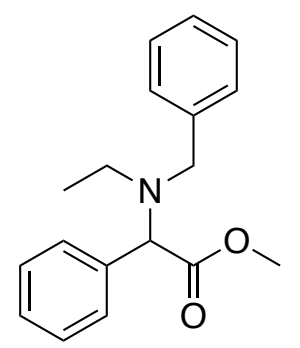

Yield 58\%; Yellow oil; ${ }^{1} \mathrm{H}$ NMR $\left(400 \mathrm{MHz}, \mathrm{CDCl}_{3}\right) \delta$ 7.42-7.19 (m, 10H), $4.65(\mathrm{~s}, 1 \mathrm{H}), 3.76(\mathrm{~d}, J=14.4 \mathrm{~Hz}$, $1 \mathrm{H}), 3.75(\mathrm{~s}, 3 \mathrm{H}), 3.69(\mathrm{~d}, J=14.4 \mathrm{~Hz}, 1 \mathrm{H}), 2.70-2.58(\mathrm{~m}, 2 \mathrm{H}), 1.01(\mathrm{dd}, J=7.1,7.1 \mathrm{~Hz}, 3 \mathrm{H}) ;{ }^{13} \mathrm{C} \mathrm{NMR}$ $\left(125 \mathrm{MHz}, \mathrm{CDCl}_{3}\right) \delta 172.7,140.0,137.1,128.6,128.5,128.3,128.1,127.8,126.8,67.5,54.2,51.4,44.2$, 12.4; IR (neat) 3029, 2968, 2842, 1739, 1601, 1494, 1453, 1202, 1162, 1063, 996, 909, 732, $699 \mathrm{~cm}^{-1}$; HRMS (EI): Calcd for $\mathrm{C}_{18} \mathrm{H}_{21} \mathrm{NO}_{2}(\mathrm{M})^{+} 283.1572$ found 283.1574 .

\section{(Table S5, entry 2)}

Under an argon atmosphere, a solution of $\mathrm{N}$-silyl $\alpha$-iminoester $\mathbf{1 b}(35.3 \mathrm{mg}, 0.15 \mathrm{mmol}$ ) in DMF $(0.50 \mathrm{~mL})$ was stirred at $50^{\circ} \mathrm{C}$ for $5 \mathrm{~min}$, and to it was added EtMgBr in THF (0.51 mL, $0.45 \mathrm{mmol}, 0.89$ $\mathrm{N}, 3.0$ equiv) slowly. After the mixture was stirred for $4 \mathrm{~h}$, to it was added benzyl bromide $(0.090 \mathrm{~mL}$, $0.75 \mathrm{mmol}, 5.0$ equiv) at $-78{ }^{\circ} \mathrm{C}$ and the mixture was gradually warmed to room temperature during $27 \mathrm{~h}$. The reaction was quenched with sat. $\mathrm{NaHCO}_{3}$ aq. $(5.0 \mathrm{~mL})$, and the whole mixture was extracted with ethyl acetate $(10.0 \mathrm{~mL} \times 3)$. The combined extracts were washed with a solution of sat. $\mathrm{NaHCO}_{3}$ aq. (15 mL), dried over anhydrous $\mathrm{Na}_{2} \mathrm{SO}_{4}$, and concentrated in vacuo. The crude product was purified on silica gel TLC ( $n$-hexane/AcOEt $=5 / 1$ ) to give methyl 2-[benzyl(ethyl)amino]-2-phenylacetate 10i (24.9 mg, 59\%).

(Table S5, entry 3)

Under an argon atmosphere, a solution of $N$-silyl $\alpha$-iminoester $\mathbf{1 b}(35.3 \mathrm{mg}, 0.15 \mathrm{mmol}$ ) in DMF $(0.50 \mathrm{~mL})$ was stirred at $80^{\circ} \mathrm{C}$ for $5 \mathrm{~min}$, and to it was added $\mathrm{EtMgBr}$ in THF $(0.51 \mathrm{~mL}, 0.45 \mathrm{mmol}, 0.89$ $N, 3.0$ equiv) slowly. After the mixture was stirred for $1.5 \mathrm{~h}$, to it was added benzyl bromide $(0.090 \mathrm{~mL}$, $0.75 \mathrm{mmol}, 5.0$ equiv) at room temperature and the mixture was stirred at room temperature for 13 h. The reaction was quenched with sat. $\mathrm{NaHCO}_{3}$ aq. $(5.0 \mathrm{~mL})$, and the whole mixture was extracted with ethyl acetate $(10.0 \mathrm{~mL} \times 3)$. The combined extracts were washed with a solution of sat. $\mathrm{NaHCO}_{3}$ aq. (15 mL), dried over anhydrous $\mathrm{Na}_{2} \mathrm{SO}_{4}$, and concentrated in vacuo. The crude product was purified on silica gel TLC ( $n$-hexane/AcOEt $=5 / 1)$ to give methyl 2-[benzyl(ethyl)amino]-2-phenylacetate 10i (19.0 mg, 45\%).

(Table S5, entry 4)

Under an argon atmosphere, a solution of $N$-silyl $\alpha$-iminoester $1 \mathbf{b}$ (35.3 mg, $0.15 \mathrm{mmol}$ ) in DMF $(0.50 \mathrm{~mL})$ was stirred at room temperature for $5 \mathrm{~min}$, and to it was added $\mathrm{EtMgBr}$ in $\mathrm{THF}(0.51 \mathrm{~mL}$, $0.45 \mathrm{mmol}, 0.89 \mathrm{~N}, 3.0$ equiv) slowly. After the mixture was stirred for $2 \mathrm{~h}$, to it was added TMSCl ( $0.060 \mathrm{~mL}, 0.75 \mathrm{mmol}, 5.0$ equiv) at room temperature. After stirring for $1 \mathrm{~h}$, to it was added benzyl bromide ( $0.090 \mathrm{~mL}, 0.75 \mathrm{mmol}, 5.0$ equiv) and the mixture was stirred for $21 \mathrm{~h}$. The reaction was quenched with sat. $\mathrm{NaHCO}_{3}$ aq. $(5.0 \mathrm{~mL}$ ), and the whole mixture was extracted with ethyl acetate $(10.0 \mathrm{~mL} \times 3)$. The combined extracts were washed with a solution of sat. $\mathrm{NaHCO}_{3}$ aq. $(15 \mathrm{~mL})$, dried 
over anhydrous $\mathrm{Na}_{2} \mathrm{SO}_{4}$, and concentrated in vacuo. The crude product was purified on silica gel TLC ( $n$-hexane/AcOEt = $5 / 1$ ) to give methyl 2-[benzyl(ethyl)amino]-2-phenylacetate 10i (28.5 mg, 67\%).

(Table S5, entry 5)

Under an argon atmosphere, a solution of $N$-silyl $\alpha$-iminoester $\mathbf{1 b}(35.3 \mathrm{mg}, 0.15 \mathrm{mmol}$ ) in DMF $(0.50 \mathrm{~mL})$ was stirred at room temperature for $5 \mathrm{~min}$, and to it was added EtMgBr in THF $(0.51 \mathrm{~mL}$, $0.45 \mathrm{mmol}, 0.89 \mathrm{~N}, 3.0$ equiv) slowly. After the mixture was stirred for $2.5 \mathrm{~h}$, to it was added TMSOTf ( $0.14 \mathrm{~mL}, 0.75 \mathrm{mmol}, 5.0$ equiv) at room temperature. After stirring for $1 \mathrm{~h}$, to it was added benzyl bromide ( $0.090 \mathrm{~mL}, 0.75 \mathrm{mmol}, 5.0$ equiv) and the mixture was stirred for $25 \mathrm{~h}$. The reaction was quenched with sat. $\mathrm{NaHCO}_{3}$ aq. $(5.0 \mathrm{~mL})$, and the whole mixture was extracted with ethyl acetate $(10.0 \mathrm{~mL} \times 3)$. The combined extracts were washed with a solution of sat. $\mathrm{NaHCO}_{3}$ aq. $(15 \mathrm{~mL})$, dried over anhydrous $\mathrm{Na}_{2} \mathrm{SO}_{4}$, and concentrated in vacuo. The crude product was purified on silica gel TLC ( $n$-hexane/AcOEt = $5 / 1$ ) to give methyl 2-[benzyl(ethyl)amino]-2-phenylacetate 10i (31.8 mg, 75\%).

(Table S5, entry 6)

Under an argon atmosphere, a solution of $N$-silyl $\alpha$-iminoester $\mathbf{1 b}(35.3 \mathrm{mg}, 0.15 \mathrm{mmol})$ in DMF $(0.50 \mathrm{~mL})$ was stirred at room temperature for $5 \mathrm{~min}$, and to it was added $\mathrm{EtMgBr}$ in $\mathrm{THF}(0.50 \mathrm{~mL}$, $0.45 \mathrm{mmol}, 0.90 \mathrm{~N}, 3.0$ equiv) slowly. After the mixture was stirred for $1 \mathrm{~h}$, to it was added TMSOTf ( $0.080 \mathrm{~mL}, 0.45 \mathrm{mmol}, 3.0$ equiv) at room temperature. After stirring for $45 \mathrm{~min}$, to it was added ethyl 2-chloroacetate $\left(0.080 \mathrm{~mL}, 0.75 \mathrm{mmol}, 5.0\right.$ equiv) and the mixture was warmed to $50{ }^{\circ} \mathrm{C}$ and stirred for $43 \mathrm{~h}$. The reaction was quenched with sat. $\mathrm{NaHCO}_{3}$ aq. $(5.0 \mathrm{~mL})$, and the whole mixture was extracted with ethyl acetate $(10.0 \mathrm{~mL} \times 3)$. The combined extracts were washed with a solution of sat. $\mathrm{NaHCO}_{3}$ aq. $(15 \mathrm{~mL})$, dried over anhydrous $\mathrm{Na}_{2} \mathrm{SO}_{4}$, and concentrated in vacuo. The crude product was purified on silica gel TLC ( $n$-hexane/AcOEt $=6 / 1)$ to give methyl 2-[(2-ethoxy-2-oxoethyl)(ethyl)amino]-2-phenylacetate 10a (11.0 mg, 26\%).

Methyl 2-[(2-ethoxy-2-oxoethyl)(ethyl)amino]-2-phenylacetate (10a)

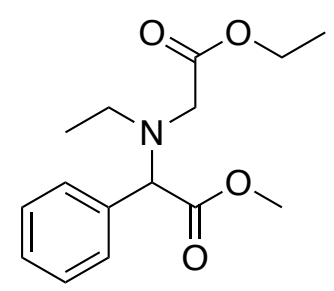

Yield 26\%; Yellow oil; ${ }^{1} \mathrm{H}$ NMR $\left(500 \mathrm{MHz}, \mathrm{CDCl}_{3}\right) \delta$ 7.44-7.42 (m, 2H), 7.35-7.29 (m, 3H), $4.86(\mathrm{~s}, 1 \mathrm{H})$, $4.10(\mathrm{q}, J=7.1 \mathrm{~Hz}, 2 \mathrm{H}), 3.71(\mathrm{~s}, 3 \mathrm{H}), 3.51(\mathrm{~d}, J=17.7 \mathrm{~Hz}, 1 \mathrm{H}), 3.33(\mathrm{~d}, J=17.7 \mathrm{~Hz}, 1 \mathrm{H}), 2.82-2.69(\mathrm{~m}$, $2 \mathrm{H}), 1.22(\mathrm{~d}, J=7.1 \mathrm{~Hz}, 3 \mathrm{H}), 1.10(\mathrm{dd}, J=7.3,7.3 \mathrm{~Hz}, 3 \mathrm{H}) ;{ }^{13} \mathrm{C} \mathrm{NMR}\left(125 \mathrm{MHz}, \mathrm{CDCl}_{3}\right) \delta 172.8,171.6$, 136.3, 128.8, 128.5, 128.2, 69.0, 60.2, 51.8, 50.4, 46.2, 14.2, 13.0; IR (neat) 2981, 2973, 2932, 1739, $1731,1458,1384,1368,1255,1187,1180,1146,1035,749,698 \mathrm{~cm}^{-1}$; HRMS (EI): Calcd for $\mathrm{C}_{15} \mathrm{H}_{21} \mathrm{NO}_{4}$ $(\mathrm{M})^{+} 279.1471$ found 279.1463 .

(Table S5, entry 7)

Under an argon atmosphere, a solution of $N$-silyl $\alpha$-iminoester $\mathbf{1 b}(35.3 \mathrm{mg}, 0.15 \mathrm{mmol})$ in DMF 
$(0.50 \mathrm{~mL})$ was stirred at room temperature for $5 \mathrm{~min}$, and to it was added $\mathrm{EtMgBr}$ in $\mathrm{THF}(0.50 \mathrm{~mL}$, $0.45 \mathrm{mmol}, 0.90 \mathrm{~N}, 3.0$ equiv) slowly. After the mixture was stirred for $1 \mathrm{~h}$, to it was added TMSOTf ( $0.080 \mathrm{~mL}, 0.45 \mathrm{mmol}, 3.0$ equiv) at room temperature. After stirring for $45 \mathrm{~min}$, to it was added ethyl 2-bromoacetate $\left(0.080 \mathrm{~mL}, 0.75 \mathrm{mmol}, 5.0\right.$ equiv) and the mixture was warmed to $50{ }^{\circ} \mathrm{C}$ and stirred for $20.5 \mathrm{~h}$. The reaction was quenched with sat. $\mathrm{NaHCO}_{3}$ aq. $(5.0 \mathrm{~mL})$, and the whole mixture was extracted with ethyl acetate $(10.0 \mathrm{~mL} \times 3)$. The combined extracts were washed with a solution of sat. $\mathrm{NaHCO}_{3}$ aq. (15 mL), dried over anhydrous $\mathrm{Na}_{2} \mathrm{SO}_{4}$, and concentrated in vacuo. The crude product was purified on silica gel TLC ( $n$-hexane/AcOEt $=6 / 1)$ to give methyl 2-[(2-ethoxy-2-oxoethyl)(ethyl)amino]-2-phenylacetate 10a (26.5 mg, 63\%).

(Table S5, entry 8)

Under an argon atmosphere, a solution of $N$-silyl $\alpha$-iminoester $\mathbf{1 b}(35.3 \mathrm{mg}, 0.15 \mathrm{mmol})$ in DMF $(0.50 \mathrm{~mL})$ was stirred at room temperature for $5 \mathrm{~min}$, and to it was added $\mathrm{EtMgBr}$ in $\mathrm{THF}(0.50 \mathrm{~mL}$, $0.45 \mathrm{mmol}, 0.90 \mathrm{~N}, 3.0$ equiv) slowly. After the mixture was stirred for $1 \mathrm{~h}$, to it was added TMSOTf ( $0.080 \mathrm{~mL}, 0.45 \mathrm{mmol}, 3.0$ equiv) at room temperature. After stirring for $45 \mathrm{~min}$, to it was added ethyl 2-iodoacetate $(0.090 \mathrm{~mL}, 0.75 \mathrm{mmol}, 5.0$ equiv) and the mixture was stirred for $19 \mathrm{~h}$. The reaction was quenched with sat. $\mathrm{NaHCO}_{3}$ aq. $(5.0 \mathrm{~mL})$, and the whole mixture was extracted with ethyl acetate $(10.0 \mathrm{~mL} \times 3)$. The combined extracts were washed with a solution of sat. $\mathrm{NaHCO}_{3}$ aq. $(15 \mathrm{~mL})$, dried over anhydrous $\mathrm{Na}_{2} \mathrm{SO}_{4}$, and concentrated in vacuo. The crude product was purified on silica gel TLC ( $n$-hexane/AcOEt $=6 / 1$ ) to give methyl 2-[(2-ethoxy-2-oxoethyl)(ethyl)amino]-2-phenylacetate 10a (34.4 mg, 82\%).

\section{2. [Table 2] Tandem $N, N$-Dialkylation Reaction of $N$-Silyl $\alpha$-Iminoester}

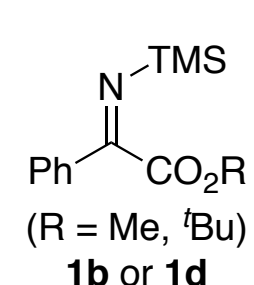

$1 \mathrm{~b}$ or $1 \mathrm{~d}$
1. EtMgBr (3.0 equiv) DMF, rt, $1 \mathrm{~h}$

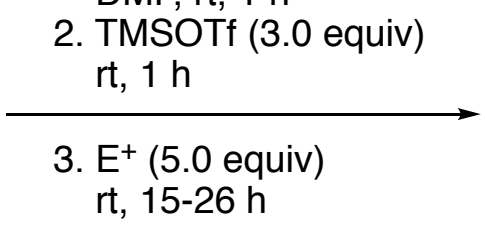

$\mathrm{rt}, 15-26 \mathrm{~h}$<smiles>[R]OC(=O)C(c1ccccc1)N(F)CC</smiles>

10

(Table 2, entry 1): Same as in entry 8, Table S5.

(Table 2, entry 2)

Under an argon atmosphere, a solution of $N$-silyl $\alpha$-iminoester $1 \mathbf{d}(41.6 \mathrm{mg}, 0.15 \mathrm{mmol}$ ) in DMF $(0.50 \mathrm{~mL})$ was stirred at room temperature for $5 \mathrm{~min}$, and to it was added $\mathrm{EtMgBr}$ in $\mathrm{THF}(0.50 \mathrm{~mL}$, $0.45 \mathrm{mmol}, 0.90 \mathrm{~N}, 3.0$ equiv) slowly. After the mixture was stirred for $1 \mathrm{~h}$, to it was added TMSOTf ( $0.080 \mathrm{~mL}, 0.45 \mathrm{mmol}, 3.0$ equiv) at room temperature. After stirring for $1 \mathrm{~h}$, to it was added ethyl 2-iodoacetate $(0.090 \mathrm{~mL}, 0.75 \mathrm{mmol}, 5.0$ equiv) and the mixture was stirred for $26 \mathrm{~h}$. The reaction was quenched with sat. $\mathrm{NaHCO}_{3}$ aq. $(5.0 \mathrm{~mL})$, and the whole mixture was extracted with ethyl acetate $(10.0 \mathrm{~mL} \times 3)$. The combined extracts were washed with a solution of sat. $\mathrm{NaHCO}_{3}$ aq. $(15 \mathrm{~mL})$, dried over anhydrous $\mathrm{Na}_{2} \mathrm{SO}_{4}$, and concentrated in vacuo. The crude product was purified on silica gel TLC ( $n$-hexane/AcOEt $=5 / 1)$ to give tert-butyl 2-[(2-ethoxy-2-oxoethyl)(ethyl)amino]-2-phenylacetate 
10b (42.9 mg, 89\%).

tert-Butyl 2-[(2-ethoxy-2-oxoethyl)(ethyl)amino]-2-phenylacetate (10b)<smiles>CCOC(=O)CN(CC)C(C(=O)OC(C)(C)C)c1ccccc1</smiles>

Yield 89\%; Yellow oil; ${ }^{1} \mathrm{H}$ NMR $\left(400 \mathrm{MHz}, \mathrm{CDCl}_{3}\right) \delta$ 7.45-7.43 (m, 2H),7.34-7.26 (m, 3H), $4.69(\mathrm{~s}, 1 \mathrm{H})$, 4.09 (q, J= $7.1 \mathrm{~Hz}, 2 \mathrm{H}), 3.49$ (d, J =17.4 Hz, 1H), 3.34 (d, J=17.4 Hz, 1H), 2.83-2.70 (m, $2 \mathrm{H}), 1.43$ (s, $9 \mathrm{H}), 1.22(\mathrm{~d}, J=7.1 \mathrm{~Hz}, 3 \mathrm{H}), 1.10(\mathrm{dd}, J=7.3,7.3 \mathrm{~Hz}, 3 \mathrm{H}) ;{ }^{13} \mathrm{C} \mathrm{NMR}\left(100 \mathrm{MHz}, \mathrm{CDCl}_{3}\right) \delta 171.9,171.5$, 137.0, 128.7, 128.3, 127.9, 81.2, 69.5, 60.1, 50.7, 46.4, 28.0, 14.2, 13.1; IR (neat) 2981, 2973, 2932, 1739, 1731, 1458, 1384, 1368, 1255, 1187, 1180, 1146, 1035, 749, $698 \mathrm{~cm}^{-1}$; HRMS (EI): Calcd for $\mathrm{C}_{18} \mathrm{H}_{27} \mathrm{NO}_{4}(\mathrm{M})^{+} 321.1940$ found 321.1929 .

\section{(Table 2, entry 3)}

Under an argon atmosphere, a solution of $N$-silyl $\alpha$-iminoester $1 \mathbf{d}(41.6 \mathrm{mg}, 0.15 \mathrm{mmol})$ in DMF $(0.50 \mathrm{~mL})$ was stirred at room temperature for $5 \mathrm{~min}$, and to it was added EtMgBr in THF $(0.49 \mathrm{~mL}$, $0.45 \mathrm{mmol}, 0.92 \mathrm{~N}, 3.0$ equiv) slowly. After the mixture was stirred for $1 \mathrm{~h}$, to it was added TMSOTf ( $0.080 \mathrm{~mL}, 0.45 \mathrm{mmol}, 3.0$ equiv) at room temperature. After stirring for $1 \mathrm{~h}$, to it was added tert-butyl 2-iodoacetate $(0.11 \mathrm{~mL}, 0.75 \mathrm{mmol}, 5.0$ equiv) and the mixture was stirred for $16 \mathrm{~h}$. The reaction was quenched with sat. $\mathrm{NaHCO}_{3}$ aq. $(5.0 \mathrm{~mL})$, and the whole mixture was extracted with ethyl acetate $(10.0 \mathrm{~mL} \times 3)$. The combined extracts were washed with a solution of sat. $\mathrm{NaHCO}_{3}$ aq. $(15 \mathrm{~mL})$, dried over anhydrous $\mathrm{Na}_{2} \mathrm{SO}_{4}$, and concentrated in vacuo. The crude product was purified on silica gel TLC ( $n$-hexane/AcOEt $=6 / 1$ ) to give tert-butyl 2-\{[2-(tert-butoxy)-2-oxoethyl](ethyl)amino\}-2-phenylacetate 10c (42.7 mg, 81\%).

tert-Butyl 2-\{[2-(tert-butoxy)-2-oxoethyl](ethyl)amino\}-2-phenylacetate (10c)<smiles>CCN(CC(=O)OC(C)(C)C)C(C(=O)OC(C)(C)C)c1ccccc1</smiles>

Yield 81\%; Yellow oil; ${ }^{1} \mathrm{H}$ NMR $\left(400 \mathrm{MHz}, \mathrm{CDCl}_{3}\right) \delta$ 7.46-7.43 (m, 2H), 7.34-7.26 (m, 3H), $4.70(\mathrm{~s}, 1 \mathrm{H})$, $3.38(\mathrm{~d}, J=17.6 \mathrm{~Hz}, 1 \mathrm{H}), 3.23(\mathrm{~d}, J=17.6 \mathrm{~Hz}, 1 \mathrm{H}), 2.82-2.69(\mathrm{~m}, 2 \mathrm{H}) 1.58(\mathrm{brs}, 1 \mathrm{H}), 1.42(\mathrm{~s}, 9) 1.42(\mathrm{~s}$, $9 \mathrm{H}), 1.09$ (dd, $J=7.1,7.1 \mathrm{~Hz}, 3 \mathrm{H}) ;{ }^{13} \mathrm{C} N M R\left(100 \mathrm{MHz}, \mathrm{CDCl}_{3}\right) \delta 171.6,171.2,137.3,128.7,128.3$, $127.8,81.0,80.4,69.7,51.4,46.2,28.1,28.0,13.2$; IR (neat) 2979, 2933, 2898, 1738, 1729, 1458, $1393,1386,1368,1219,1150,1146,851,749,698 \mathrm{~cm}^{-1}$; HRMS (EI): Calcd for $\mathrm{C}_{20} \mathrm{H}_{31} \mathrm{NO}_{4}(\mathrm{M})^{+}$ 349.2253 found 349.2244 . 
(Table 2, entry 4)

Under an argon atmosphere, a solution of $N$-silyl $\alpha$-iminoester $1 \mathbf{d}(41.6 \mathrm{mg}, 0.15 \mathrm{mmol})$ in DMF $(0.50 \mathrm{~mL})$ was stirred at room temperature for $5 \mathrm{~min}$, and to it was added EtMgBr in THF $(0.56 \mathrm{~mL}$, $0.45 \mathrm{mmol}, 0.80 \mathrm{~N}, 3.0$ equiv) slowly. After the mixture was stirred for $2 \mathrm{~h}$, to it was added TMSOTf ( $0.080 \mathrm{~mL}, 0.45 \mathrm{mmol}, 3.0$ equiv) at room temperature. After stirring for $1 \mathrm{~h}$, to it was added $\mathrm{N}, \mathrm{N}$-diethyl-2-iodoacetamide $(0.11 \mathrm{~mL}, 0.75 \mathrm{mmol}, 5.0$ equiv) and the mixture was stirred for $21 \mathrm{~h}$. The reaction was quenched with sat. $\mathrm{NaHCO}_{3}$ aq. $(5.0 \mathrm{~mL})$, and the whole mixture was extracted with ethyl acetate $(10.0 \mathrm{~mL} \times 3)$. The combined extracts were washed with a solution of sat. $\mathrm{NaHCO}_{3}$ aq. $(15 \mathrm{~mL})$, dried over anhydrous $\mathrm{Na}_{2} \mathrm{SO}_{4}$, and concentrated in vacuo. The crude product was purified on silica gel TLC ( $n$-hexane/AcOEt $=7 /$ 1) to give tert-butyl 2-\{[2-(diethylamino)-2-oxoethyl](ethyl)amino\}-2-phenylacetate $10 \mathrm{~d}$ (26.5 mg, 51\%).

tert-Butyl 2-\{[2-(diethylamino)-2-oxoethyl](ethyl)amino\}-2-phenylacetate (10d)

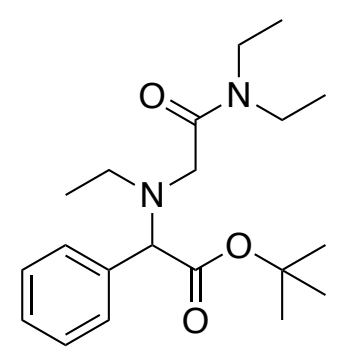

Yield 51\%; Yellow oil; ${ }^{1} \mathrm{H}$ NMR $\left(500 \mathrm{MHz}, \mathrm{CDCl}_{3}\right) \delta$ 7.45-7.44 (m, 2H), 7.34-7.27 (m, 3H), $4.59(\mathrm{~s}, 1 \mathrm{H})$, $3.44(\mathrm{~d}, J=15.0 \mathrm{~Hz}, 1 \mathrm{H}), 3.37-3.23(\mathrm{~m}, 5 \mathrm{H}$ including doublet at $3.33 \mathrm{ppm}, J=15.0 \mathrm{~Hz}, 1 \mathrm{H}), 2.84(\mathrm{dq}, J=$ 6.9, $14.2 \mathrm{~Hz}, 1 \mathrm{H}), 2.72(\mathrm{dq}, J=6.9,14.2 \mathrm{~Hz}, 1 \mathrm{H}), 1.41(\mathrm{~s}, 9 \mathrm{H}), 1.08(\mathrm{t}, J=7.0 \mathrm{~Hz}, 3 \mathrm{H}), 1.05(\mathrm{t}, J=7.0 \mathrm{~Hz}$, $3 \mathrm{H}), 0.98(\mathrm{dd}, J=6.9,6.9 \mathrm{~Hz}, 3 \mathrm{H}) ;{ }^{13} \mathrm{C} \mathrm{NMR}\left(125 \mathrm{MHz}, \mathrm{CDCl}_{3}\right) \delta 171.5,169.8,136.8,129.0,128.3$, $127.9,81.1,69.3,52.2,45.4,41.2,39.9,27.9,14.0,12.8,11.8$; IR (neat) 2973, 2933, 2877, 1735, 1647, $1639,1458,1371,1255,1148,793,754,700 \mathrm{~cm}^{-1}$; HRMS (El): Calcd for $\mathrm{C}_{20} \mathrm{H}_{32} \mathrm{~N}_{2} \mathrm{O}_{3}(\mathrm{M})^{+} 348.2413$ found 348.2415 .

(Table 2, entry 5)

Under an argon atmosphere, a solution of $N$-silyl $\alpha$-iminoester $1 \mathbf{d}(41.6 \mathrm{mg}, 0.15 \mathrm{mmol})$ in DMF $(0.50 \mathrm{~mL})$ was stirred at room temperature for $5 \mathrm{~min}$, and to it was added EtMgBr in THF $(0.56 \mathrm{~mL}$, $0.45 \mathrm{mmol}, 0.80 \mathrm{~N}, 3.0$ equiv) slowly. After the mixture was stirred for $1 \mathrm{~h}$, to it was added TMSOTf ( $0.080 \mathrm{~mL}, 0.45 \mathrm{mmol}, 3.0$ equiv) at room temperature. After stirring for $1 \mathrm{~h}$, to it was added S-ethyl 2-iodoethanethioate $(0.090 \mathrm{~mL}, 0.75 \mathrm{mmol}, 5.0$ equiv) and the mixture was stirred for $19 \mathrm{~h}$. The reaction was quenched with sat. $\mathrm{NaHCO}_{3}$ aq. $(5.0 \mathrm{~mL})$, and the whole mixture was extracted with ethyl acetate $(10.0 \mathrm{~mL} \times 3)$. The combined extracts were washed with a solution of sat. $\mathrm{NaHCO}_{3}$ aq. $(15 \mathrm{~mL})$, dried over anhydrous $\mathrm{Na}_{2} \mathrm{SO}_{4}$, and concentrated in vacuo. The crude product was purified on silica gel TLC ( $n$-hexane/AcOEt $=5 / 1)$ to give tert-butyl 2-\{ethyl[2-(ethylthio)-2-oxoethyl]amino\}-2-phenylacetate 10e (38.0 mg, 75\%). 
tert-Butyl 2-\{ethyl[2-(ethylthio)-2-oxoethyl]amino\}-2-phenylacetate (10e)<smiles>CCSC(=O)CN(CC)C(C(=O)OC(C)(C)C)c1ccccc1</smiles>

Yield 75\%; Yellow oil; ${ }^{1} \mathrm{H}$ NMR $\left(500 \mathrm{MHz}, \mathrm{CDCl}_{3}\right) \delta$ 7.46-7.45 (m, 2H), 7.36-7.27 (m, 3H), $4.67(\mathrm{~s}, 1 \mathrm{H})$, $3.52(\mathrm{~d}, J=17.7 \mathrm{~Hz}, 1 \mathrm{H}$ ), 3.45 (d, J=17.7 Hz, 1H), 2.82-2.70 (m, 4H), 1.48 (s, 9H), 1.20 (dd, J = 7.2, 7.2 $\mathrm{Hz}, 3 \mathrm{H}), 1.13(\mathrm{dd}, J=7.2,7.2 \mathrm{~Hz}, 3 \mathrm{H}) ;{ }^{13} \mathrm{C} \mathrm{NMR}\left(125 \mathrm{MHz} \mathrm{CDCl}_{3}\right) \delta 203.6,171.3,136.6,128.8,128.3$, 127.9, 81.7, 68.3, 60.5, 46.9, 28.1, 22.6, 14.5, 12.9; IR (neat) 3063, 2974, 2933, 2875, 1731, 1680, 1457, 1368, 1258, 1144, 1082, 952, 751, $698 \mathrm{~cm}^{-1}$; HRMS (EI): Calcd for $\mathrm{C}_{18} \mathrm{H}_{27} \mathrm{NO}_{3} \mathrm{~S}(\mathrm{M})^{+} 337.1712$ found 337.1722 .

(Table 2, entry 6)

Under an argon atmosphere, a solution of $N$-silyl $\alpha$-iminoester $1 \mathbf{d}(41.6 \mathrm{mg}, 0.15 \mathrm{mmol}$ ) in DMF $(0.50 \mathrm{~mL})$ was stirred at room temperature for $5 \mathrm{~min}$, and to it was added EtMgBr in THF $(0.56 \mathrm{~mL}$, $0.45 \mathrm{mmol}, 0.80 \mathrm{~N}, 3.0$ equiv) slowly. After the mixture was stirred for $1 \mathrm{~h}$, to it was added TMSOTf ( $0.080 \mathrm{~mL}, 0.45 \mathrm{mmol}, 3.0$ equiv) at room temperature. After stirring for $1 \mathrm{~h}$, to it was added 1-iodopropan-2-one $(0.070 \mathrm{~mL}, 0.75 \mathrm{mmol}, 5.0$ equiv) and the mixture was stirred for $18 \mathrm{~h}$. The reaction was quenched with sat. $\mathrm{NaHCO}_{3}$ aq. $(5.0 \mathrm{~mL})$, and the whole mixture was extracted with ethyl acetate $(10.0 \mathrm{~mL} \times 3)$. The combined extracts were washed with a solution of sat. $\mathrm{NaHCO}_{3}$ aq. $(15 \mathrm{~mL})$, dried over anhydrous $\mathrm{Na}_{2} \mathrm{SO}_{4}$, and concentrated in vacuo. The crude product was purified on silica gel TLC ( $n$-hexane/AcOEt = $5 / 1$ ) to give tert-butyl 2-[ethyl(2-oxopropyl)amino]-2-phenylacetate $10 f(34.7 \mathrm{mg}, 79 \%)$.

tert-Butyl 2-[ethyl(2-oxopropyl)amino]-2-phenylacetate (10f)<smiles>CCN(CC(C)=O)C(C(=O)OC(C)(C)C)c1ccccc1</smiles>

Yield 79\%; Yellow oil; ${ }^{1} \mathrm{H}$ NMR $\left(400 \mathrm{MHz}, \mathrm{CDCl}_{3}\right) \delta$ 7.41-7.27 (m, 5H), $4.58(\mathrm{~s}, 1 \mathrm{H}), 3.39(\mathrm{~d}, J=17.4 \mathrm{~Hz}$, $1 \mathrm{H}), 3.28(\mathrm{~d}, J=17.4 \mathrm{~Hz}, 1 \mathrm{H}), 2.79-2.63(\mathrm{~m}, 2 \mathrm{H}), 2.05(\mathrm{~s}, 3 \mathrm{H}), 1.45(\mathrm{~s}, 9 \mathrm{H}), 1.08(\mathrm{dd}, J=7.1,7.1 \mathrm{~Hz}, 3 \mathrm{H})$; ${ }^{13} \mathrm{C} \mathrm{NMR}\left(100 \mathrm{MHz}, \mathrm{CDCl}_{3}\right) \delta 210.1,171.4,137.0,128.7,128.4,128.0,81.5,69.2,60.7,47.3,28.4,27.3$, 12.7; IR (neat) 3062, 2979, 2931, 2872, 1734, 1675, 1452, 1369, 1254, 1148, 1036, 754, $699 \mathrm{~cm}^{-1}$; HRMS (EI): Calcd for $\mathrm{C}_{17} \mathrm{H}_{25} \mathrm{NO}_{3}(\mathrm{M})^{+} 291.1834$ found 291.1843.

(Table 2, entry 7)

Under an argon atmosphere, a solution of $N$-silyl $\alpha$-iminoester $1 \mathbf{d}(41.6 \mathrm{mg}, 0.15 \mathrm{mmol})$ in DMF $(0.50 \mathrm{~mL})$ was stirred at room temperature for $5 \mathrm{~min}$, and to it was added $\mathrm{EtMgBr}$ in THF $(0.56 \mathrm{~mL}$, 
$0.45 \mathrm{mmol}, 0.80 \mathrm{~N}, 3.0$ equiv) slowly. After the mixture was stirred for $1 \mathrm{~h}$, to it was added TMSOTf ( $0.080 \mathrm{~mL}, 0.45 \mathrm{mmol}, 3.0$ equiv) at room temperature. After stirring for $1 \mathrm{~h}$, to it was added 3-iodobutan-2-one $\left(0.13 \mathrm{~mL}, 0.75 \mathrm{mmol}, 5.0\right.$ equiv) and the mixture was warmed to $50{ }^{\circ} \mathrm{C}$ and stirred for $24 \mathrm{~h}$. The reaction was quenched with sat. $\mathrm{NaHCO}_{3}$ aq. $(5.0 \mathrm{~mL})$, and the whole mixture was extracted with ethyl acetate $(10.0 \mathrm{~mL} \times 3)$. The combined extracts were washed with a solution of sat. $\mathrm{NaHCO}_{3}$ aq. (15 mL), dried over anhydrous $\mathrm{Na}_{2} \mathrm{SO}_{4}$, and concentrated in vacuo. The crude product was purified on silica gel TLC (n-hexane/AcOEt $=5 / 1)$ to give ethyl $N$-[2-(tert-butoxy)-2-oxo-1-phenylethyl]- $N$-ethylalaninate $10 \mathrm{~g}(6.40 \mathrm{mg}, 13 \%)$.

Ethyl $N$-[2-(tert-butoxy)-2-oxo-1-phenylethyl]- $N$-ethylalaninate $(\mathbf{1 0 g})$<smiles>CCOC(=O)C(C)N(CC)C(C(=O)OC(C)(C)C)c1ccccc1</smiles>

$d r=63$ : 37; Yellow oil; ${ }^{1} \mathrm{H}$ NMR $\left(400 \mathrm{MHz}, \mathrm{CDCl}_{3}\right) \delta$ 7.43-7.39 $(\mathrm{m}, 2 \mathrm{H}), 7.33-7.24(\mathrm{~m}, 3 \mathrm{H}), 4.69(\mathrm{~s}$, $0.37 \mathrm{H}), 4.64(\mathrm{~s}, 0.63 \mathrm{H}), 4.19-4.13(\mathrm{~m}, 1.26 \mathrm{H}), 4.08(\mathrm{q}, J=7.2 \mathrm{~Hz}, 0.74 \mathrm{H}), 3.65(\mathrm{q}, J=7.1 \mathrm{~Hz}, 0.63 \mathrm{H})$, $3.53(q, J=7.1 \mathrm{~Hz}, 0.37 \mathrm{H}), 2.97-2.78(\mathrm{~m}, 2 \mathrm{H}), 1.44(\mathrm{~s}, 5.67 \mathrm{H}), 1.43(\mathrm{~s}, 3.33 \mathrm{H}), 1.34-1.28(\mathrm{~m}, 4.89 \mathrm{H})$, $1.24(\mathrm{t}, J=7.2 \mathrm{~Hz}, 1.11 \mathrm{H}), 1.00(\mathrm{dd}, J=7.0,7.0 \mathrm{~Hz}, 1.11 \mathrm{H}), 0.86(\mathrm{dd}, J=7.0,7.0 \mathrm{~Hz}, 1.89 \mathrm{H}) ;{ }^{13} \mathrm{C} \mathrm{NMR}$ $\left(125 \mathrm{MHz} \mathrm{CDCl}_{3}\right) \delta 174.5,174.3,172.7,171.8,138.5,138.1,128.7,128.6,128.2,128.1,127.6,127.5$, $81.1,80.9,68.5,66.9,60.2,60.0,56.5,55.9,42.7,41.5,28.0,27.9,16.7,15.8,15.6,15.5,14.3,14.3$; IR (neat) 3063, 2979, 2932, 2871, 1734, 1453, 1368, 1256, 1144, 1099, 1026, 789, $698 \mathrm{~cm}^{-1}$; HRMS (EI): Calcd for $\mathrm{C}_{19} \mathrm{H}_{29} \mathrm{NO}_{4}(\mathrm{M})^{+} 335.2097$ found 335.2087.

(Table 2, entry 9): Same as in entry 5, Table S5.

(Table 2, entry 10)

Under an argon atmosphere, a solution of $N$-silyl $\alpha$-iminoester $1 \mathbf{b}$ (35.3 mg, $0.15 \mathrm{mmol}$ ) in DMF $(0.50 \mathrm{~mL})$ was stirred at room temperature for $5 \mathrm{~min}$, and to it was added $\mathrm{EtMgBr}$ in $\mathrm{THF}(0.51 \mathrm{~mL}$, $0.45 \mathrm{mmol}, 0.88 \mathrm{~N}, 3.0$ equiv) slowly. After the mixture was stirred for $1 \mathrm{~h}$, to it was added TMSOTf $(0.080 \mathrm{~mL}, 0.45 \mathrm{mmol}, 3.0$ equiv) at room temperature. After stirring for $1 \mathrm{~h}$, to it was added 2-chloroacetyl chloride $(0.060 \mathrm{~mL}, 0.75 \mathrm{mmol}, 5.0$ equiv) and the mixture was stirred for $15 \mathrm{~h}$. The reaction was quenched with sat. $\mathrm{NaHCO}_{3}$ aq. $(5.0 \mathrm{~mL})$, and the whole mixture was extracted with ethyl acetate $(10.0 \mathrm{~mL} \times 3)$. The combined extracts were washed with a solution of sat. $\mathrm{NaHCO}_{3}$ aq. $(15 \mathrm{~mL})$, dried over anhydrous $\mathrm{Na}_{2} \mathrm{SO}_{4}$, and concentrated in vacuo. The crude product was purified on silica gel TLC ( $n$-hexane/AcOEt = $5 / 1$ ) to give methyl 2-(2-chloro- $N$-ethylacetamido)-2-phenylacetate 10j (27.0 mg, 67\%).

Methyl 2-(2-chloro- $N$-ethylacetamido)-2-phenylacetate (10j) 


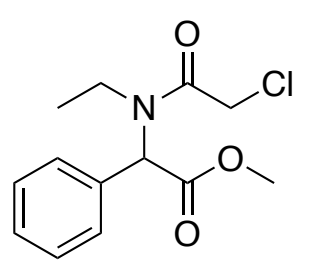

Yield 67\%; Yellow oil; ${ }^{1} \mathrm{H}$ NMR (400 MHz, $\left.\mathrm{CDCl}_{3}\right) \delta$ 7.40-7.27 (m, 5H), $6.02(\mathrm{~s}, 1 \mathrm{H}), 4.18(\mathrm{~s}, 2 \mathrm{H}), 3.76(\mathrm{~s}$, $3 \mathrm{H}), 3.35$ (q, $J=7.1 \mathrm{~Hz}, 2 \mathrm{H}), 0.86(\mathrm{t}, J=7.1 \mathrm{~Hz}, 3 \mathrm{H}) ;{ }^{13} \mathrm{C} \mathrm{NMR}\left(100 \mathrm{MHz}, \mathrm{CDCl}_{3}\right) \delta 170.5,167.2,133.7$, $129.5,128.9,61.9,52.4,41.3,40.7,15.2$; IR (neat) 2981, 2952, 1749, 1660, 1443, 1246, 1199, 1115, 1017, 775, 738, $701 \mathrm{~cm}^{-1}$; HRMS (EI): Calcd for $\mathrm{C}_{12} \mathrm{H}_{13} \mathrm{CINO}_{2}\left(\mathrm{M}-\mathrm{CH}_{3} \mathrm{O}\right)^{+} 238.0635$ found 238.0626. 
All calculations were performed with the Gaussian 03 package. ${ }^{16}$ Geometries were fully optimized and characterized by frequency calculation using B3LYP/6-31G*. The energy differences between $(E)$ - and $(Z)$-isomers led to theoretical abundance using Boltzmann distribution (equation below). Images were generated using Chem3D.

$$
\begin{aligned}
& \mathrm{K}^{-1}=\exp \left(\frac{\Delta \mathrm{E}}{1.987 \times 10^{-3} \times \mathrm{T}}\right) \\
& \mathrm{T}: \text { temperature }(\mathrm{K}) \\
& \Delta \mathrm{E} \text { : energy difference }(\mathrm{kcal} / \mathrm{mol})
\end{aligned}
$$


[Table S7] a Comparative Study of the Optimized Structures of (E)- and (Z)$N$-Trimethylsilyl $\alpha$-Iminoesters

Optimization by B3LYP/6-31G*

\begin{tabular}{|c|c|c|c|c|c|c|}
\hline Compound & $\begin{array}{c}\text { Optimized Energy } \\
\text { (Hartree) }\end{array}$ & $\begin{array}{c}\text { Stability } \\
E\end{array}$ & $\begin{array}{l}\text { (kca } \\
\mathrm{vs}\end{array}$ & $\begin{array}{l}\mathrm{al} / \mathrm{mol}) \\
Z\end{array}$ & $\begin{array}{c}\text { Theoretical Value } \\
E: Z\left(25^{\circ} \mathrm{C}\right)\end{array}$ & $\begin{array}{c}\text { Measured Value } \\
d r\end{array}$ \\
\hline $1 a$ & $\begin{array}{l}(E):-1001.57111694 \\
(Z):-1001.57756041\end{array}$ & 0.00 & vS & -4.04 & $0: 100$ & $0: 100$ \\
\hline $1 b$ & $\begin{array}{l}\text { (E): }-962.252040472 \\
(Z):-962.258473604\end{array}$ & 0.00 & vs & -4.04 & $0: 100$ & $0: 100$ \\
\hline 1c & $\begin{array}{l}(E):-1040.88968386 \\
(Z):-1040.89592029\end{array}$ & 0.00 & vs & -3.91 & $0: 100$ & $0: 100$ \\
\hline $1 d$ & $\begin{array}{l}(E):-1080.20287125 \\
(Z):-1080.20882915\end{array}$ & 0.00 & vs & -3.74 & $0: 100$ & $0: 100$ \\
\hline $1 e$ & $\begin{array}{l}(E):-1157.62631840 \\
(Z):-1157.63266244\end{array}$ & 0.00 & vs & -3.98 & $0: 100$ & $0: 100$ \\
\hline $1 f$ & $\begin{array}{l}\text { (E): }-1119.52138492 \\
\text { (Z): }-1119.52744423\end{array}$ & 0.00 & vs & -3.80 & $0: 100$ & $0: 100$ \\
\hline $1 g$ & $\begin{array}{l}\text { (E): }-1119.52100772 \\
(Z):-1119.52687900\end{array}$ & 0.00 & vs & -3.68 & $0: 100$ & $0: 100$ \\
\hline $1 \mathrm{~h}$ & $\begin{array}{l}(E):-1119.51905884 \\
(Z):-1119.52228813\end{array}$ & 0.00 & vs & -2.03 & $3: 97$ & $0: 100$ \\
\hline $1 \mathbf{i}$ & $\begin{array}{l}\text { (E): }-1194.72695193 \\
(Z):-1194.73318600\end{array}$ & 0.00 & vs & -3.91 & $0: 100$ & $0: 100$ \\
\hline $1 \mathbf{j}$ & $\begin{array}{l}(E):-1539.79880037 \\
(Z):-1539.80513210\end{array}$ & 0.00 & vs & -3.97 & $0: 100$ & $0: 100$ \\
\hline $1 k$ & $\begin{array}{l}(E):-3651.30753421 \\
(Z):-3651.31379308\end{array}$ & 0.00 & vs & -3.93 & $0: 100$ & $0: 100$ \\
\hline 11 & $\begin{array}{l}(E):-3651.30492718 \\
(Z):-3651.31360729\end{array}$ & 0.00 & vs & -5.45 & $0: 100$ & $0: 100$ \\
\hline $1 \mathrm{~m}$ & $\begin{array}{l}(E):-1539.79566227 \\
(Z):-1539.80004149\end{array}$ & 0.00 & vs & -2.75 & $1: 99$ & $0: 100$ \\
\hline 1n & $\begin{array}{l}(E):-1172.44543647 \\
(Z):-1172.45184094\end{array}$ & 0.00 & vs & -4.02 & $0: 100$ & $0: 100$ \\
\hline 10 & $\begin{array}{l}\text { (E): }-1400.96748780 \\
(Z):-1400.95650364\end{array}$ & -6.89 & vs & 0.00 & $100: 0$ & $100: 0$ \\
\hline $1 p$ & $\begin{array}{l}\text { (E): }-1077.98198572 \\
(Z):-1077.98640239\end{array}$ & 0.00 & vs & -2.77 & $1: 99$ & $0: 100$ \\
\hline $1 q$ & $\begin{array}{l}(E):-1461.16706700 \\
(Z):-1461.17382842\end{array}$ & 0.00 & vs & -4.24 & $0: 100$ & $0: 100$ \\
\hline $1 r$ & $\begin{array}{l}(E):-1116.09528083 \\
(Z):-1116.10211271\end{array}$ & 0.00 & vs & -4.29 & $0: 100$ & $0: 100$ \\
\hline $1 s$ & $\begin{array}{l}(E):-1155.21206575 \\
(Z):-1155.21543998\end{array}$ & 0.00 & vs & -2.12 & $3: 97$ & $0: 100$ \\
\hline
\end{tabular}


Compound (E)-1a

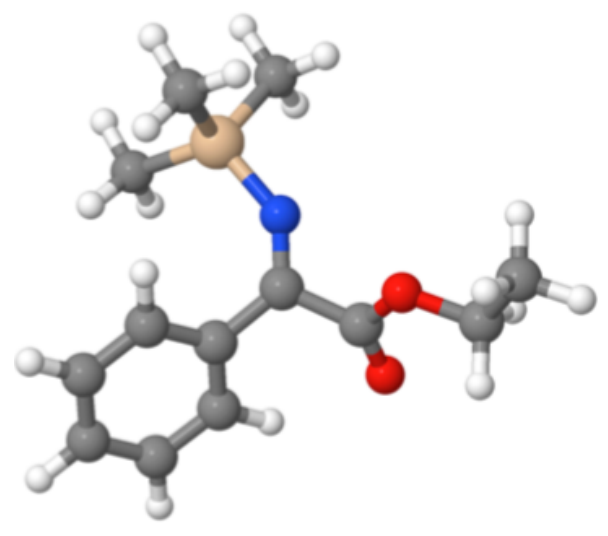

\begin{abstract}
$\begin{array}{llll}\text { Atom } & \underline{\mathbf{X}} & \underline{\mathbf{Y}} & \underline{\mathbf{Z}}\end{array}$
\end{abstract}
C - $-4.3949200018-0.06642709220 .0016226597$

C - $4.0959859802-1.3507899649-0.4580412517$

C $-5.1262909317-2.1912314798-0.8839238149$

C $-6.4510030532-1.7559845404-0.8556887044$

C $-6.7627926945-0.4747732233-0.3703128858$

C -5.71892902480 .36556760260 .0494852828$

C $-8.16934547440 .0376215728-0.3097270078$

C $-9.0428320459-0.2471832515-1.5333684116$

O $-9.1913433679-1.35351642-2.0151751784$

O $-9.65033348670 .8589274219-1.9820391195$

C - $10.55821581770 .6724419253-3.0953577156$

C - $11.09603251972 .038844296-3.4743603524$

N -8.72180088920 .67215906230 .6397681424$

Si -8.4188398541 1.1069205105 2.3164660892

C - 10.07588665690 .85222701493 .1826113618

C - 7.107650150 .08667788713 .225533752

C -7.96709295762.94280937732.3232732155

H -3.5972177168 0.60079391190.3170700836
H -3.0644626681 - $1.6912125176-0.4913621361$

H -4.8987978274 -3.1906058729 -1.2451345711

H -7.2493198487 -2.4013864929 -1.2019344325

H -5.9498455207 1.37128432850 .3884173439

H - $10.01382518260 .1981879372-3.9183525785$

H -11.3538556388 -0.0126466393 -2.7855039884

H -11.7954431798 $1.9426552731-4.3120902572$

H -11.6247291619 2.4969871479-2.6326690205

H - 10.28461344212 .708195459 -3.77747702241

H -10.0223148177 1.1460640986 4.2383508973

H -10.8612032972 1.44628979822 .7025015423

H -10.3866391969 -0.1986789305 3.1465362106

H -7.1307893043 0.32502062594.2970149183

H -6.0928868499 0.27228223472 .8608213223

H -7.3015283736 -0.9879316652 3.1254585052

H -8.70932434313.5296430417 1.7710264163

H -7.9347991671 3.32433417373 .3514335448

H -6.9867525569 3.13170938951 .8704673626 
Compound (Z)-1a

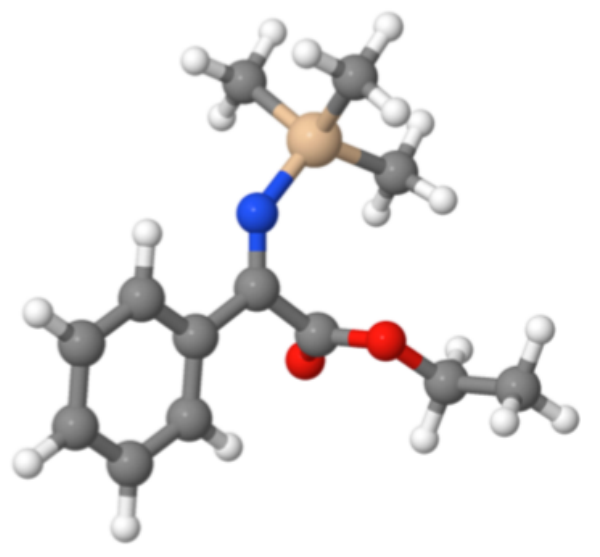

$\begin{array}{llll}\underline{\text { Atom }} & \underline{\mathbf{X}} & \underline{\mathbf{Y}} & \underline{\mathbf{Z}}\end{array}$

C -3.1598921131-0.6248108937-0.5353780397

C - 2.47851010860 .19117666550 .368079668

C -3.19059192970.8895513888 1.3491922725

C - 4.57418458710 .77307098341 .4239264363

C -5.2698053405-0.0409366627 0.5149574526

C - $4.5482434438-0.7401700348-0.4649148072$

C - $6.7537296173-0.1336966010 .6110628096$

C - $7.4517371529-0.8834436065-0.5245337933$

O -7.5221807283-2.0920609053-0.6013170914

O -7.9946011255-0.0290836024-1.4104510874

C -8.6996205733 - $0.6313866442-2.5274273653$

C -9.13799520820.4922161661 -3.4465201021

N -7.39997568120.35882641271.5888914997

Si -9.08381306890.4328974609 2.091457239

C -9.130062243 -0.4045625824 3.7818226615

C -9.4891105942 2.27010779612.2394972365

C - $10.3457095419-0.40161356830 .9495309212$

H -2.6114156111 -1.1761874009 -1.2941953408
H -1.39705691370.28284583180.3108435422

H -2.6627708856 1.5257877482 .0547047474

H -5.1448828698 1.3049899022 .1780429777

H -5.065931015 -1.394900593 -1.1590800832

H -8.0261370033 -1.3356516062 -3.0254412229

H -9.5481436852 -1.2008613518 - 2.1359980873

H -9.6736160623 $0.0780499011-4.3076770856$

H -9.8061990598 1.1865643649 -2.9270391667

H -8.27480003 1.0554464216 -3.8148374839

H -10.1288793626 -0.3312285386 4.2297622829

H -8.8774461975 -1.4685031395 3.7042986321

H -8.41468040520.058788415 4.469967435

H -10.50875594352.41712380472.6167080027

H -9.4176464644 2.77351099021 .2682791781

H -8.79898809362.77113563972.9271536084

H - $10.077416453-1.4408127980 .7268446717$

H -11.3315170425 -0.4120011334 1.4319494439

H -10.4488508446 $0.1333667703-0.0009399621$ 
Compound (E)-1b

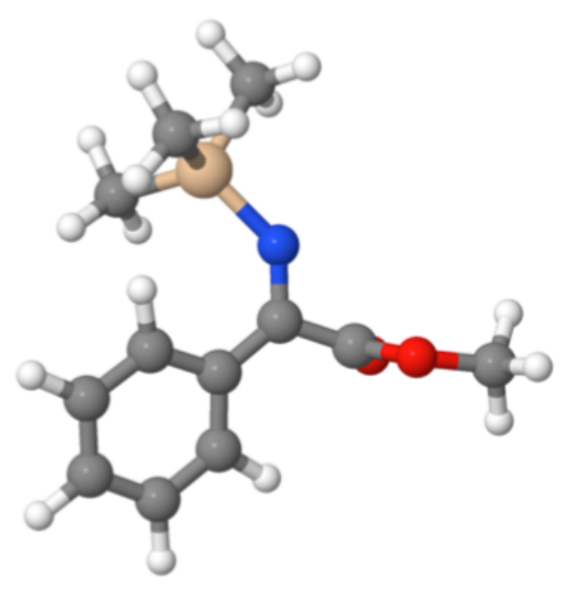

$\begin{array}{llll}\text { Atom } & \underline{\mathbf{X}} & \underline{\mathbf{Y}} & \underline{\mathbf{Z}}\end{array}$

C - $4.4569627454-0.1579088056-0.5469298378$

C -4.1789323058 - $1.4335916138-1.0425052608$

C -5.2262321572 -2.2618269501-1.4504357009

C - $6.5475966036-1.822926251-1.369074048$

C - $6.8375621657-0.550844948-0.847777627$

C - $5.77690776510 .2772052265-0.4457380192$

C $-8.238443416-0.0333424797-0.7268634589$

C -9.152425307 - $0.2800904668-1.9285659735$

O -9.3056022998 -1.3647324931-2.4548968557

O -9.7924369605 $0.8355607914-2.3076886118$

C -10.7254941963 $0.6685613871-3.3894271838$

N -8.75493112110.5784207951 0.2569194688

Si -8.39504365670.9695420008 1.933436888

C - 10.03002026280 .7213258762 .8420002862

C -7.0758061521 -0.09360942392.77810978

C -7.9110033229 2.79693399561.9688978885

H -3.6463745207 $0.4998852111-0.2448482157$
H -3.150528402 -1.7768038653 -1.117537924

H -5.0148961032 -3.2543118418 -1.8393747601

H - $7.3595024743-2.4580132864-1.702383077$

H -5.992154089 $1.2768648808-0.0797258914$

H - 11.11818736981 .6654858242 -3.5898362611

H -10.2226421756 $0.2655188762-4.2725933459$

H -11.5307910391 -0.0104490705 -3.0969893961

H -9.9374151601 0.97658990533 .9050161313

H -10.8159378399 1.34865614482 .407351854

H - $10.3654067266-0.32073131632 .7793423985$

H - 7.03688170470 .14767359683 .8484977667

H -6.0750979696 0.05670957562 .3622912315

H -7.3115294239 -1.1611093962 2.6922916536

H -8.6560031996 3.40842226411 .4480794084

H -7.8469676896 3.15486070043 .0040285147

H -6.9387076742 2.97896515681.4964761785 


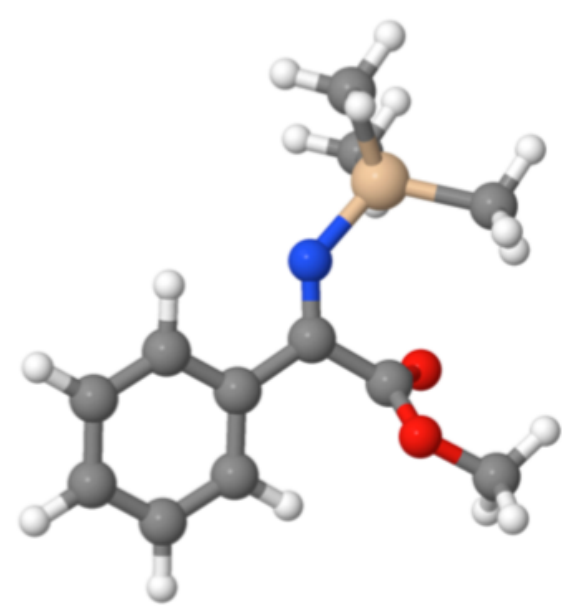

$\underline{\text { Atom }} \underline{\underline{X}} \quad \underline{\mathbf{Y}} \quad \underline{\mathbf{Z}}$

C - $2.8080106395-1.207129462-0.6725834171$

C - $2.2168413865-0.85725067670 .5415646796$

C - $2.9950498636-0.28566627931 .5537079217$

C $-4.3535988891-0.06908127381 .3520455519$

C -4.9583231253 -0.41133518 0.1310219089

C -4.1691028472 -0.9827830267 -0.8790516964

C -6.4246159008-0.194384706-0.0322278555

C -7.0341982003 -0.4385172046-1.4161197119

O -7.9286801121-1.2278228937-1.6339685124

O -6.50434225480.3755671663 -2.3497760074

C - $7.08658095790 .2740764511-3.6641115345$

N -7.1618942948 0.15353588940.942920996

Si -8.8862124376 0.4550500361 1.1765569417

C - 8.96801885131 .73676100342 .5594264431

C -9.7985175833 $1.1417090682-0.3349211655$

C -9.6468231659-1.179513517 1.7330737162

H - 2.2102310529 -1.6545583323 -1.4619890289
H -1.155377831 -1.0284144085 0.7002238552 H - $2.5389464581-0.0108841262 .5011091379$

H -4.9759983478 0.36439566322 .1277796536

H -4.6117769554-1.253844308 -1.8320048292

H -6.5370942807 $0.9854913019-4.2804278731$

H -6.9780335384 - $0.741300745-4.0536301461$

H -8.1480539211 0.5320044999 -3.6296089857

H -10.0068338415 1.96656500782 .8272156449

H -8.4585704413 1.3747321613 .4595347167

H -8.4871511428 2.67630313962.2616894155

H -10.80421025 $1.4703316704-0.0431765121$

H -9.9038943048 $0.3911932715-1.123845069$

H -9.2825657938 2.0133839378-0.7567039293

H -9.1275485761 -1.5810123502 2.6104122816

H -10.7036449802 -1.049609076 1.99730166

H -9.5841957741 -1.9231267020.9313397496 


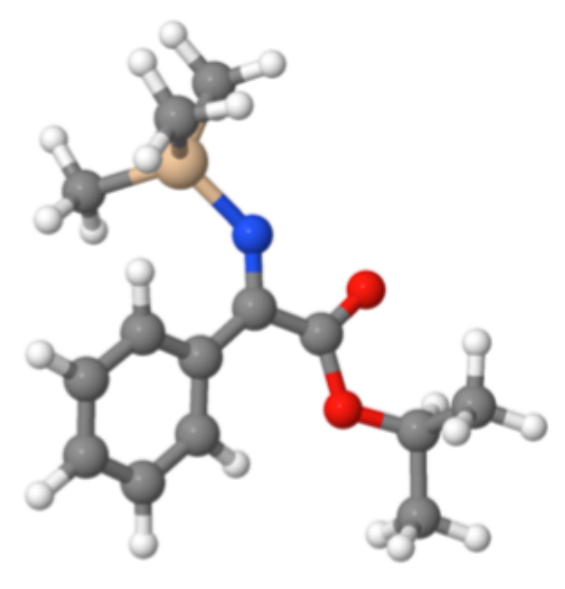

$\underline{\text { Atom }} \underline{\underline{X}} \quad \underline{\mathbf{Y}} \quad \underline{\mathbf{Z}}$

C - $-3.726047615-0.86292482330 .734771695$

C $-3.5495389473-2.23891947340 .5745700232$

C -4.6245168781-3.0326949228 0.1700186156

C -5.8721719339-2.4605503871-0.0773500907

C -6.06484341 -1.0810495003 0.1068010132

C -4.9758439352 -0.28996691530.5071894285

C -7.386161713 -0.4175435574-0.1355838366

C - $8.128068849-0.8398759327-1.405874843$

O -8.3674754882 -1.9997173721 -1.6847426397

O $-8.50052827960 .2176805608-2.1369335103$

C -9.2802113392 -0.0464969255 -3.3447222374

N -7.96415482350.44499992960.5931701032

Si -7.8212958281 1.15837064932 .1936035569

C - 9.59285858821 .24758095812 .8374839436

C - 6.77784551350 .20056718963 .4507937235

C -7.13757790562.9035156541 1.9459238476

C - $10.751491678-0.1902923502-2.9705907128$

C -8.9982746608 $1.1186340331-4.2822615253$

H -2.8898354618 -0.23527180061.0311394059

H - 2.5769123945 -2.6883588647 0.7564001911
H -4.4916108694 -4.1035423705 0.041074146 H -6.7024284036 -3.0730742392 -0.4078994166 H -5.1083902056 0.7829370529 0.6131289845 H -8.9127314039 -0.9850757149 -3.7701750206 H -9.6340250009 1.72692062013 .823536024 H -10.2280531913 1.82028986912 .1528994963 H -10.0304862625 0.2471308827 2.9368875736 H -6.89439088180.6483649849 4.4464498339 H -5.71145155930.1964070878 3.2057066582 H -7.1027293752 -0.8443169644 3.5222131345 H -7.7274816931 3.45345987341 .2044754431 H -7.1728188278 3.46527271762 .8876453117 H -6.09562238852.8954373789 1.6052832613 H -11.3522528292 -0.3630312803 -3.8708286518 H -10.8961059178 -1.0376541873 -2.2949583692 H - $11.11419271420 .7197834122-2.4805487722$ H -9.5338944195 $0.9766251904-5.2272150562$ H -7.928199269 1.1939217305 -4.4996106586 H -9.3276585449 2.0635728069 -3.8367520732 


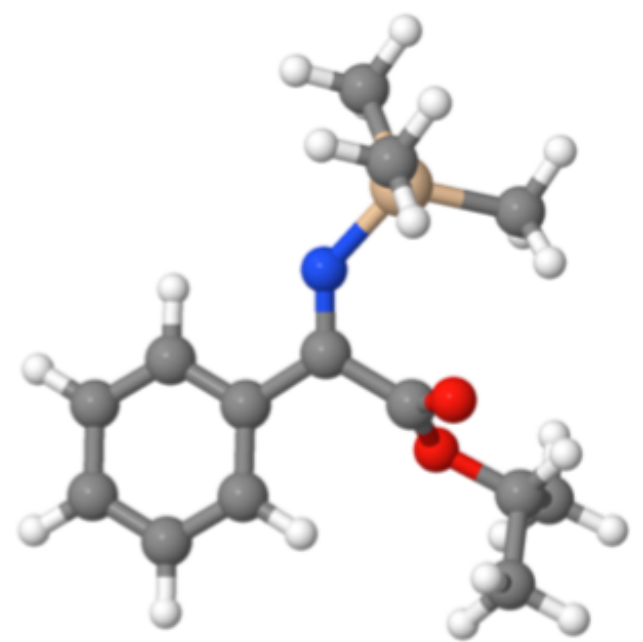

$\begin{array}{llll}\text { Atom } & \underline{\mathbf{X}} & \underline{\mathbf{Y}} & \underline{\mathbf{Z}}\end{array}$

C -3.001113559-0.5389171238 -0.3473444303

C - $2.3709536551-0.47253792380 .8954256267$

C -3.1356009644-0.2897538769 2.0523644685

C - $4.5182724528-0.17254056261 .964481767$

C -5.1643672664 -0.2443843872 0.718941836

C -4.3888777872 -0.4292177154-0.4359930595

C -6.6461242736-0.08068873930.6657244697

C - $7.3457188415-0.2941002617-0.6817651487$

O $-8.01738996890 .5569659259-1.2284660186$

O -7.1803575878 -1.5501422362 -1.1331981799

C -7.8969323996 -1.9318281399 -2.3527168389

N -7.31649285120.2534715851.692851381

Si -9.01318969710.59908819672.0351333538

C -9.24804719540.11871098773.8453093092

C -9.23691381392.4577236515 1.7994502084

C -10.267256288-0.3645399334 0.992574921

C -7.0961001189-1.4927536397-3.5738947555

C -8.0954017596-3.4376543779 -2.2602268622

H -2.4132147414 -0.6772826871 -1.2507021155

H - $1.2899859223-0.56203821330 .9640712024$
H - $2.6496285766-0.23748800273 .0230679598$

H -5.1278007991 -0.0217400323 2.849223933 H -4.8634201737 -0.4898007607 -1.4096953688 H -8.8586918646 -1.4114808674 -2.3369528136 H -10.2667046138 0.34093365634.1868434746 H -9.0736826304 -0.9530794412 3.9987303193 H -8.5487708903 0.66336029164 .4896098995 H -10.2482969562 2.77211137632.0855245483 H -9.0784237033 2.72983742770.7503643677 H -8.5233350953 3.02341319552 .4088490126 H - 10.0666878375 -1.4430720025 1.0112018157 H - $11.2762522817-0.21551327771 .3979733126$ H -10.2702037138 -0.0347657551-0.050459757 H -7.6224832176 -1.7837732253 -4.489939103 H -6.9709908963 -0.4065183052 -3.5839113477 H -6.1090717329 -1.9688718427 -3.5808308287 H -8.6542232199 -3.7950284892 -3.1319772618 H -8.6559913764 -3.7018871931 -1.3582915698 H -7.1308922766 -3.9560002808 -2.231818727 
Compound $(E)-\mathbf{1 d}$

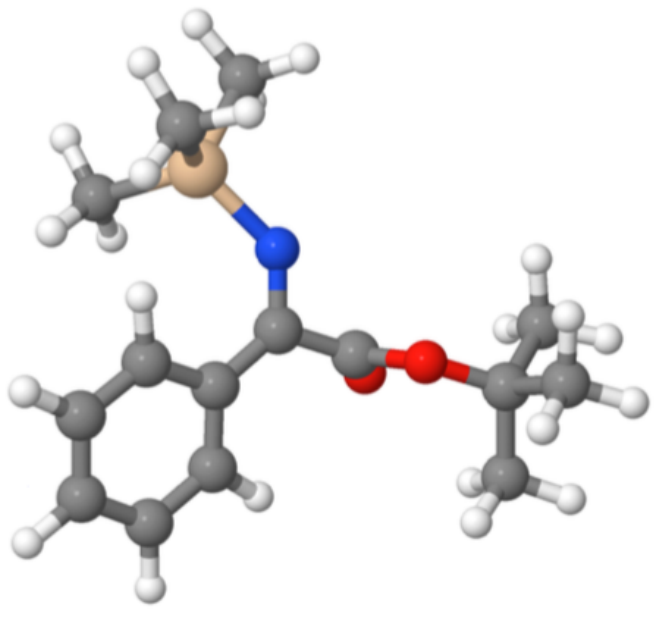

Atom $\underline{\underline{X}} \quad \underline{\mathbf{Y}} \quad \underline{\mathbf{Z}}$

C $2.7592000896-0.2472107960 .5685069504$

C $3.1022418866-1.5459463740 .186507558$

C $2.1263612381-2.3928149768-0.3425302816$

C $0.8127144397-1.9495176411-0.4939049431$

C $0.4536110769-0.6530123265-0.0881731529$

C 1.44387474860 .19350666520 .4362301801

C -0.9439602704-0.1323303177-0.2278820913

C -1.6639287193 -0.4778090059-1.5362956018

N -1.60654589110.54849147120.6125212254

O -2.0706505806 $0.6268003042-2.1652147181$

O -1.8469014647-1.6262957114-1.896193418

C - $2.88442323260 .5692893307-3.4007578148$

C -3.1127105543 2.0496466614-3.7126908357

C - $2.086696363-0.110375923-4.5180349937$

C -4.2109456486-0.1397221564-3.111795714

Si -1.5266255609 1.06662855922 .2889934039

C -3.28913812830.87422694772.9351611201

C - 0.36915767470 .08245560653 .4199287797

C - 1.04632364142 .89563524192 .268521236

H 3.51694210170 .42443514270 .9631987087

H $4.1265796289-1.89284625540 .2934353746$
H $2.3884515264-3.4036781283-0.6433543636$ H $0.0566652429-2.6009267305-0.916190651$ H 1.18264863231 .21074614120 .7125274368 H -3.71899132 2.1535847773 -4.6188073302 H -3.6343127999 2.5412304486 -2.8854887673 H - $2.15907870322 .5630721313-3.8721541268$ H -2.6437177331 -0.0402368103-5.4592155799 H - $1.9093213758-1.1632223824-4.2933145476$ H - $1.1222064570 .3902895867-4.6564808766$ H -4.7164316955 $0.3322221016-2.2626213378$ H -4.8655662201 -0.0589930527-3.9869813956 H - 4.0557192098 -1.1963606427 -2.8877404914 H -3.3716781828 1.21050807763 .9762518872 H -3.9911843893 1.45918122922 .3308678318 H -3.6130311469 -0.1726776595 2.8982179565 H -0.519927094 0.39208562244 .4624802444 H 0.68824132160 .22316300023 .1764682217 H -0.5794428956 -0.9923663615 3.3648063036 H - 1.6908593 .46133136651 .5867424287 H -1.1530242463 3.33080539513.2700167655 H - 0.0081117343 .04874944391 .9515314197 


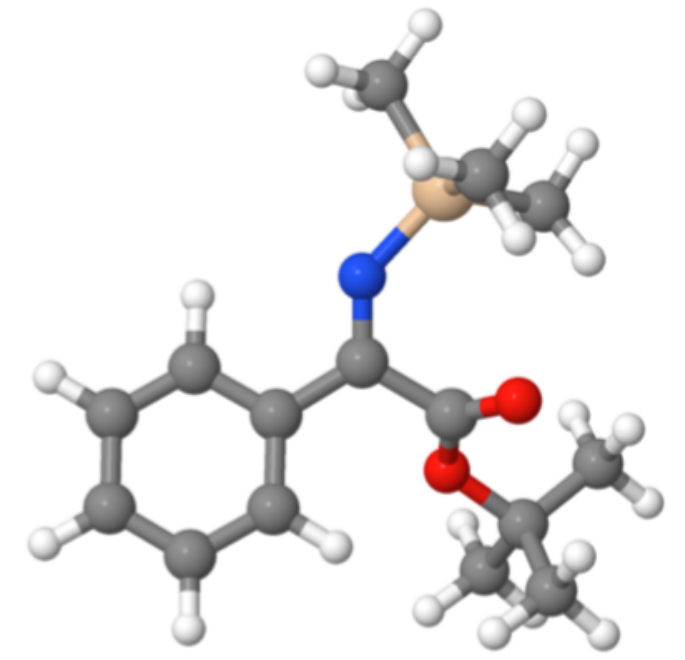

$\begin{array}{llll}\text { Atom } & \underline{\mathbf{X}} & \underline{\mathbf{Y}} & \underline{\mathbf{Z}}\end{array}$

C $1.213884803-1.556375901-0.1307093511$

C $1.5372095248-2.19527431711 .0666925392$

C $0.6660846779-2.10637700772 .1569153431$

C -0.5162169139-1.3815887066 2.0490951386

C $-0.858885418-0.745002570 .8447128988$

C $0.0215357118-0.8416987766-0.2440499478$

C - 2.11508243720 .06195510640 .7901605762

C - $2.66350753610 .4695446893-0.5885883067$

N -2.70941657020.42078315381.8537455109

O -2.7377902821 -0.5861765143-1.4113844597

O -3.0228776769 $1.6023039918-0.8418628252$

C -3.2889297218 -0.4860213707-2.7853118015

C -3.1685343584-1.9242462784-3.2929410616

C -4.7543196535 -0.0456616022 -2.7291826706

C - $2.42790600710 .4665270702-3.6204008075$

Si -4.1145027503 1.40183628482 .2761726794

C -3.5292061573.19397555262.3557771612

C -5.6050638075 1.22079286221 .1227734913

C -4.62117470740.7959380396 3.9915289999

H 1.8896813589 -1.6142482347 -0.97979496

H $2.4627770012-2.75862026281 .1517193925$
H 0.9125055249 -2.6019413854 3.0922882158 H -1.1963261163 -1.2891514571 2.8893346475 H -0.2169067015 -0.3539844089-1.1831392796 H -3.5408465153 -1.9912251024 -4.3206845655 H - $2.1250373348-2.2544382164-3.2787695041$ H -3.7528841968 -2.6057595267 -2.6666962661 H -5.1947551396 -0.1235243033 -3.7295764514 H -4.8467399603 $0.9860448146-2.3868712842$ H -5.3234471626 -0.6956556339-2.0562731824 H - 1.38131063750 .1423312647 -3.6182507788 H - $2.77983097950 .4587417593-4.6581614874$ H -2.4847090211 1.4883415315 -3.241375097 H -4.3292878788 3.85113714832 .7185791779 H -2.6738238915 3.30202078 3.0321443767 H -3.224679052 3.53848360051 .3621691277 H -6.4824971931.7023318278 1.5732849161 H -5.8625642928 0.16704336590.958568098 H -5.4252018996 1.68476903390 .1492443667 H -3.79169092340.8899570009 4.7015484988 H -5.4689557928 1.3715252624 .3837621592 H -4.9197009159 -0.2592075635 3.9694967727 


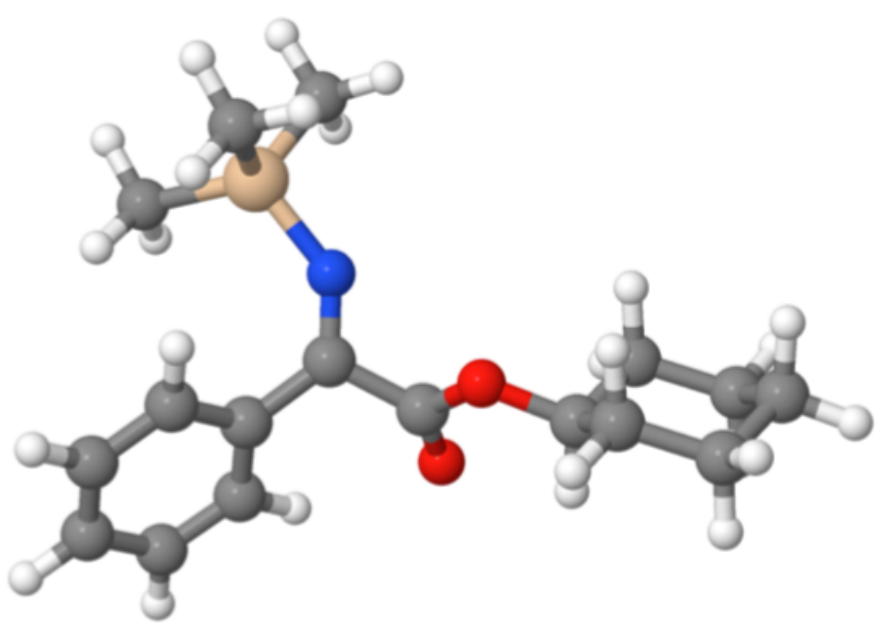

$\begin{array}{llll}\underline{\text { Atom }} & \underline{\mathbf{X}} & \underline{\mathbf{Y}} & \underline{\mathbf{Z}}\end{array}$

C $3.81711117-0.59362184181 .1983412522$

C $4.0045428958-1.94933942370 .9205587354$

C $2.9576339992-2.69626758750 .3770482423$

C $1.7272189737-2.0973060850 .107834004$

C $1.5221783235-0.7403903050 .4090762118$

C 2.5833265330 .00431459720 .9487197027

C $0.2173562542-0.05167593690 .1488188622$

C - $0.4472323387-0.3551986188-1.1955168597$

N -0.40574815190.74281309660.9166926789

O -0.7488159869 $0.7649839545-1.8639755123$

O -0.6919687074 -1.4841251566 -1.5771739843

C - $-1.461719270 .6167788307-3.1264911038$

Si -0.3682956615 1.30375938162 .5820095413

C - 2.17724911621 .33073317353 .1185966725

C 0.60099730980 .23348618553 .807729445

C 0.3192907093 .06431908632 .542480202

C -1.0953496692 $1.8247701279-3.9849490471$

C - $1.87374959731 .8038086354-5.3114788583$

C -3.3898340756 1.7151994667-5.0756588921

C -3.7468333675 $0.508993761-4.1933756802$

C - $2.96705117250 .5291750174-2.8677021807$

H $4.6327134349-0.0007574891 .6037351794$

H 4.9643910052 -2.4186854168 1.1192413169
H $3.0993814288-3.75088949050 .1563429444$ H $0.9190839007-2.6719506375-0.3288533214$ H 2.44329407581 .0631709971 .146425436 H -1.1143513893 -0.3092808371 -3.597074694 H -2.282494394 1.70432232894.1448059171 H - 2.77026623841 .97354041262 .4588412564 H -2.6162075258 0.3265235054 3.084773134 H 0.43402062860 .59759269884 .8299878997 H 1.67892900210 .23903011593 .6195574657 H $0.2667380326-0.81034439743 .773674831$ H -0.2238161368 3.68078293261 .8177901546 H 0.2191610633 .53645089263 .5277444938 H 1.38140556743 .08729350252 .2719484625 H - 1.33537250232 .7389431452 -3.4250658041 H -0.014006485 $1.8351994285-4.1664034558$ H - $1.62794544272 .6976343068-5.8977023243$ H - $1.54917882150 .9403213183-5.91051174$ H -3.7336991211 2.6372645109 -4.5844071251 H -3.9190813014 $1.6547086466-6.0348720338$ H -4.8240448697 $0.4888822101-3.9879593661$ H -3.5170515747 - $0.4195476561-4.73619348$ H -3.2666216109 $1.4000334773-2.2688223915$ H -3.184437779 -0.3661468649-2.2756601869 


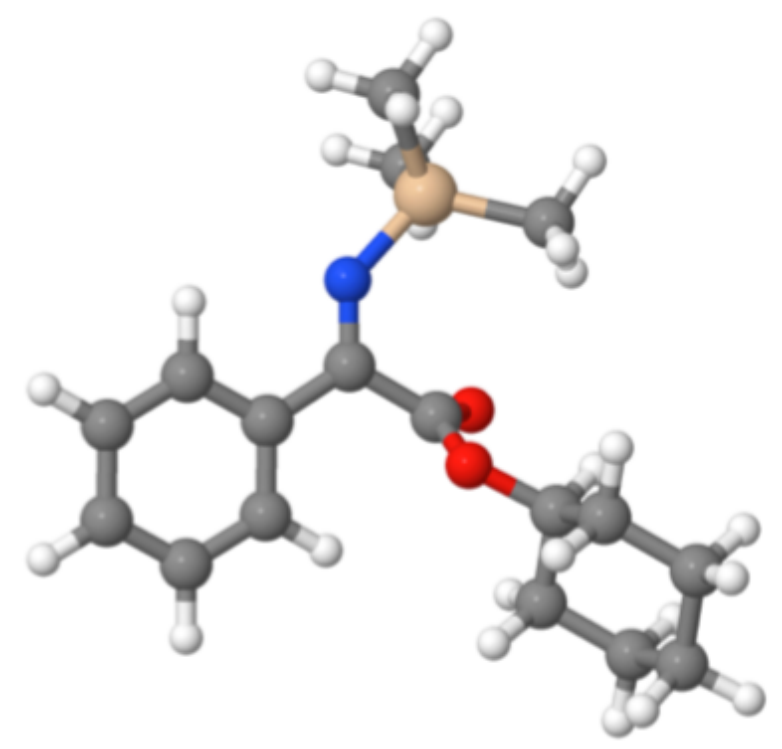

$\underline{\text { Atom }} \underline{\underline{\mathbf{X}}} \quad \underline{\mathbf{Y}} \quad \underline{\mathbf{Z}}$

C $2.9932225582-0.0864318565-0.0415396378$

C 3.63508580670 .16208626561 .1718493236

C 2.87713631920 .36076569482 .3306836894

C 1.48885087250 .30895649472 .2747115472

C 0.83172970350 .06508739111 .0571783792

C $1.6002789676-0.1317541568-0.1003227658$

C -0.6571932066-0.0117762325 1.0426466809

C - $1.3499033938-0.1742740826-0.3147640629$

N-1.33861912420.02293158542.1153609019

O -1.1710287381 $0.9083261437-1.0934189168$

O -2.0250165281-1.1393178208-0.6087175921

C - $1.87954533640 .9470220671-2.3704436861$

Si -3.0502050646 -0.0835486782 2.5272112282

C -3.2525755089 1.0224538524 .0434457508

C - 4.2556318180 .50449752711 .1890278678

C -3.3783386623 -1.88887140942.967296723

C - $1.04772572630 .2653891671-3.458450533$

C - $1.72597708650 .4136107498-4.831663487$

C - $2.00578687891 .8869132418-5.1664844241$

C - $2.82231199452 .5659350028-4.0558405337$

C - $2.1429210132 .4176802986-2.6838413575$

H $3.5759134454-0.2446818891-0.9449923719$

H 4.72033239170 .2006374161 .2165530883
H 3.37291399350 .55467284243 .2782124685 H 0.88354874320 .45261730233 .1635721432 H $1.1157279894-0.3202642232-1.0528359694$ H - $2.8220798030 .4061806598-2.2379579457$ H -4.2791751227 0.9841389194 4.428629204 H - 2.57716962430 .7116352924 .8483793323 H -3.0264618622 2.06903477643.8064292557 H -4.281676277-0.1799471456 0.3359673518 H -3.9939075554 1.50356127060 .818649942 H -5.2693032850.5675178992 1.605054726 H -3.2291347176 -2.5318260971 2.0929389298 H - $2.7043176689-2.23228344393 .7598657144$ H -4.4088315097 -2.0254068716 3.3181224175 H -0.0537286159 0.7336734297-3.4828542847 H -0.9107612646 -0.7921312413 -3.2072330283 H - $1.0969253929-0.0437134507-5.6048825911$ H -2.6726638195 -0.1457283764-4.8304904616 H - $1.05102034722 .4187121572-5.290662912$ H -2.5338378553 $1.963626615-6.1250356965$ H -2.9688575129 $3.6289534851-4.2819118269$ H -3.8246418294 2.1152409458 -4.0152497459 H - $1.18504653782 .9554400099-2.6798639262$ H - $2.76070710952 .8581994733-1.8924369083$ 


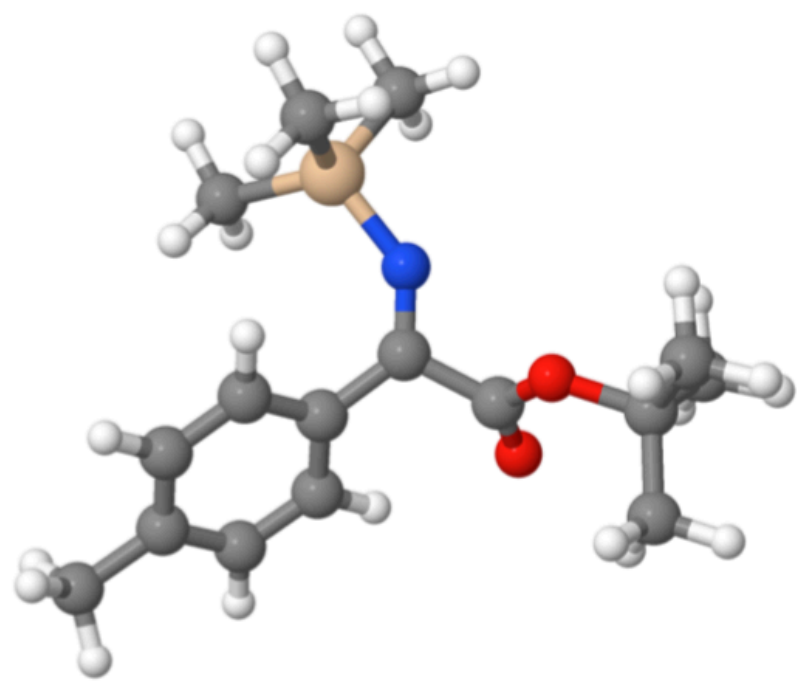

Atom $\underline{\mathbf{X}} \quad \underline{\mathbf{Y}} \quad \underline{\mathbf{Z}}$

C 2.74331299170 .0818337510 .5158774562

C $3.1783303562-1.19331518230 .1314337395$

C $2.2304989147-2.0768588739-0.4033305331$

C $0.8948522001-1.7099487125-0.5482571149$

C $0.4587792201-0.4406343808-0.1320499702$

C 1.40639548480 .45136212330 .3929132232

C - $0.96386855630 .0034433402-0.2622499813$

C - $1.6714226531-0.3757091492-1.5680786608$

N -1.65714929070.6470592670.5836812003

O -2.1541446575 $0.7066455413-2.1826833629$

O -1.7826088137-1.5295383587-1.9400365985

C -2.9698294697 $0.6091310373-3.4134943999$

Si -1.59242859761.1607922186 2.2616784267

C -3.3352810570.8649605953 2.9230992619

C -0.37085045570 .24162005013 .3799619668$

C -1.22065706113.0152005991 2.2479135603

C -3.2974918372 2.074640866 -3.7070766671

C - $2.1360504399-0.0026599224-4.5438921608$

C - $4.2445815783-0.1898264147-3.12607191$

C $4.6201362764-1.60934493550 .3002321131$

H 3.46256371870 .79686153780 .9091045791

H 2.5449966275 -3.0697439428 -0.7176133995 H 0.179999519 -2.4026756661 -0.9766375306
H 1.09572775021 .45317480230 .6747962892 H -3.4251047769 1.18778829123 .9678616011 H -4.075132167 1.41517569662 .3313727363 H -3.6014776114 -0.1978680596 2.8802162712 H - 0.52572643630 .54465023674 .4238890613 H 0.67453823840 .43784337553 .1233735564 H - $0.5246125442-0.84291738193 .3282178288$ H -1.9010477498 3.54413233751 .5714490514 H -1.3482396393.4391994063 3.2517964405 H -0.1949406588 3.23128809821 .9268571252 H -3.9102998484 2.1488784274 -4.6117298881 H -3.8495213339 2.5204042652 -2.873719919 H -2.3803123722 2.6522994292 -3.8606923932 H - 2.7014265417 $0.0449464937-5.4815215492$ H - 1.8901235399 -1.0450480304 -4.3352636864 H - $1.20645521890 .5609002765-4.6795734652$ H -4.7745059413 0.2374740167 -2.2681707731 H -4.9090217502 -0.1422917944 -3.9963119221 H -4.0180660049 -1.2363538671 -2.915662838 H $5.2863217372-0.74132469340 .3397485292$ H $4.7624868812-2.17322876541 .2319308064$ H $4.9508916863-2.254761949-0.5208071001$ 


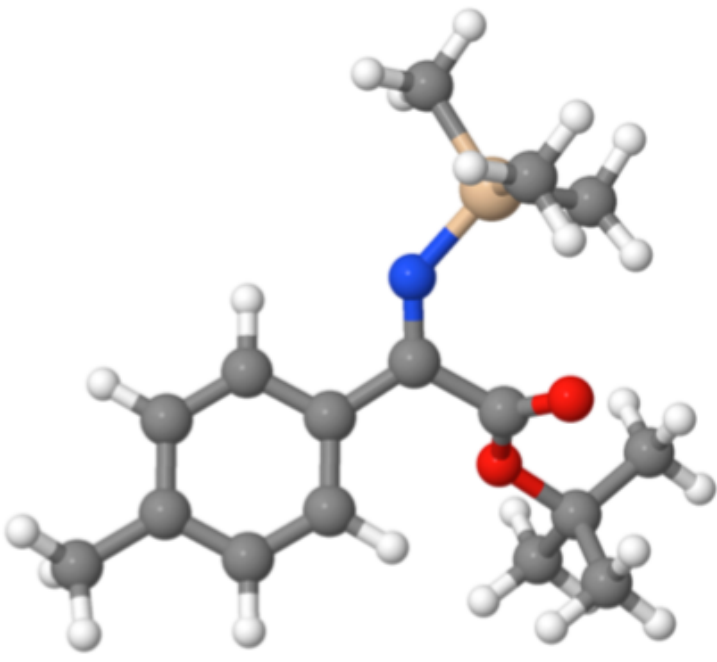

Atom $\underline{\mathrm{x}}$

$\underline{Y}$

$\underline{z}$

C $1.472377335-1.05312888462 .2501744893$

C $2.3818783042-1.10584013171 .1811896943$

C $1.9070795877-0.7974086149-0.09838902$

C $0.5704194658-0.4638761459-0.3118872394$

C - $0.3349061253-0.41432087790 .7578449993$

C $0.1430410051-0.70812294712 .0462184213$

C - $1.7581130482-0.00026906050 .5921909386$

C - $2.34947478510 .027599873-0.8279049201$

N -2.46431898650.3402138867 1.5924399701

O -2.1307769569-1.1319938969-1.4650853219

O -2.973964301 $0.97589485-1.260577676$

C - $2.6503609988-1.4005962959-2.8282061839$

Si -4.09292197030.957202771 1.8698758901

C -4.00962716892.8325269202 1.6744556129

C -5.4440526757 0.22171478520.7653777232

C -4.48195360930.49534154143.6591703899

C - $2.1521874789-2.8223545081-3.0948874288$

C -4.1806619045 -1.3485537246 -2.8233873076

C -2.0400076436 - $0.4079281193-3.8222989236$

C $3.8209795294-1.50208579081 .4082652044$

H 1.8174322278 -1.2831455681 3.2560710953

H $2.5929088603-0.8176762763-0.9423360182$ H $0.2404219653-0.2328763618-1.3190853149$
H - $0.5531066604-0.65293351472 .8766505314$

H -4.9691895873.2969177485 1.9338829228

H -3.2407101651 3.26575620312 .3239852941

H -3.7692379177 3.09535628480 .6391283974

H -6.4306323374 0.53622625521 .1296859725

H -5.4274857964 -0.8751290264 0.7814587459

H -5.3457501529 $0.5505167695-0.2727576797$

H -3.733430768 0.91180640724 .3427672754

H -5.46610109650.8720717043.9649112932

H -4.4868067447 -0.5927181497 3.7972610452

H -2.4673306269 -3.1493498587 -4.0914279218

H -1.0596576004 -2.8660112693 -3.0437836551

H - 2.558624895 -3.5195837722 - 2.3554259378

H -4.5582225416 -1.6945884023 -3.7922649713

H -4.5439716653 - $0.334464196-2.6504069364$

H -4.5841195705 -2.0074109782 -2.0472552373

H - $0.9457482231-0.4486590023-3.7856224467$

H - $2.352275242-0.6739081544-4.8385233747$

H - 2.36528567370 .6126838222 -3.613975491

H 4.2245683673 -1.0419313502 2.3173257936

H 3.9187485874 -2.5894578207 1.527871962

H 4.4564706821 -1.2063631223 0.567378344 


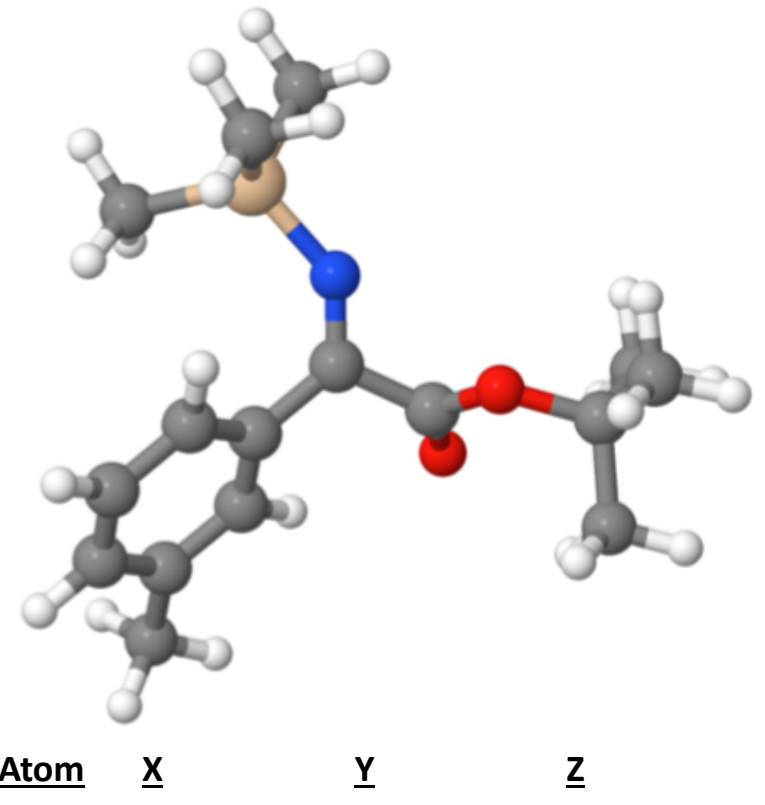

C $0.9894364715-0.47560629470 .9185275322$

C $1.1239111406-1.86198663080 .8433209352$

C $0.0224339661-2.67452035570 .5419677006$

C - $1.2149550449-2.06472594490 .3083995535$

C - $1.3703923175-0.6726528850 .4065229475$

C -0.25240589060 .1197415860 .7075038663$

C - $2.68778507-0.00227165840 .1639178497$

C $0.1622932392-4.17849110650 .4862665104$

C -3.4858102423 - $0.5050180775-1.0438487171$

O -3.8470481643 -1.6624787863-1.151197256

O $-3.73795452670 .4892011713-1.8982352441$

C - $4.57621246230 .2924993083-3.1022115922$

C - $4.58536791171 .6886121509-3.7283028872$

C -3.9141794413-0.7228123522-4.0391952252

C - $5.988247045-0.1283776056-2.6838397398$

N -3.2253289959 0.92309881250 .8455124154

Si -3.0014565982 1.74382895132.3837451701

C - 4.74401946461 .92745783783 .0854605184

C - 1.93486565660 .85027578423 .6688435639

C - 2.28659879183 .45006848931 .99184143

H 1.85716418560 .14270270711 .1331408794

H 2.0966188605 -2.319296367 1.0111752163

H - 2.0767682315 -2.6717034984 0.0529150347
H -0.35416563 1.20029499140 .7427649133 H $1.1230516602-4.47615763980 .0516019903$ H 0.1110565206 -4.619390613 1.4907517383 H -0.6359033545 -4.6317331877-0.1099631899 H -5.1895723943 $1.6865652476-4.6417994496$ H -5.00752836 2.4202106372 -3.0322934485 H -3.5688634849 $2.0039674971-3.9847270246$ H -4.4746507454 - $0.769934807-4.9797579619$ H -3.8932150816 -1.7187420664 -3.5940044484 H -2.8884335186 -0.415594498 -4.2706315502 H - $6.39961482080 .5874713155-1.9642698502$ H -6.6409669414 -0.1415448674 -3.564064486 H -5.989173194 -1.1221872594-2.2331544123 H -4.7350925528 2.4711739324 4.0384131725 H -5.3893954315 2.47249191742.3878371103 H -5.204445184 0.94888612143 .2663969763 H -1.996614961.3759954584.630782098 H - 0.88051766380 .7927837133 .3822742648 H - $2.2875290248-0.17492162153 .8332448267$ H -2.8820466644 3.95686392251 .2244267425 H -2.28878812814.0810210832 2.889441475 H -1.25303605393.3942354875 1.6307900519 


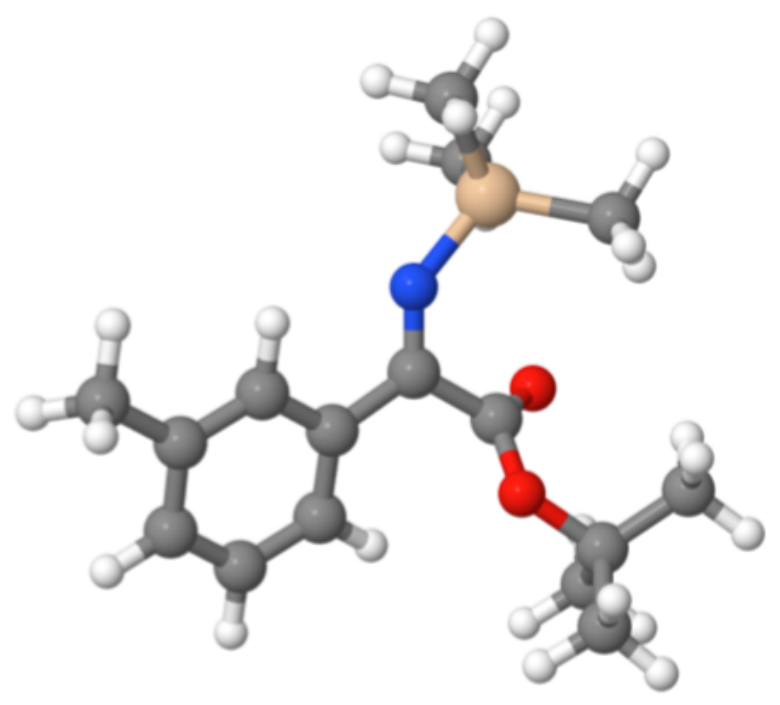

$\underline{\underline{A}} \underline{\underline{\mathbf{X}}} \quad \underline{\mathbf{Y}} \quad \underline{\mathbf{Z}}$

C $1.3575363469-0.7279345996-0.3803339716$

C $2.0858733965-0.29975027320 .7273344871$

C 1.44201075310 .30065057471 .8212127808

C 0.05637798490 .45004477341 .7721641227

C - 0.69295115710 .03676595610 .6582648088

C $-0.0261214464-0.5567889658-0.422816349$

C - 2.17871861680 .18752667630 .699940819

C 2.23571386620 .78350887333 .01365214

C - $2.96707630750 .0489006446-0.6143908713$

O -3.9739852835 -0.6252978155-0.7062299025

O -2.431786945 $0.8042531489-1.5841963788$

C -3.0339844328 0.9042003834-2.9360733597

C -2.0826774149 $1.8671536987-3.6490006605$

C -3.0311812293 -0.4719641947-3.6087336924

C -4.441689361 $1.4989243465-2.8366219077$

N - 2.78555878030 .40815465771 .7939830682

Si -4.45791672910.5750996579 2.3311861285

C -5.120335701 -1.1652438042 2.636196437

C - 4.34320743361 .52865617133 .9575446825

C -5.5883362868 1.5414978794 1.1592969681

H 1.8686281738 -1.1995129621 -1.2155917195

H $3.165488636-0.43356170550 .7480009927$

H - 0.4791882160 .89138586472 .6071838146
H - $0.579165463-0.8935340272-1.2927021222$ H 2.9803104040 .0423642143 .3267411528 H 2.77963399581 .70890871312 .782454862 H 1.58408864680 .98970904083 .8683018408 H - $2.41088923462 .0217366627-4.6822886599$ H -2.062025385 2.8370591763 -3.1420508077 H -1.0645618149 $1.4655000482-3.6634444185$ H -3.3910743627 - $0.3733502712-4.6390456232$ H -3.6785972749 -1.1727817247 -3.0791465656 H -2.015577875 -0.8814243646 -3.6450816454 H -4.4212825892 2.4363007286 -2.2707837598 H - $4.8147388871 .7180467776-3.8434144768$ H -5.1328097712 $0.8081439074-2.3513699851$ H -6.1256295297 -1.13034299393.0742961609 H -5.1733055775 -1.7215176878 1.6948179759 H -4.4736220883 -1.7200407112 3.3253592858 H -5.3324116259 1.66483977064 .412350812 H -3.9086405666 2.5241768096 3.8058301337 H -3.7101684368 0.9983701814 .6780940527 H -5.7854594668 0.98846703170 .2370300696 H -6.5499664199 1.73810928441 .6506426042 H -5.15638549392.5139374485 0.8920006764 
Compound (E)-1h

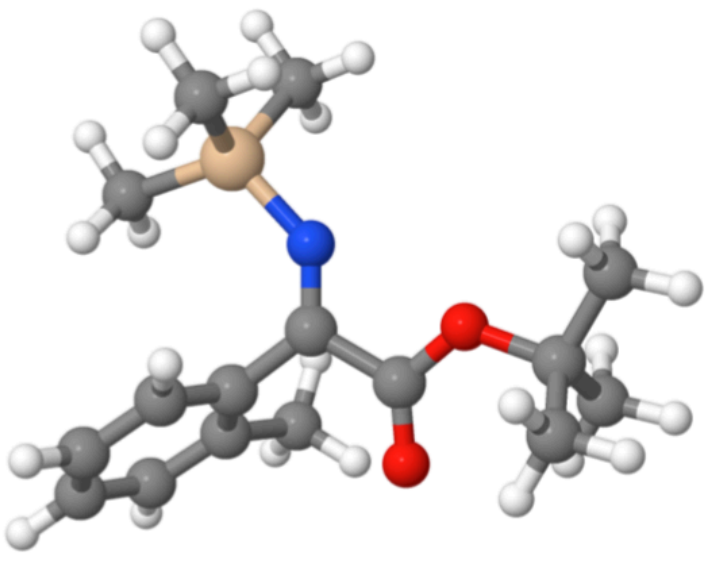

Atom $\underline{\mathbf{X}}$

$\underline{Y}$

$\underline{Z}$

C $0.6873090521-0.2577255408-0.1358292977$

C $0.7838614347-1.62675233020 .1059427645$

C - $0.3688805873-2.36624445320 .3743012798$

C - $1.6350935049-1.77074332040 .4016610394$

C $-1.7229069367-0.38296862520 .1688174159$

C - $0.56448708550 .3568590539-0.0984728716$

C -3.03251295760.36266842590.2289943328

C -3.930475993 $0.165619845-1.0045641064$

O -3.6911942294-0.6871629809-1.8404045857

O -4.95407249161.0206000673-1.0206754241

C -5.9558631122 1.0135283508-2.1054786909

C -6.8987343205 2.1449172223-1.6894527075

C -5.2802997658 1.3300128827-3.4439865935

C -6.6922964634-0.3300117102-2.1267249986

N -3.4172224598 1.1307087505 1.1602372084

Si -2.7942790578 1.62661708342 .7363305195

C -4.2633231929 1.4234601382 3.9042007904

C - 1.31722219890 .66849616873 .4296320584

C - 2.35192613643 .45229209452 .5388881556

C - $2.8636827164-2.60816153220 .6713809767$

H $1.57589621320 .3298602009-0.3499787743$

H $1.7518050654-2.12055848430 .0871531225$

H -0.2882149367 -3.4340274295 0.5649943057
H -0.649559321 $1.4247268728-0.2855289931$ H -7.7073542654 2.2491261921 -2.4207323666 H -7.3388492896 $1.9383689582-0.70886138$ H -6.3579539752 3.0946737273 -1.6295299479 H -6.0459568783 1.4474873586 -4.2192178141 H -4.5983316056 $0.5326622192-3.7434984098$ H -4.7208626186 2.2693523092 -3.3749046695 H -7.1156578301 -0.5473136651 -1.1400455143 H -7.5169149313 -0.2823492244 -2.8469220475 H -6.0250928319 -1.1442239362 -2.4141222481 H -4.0148981138 1.7746164899 4.9134103904 H -5.1280926932 1.99309887133 .5473365347 H -4.56702581010.37295892363.9857141768 H -1.0943043674 1.018595897 4.4462470286 H -0.4158357245 0.79782552172 .8223898312 H - $1.5206896481-0.40687346063 .4890113397$ H -3.1981973318 4.0202000919 2.1376347882 H -2.07805402013.88990574023.5068608508 H -1.50187302473.5910308229 1.8607003657 H - $2.5875924603-3.61472332341 .0001732458$ H -3.4990987468 -2.1649833452 1.4474744584 H -3.4728891306 - $2.7000159178-0.2345565389$ 


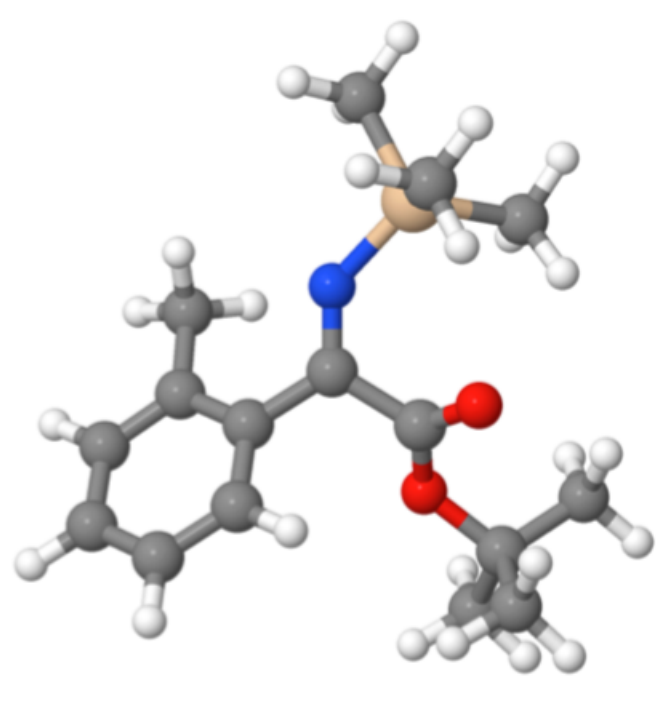

$\underline{\text { Atom }} \underline{\underline{X}} \quad \underline{\mathbf{Y}} \quad \underline{\mathbf{Z}}$

C $0.9936998453-0.27817933-0.3560177379$

C $1.4517292066-1.39385930740 .3431347754$

C $0.5976368943-2.05526628651 .2246751196$

C - $0.7165819013-1.62635396871 .451308185$

C - $1.1800689713-0.49822784190 .7321508892$

C - $0.3167450190 .1499551845-0.1667520847$

C - 2.54393715970 .0787138440 .9374441973

C -3.2433042568 $0.6757109684-0.3016228243$

O -3.8789583709 $1.7114263322-0.2651234954$

O -3.0960216885 -0.1236302366 -1.3659330135

C -3.7054968493 $0.1836773379-2.6815322517$

C -3.2558036908 -1.0028094008 -3.5362663144

C - $5.2310883620 .2207981485-2.5534419522$

C -3.1337219948 1.4982445343-3.2211266673

N -3.10242234270.10808397242.0763866196

Si -4.60615301660 .75333745172 .7489488269$

C - 4.34433016432 .59292229283 .0758341833

C -6.143645550.44457451861.6881726026

C - $4.8288984044-0.16846733084 .3828400609$

C - $1.5733422501-2.39528582922 .4296198216$

H $1.64638933370 .2502857487-1.0453333275$

H 2.467718188 -1.7529879305 0.2010958773

H $0.9573564844-2.93174812081 .7586406902$
H -0.6744667311 $1.0179881225-0.7140594882$ H -3.635399878 -0.8948910464 -4.5578807562 H - 2.1634263189-1.0592916115 -3.573970008 H -3.6343390203 -1.9429605104 -3.1227052995 H -5.677266285 0.3049433847-3.5508106864 H -5.5600606543 $1.0697390159-1.9521055475$ H -5.5988292397 - $0.703142058-2.0944604015$ H -2.0400287322 1.4515935281 -3.2629468991 H -3.5035653807 1.66527087 -4.2389911039 H -3.4307101438 2.3448988737-2.599827208 H -5.2096633561 3.0227644673 .5956582916 H -3.4606367171 2.76282828213.7014807452 H -4.2055260924 3.12964663592 .1323993124 H -7.0462344621 0.68754576812 .2635946267 H -6.2219811931 -0.6089388601 1.3922254888 H -6.1424320147 1.05607654350 .7820708384 H -3.960838663 -0.0239612233 5.0362179433 H -5.7179230918 0.1837283344 .9209828382 H -4.9455843298 -1.2471374421 4.2222461168 H -1.111381594 -3.3615325206 2.6587842265 H -1.7048486519 -1.8418262883 3.3641968806 H - 2.57858841 -2.5778700158 2.0370869099 


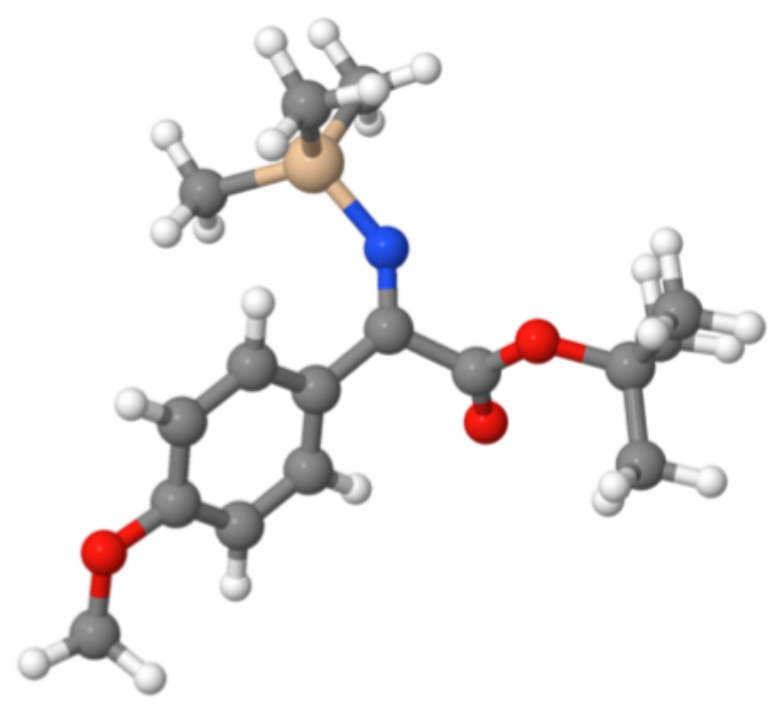

$\begin{array}{llll}\text { Atom } & \underline{\mathbf{x}} & \underline{\mathbf{Y}} & \underline{\mathbf{Z}}\end{array}$

C - 1.75608260810 .22078731840 .6946215633

C -1.3127363528 -1.0334258359 0.2444970916

C - $2.2177988852-1.9038196417-0.3759618765$

C -3.5485001761 -1.519469303 -0.5427692494

C -4.011702038 -0.2810518152-0.0735089995

C -3.08455634630.58293030420.5405751344

C -5.4281610754 $0.1600823642-0.2342543558$

C - $6.1224491907-0.2545019721-1.5364725343$

N -6.13569203880.83097087220.5792247979

O -6.56575234180.8134233924 -2.2043438689

O -6.2606223638-1.4194159562 -1.8637076889

C -7.3677907224 $0.6849210393-3.4410041647$

C -7.6467122525 2.1448576591 -3.8048964133

C -6.5400861447 -0.0017974635 -4.5322906805

C -8.6702901296-0.0609153547-3.1358718925

O $0.0065692852-1.30017361130 .447736897$

C $0.521386872-2.5452919833-0.0015638757$

Si -6.140507357 1.3922329607 2.2388793489

C -7.93208505761.2243601669 2.8093082139

C -5.04709357730.4184349282 3.4420981817

C -5.65654586563.22117051312.2193841336

H -1.0359346965 0.89254172611 .1511894507

H -1.9003690815 - 2.8767163277 -0.7333908071

H -4.2430298108 -2.1948227397 -1.028510256
H -3.4098555455 1.56480324250 .8695947429 H -8.2455387699 2.1963096378 -4.7204552097 H -8.1952591889 2.6443360759 -3.0001720665 H -6.7104013545 2.6872576597-3.9712075159 H -7.0914539206 0.0243764633 -5.4790854097 H -6.3317214235 -1.0418428083 -4.2766333712 H -5.5906207163 $0.5248899779-4.6781650491$ H -9.1991315891 $0.423195983-2.3079910485$ H -9.3201291523 -0.0363902707 -4.0180429146 H -8.4786435741 -1.1021102932 -2.8713720047 H $1.58130012-2.54078126550 .2583968125$ H $0.0284053562-3.38888312920 .4985701855$ H 0.4139941842 -2.6562424575 -1.0883155006 H -8.0585215149 1.58099145713 .8392774056 H -8.60244295961.80269705462.1638118504 H -8.26243682230.179301604 2.7770145217 H -5.2295646578 0.75867229834 .4699419507 H -3.977949876 0.52790698013.236034423 H -5.2813096704 -0.6523654409 3.4066066661 H -6.256161145 3.7754782391 .4887824719 H -5.8299521293 3.67105046813 .2049716869 H -4.6002856952 3.37415028341 .9691802237 


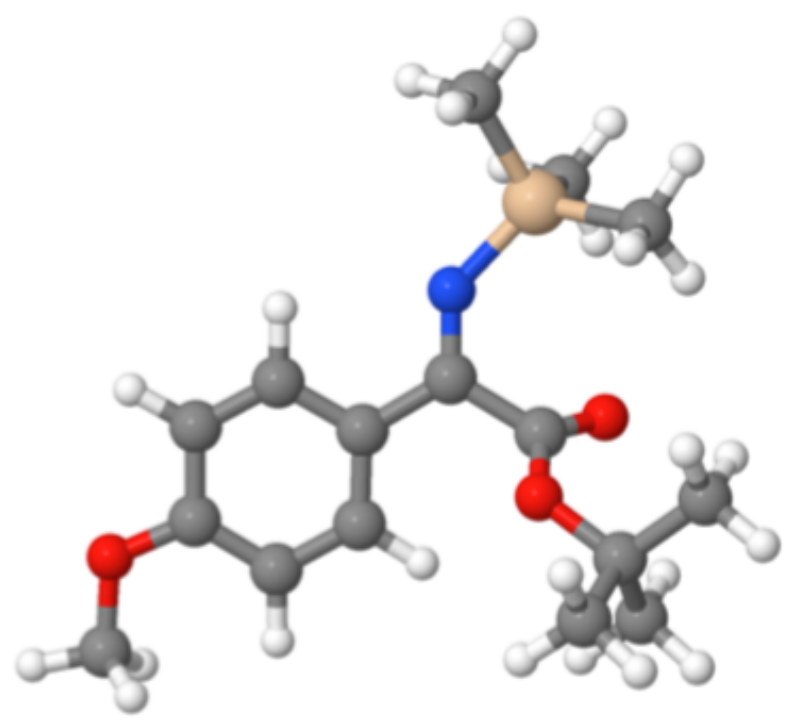

$\begin{array}{llll}\text { Atom } & \underline{\mathbf{X}} & \underline{\mathbf{Y}} & \underline{\mathbf{Z}}\end{array}$

C - 2.65344620990 .03231997342 .1109398572

C -1.944292153 -0.9005553552 1.3333775535

C - $2.5743860972-1.51170331080 .2431907124$

C -3.8954438652 -1.1823668922 -0.0630599765

C - $4.6158310091-0.25629237560 .702054529$

C -3.96559451160.3394919795 1.8015545591

C - 6.04264173570 .07388686310 .4438196281

C - $6.6828462779-0.4253187216-0.8626274856$

N -6.73277872170.728510605 1.2885524532

O -5.9717279722 -0.03372699-1.931569971

O -7.7266581434 -1.0465344876 -0.886585101

C - $6.3975450142-0.3291432739-3.3209476287$

C -5.290045209 0.3247954449-4.1496860042

C -6.428949644 -1.8444836998 -3.5427769232

C -7.752105611 $0.3255512539-3.6059897734$

O -0.6614373584 -1.1379476703 1.7209427154

C $0.1058808966-2.07660985960 .9818130487$

Si -8.40286298291.25606352381.4614874567

C -8.31531725072.7863057912 2.5653915845

C -9.2922441742 $1.7370015296-0.1403862852$

C - $9.3226831633-0.14073860622 .3371106003$

H -2.147015295 0.4954814192 .9521424166

H - 2.053010646 -2.2386817364 -0.3687086799

H -4.3611608125 -1.6662226684 -0.9144549226
H -4.5249834415 1.04770841112 .4035918295 H -5.479420246 0.1703259163 -5.2172185307 H -5.2469063213 1.4012940744 -3.9563803311 H -4.3151195486 -0.1076090582 -3.903194636 H -6.6538997602 -2.0533911295-4.5947895605 H -7.1907944419 - 2.3197955688 -2.9226393346 H -5.4537367953 - 2.2884933922 -3.3135128718 H -7.7225475875 $1.3914835892-3.3567546306$ H -7.9814444605 $0.2331244433-4.6736527031$ H -8.5520148616 -0.1484131536 -3.0354224461 H 1.0845533652 -2.1075345585 1.4637786639 H -0.3452346787 -3.0769508235 1.0110256569 H $0.2256458047-1.7643418501-0.0637577248$ H -9.3167913203 3.17471421382 .7893989125 H -7.8213760726 2.55658458283.5162852036 H -7.7479842876 3.59227918292 .0842348798 H -10.24395945332.22915776930.0982357618 H -9.5079969013 $0.8640562558-0.7624997077$ H -8.7019256237 2.4444958921 -0.7358894292 H -8.8304090001 -0.4115662994 3.2778396836 H -10.3543114994 0.15207471072 .5689163291 H -9.354458907 -1.0315879437 1.7006886219 
Compound $(E)-\mathbf{1} \mathbf{j}$

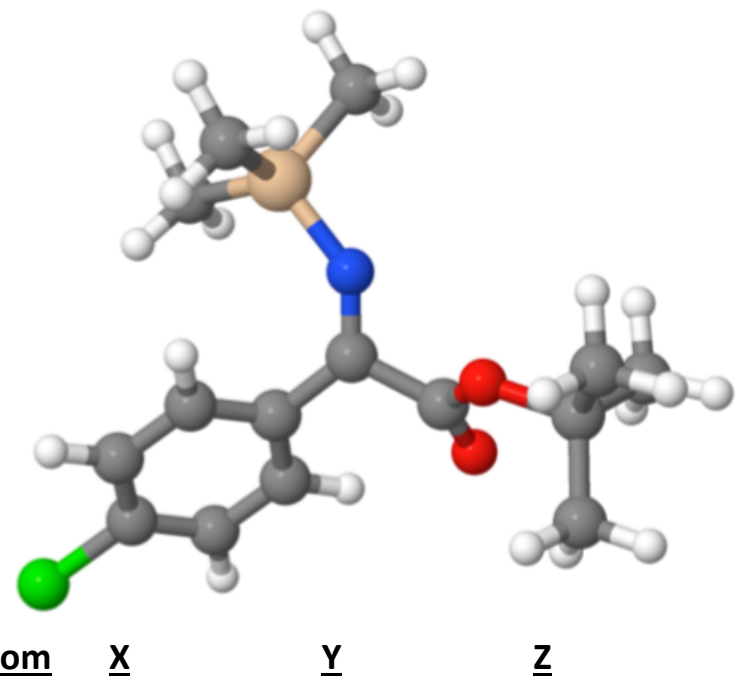

$\underline{\text { Atom }} \underline{\mathbf{X}} \quad \underline{\mathbf{Y}} \quad \underline{\mathbf{Z}}$

C - 1.98150018350 .53143062930 .1982489365

C - $-1.421363043-0.6370345899-0.3173354681$

C - $2.2248647247-1.7014296274-0.7240459732$

C -3.6102146023 -1.5945836282-0.6147529979

C -4.1993414996-0.4392821931-0.0747998248

C -3.36606008260.61877408170.3206230691

C -5.6830509525 -0.2825517684 0.0720307147

C -6.5302236735 -0.741799629-1.1218029625

N -6.31124506120.17273100821.0749742565

O -7.4128752702 $0.1928921771-1.4733079133$

O -6.3989578229-1.8419025854 -1.6274273242

C -8.4206895873 -0.0405397869-2.5332342534

C -9.1979595585 1.2772874057-2.5421015919

C -7.7189888033 -0.2723373235-3.8751117985

C -9.3281929063 - $1.2085025257-2.1357393083$

Si -6.0277135085 0.61852115222 .75245692

C - $-7.530450184-0.04065547053 .683179256$

C - $4.4673898768-0.09477607943 .5544538027$

C -6.01235159432.5080278192.8110076994

Cl $0.3250729914-0.7634998592-0.4669131624$

H - 1.34427274171 .35855287990 .4924975093
H - $1.7719216814-2.6017759319-1.1253770851$

H -4.242373705 -2.4095981939-0.9452828728

H -3.8087130727 1.53314781090 .70412689

H -9.9908358731 1.2401319379 -3.2966192319

H -9.6544934441 $1.4620885647-1.5647072682$

H -8.5345425051 2.1159379412 - 2.7765385731

H -8.4672483532 -0.318151293-4.6744178277

H -7.1535898141 -1.2056383356-3.8716315535

H -7.0368317196 $0.5556319847-4.09681278$

H -9.7523416124 -1.0380809241 -1.1405182933

H -10.1551163855 -1.2855706322 -2.8505905552

H -8.7820216425 -2.1531954522 -2.1305935328

H -7.4868328779 0.2235408109 4.7471131028

H -8.4568412034 0.37038444653 .267273371

H -7.5927519651 -1.1332354708 3.6154434381

H -4.47740501530.114665965 4.6320845488

H -3.54329535170.3203528545 3.140803208

H -4.4219027407 -1.18380204 3.4344048011

H -6.89958598872.92152624612.3190458651

H -6.01149947732.85743558288 3.850931175

H -5.1289988857 2.9331047962 2.320382588 


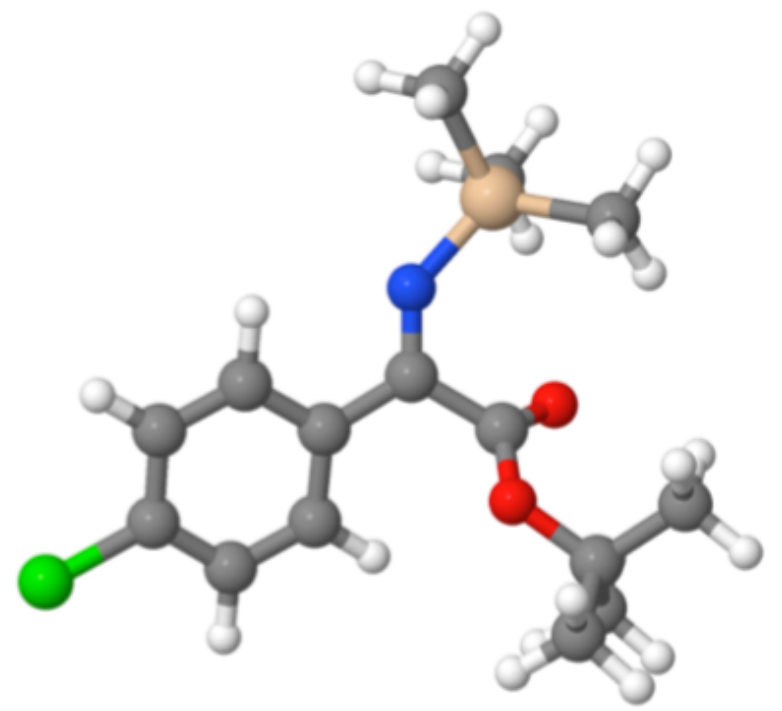

$\begin{array}{llll}\text { Atom } & \underline{\mathbf{X}} & \underline{\mathbf{Y}}\end{array}$

C - $2.6356769048-0.13685051692 .1915694161$

C -1.974525733 -1.1102755979 1.4396437076

C - $2.6157953396-1.76846370610 .3923015134$

C -3.9348021244-1.4364280944 0.0879499946

C - $4.6243505092-0.46275862110 .8261022883$

C -3.9554749947 0.17260320771 .8850088557

C - $6.0574731351-0.12044513040 .5753545203$

C - $6.6926525696-0.5419848261-0.7615047119$

N -6.74079874810.49262595961.4522703584

O -5.9027939148 -0.2241734981-1.7964213159

O -7.7960499163 -1.0456387494-0.8298776069

C - $6.3049260774-0.4609669343-3.2061464138$

C - $5.10326079380 .0773252385-3.9848320627$

C - $6.4898510409-1.9623844319-3.4451390427$

C -7.5695317568 $0.3395030191-3.5297203786$

Si -8.41482852661.02848322411.6422772059

C -8.3326027744 2.37671222192.961380516

C -9.194572188 1.7702247720 .0853056458

C -9.4040464671 -0.4491786553 2.2723095282

Cl -0.3070167059-1.5122554453 1.8211479289

H -2.1208489877 0.36557964143 .0036214564
H -2.0907196706 -2.5285763359-0.1761765317 H -4.4240688198 -1.9505921509-0.7314871846 H -4.4963104871 0.91372813892 .463784011 H -5.2664137582 -0.0509094733 -5.0600254038 H -4.9550783847 $1.1423516921-3.7804587046$ H -4.1892192678 -0.4565540941 -3.7062242461 H -6.694054725 -2.1383861368 -4.5072128578 H - $7.322314368-2.3579752736-2.8607947531$ H -5.5775257936 -2.5103321605 -3.184130403 H -7.4337541996 $1.3931152791-3.2638301087$ H -7.7664014207 $0.2838814359-4.6062217161$ H -8.4374975866 -0.0513107785 -2.996640223 H -9.3308794792 2.7654725049 3.1982780004 H -7.8917307161.99204738213.8880876592 H -7.7186218318 3.22257054272 .62907 H -10.1534354285 2.23948555678 0.3405179797 H -9.38163272 $1.0114213249-0.6792918576$ H -8.5587714236 2.5501089608 -0.3518177829 H -8.9578549296 -0.8664756997 3.1820928291 H -10.4344564741 -0.15599496132.5088760707 H -9.4353323072 -1.2373648418 1.5135258197 


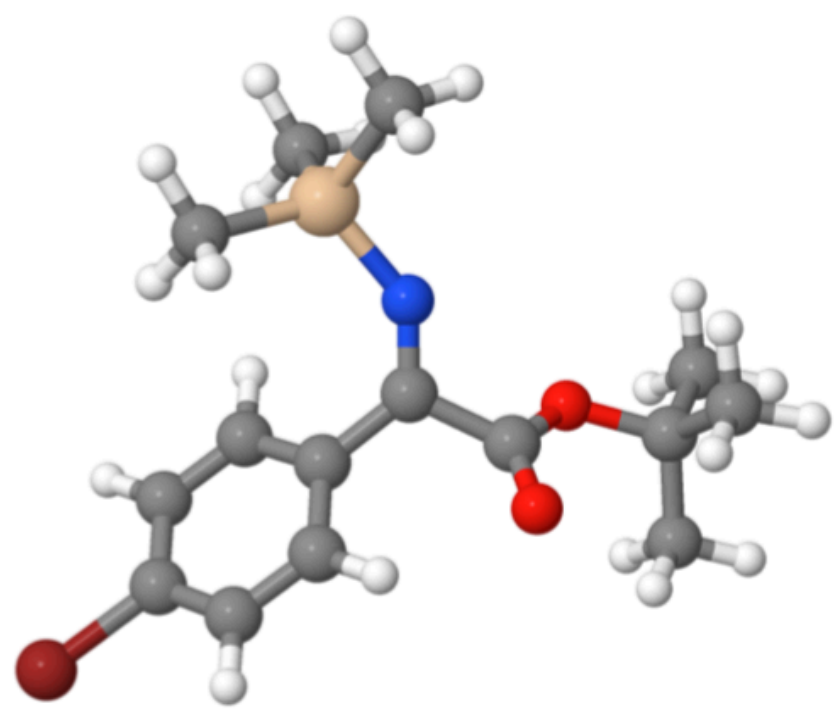

$\begin{array}{llll}\text { Atom } & \underline{\mathbf{X}} & \underline{\mathbf{Z}}\end{array}$

C - $2.1803107309-1.534514825-0.8223216792$

C - $2.0175922222-2.31559183750 .3202336234$

C - $2.9875847402-2.33900116821 .3210623366$

C - $4.1270967736-1.55165667781 .1747489586$

C - $4.3150438076-0.74989371980 .0378996405$

C -3.3334675466 - $0.7647080151-0.9670897753$

C - $5.56748176350 .0661263515-0.0709319271$

C - $6.25151581360 .0684388479-1.4433854252$

N -6.11338602420.76372476590.8363115259

O -7.5401789854 -0.256181492-1.3398767864

O -5.6583781955 0.3690628219-2.4636075988

C - $8.4530294788-0.2218569551-2.5063391678$

C -9.7893845165 -0.6373969078 -1.8882882956

C -8.5253440585 $1.2038984369-3.060692772$

C -7.9944779246-1.2383186267-3.5565596876

Si -5.7781706951 1.38574475632 .4464611819

C -6.76531131080 .32087194123 .6572936685$

C -3.9528937213 1.45786932592 .9455857028

C -6.46127992 3.144152252 .4348660704

Br -0.4450635607 -3.3833657759 0.5149202437

H - $1.4167023089-1.5302304048-1.5924841181$

H - $2.8559951889-2.96665337242 .195635582$
H -4.8950597696 -1.5797153526 1.9416727807 H -3.475704656 -0.1660547904-1.8586805825 H - $10.5704137626-0.6500900656-2.6559226644$ H -9.7180697531 -1.6376337783 -1.4491073669 H -10.0846837289 $0.0638832223-1.101605633$ H -9.2965461288 $1.2545943251-3.8376448238$ H -7.5721543363 $1.5101813796-3.4948237484$ H -8.79557777007 $1.9071267188-2.265796543$ H -7.8996378854 -2.2334818085 -3.1085703824 H -8.7407862058 -1.2965565061 -4.3568969743 H -7.0355950874 -0.9537418162 -3.9925923616 H - 6.74920863990 .76951082674 .6583794876 H -7.8118933630.2393034583 3.3438524403 H -6.3623316886 -0.6947991115 3.7461738154 H -3.8516244729 1.99287126783 .8989150456 H -3.359228142.0024995105 2.2016293776 H -3.50150191630.4684523923.0668069136 H -7.5282085085 3.14651696812 .1861830992 H -6.3375733402 3.62560661923 .412931558 H -5.9467496282 3.76549582161 .6922822611 


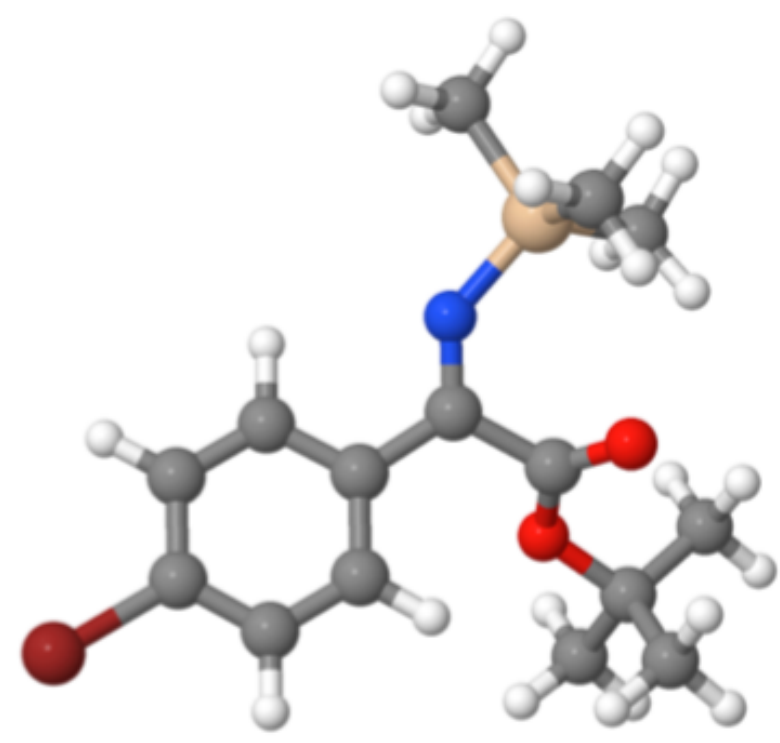

Atom $\underline{\mathbf{x}}$

$\underline{Y}$

$\underline{z}$

C - $2.8741789027-0.40379744522 .2669693248$

C -2.0491291959-0.7350549559 1.191005256

C - $2.5530654555-0.8136166296-0.1048466326$

C - $3.9080243078-0.5689415702-0.3227382413$

C $-4.7616494507-0.2341053520 .7392326909$

C -4.2201789957-0.1476212114 2.0322245523

C -6.20589958330.09783029010.5435775225

C - $6.8856200638-0.3155984781-0.7739404278$

N -6.85503439370.72029165231.4397001742

O -6.6002454165 -1.5860860594-1.0905680581

O -7.6243101482 $0.4277310562-1.3885378903$

C -7.1799915515 -2.2585613591-2.2809235415

C -6.5786623606-3.6622389923 - 2.1898257754

C - $8.7057242177-2.3084393151-2.1612372836$

C - $6.7190956993-1.5423195604-3.5537969367$

Si -8.48520969161.3787460141 1.6281588913

C -8.7079328259 1.56560771353 .4936213065

C - 8.50165870013 .06936350670 .7911399305

C -9.87179830420 .26882613990 .9744875713$

$\mathrm{Br}-0.1971711005$-1.0876304976 1.5003325354

H -2.4653633537 -0.3467199782 3.2699996919
H - $1.896855682-1.0631780165-0.9313667128$ H - $4.2924070528-0.6374776588-1.3341472567$ H -4.8794280633 0.12728172372.8487183542 H -6.9193564535 -4.2705425655 -3.0342143041 H -5.4851975734 -3.6183505903-2.2122756505 H -6.8839283803 -4.1547351309-1.2612405137 H -9.109533967 - 2.942454516 -2.9584670286 H -9.1467132942 -1.3144922173 - 2.2496925281 H -8.9998057623 - 2.7435978631-1.2002881719 H -5.624994176 -1.5048067846 -3.6014462556 H -7.0737837593 -2.0959299303-4.4303399284 H -7.1127910555 -0.5256340348 -3.6019494656 H -9.6797566852 2.0132865008 3.736442341 H -8.6550119284 0.59475385334 .0010780737 H -7.9262939952 2.20469071013.9198945106 H -9.4588195881 3.57851810290 .9592899316 H -8.3539019428 2.9599572718-0.2877857771 H -7.7066517506 3.71397090511 .1827476657 H -9.7872622696 -0.753513603 1.3633758376 H -10.84345246140.660474629 1.3019313869 H -9.8755994405 $0.2212642461-0.1177331687$ 


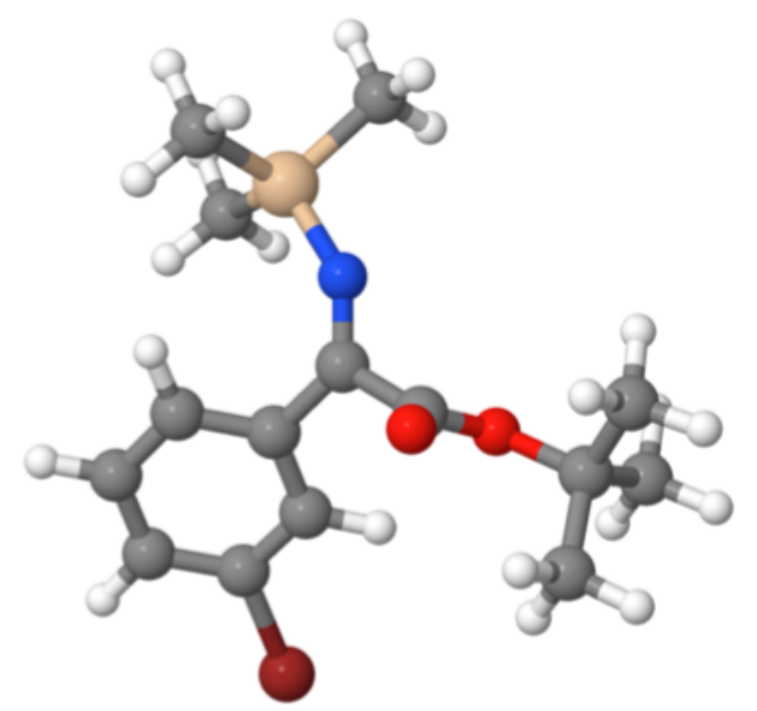

$\underline{\underline{A}} \underline{\underline{\mathbf{X}}} \quad \underline{\mathbf{Y}} \quad \underline{\mathbf{Z}}$

C -3.49565862190.20237937540.5045753512

C -3.1308338015-1.0235108631-0.0555502519

C - $4.1342315985-1.8875098062-0.4903141957$

C $-5.4801375051-1.5522052388-0.3818357543$

C - $5.8420225627-0.32975609280 .204400198$

C - 4.83903766340 .54773620420 .6394340079

C -7.2894966068 0.03813972360.3293476588

C -8.1390232159-0.2148855558-0.9219851699

O -8.2772280567 $0.6171478681-1.7914264508$

O -8.6888513841-1.4388683933-0.8787852285

C -9.6304017283 -1.9106036872 -1.9264544858

C -9.9859717912 -3.317073018 -1.441665146

C -10.8664719529-1.0067813625-1.9435217003

C -8.9213711183 -1.9590429636-3.2829489782

N -7.87749395530.59377180651.3016902043

Si -7.60443601341.106084975 2.9590928121

C -9.220365772 0.73019791293 .8565920364

C -6.19973902750.22578176393.8767303758

C -7.30995165892.97224740492.9084158516

$\mathrm{Br}-3.6523267606-3.5706763299-1.2612371227$

H - 2.72198397850.89209488770.8301573832

H - 2.087594381 -1.3006995367 -0.160068923
H -6.2439023403 -2.2380058298 - 0.7297189384

H -5.1162773851 1.5111570681 .0547735212

H -10.6929805326 -3.7843896428 - 2.1351813227

H -9.091235768 -3.9455286701 -1.384279389

H -10.4457989495 -3.2803242037 -0.4490202178

H -11.6173474967 -1.4296590927 -2.6205513063

H -10.6180845583 $0.0002170369-2.2829250715$

H - $11.3060964723-0.9444637475-0.9424523974$

H -8.0211456132 -2.580854506 -3.2256027623

H -9.5917490627 - 2.4044888722 -4.0268321129

H -8.6411886509 -0.9595791322 -3.6191577234

H -9.1811030065 1.05930167844 .9024486102

H -10.0626816194 1.2357932027 3.3718358311

H -9.433899318 - 0.34527721923 .8549402765

H -6.2032374977 0.53013680454 .9316026919

H -5.209931694 0.44896239913 .4668113622

H -6.3295077765 -0.862864028 3.8515416969

H -8.1119632169 3.47953851682 .3610118112

H -7.2845789644 3.38350734723 .9251753259

H -6.3612849226 3.23106581612 .4238156422 


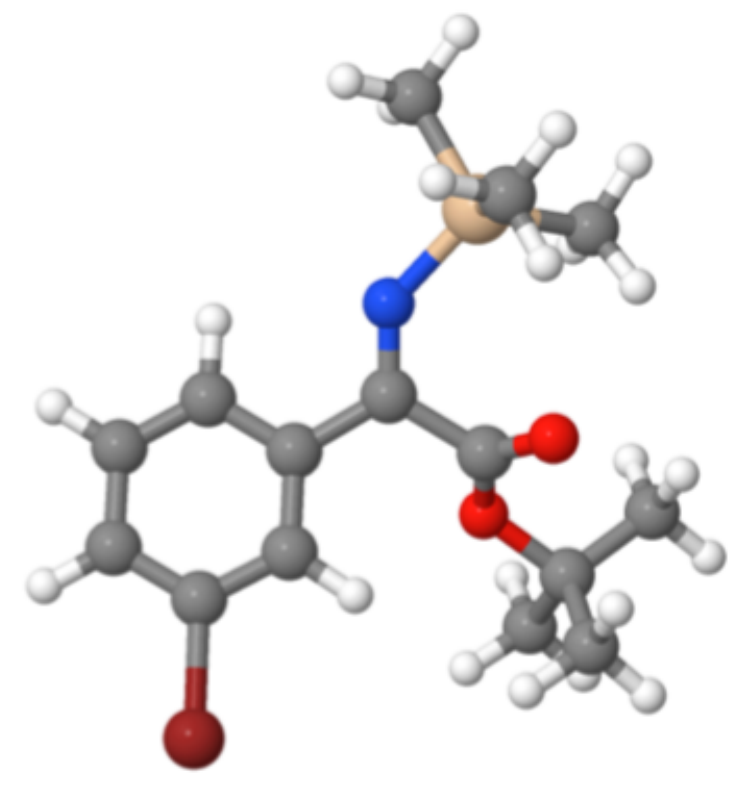

$\begin{array}{llll}\text { Atom } & \underline{\mathbf{X}} & \underline{\mathbf{Y}}\end{array}$

C -3.9534833346 -1.98330385392.533434988

C -3.0950837371 -2.3113070433 1.4802194237

C -3.3979332741-1.844198635 0.2043343267

C - $4.5307810097-1.0741227629-0.0416416198$

C -5.3904386231-0.7475229663 1.0176356343

C -5.0844884831-1.2057221046 2.3089203395

C -6.5940042574 0.12314629340 .8274118154

C -7.1029994198 0.3722350594-0.6029401286

O -7.2175682312 -0.7764558054-1.2819993688

O -7.3991554924 $1.479277537-1.0058954718$

C -7.7313340996 -0.831918372-2.6749337809

C - $7.6763901001-2.3289016934-2.9847247929$

N -7.16732091140.65802920191.82492681

Si -8.5131147545 1.77248787522 .0955518711

C - 7.80882824933 .51688431451 .9556437247

C -9.9991728322 1.53728578490 .9475493374

C - 9.07009494181 .42000551353 .8646701256

$\mathrm{Br}-2.2331578568-2.2749881502-1.2539629334$

C -9.1718036991 -0.3151854907-2.7194731873

C -6.8000378248 -0.0422436061 -3.5994034977

H -3.7298724098 -2.3410578834 3.5346993225

H -2.2102949611 -2.91605891161.6463882794
H -4.7333350475 - $0.7355167607-1.0493944473$ H -5.7504429413 -0.9343701238 3.1205589556 H -8.026148135 -2.5120128917-4.0061543874 H -6.6531607156 -2.7067594594-2.8948083825 H -8.3132597475 -2.8904860808 -2.29392867 H -8.5662677397 4.2650043842 .2205003543 H -6.9525644906 3.65536201972 .6251993699 H -7.4768349293 3.71174817420 .9307191294 H -10.8510836733 2.1201796341.3206624738 H - 10.317175710 .48803033270 .9087097402 H -9.7814700512 $1.8668498625-0.0718686219$ H -8.2424327061 1.55086518764 .5709327767 H -9.8822335366 2.09273079394.1673683025 H -9.43634013310.391614061 3.9705473357 H -9.5915501521 -0.5022519651-3.7142125039 H -9.2190272431 $0.7560331197-2.517701353$ H -9.7909382873 - $0.8426947586-1.9860953345$ H -5.7743034381 - $0.4215411027-3.5319744414$ H -7.1334719414 -0.1610611159-4.6364262265 H -6.8039378781 1.0210353885 -3.3532182869 


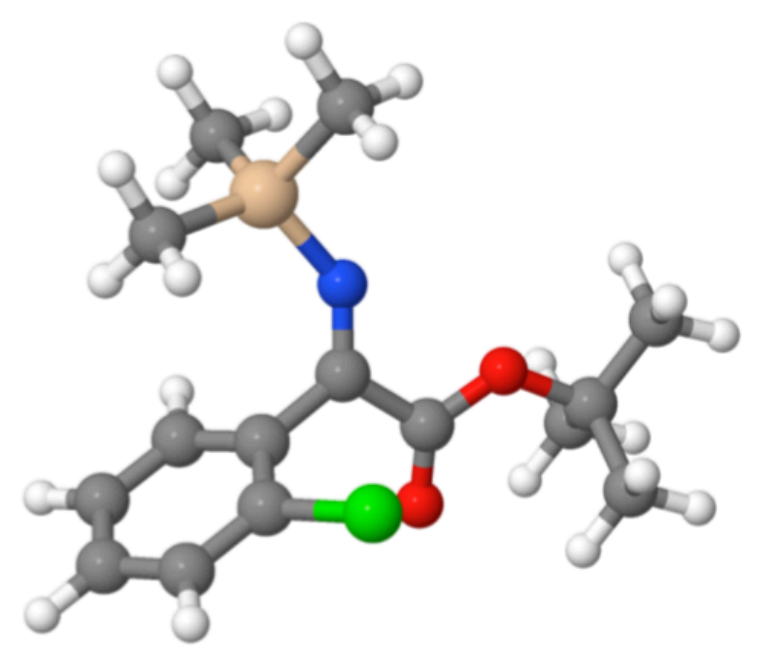

Atom $\underline{\underline{X}} \quad \underline{\mathbf{Y}} \quad \underline{\mathbf{Z}}$

C - $2.7216970824-2.46103840380 .7513531306$

C - $1.6960450199-1.7885040480 .0858002172$

C -1.9692009339-0.6123133747-0.6120917281

C -3.2736105662 -0.122908202 -0.6418435336

C - $4.3193210235-0.77411892760 .0214717964$

C -4.018778203 -1.9519193809 0.7187596845

C -5.7346402851-0.2514867365 0.0169180174

C -6.4479937101-0.4391542474-1.3306021649

N -6.3622617458 0.22006566291 .0077822829

O -7.55474001990.2982499945 -1.4147015993

O -6.0112383286-1.1986825012-2.1742956054

C - $8.42090834050 .2624591781-2.6109622715$

C $-9.53651896081 .2414513964-2.2387102338$

C -7.6401985612 $0.7601075893-3.8317691496$

C -8.9781430779-1.1507279187-2.8100755845

Si -5.99566803750.62782932482.6863226658

C -6.9101877195 -0.6561816893 3.7271818024

C - -4.16623304560 .68357524093 .1667111468$

C -6.7491504362.3395562782 2.9270517871

Cl -3.58981109 1.3732738585 -1.5178972384

H -2.5140926098 -3.3802230764 1.2914339832
H - $0.6811133923-2.1751158650 .1065178586$

H - $1.1820499963-0.0748267369-1.1301996727$

H -4.823317802 -2.4760107523 1.2276252565

H -10.2625813781 1.3124267858 -3.055599314

H - $10.05770290010 .9067579445-1.3362310709$

H -9.1268354614 2.2385372604-2.0487234374

H -8.3194839628 $0.8483635679-4.6872814056$

H -6.8336895513 0.0734991414-4.094089313

H -7.2128049895 $1.7486947592-3.63274601$

H -9.4785796652 -1.4944545884 -1.8982648184

H -9.7168641236 -1.1400766235 -3.6195178726

H -8.1868904915 -1.8562832122 -3.068177944

H -6.8483894673 -0.4031888357 4.7928478907

H -7.9696610139 -0.7026918426 3.4527826268

H -6.4861663984 -1.6593112249 3.6009814116

H -4.0658958492 1.0616572714 .1926270303

H -3.5981293796 1.35518121172 .5126190148

H -3.6895603129 -0.3008599232 3.124048553

H -7.81693082 2.33311497162.6833897019

H -6.6358717764 2.6788874452 3.9641627678

H -6.26513447113.0807902293 2.2804383413 


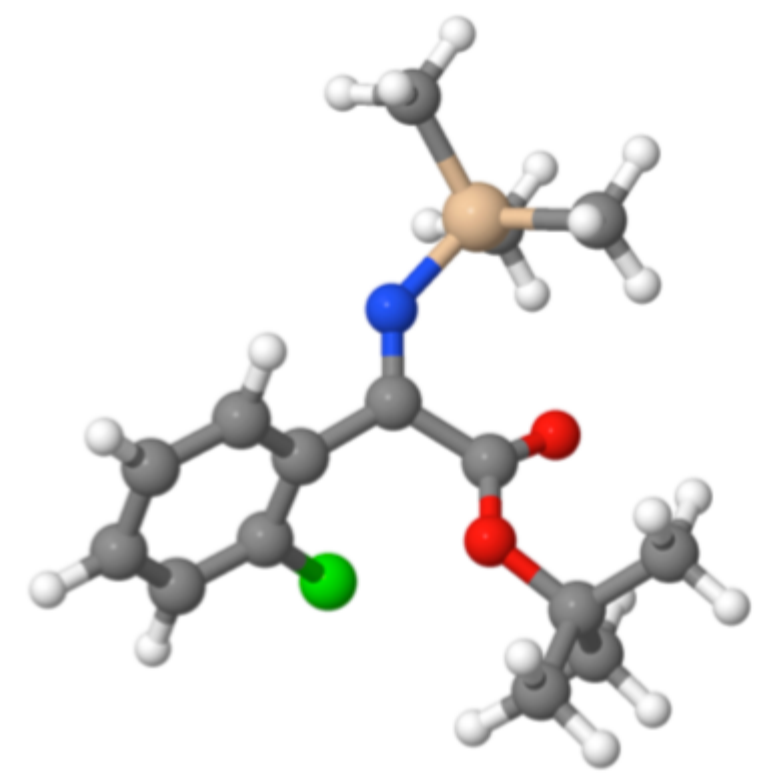

$\begin{array}{llll}\underline{\text { Atom }} & \underline{\mathbf{X}} & \underline{\mathbf{Y}} & \underline{\mathbf{Z}}\end{array}$

C -2.9091146153 1.2074432347 1.2878337383

C - 2.18998858510 .19295028640 .6535749655

C - $2.8663135918-0.8490749520 .0209708275$

C -4.2602703934-0.8557482011 0.0104706872

C -5.00778619930 .15907393210 .6229507689$

C -4.3005437061 1.17846882161.2783693469

C -6.50889250540.19112706260.6677796182

C -7.278925 0.0702180005-0.6592960097

N -7.0986463529 0.3915179501 1.7694174292

O -6.55984863380.5703970513-1.6690678458

O -8.4129493718 -0.3603632942 -0.7223771819

C -7.08464975920.6475820371-3.0545356453

C -5.9081488276 1.2586099645 -3.817893753

C - $7.4051434497-0.7570600364-3.5725457585$

C -8.3024359252 $1.5757580857-3.0886275371$

Si -8.78434756110.51951590572.3162859243

C -8.6488948561 1.21898904774.0650352453

C - 9.82768466431 .71307117611 .2838534353

C -9.5196707181-1.2159660765 2.3731499686

Cl -5.0683903323 - 2.233879419-0.7388057482

H -2.3875929356 2.0155505837 1.7925502887
H -1.10366283120.20181677350.6575978973 H -2.3237628237 -1.660348273 -0.4527015234 H -4.87356319931.95058374531.7818616571 H -6.1692117228 1.3766127524 -4.8748358943 H -5.651670784 2.2421894907 -3.4115072239 H -5.0258055430.615063647 -3.7471581212 H -7.6839528015 -0.69508588 -4.6306691895 H -8.2322258597 -1.2055560058 -3.0198935438 H -6.5281873849 -1.4063940462 -3.4870750826 H -8.0547753665 2.5486936062 -2.6504884418 H -8.605378807 $1.7394575635-4.1288784865$ H -9.1456232492 1.1462328103 -2.5449118491 H -9.6359925514 1.31543276844 .5344991283 H -8.0353426101 0.5703350274 .7006885255 H -8.1847179867 2.21268879144 .0626757722 H -10.7890132209 1.89028326471 .7830402078 H -10.0281102071 1.31826135470.2846613195 H -9.3338055348 2.68683561391.1777220628 H -8.8961447465 -1.8897590006 2.9719321092 H -10.5194888276 -1.19853055362.8246694371 H -9.600621958 -1.6286566103 1.3635184747 


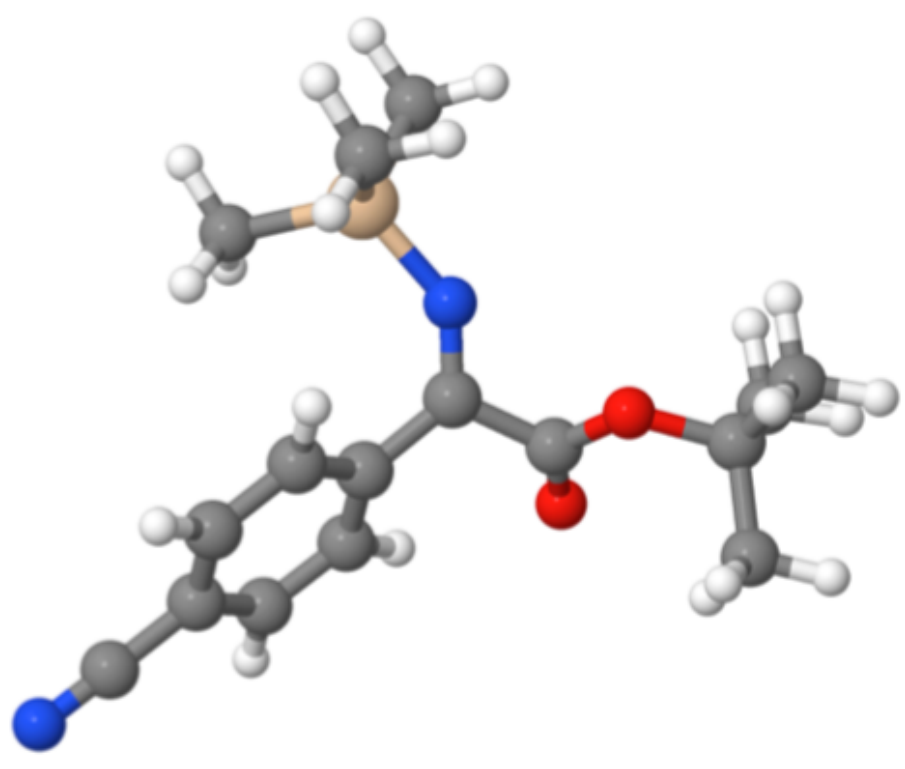

$\begin{array}{llll}\text { Atom } & \underline{\mathbf{X}} & \underline{\mathbf{Y}}\end{array}$

C -3.8451396399 1.26901200470.2429123597

C - $2.95398188480 .3127165299-0.271605919$

C -3.4189781504-0.9749586192-0.5857974075

C $-4.7568887321-1.3023934226-0.3909104328$

C -5.6490649739-0.3586726769 0.1453972312

C -5.17617453310.92774752750.4515437249

C -7.0992896331-0.66545811730.3875895776

C -7.8361922586-1.3657541199 -0.7620420204

O -7.3749463304 -2.342191537-1.3248561477

O -9.0104018964-0.7874230898-1.0050499087

C -9.9628464945 -1.3341638847-2.0012032209

C -11.1399334549 -0.3629160186 -1.8945441183

C -9.3362491992 -1.2871513862 -3.3980304697

C -10.3809913779 -2.7493635071-1.5920723971

N -7.7616107475 -0.42363639361.4398986319

Si -7.51289876460.10002460673.1030649382

C -8.6082598696-1.0427330776 4.1279475209

C $-5.7415926164-0.01148413833 .7625251068$

C -8.1522879124 1.87562462043 .1931812277

C - $1.57707331110 .653582395-0.4821060888$

N -0.460083362 $0.9311319201-0.6516505919$

H -3.4894846568 2.26879156030.4702175995
H - 2.7288408162 - $1.711013217-0.9854525079$ H -5.1197770932 - 2.2880894435 -0.6537586368 H -5.8670750487 1.67207531760 .835568699 H -11.9331988669 -0.6572909641-2.5897346295 H -11.548453764 -0.3621451609-0.879185993 H -10.8241662325 $0.6561476861-2.1397414918$ H - $10.0865968496-1.5748694698-4.1428773817$ H -8.4876938451 -1.9687128627-3.4762386534 H -8.9992191773 -0.2713571199-3.6315060471 H -10.7590864693 -2.7519340989-0.5642569818 H -11.1847055468 -3.094939261 -2.2517954241 H -9.5460781793 -3.4483453532 -1.6643918088 H -8.5740728745 -0.775349784 5.19134594 H -9.6502978515 -0.9858725886 3.7950517002 H -8.2875588605 -2.087412746 4.0389296487 H -5.7400251911 0.17345647534 .8445766856 H -5.0646870815 0.7129470759 3.2991946016 H -5.3170696638 -1.00971306 3.6022426354 H -9.1664093129 1.94860592412 .7856020345 H -8.18336298632.2162553816 4.2354803711 H -7.51647648932.57479809312.6375270438 


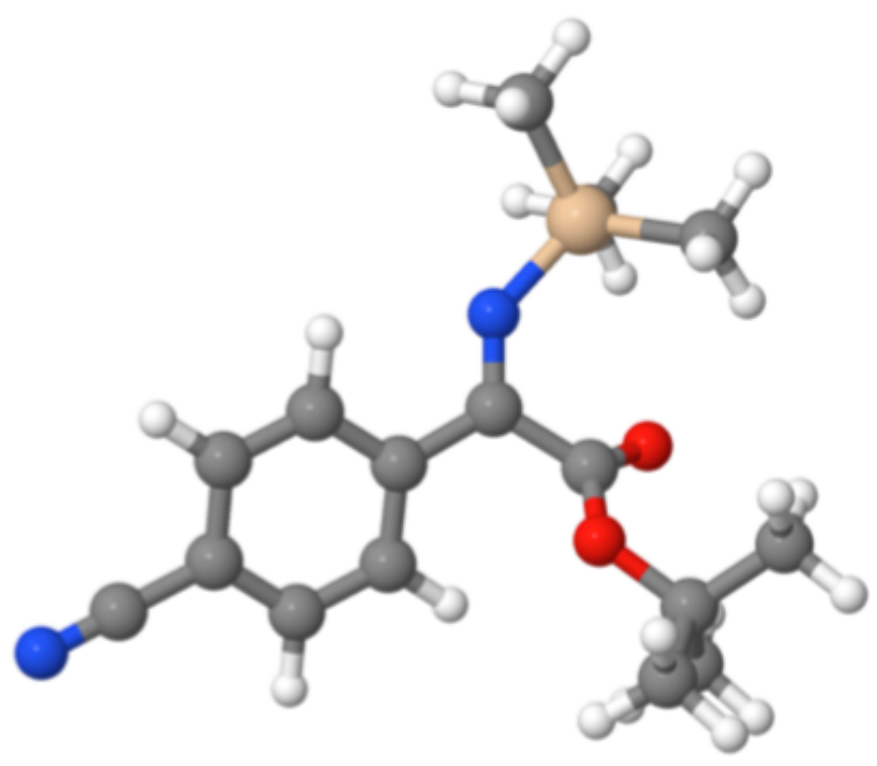

$\begin{array}{llll}\text { Atom } & \underline{\mathbf{X}} & \underline{\mathbf{Y}}\end{array}$

C -3.1012057416 - 1.53832685550 .2036726044

C - $2.3604399108-0.86676282641 .1887553001$

C -3.00076085070.05969412192.0316281442

C - 4.35892369910 .30222692561 .8854266385

C -5.1069878546-0.3526941860.8930504759

C -4.4592404766 - 1.27559748570 .0571950307

C -6.5787952897-0.0856605954 0.8120377405

C -7.3280983584-0.4776395645 -0.4733876576

O -8.4103959982 -1.0285810386 -0.4543865476

O -6.6592849676 - $0.0791358147-1.5629648461$

C - $7.1918996413-0.267846643-2.938050029$

C -6.0974707575 $0.3600608056-3.8025557484$

C - $7.3391071147-1.7633376231-3.2324767261$

C -8.5137624424 $0.4891714782-3.0916736311$

N -7.18975316360.4403274004 1.7912522287

Si -8.86306644960.86964641912.1876356307

C -8.7032603104 2.1479680372 3.5666471833

C -9.83580659381.6463656770.763094661

C -9.6963717173 -0.6961233193 2.8279951244

C -0.9576787617-1.1248796845 1.3340560693

N 0.1809063086 - 1.33386099771 .4509745228

H - 2.6084920629-2.2598517216-0.4399396584
H -2.42654356870.5777141964 2.793056202 H -4.8713100208 1.00113494162 .5374641233 H -5.0145343525 - $1.7994272895-0.7122857546$ H -6.3639126283 $0.2767008783-4.8613372081$ H -5.9711388763 1.4195781663 -3.5587854835 H -5.1396191111 -0.1458098082 -3.6452925939 H -7.6424089857 -1.8990214979-4.2765717491 H -8.0916870483 -2.2231344791 -2.5896894328 H -6.3835982107 -2.2808815901 -3.0916370169 H -8.3932642893 1.5349873724 -2.7900550738 H -8.8187361645 $0.4726843089-4.1439494525$ H -9.3059046452 $0.036640971-2.4932651556$ H -9.68778549872.4702350178 3.9279521932 H -8.1487368276 1.73896016474 .4188563415 H -8.1691435783 3.04172164123 .2220670801 H -10.7864500282 2.0442395569 1.1407516144 H -10.0605597372 $0.9200293275-0.02245309$ H -9.2907071172 2.4847156946 0.3120211406 H -9.1316158088 -1.1359078509 3.6577276883 H -10.7078642263 -0.47610335383.1913295897 H -9.7711204223 -1.4417938773 2.0303245274 


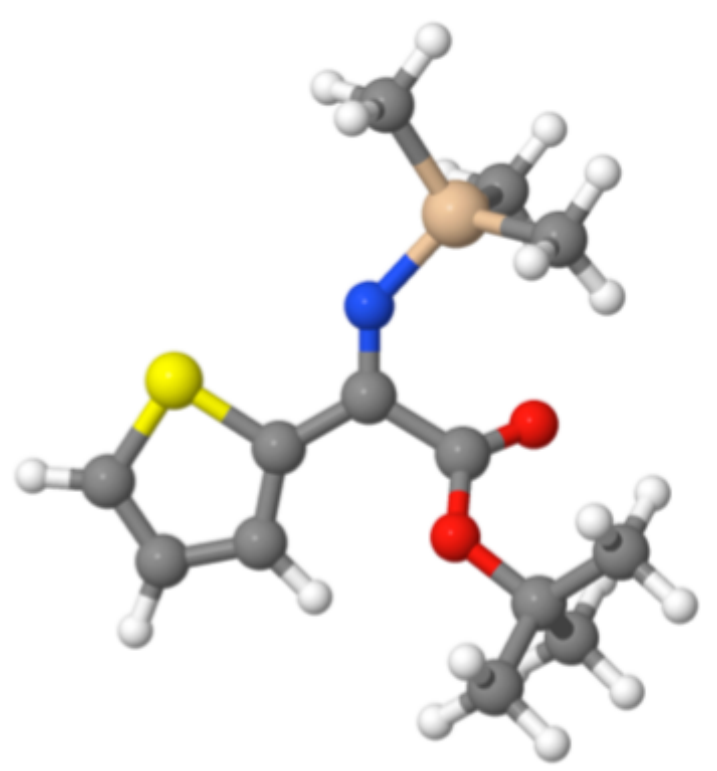

$\begin{array}{llll}\underline{\text { Atom }} & \underline{\mathbf{X}} & \underline{\mathbf{Y}} & \underline{\mathbf{Z}}\end{array}$

C -4.1841557225 -1.0997595894 -0.4382544811

C - $2.753338806-0.7759323076-0.4845941107$

C - 2.14728481610 .05242178650 .6625627434

O -1.0522833532 -0.19874312361.1236777718

O -2.9393808847 1.07020363421 .0260378926

C - 2.5372252662 .04827403142 .0691399135

C -3.73486073372.9994683032 2.1081175564

C - 2.35754233041 .331751253 .4105076519

C - 1.2705196762 .78633273131 .6268254032

N -2.0272811232 -1.2103054551 -1.4359254258

Si - $0.3207752603-1.157105797-1.8861023657$

C $0.50761827880 .5280864496-1.6429776991$

C $0.5722614378-2.5120728381-0.9222478722$

C $-0.3076617959-1.5561617246-3.7315871308$

C -5.1575108227-0.8238370285 0.5009551735

C -6.4249740471-1.3785489522 0.1761986582

C - $6.4040527838-2.071175087-1.0071315943$

S -4.8405896654 -2.0672749428 -1.7449542732

H -3.55847479 3.79199004992 .8428942601

H -3.89346735913.4624352551 1.1291318385
H -4.6488604029 2.4661729792 2.3889186252 H -2.16856229462.0729925154 4.1951662453

H - 1.51829729290 .63512640213 .3794770024 H -3.26623247620.78169220843.6790491149 H -1.4092775717 3.22169221210.6315397097 H -1.06397309393.6024168545 2.3283466404 H -0.4071973668 2.1198177844 1.6048400617 H $1.49953596650 .5226273453-2.1130092123$ H -0.0706553245 $1.3307223243-2.1171758002$ H $0.63538252280 .7750714447-0.5855064311$ H $1.6164469688-2.5979713465$-1.2481001256 H 0.0935734168 -3.486056544 -1.0749151253 H $0.5614114524-2.28899896040 .1490120145$ H - $0.8809785147-0.8158090303-4.3023505927$ H 0.7138906356 -1.5667755242 -4.1320532034 H - $0.7558298897-2.5377681108-3.923234854$ H -4.9680638282 -0.2356369278 1.3885486629 H -7.3101278773 -1.26507442370.7928511002 H -7.2274555101 -2.584453848 -1.4871207427 


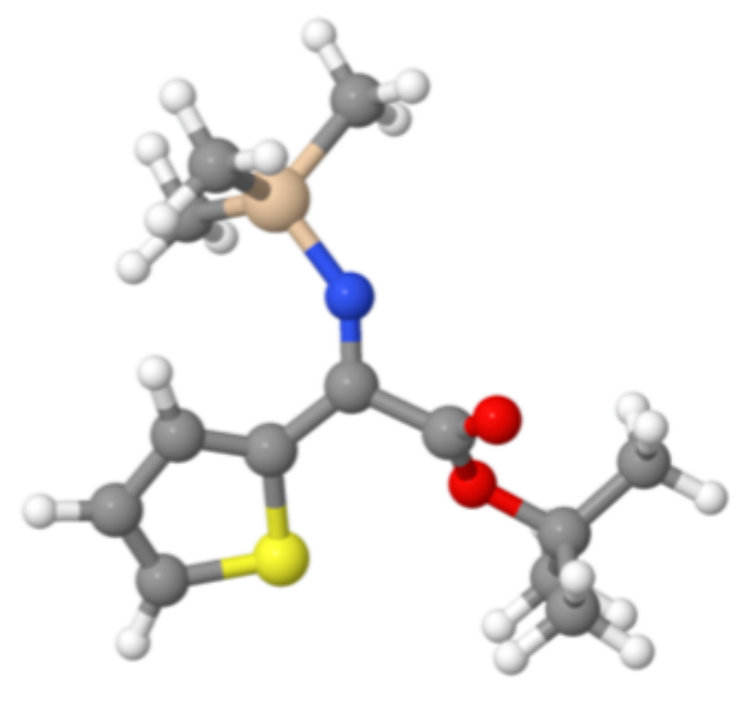

$\begin{array}{llll}\text { Atom } & \underline{\mathbf{X}} & \underline{\mathbf{Y}} & \underline{\mathbf{Z}}\end{array}$

C - $3.2354576850 .2236857484-1.2547108809$

C - $-1.98412220090 .24684403-0.4633124408$

C - 1.87742826191 .2870068040 .6619130235

O - 0.99901575312 .11566477580 .7187644066

O -2.86370682131.09825688261.5590323903

C - 2.98140374171 .93194369472 .780829823

C - 4.21893028511 .34990385693 .466258084

C - 1.73427982131 .74220318523 .64948631

C - 3.2055452683 .39548606432 .3898553214

N - $0.9474373835-0.4586819947-0.651880888$

Si - $0.3463289513-1.8295765518-1.5591884715$

C $0.5055707522-1.1568081319-3.1085696171$

C $0.9361690725-2.6459630706-0.4429813782$

C - $1.6525165368-3.1275880454-2.006202837$

C - $-3.3380195012-0.0577206501-2.6013213088$

C - $4.65973528890 .0468295177-3.1107394194$

C - $5.56316890210 .4123626899-2.1473166592$

S - $4.81286640510 .6466331949-0.608394859$

H - 4.4083539011 .878575184 .4064667898

H -5.101930417 1.4519640197 2.8274252101
H -4.07444360530.2879077795 3.6888100079 H - 1.8755426692 .2584698484 .6057688585 H -0.8459246578 2.14541393013.1609217734 H - 1.57265727270 .67905486653 .8574324138 H -4.0697846398 3.48562519981 .7230195735 H -3.409183932 3.98503558923 .2909985021 H - 2.3283222543 .81070341611 .891181376 H 1.0414396974 -1.961201002 -3.6279063315 H - $0.1985649419-0.7150335647-3.8230989637$ H $1.2365613547-0.3851336336-2.8428270928$ H $1.406651078-3.5062075462-0.9353425328$ H $0.4816479644-3.00382422170 .4884701789$ H $1.7241802152-1.9341013077-0.1734809358$ H - $2.4021663752-2.7622307825-2.7145847501$ H - $1.1655020756-4.0039195556-2.4534388615$ H - 2.185008027 -3.4721204797-1.1115503318 H - 2.4752725276-0.2950865657-3.2117963505 H - $-4.9251464488-0.1340643653-4.146606966$ H -6.6312845824 $0.5509911959-2.2545571661$ 


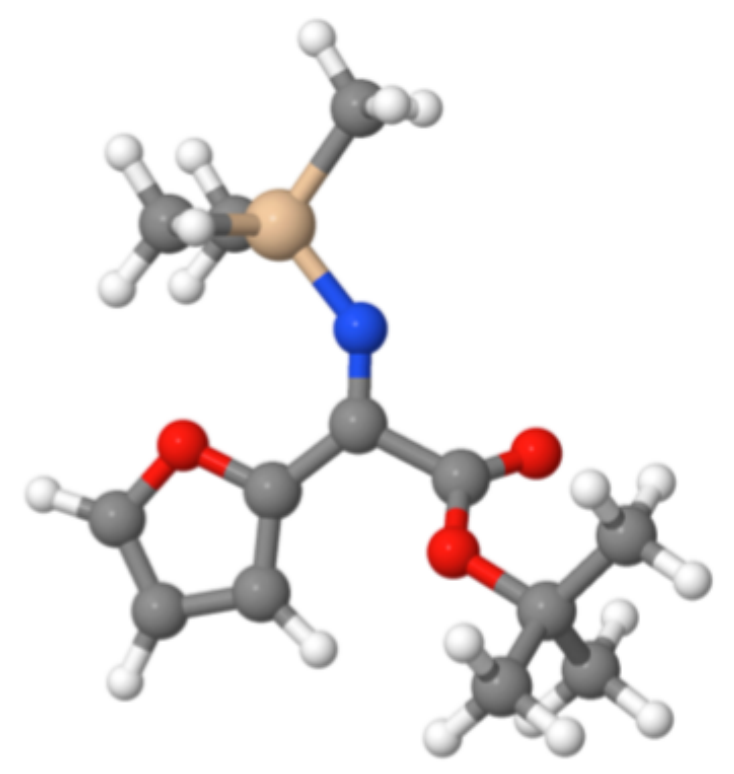

$\underline{\text { Atom }} \underline{\underline{\mathbf{X}}} \quad \underline{\mathbf{Y}} \quad \underline{\mathbf{Z}}$

C - $2.4289146843-0.7691602774-1.2036429639$

C - $2.01374172010 .2745264438-0.2624001887$

C - $0.50814336260 .593417857-0.2268700797$

O - $0.07666774521 .7199827911-0.3082345911$ O $0.2174879851-0.52807932-0.047060349$

C $1.6860135907-0.47779335560 .1452056321$

C $2.0462258062-1.95121298150 .346665946$

C $2.35954749770 .0851375629-1.1102954943$

C 2.01408325520 .33946142691 .3986501129

N - 2.74230938180 .97493222780 .504628963

Si -4.4296624971.17960047110.9465664035

C -4.4396881064 2.50017094562.2935129886

C -5.4230933944 $1.8097051339-0.535081296$

C -5.1607745097-0.4156608223 1.6562453351

C - $1.7487170128-1.5766229304-2.0842892813$

C - $2.7236462707-2.3577544393-2.7701378694$

C -3.931911132 -1.9769408329-2.2643527943

O -3.7748751909-1.0174700572 -1.3184388313

H $3.1238961619-2.05479140670 .5118975931$

H $1.5207000199-2.36249576841 .2142622125$
H $1.7737887271-2.5433584273-0.5332431229$ H $3.44796826870 .0215459047-0.99905219$ H $2.08460371011 .128232794-1.273174339$ H 2.0777758012 - 0.4990641153 -1.9937327842 H $1.4732700298-0.05733432272 .2645257807$ H 3.08766453560 .27056057191 .60738656 H 1.74928955281 .38972754461 .268334005 H -5.4580772128 2.7214143858 2.6372165318 H -3.8540022262 2.1805460195 3.1634567607 H -3.99760834973.4333659902 1.9258719455 H -6.4450557495 $2.0667189453-0.2284704024$ H -5.4829531703 $1.0622075499-1.331756902$ H -4.9674055745 2.7148238712 -0.9532888017 H - $4.5554816844-0.78719076512 .4916849711$ H -6.172091005 -0.2319501995 2.0409946847 H -5.2207617243 -1.2078460509 0.9041142687 H -0.6776970279 - $1.611091367-2.2089194976$ H - $2.5505531339-3.1034374625-3.5333457017$ H -4.9498130757 -2.2778335353 -2.4619472147 


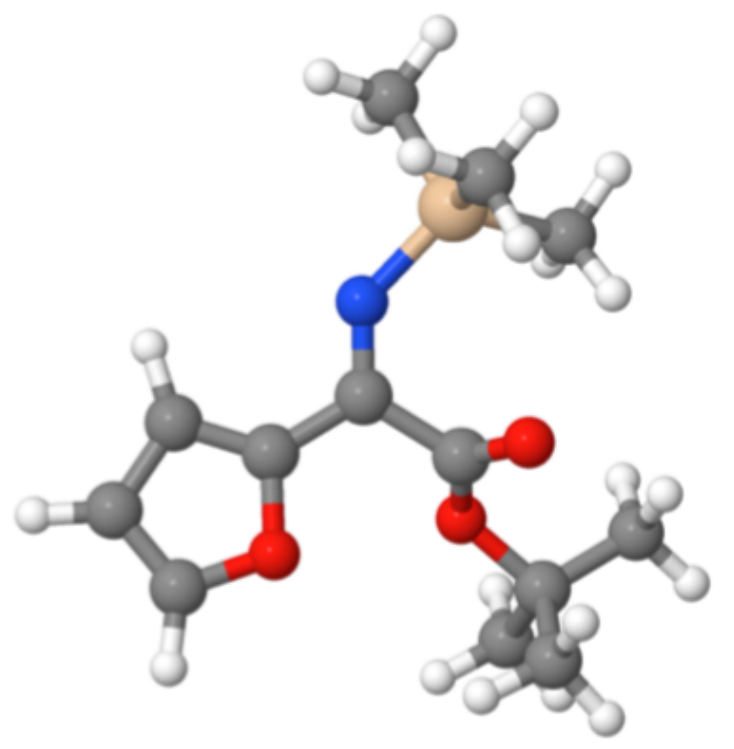

$\begin{array}{llll}\text { Atom } & \underline{\mathbf{x}} & \underline{\mathbf{Y}} & \underline{\mathbf{Z}}\end{array}$

C -3.3868550227-1.4054322143 -0.5364213551

C - $2.6581392935-0.27500898180 .0389138094$

C -1.1456087372 -0.4512199383 0.2446799321

O -0.6059523212 -0.2425058715 1.3128060819

O -0.5498158345 -0.8069554548 -0.8972864876

C $0.8990841369-1.1106615674-0.9735890574$

C $1.0773605886-1.4925503018-2.4442191459$

C $1.71703648710 .1365157701-0.6270241293$

C $1.2164146831-2.294306359-0.0551840698$

N-3.2827387811 0.78232791950.373781415

Si -2.8328356767 2.3119565777 1.1281104997

C - 4.14327218943 .54131422150 .5486495835

C -2.9432422502 2.05946592042.9953133567

C - 1.12928919872 .97722280150 .6380574767

C -4.6983502049-1.5433196763-0.9159075158

C - $4.8556434481-2.8868123798-1.3612156466$

C -3.6326641488 -3.478403044 -1.2165601592

O -2.7288197717 - 2.5983678873 -0.720063243

H 2.1223315649 -1.7556951796 -2.6391428044

H $0.4476760358-2.3509197086-2.6982907956$
H $0.8020043461-0.6579381595-3.0969172355$ H $2.7769197956-0.058016902-0.8269915139$ H 1.6039917890 .40678555740 .4239830881 H 1.4048490020 .9838515322 - 1.2467624527 H 0.5600785946 -3.1396373974 -0.2868836149 H $2.2536157529-2.6110522625$-0.2123770797 H 1.0892761638 -2.0266246574 0.9953394929 H -3.9929414906 4.52845373711 .003426306 H -4.1151479671 $3.6702603617-0.5400578815$ H -5.1487533827 3.19619452420 .8149193125 H -2.7546701908 2.999265099 3.5291443 H -2.2018297966 1.3235698854 3.3238888908 H -3.9352143598 1.69897987883 .290082344 H -1.0075472912 $3.012814312-0.4516488653$ H -1.00746190494.00192042281.012196337 H -0.32091011472.3680379009 1.0523263554 H -5.4432501497-0.7627413485 -0.8708167234 H -5.7546137069 -3.3539271351 -1.7386192858 H -3.2604047065 -4.4725979955 -1.4136295193 


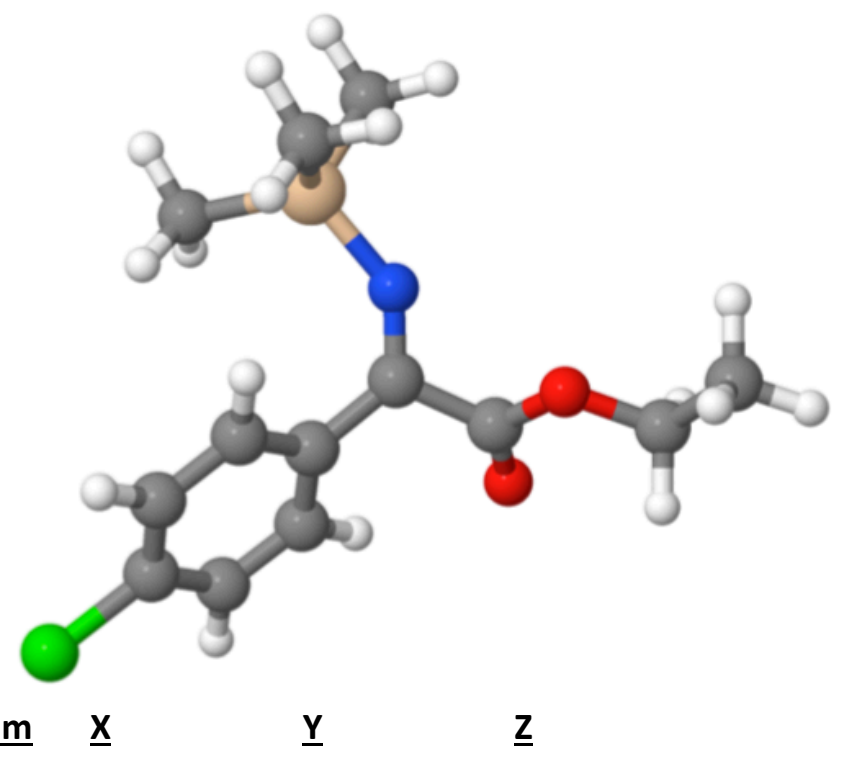

\begin{abstract}
$\begin{array}{llll}\text { Atom } & \underline{\mathbf{X}} & \underline{\mathbf{Y}}\end{array}$
\end{abstract}
C - $2.8886451069-0.77633180940 .7166949795$

C - 2.24838757770 .47272326750 .1915112858

C - 1.67500565141 .42843380641 .2412101374

O -0.9482146603 1.07545527652 .1501855277

O -2.03839889312.69589427831.0140749631

C - 1.48179038653 .68479770191 .9155031183

C -2.0514173965.0319405789 1.5150592468

N - $2.12248923250 .8203763467-1.020891848$

Si -2.3065579308 $0.1897453386-2.6508074156$

C - $0.78101780670 .803329828-3.5752301331$

C - $2.3942244621-1.6939481823-2.8240048215$

C -3.8613254067 $1.0010562822-3.3567140751$

C - $2.330583321-1.53081228681 .7621641764$

C - $2.9553000177-2.69264415572 .2118773077$

C -4.1598024761 -3.0907194199 1.6332962974

C - $-4.7487609572-2.3458235110 .6118137898$

C -4.1055819605 -1.1971942222 0.1580698167

Cl -4.9566058416 -4.5477525009 2.2073455443
H - 1.74411514173 .41168397382 .9426692554

H - 0.3906915913 .65620586651 .8323868067

H -1.6513640827 5.81326402472 .1704935198

H - 1.78494674225 .27642090990 .4821060122

H -3.1427450347 5.03581227651 .6000272631

H -0.8141457772 $0.5124451474-4.6325353855$

H -0.7086977114 1.8951623485 -3.5235994525

H $0.13913910890 .3890578313-3.1464255609$

H - 2.3434404183 -1.9684535458 -3.885776802

H -3.3133980682 -2.1212245973 -2.4115360649

H - $1.5500928757-2.1802599311-2.3207149234$

H -3.8228402461 2.0892022934-3.2365893409

H -3.9515563782 $0.7838102608-4.4282725164$

H -4.7760736071 $0.6429084156-2.8699679724$

H -1.4042942929 -1.2046578852 2.2189619817

H -2.5134096023 -3.2827196722 3.0077197619

H -5.6963313962 -2.65772017 0.1857297251

H -4.5685040577 -0.6019611635 -0.6231652046 


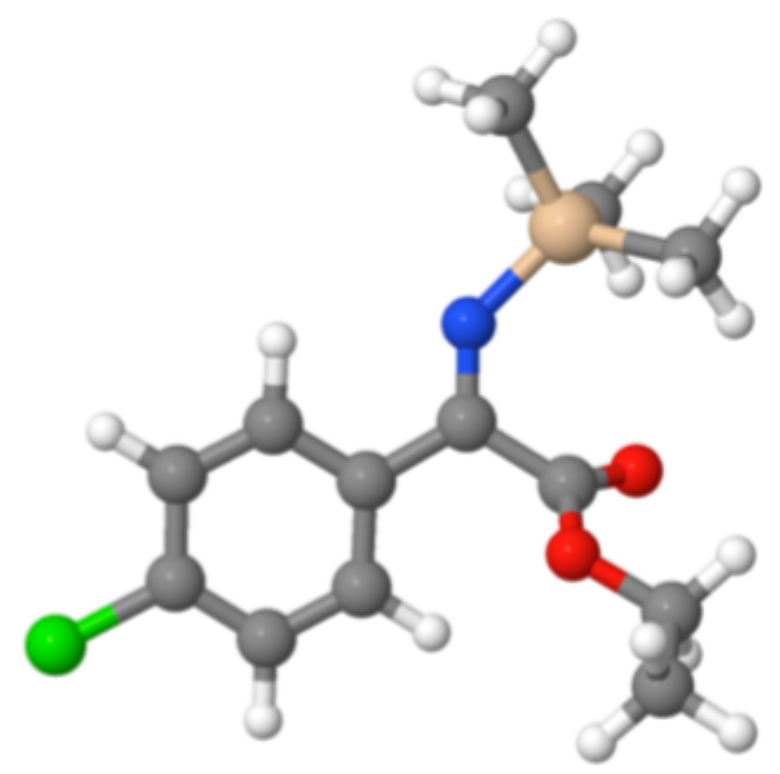

$\begin{array}{llll}\text { Atom } & \underline{\mathbf{X}} & \underline{\mathbf{Y}} & \underline{\mathbf{Z}}\end{array}$

C - $2.5057845883-1.70612962340 .0363374732$

C -1.646575673-0.5062161856-0.1862744955

C - 1.11596270210 .24532037421 .0399472793

O 0.05474172280 .51593690281 .2073678442

O -2.10489061370.6260059953 1.868635273

C -1.7069672651 1.43010172023.0112768706

C - 2.96360369111 .7688434023 .7891194369

N -1.3374577647 -0.1259932588 -1.3584760007

Si -0.3315071805 1.1530995059 -2.0525594874

C -1.0647148523 1.4597627176 -3.7643982378

C - $0.3383708512 .7877773622-1.097098258$

C $1.41457375160 .4526097962-2.1883991531$

C -3.1241146844 -2.3077006682-1.0723129834

C -3.904175385 -3.448207634-0.9284831973

C -4.0627502466 -4.0070134388 0.3420135801

C -3.4552633201 -3.4379700566 1.4592470501

C - $2.68298033-2.28845914011 .3004205148$

Cl -5.0440415916 -5.451427618 0.5332894248
H -0.9902217117 0.85709692393 .6078506244 H -1.1936098762 2.32358382372.6430640397 H - 2.70469275632 .38128214814 .6596158366 H -3.66799152462.331558322 3.1686396932 H -3.4640732179 0.86184255394 .1427260238 H -0.4863510406 2.2118368508 -4.3153906227 H - $1.07416304180 .5392793009-4.3589929927$ H -2.0978298722 1.8214223086 -3.6967686724 H $0.1562567953 .5647554284-1.6940208435$ H $0.19084912082 .7062443152-0.1434555499$ H -1.3592768729 $3.1358271016-0.8961034709$ H $1.4223433801-0.4891250734-2.7485143587$ H 2.07878220651 .1563460738 -2.7052522743 H 1.82684312810 .2609668122 -1.192137263 H -2.9745177777 -1.8596753565 -2.0488998659 H - 4.3850204321 -3.9050647694 -1.7869352415 H -3.5848963335 -3.8871349617 2.4379927611 H -2.2207529082 -1.8486069548 2.1771472433 


\section{$\begin{array}{llll}\text { Atom } & \underline{\mathbf{X}} & \underline{\mathbf{Y}} & \underline{\mathbf{Z}}\end{array}$}

C -1.6069619122 -0.08273637930.1422386295

C - $1.1362791748-1.40174831860 .038135973$

C - $2.019942689-2.4229532224-0.3331505115$

C -3.357299527-2.1242226287-0.5950116552

C -3.8478452714-0.8162480629-0.4655665083

C -2.9419095197 $0.1981617093-0.1008304266$

o $0.1864211111-1.57850733280 .3065611519$

C $0.7278003008-2.88779621380 .2056195469$

C -5.2736119213 - $0.460534379-0.7273297589$

C -5.9415891564-1.1702245327-1.9071466031

O $-6.5272025379-0.3033923286-2.74457863$

O -5.96776612 -2.3781374721-2.0475111628

C -7.2507446556-0.8885588219-3.8539155871

C -7.7840821274 $0.2524829161-4.6988398236$

N -6.0032336911 $0.3583946218-0.0871165898$

Si -6.0165655441 1.2770784108 1.4071315944

C -7.78817441391.13851116542.0436557776

C - 4.84962625550 .67078296032 .7710027912

C -5.6435174015 3.075618050 .9552941712

H -0.90320859850.70035710320.4063905115

H -1.6807040563 -3.4483848869 -0.4245375982
H -4.0337928542 -2.9163604947 -0.8929870126 H -3.2891207528 1.225130859-0.0410830745 H $1.7848559474-2.79340039590 .4600483133$ H $0.2451758773-3.57832025680 .9092190995$ H $0.6332988694-3.2849636297-0.8132778$ H - $6.5710954539-1.537441088-4.4158167807$ H -8.0538114152 -1.5162260761 -3.4544300485 H -8.3442749747 - $0.1474635159-5.5511703513$ H -8.4528722325 $0.8916397877-4.1139380206$ H -6.9658090101 $0.8700165922-5.0828190601$ H -7.9276520751 1.71694983562 .9655054387 H -8.4993346148 1.50904458531 .2971710282 H -8.05119953810.09679085172.2626935095 H -5.0556613515 1.21305536763.7031727781 H -3.7926759327 0.81212392982 .5257123115 H -5.0005948289 -0.3963110975 2.9738691276 H -6.2897869147 3.41472426050 .1381628725 H -5.8217935936 3.73001834141 .8177173069 H -4.60329298973.22062078660.6411730703 


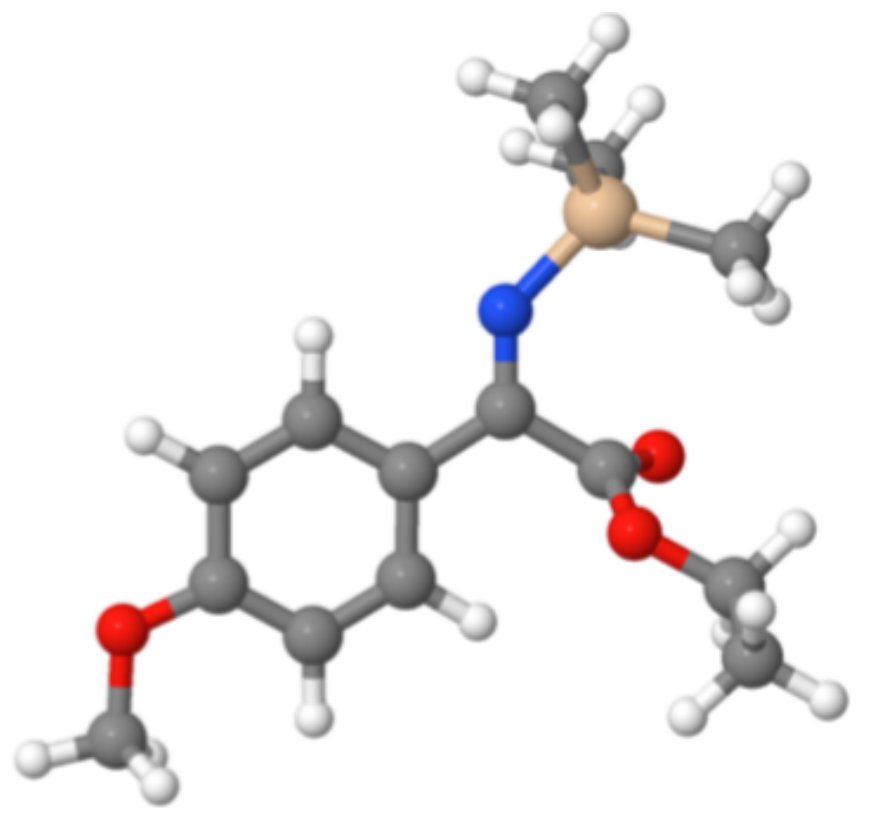

$\begin{array}{llll}\text { Atom } & \underline{\mathbf{X}} & \underline{\mathbf{Y}} & \underline{\mathbf{Z}}\end{array}$

C - $2.632043374-0.7115691579-0.6656745601$

C - $2.0891671444-0.74825876770 .6241559341$

C - $2.9231612354-0.53057313161 .7360984569$

C -4.2713789194-0.28490525761.5554668451

C -4.8368599734-0.24023978750.2652084692

C -3.9939205488 -0.4575573829-0.832067164

C -6.2947401882-0.0042529121 0.1206787227

C -6.8660213096 $0.0644671671-1.2992170387$

O -6.3975800849 $1.1288449201-1.9792887148$

O -7.686579852 -0.7146796056-1.7366366832

C -6.9530606609 $1.3335570216-3.304466123$

C -6.2942888207 $2.5689269961-3.8872957167$

N -7.06429880140.1026181179 1.1294079724

Si -8.79371965930.3280267106 1.3750727093

C -8.9335184831 1.35462927622 .9532458886

C -9.7081729293 $1.2369665238-0.0142717226$

C -9.5280350204-1.3917206161 1.6308039994

O - $0.7796955469-0.98413978380 .9073602845$

C $0.1143782952-1.2184751125-0.1709617594$

H -2.0115673604 -0.8767167183-1.5387666779

H -2.4813927935 -0.5632764163 2.7272222217
H -4.9250361467 -0.1227560318 2.4060452582 H -4.3919357577 -0.4253753491 -1.8410443688 H -6.7635570862 0.4390434005 -3.9062123968 H -8.0375430396 1.44793818 -3.212276766 H -6.6899725667 2.7610598122 -4.8905981538 H -6.4908796764 $3.4474281074-3.2647774023$ H -5.2102911793 2.4367419436 -3.9635103379 H -9.9823570406 1.51017298283 .2352420783 H -8.42803263170.858938453 3.7896313132 H -8.4741470618 2.34241110382.827170097 H -10.7322697592 1.46983300310 .3045254146 H -9.7663528223 $0.6330318177-0.9246573532$ H -9.2216547052 2.1881280518 -0.2644043131 H -9.0175705908 -1.9235314537 2.4414118217 H -10.593326103 -1.3302362767 1.885850894 H -9.4309547932 -1.9910407058 0.7188533911 H 1.0927490444 -1.3839010349 0.283281539 H - $0.1744993232-2.1073532416-0.7465703313$ H $0.1679446497-0.3530308456-0.8440817275$ 


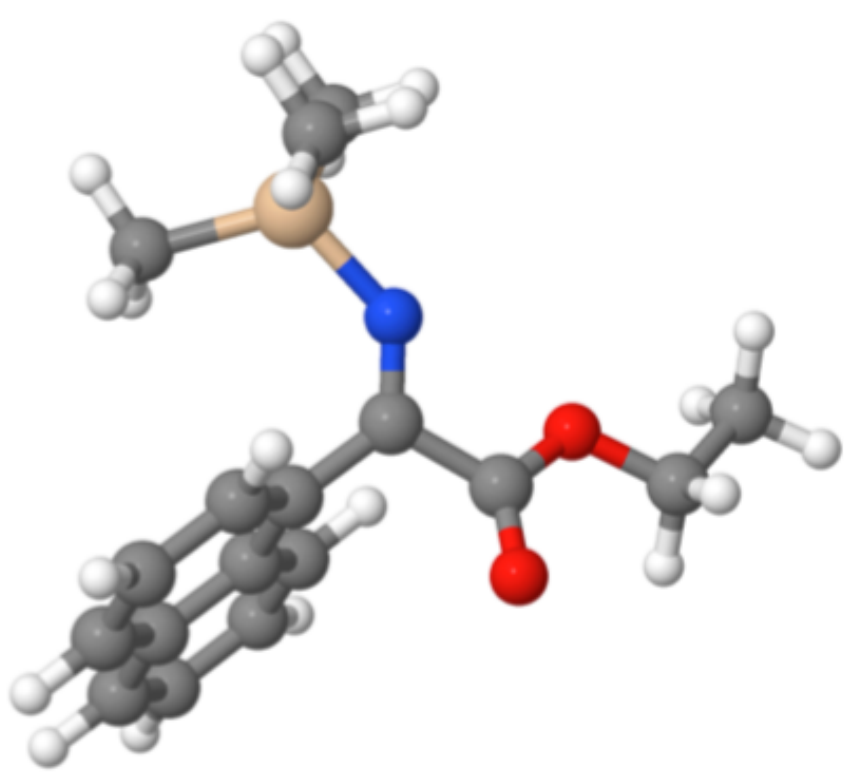
Atom $\underline{\mathbf{X}}$
$\underline{\mathbf{Y}}$
$\underline{\mathbf{z}}$
C -6.9625768849-0.1606776183 3.2078559537
C -7.8492577403 -1.1271119092 3.7538839527
C -8.88777477244-1.6303503506 3.0059392582
C -9.0864034982 -1.1879432393 1.6772622314
C -8.2528587542-0.245495085 1.1086554435
C -7.1633184144 0.2945591021 .8630150781
C - $8.50861790850 .2169384623-0.2996953133$
C - $9.05663442651 .644306775-0.3909140669$
O -8.7154855067 2.2542335382 -1.5364494018
O -9.73068421442.1483212658 0.4833870228
C - $9.24293884293 .5900764429-1.7135637164$
C -8.7282613788 $4.1086663441-3.0427260659$
N -8.3931653041 -0.4593818841-1.3647592433
Si -7.8279485783 -2.0789573937-1.7854036611
C -6.6941379534-1.8051335671-3.2686569544
C -6.25745691621.251216352 1.3273091236
C - $6.874458811-3.0287579434-0.4547785556$
C -5.2165661261 1.74205359132 .0838897248
C -5.0235594105 1.29661685373.413203783
C -5.87701747870.3648959306 3.9585784643
C - $9.3714960255-3.0383443488-2.299651047$
H -7.6923035114 -1.4615222952 4.7766075573

H -9.5658995503 -2.3644955511 3.4320119252

H -9.9218334502 -1.577498559 1.1017258156

H -10.3363451638 $3.5413273649-1.6852084356$

H -8.9187129653 4.2113396014-0.8721333126

H -9.1091053077 $5.1206416407-3.2190260513$

H -7.6341788739 $4.1453300789-3.0511632633$

H -9.057247471 $3.4662865309-3.8655054984$

H -6.328123974 -2.7602896136 -3.665286304

H -7.2211927263 -1.2801461665-4.0725347727

H -5.8194277712 - 1.2029904349 -2.9959077887

H -6.3863396991 1.59195992470 .3036197781

H -6.4584830434 -3.9486571721 -0.8865391573

H -7.5042597103 -3.3115169180.3944162203

H -6.0360040238 -2.442264087-0.0614651724

H -4.53605674972.4741194661.6576703612

H -4.1975983885 1.6902515413 .999239146

H -5.7311191975 0.01373855964 .9774721493

H -9.9311896961 -2.4985474999-3.0712479208

H -9.0984399566 -4.0203894549-2.7052743894

H -10.045940872 -3.2067922743 -1.451949897 


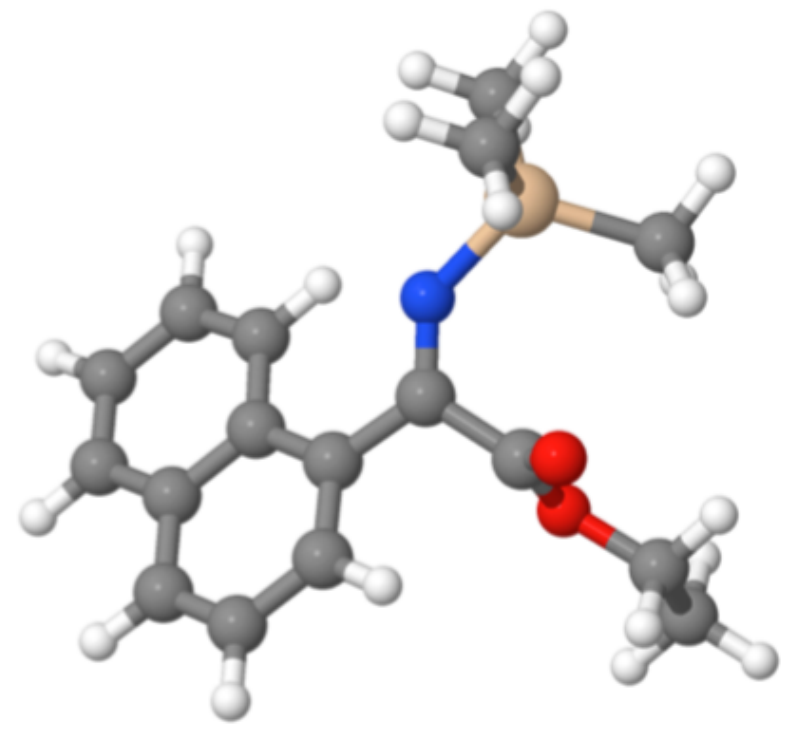

$\underline{\underline{\text { Atom }}} \underline{\underline{\mathbf{X}}} \quad \underline{\mathbf{Y}} \quad \underline{\mathbf{Z}}$

C -6.1608451457-1.9822525152 2.6453698848

C -7.1060150205-1.7241018118 3.6728744908

C -8.3079482272 -1.1218107712 3.3877050309

C -8.6072536298-0.7528968202 2.0606122906

C -7.7318181972 -0.9984229861 1.0113748026

C -6.464628276-1.6286161051 1.2856299981

C -8.1885671682 -0.6111269206 -0.3545825631

C - $9.2020359440 .5408166387-0.3978061385$

O -8.621834097 1.7098560097-0.0770986706

O -10.3641527972 $0.4171806113-0.7262992214$

C - $9.47089348572 .8851313484-0.1378343081$

C - 8.62181058474 .07886372820 .2539275283

N -7.8227976748 -1.1868779542-1.4275456835

Si -8.2356934383 -1.0170332419-3.1362342247

C -9.5424201507-2.3293750718 -3.4936275164

C -8.8460289769 $0.6941787392-3.6737138014$

C -6.6324681411-1.4008605869 -4.0571257921

C -5.4788817349 -1.8930334409 0.295397524

C - $-4.2742090794-2.47416980820 .62858471$

C -3.9838228968-2.8302503837 1.9652886337

C - $4.9113666108-2.58599902312 .9505002039$

H -6.8588853615 -2.0107554072 4.6924077408
H -9.0308743462 -0.9282131504 4.1749440193 H -9.569858188 -0.2921048842 1.8564430595 H -9.8698313655 2.97574588104 -1.1528542536 H -10.3174115306 2.738544463150.5406274203 H -9.228326044 4.99060910070 .2231955221 H -8.22541496813.96133393561.2673483179 H -7.7791486569 $4.2018185966-0.4337487465$ H - $9.778144518-2.3650562413-4.564484981$ H -9.1967557335 -3.3239464193 -3.1908586846 H -10.4685384488 -2.1127545768 -2.9497792424 H -8.9140373433 $0.7347304422-4.7684057085$ H -8.1559431797 $1.4877617557-3.3611792212$ H -9.8354085197 $0.9217558471-3.2654984212$ H -6.2514219914 -2.3908740975 -3.7822349588 H -6.784993471 -1.3873086376 -5.1434694862 H -5.8511864472 -0.6668691812 -3.8249934728 H -5.6986166474 -1.6439302947 -0.7333627199 H -3.5382222755 -2.6629847038-0.1486197473 H -3.0308419974 -3.2914347454 2.2102946633 H -4.7016066892 -2.8474574151 3.9851007229 


\section{References}

1. Infante, R.; Nieto, J.; Andrés, C. Chem. Eur. J. 2012, 18, 4375.

2. Enders, D.; Rembiak, A.; Stöckel, B. A. Adv. Synth. Catal. 2013, 355, 1937.

3. Igarashi, T.; Tayama, E.; Iwamoto, H.; Hasegawa, E. Tetrahedron Lett. 2013, 54, 6874.

4. Liu, L.; Du, L.; Zhang-Negrerie, D.; Du, Y.; Zhao, K. Org. Lett. 2014, 16, 5772.

5. Xie, Y.; Liu, J.; Huang, Y.; Yao, L. Tetrahedron Lett. 2015, 56, 3793.

6. Khan, S.; Ahmed, Q. N. Eur. J. Org. Chem. 2016, 5377.

7. Matsuda, Y.; Tanimoto, S.; Okamoto, T.; Ali, S. M. J. Chem. Soc., Perkin Trans. 1 1989, 279.

8. Deng, Q.-H.; Xu, H.-W.; Yuen, A. W.-H.; Xu, Z.-J.; Che, C.-M. Org. Lett. 2008, 10, 1529.

9. Almansa, R.; Guijarro, D.; Yus, M. Tetrahedron: Asymmetry 2008, 19, 2484.

10. Shimizu, M.; Niwa, Y.; Nagai, T.; Hachiya, I. Heterocycles 2007, 72, 127.

11. Frauenlob, R.; García, C.; Bradshaw, G. A.; Burke, H. M.; Bergin, E. J. Org. Chem. 2012, 77, 4445.

12. Tayama, E.; Sato, R.; Takedachi, K.; Iwamoto, H.; Hasegawa, E. Tetrahedron 2012, 68, 4710.

13. Dickstein, J. S.; Fennie, M. W.; Norman, A. L.; Paulose, B. J.; Kozlowski, M. C. J. Am. Chem. Soc. 2008, 130, 15794.

14. Laufer, R.; Ng, G.; Liu, Y.; Patel, N. K. B.; Edwards, L. G.; Lang, Y.; Li, S.-W.; Feher, M.; Awrey, D. E.; Leung, G.; Beletskaya, I.; Plotnikova, O.; Mason, J. M.; Hodgson, R.; Wei, X.; Mao, G.; Luo, X.; Huang, P.; Green, E.; Kiarash, R.; Lin, D. C.-C.; Harris-Brandts, M.; Ban, F.; Nadeem, V.; Mak, T. W.; Pan, G. J.; Qiu, W.; Chirgadze, N. Y.; Pauls, H. W. Bioorg. Med. Chem. 2014, 22, 4968.

15. Miura, T.; Morimoto, M.; Murakami, M. Org. Lett. 2012, 14, 5214.

16. Gaussian 03, Revision C.02, Frisch, M. J.; Trucks, G. W.; Schlegel, H. B.; Scuseria, G. E.; Robb, M. A.; Cheeseman, J. R.; Montgomery, Jr., J. A.; Vreven, T.; Kudin, K. N.; Burant, J. C.; Millam, J. M.; Iyengar, S. S.; Tomasi, J.; Barone, V.; Mennucci, B.; Cossi, M.; Scalmani, G.; Rega, N.; Petersson, G. A.; Nakatsuji, H.; Hada, M.; Ehara, M.; Toyota, K.; Fukuda, R.; Hasegawa, J.; Ishida, M.; Nakajima, T.; Honda, Y.; Kitao, O.; Nakai, H.; Klene, M.; Li, X.: Knox, J. E.; Hratchian, H. P.; Cross, J. B.; Bakken, V.; Adamo, C.; Jaramillo, J.; Gomperts, R.; Stratmann, R. E.; Yazyev, O.; Austin, A. J.; Cammi, R.; Pomelli, C.; Ochterski, J. W.; Ayala, P. Y.; Morokuma, K.; Voth, G. A.; Salvador, P.; Dannenberg, J. J.; Zakrzewski, V. G.; Dapprich, S. ; Daniels, A. D.; Strain, M. C.; Farkas, O.; Malick, D. K.; Rabuck, A. D.; Raghavachari, K.; Foresman, J. B.; Ortiz, J. V.; Cui, Q.; Baboul, A. G.; Clifford, S.; Cioslowski, J.; Stefanov, B. B.; Liu, G.; Liashenko, A.; Piskorz, P.; Komaromi, I.; Martin, R. L.; Fox, D. J.; Keith, T.; Al-Laham, M. A.; Peng, C. Y.; Nanayakkara, A.; Challacombe, M.P.; Gill, M. W.; Johnson, B.; Chen, W.; Wong, M. W.; Gonzalez, C.; Pople, J. A. Gaussian, Inc., Wallingford CT, 2004. 